Uniwersytet Przyrodniczy w Lublinie

\title{
Wybrane zagadnienia z zakresu ochrony i zagrożeń środowiska
}

Środowisko - Roślina - Zwierzę - Produkt 
Wybrane zagadnienia

z zakresu ochrony i zagrożeń środowiska 
Środowisko - Roślina - Zwierzę - Produkt 


\title{
Wybrane zagadnienia z zakresu ochrony i zagrożeń środowiska
}

\author{
pod redakcją \\ Marka Babicza \\ Bożeny Nowakowicz-Dębek
}


Recenzent

dr hab. inż. Beata Seremak, prof. ZUT

Opracowanie redakcyjne

Ewa Zawadzka-Mazurek

Projekt okładki

Jacek Pałyszka

\section{(c) $\underset{\mathrm{BY}}{\mathrm{N}} \odot$}

Ten utwór jest dostępny na licencji Creative Commons Uznanie autorstwa -

Użycie niekomercyjne - Bez utworów zależnych 4.0 Międzynarodowe.

ISBN 978-83-7259-338-2 on-line

DOI: $10.24326 /$ mon.2021.6

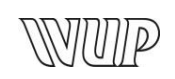

Wydawnictwo Uniwersytetu Przyrodniczego w Lublinie

ul. Akademicka 15, 20-950 Lublin

https://up.lublin.pl/nauka/wydawnictwo/

9,8 ark. wyd. 


\section{Spis treści}

Jakub Chalimoniuk, Gabriela Michta, Piotr Ostrowski, Natalia Kanadys,

Anita Gorczyca, Kamila Rybczyńska-Tkaczyk

Biodegradacja alkilofenoli przez mikroorganizmy

Biodegradation of alkylphenols by microorganisms

\section{Aleksander Chudy}

Rola elektromobilności w ograniczaniu emisji zanieczyszczeń powietrza

i gazów cieplarnianych

The role of electromobility in the mitigation of air pollution and greenhouse gas emissions

\section{Aleksandra Garbacz}

Zjawisko quorum sensing u bakterii

Quorum sensing phenomenon in bacteria

Damian Jaguszewski, Katarzyna Karpińska, Bożena Nowakowicz-Dębek

Natężenie oświetlenia w środowisku pracy nauczyciela języka angielskiego

Illumination intensity in the work environment of an English teacher

\section{Martyna Jarosz, Weronika Glowienka, Monika Stoma}

Ocena świadomości ekologicznej mieszkańców Lubelszczyzny

Evaluation of environmental awareness of the Lublin region inhabitants

Katarzyna Karpińska, Damian Jaguszewski, Gabriela Kosowska,

Bożena Nowakowicz-Dębek

Zagrożenie hałasem w środowisku pracy operatora ładowarki czołowej

Noise pollution in the working environment of the front-end loader operator

Dominika Kopiec, Karolina Kuzioła, Bożena Nowakowicz-Dębek

Identyfikacja zagrożeń $\mathrm{i}$ ich analiza w środowisku pracy piekarza

Identification of hazards and their analysis in the baker's work environment

Gabriela Kosowska, Katarzyna Karpińska, Damian Jaguszewski,

Bożena Nowakowicz-Dębek

Identyfikacja i analiza zagrożeń w małej gastronomii

Identification and hazard analysis in gastronomy

Gabriela Kosowska, Bożena Nowakowicz-Dębek, Lukasz Wlazło, Martyna Kasela,

Mateusz Ossowski

Zagrożenia chemiczne w trakcie pracy kosmetyczki

Chemical hazards during the work of the beautician

Bartlomiej Mistal, Anna Pecyna, Agnieszka Buczaj, Dżesika Stankiewicz

Organizacja ochrony przeciwpożarowej i zabezpieczenie przeciwpożarowe

na przykładzie domu pomocy społecznej

Organization of fire protection and prevention from fire risks based

on Social Care Center 
Piotr Ostrowski, Jakub Chalimoniuk, Natalia Kanadys, Gabriela Michta,

Kamila Rybczyńska-Tkaczyk

Perspektywy wykorzystania mikroorganizmów do biodegradacji cytostatyków

Prospects for using microorganisms for biodegradation of cytostatics

Wiktoria Polit, Wojciech Ospalek, Nina Mickiewicz, Agata Satowska, Agata Domagała, Lukasz Wlazło, Bożena Nowakowicz-Dębek

Wpływ ekspozycji na dźwięk na wzrost i rozmnażanie drożdży

Effects of sound exposition on yeast growth and proliferation

\section{Karolina Spólna, Sonia Pustelny}

Czy hybrydyzacja może być realnym zagrożeniem dla funkcjonowania populacji wierzby lapońskiej (Salix lapponum L.) na torfowiskach

Pojezierza Łęczyńsko-Włodawskiego?

Can hybridization be a real threat to the functioning of the Salix lapponum populations in the bogs of the Łęczyńsko-Włodawskie Lakeland?

\section{Kamila Talarek, Aleksandra Horbowicz, Marceli Romańczuk,}

\section{Malgorzata Marczak}

Charakterystyka wybranych mechanizmów regulacyjnych fizjologii bakterii

z uwzględnieniem ich wpływu na tworzenie biofilmów

Characteristics of selected regulatory mechanisms of bacterial physiology,

including their influence on the biofilm formation

\section{Urszula Waszczuk, Ewa Zapora}

Grzyby wielkoowocnikowe w ochronie środowiska naturalnego

Macromycetes in environmental protection 


\author{
Jakub Chalimoniuk ${ }^{1,4}$, Gabriela Michta ${ }^{1}$, Piotr Ostrowski ${ }^{1}$, Natalia Kanadys ${ }^{1}$, \\ Anita Gorczyca ${ }^{2}$, Kamila Rybczyńska-Tkaczyk ${ }^{3}$
}

\title{
Biodegradacja alkilofenoli przez mikroorganizmy
}

Biodegradation of alkylphenols by microorganisms

Na skutek działalności gospodarczej człowieka powstają ksenobiotyki, które mogą stanowić duże zagrożenie dla środowiska. Efektem ich oddziaływania na organizmy mogą być m.in. mutacje wywoływane przez cytostatyki oraz feminizacja lub obojnactwo (alkilofenole). Szczególnie niebezpieczną grupę zanieczyszczeń stanowią alkilofenole $\left(\mathrm{AP}_{\mathrm{s}}\right)$ i ich oksyetylaty $\left(\mathrm{APE}_{\mathrm{s}}\right)$ będące analogami hormonów u ludzi i zwierząt.

Celem niniejszej pracy było przybliżenie zagrożeń związanych z wpływem alkilofenoli na środowisko oraz przybliżenie możliwości ich biodegradacji przy wykorzystaniu mikroorganizmów ze szczególnym uwzględnieniem bakterii i grzybów.

\section{Charakterystyka alkilofenoli}

Alkilofenole $\left(\mathrm{AP}_{\mathrm{s}}\right)$ i ich oksyetylaty $\left(\mathrm{APE}_{\mathrm{s}}\right)$ zaliczane są do związków fenolowych [Szymański i Wyrwas 2010]. Należą one do niejonowych środków powierzchniowoczynnych znajdujących zastosowanie w produktach użytku domowego i przemysłowego. Ich aktywność związana jest $\mathrm{z}$ obecnością w łańcuchu bocznym alkilofenolu hydrofobowego i długiego łańcucha powtarzających się grup tlenku etylenu, które nadają tej cząsteczce charakter hydrofilowy. Jeden łańcuch zawiera od 1 do 100 powtarzających się grup, a im dłuższy jest łańcuch, tym związek lepiej rozpuszcza się w wodzie. Do grupy alkilowej najczęściej należy rozgałęziony łańcuch nonylowy, oktylowy lub dodecylowy [Nimrod i Benson 1996]. Związki te i produkty ich degradacji nie są produkowane naturalnie, a ich obecność w środowisku jest konsekwencją antropogenicznej działalności człowieka. Jedynie nieliczne alkalifenole spotykane są w warunkach naturalnych - przykładem są m.in. składniki ropy naftowej. $\mathrm{AP}_{\mathrm{s}}$ uzyskiwane są w procesie alkilowania fenolu przy użyciu alkenów otrzymywanych przez oligomeryzację. Z kolei $\mathrm{APE}_{\mathrm{s}}$ otrzymuje się $\mathrm{w}$ procesie poliaddycji tlenku etylenu do izomerycznych alkenów w obecności katalizatorów zasadowych [Szymański i Wyrwas 2010]. Alkilofenole są powszechnie wykrywane w ściekach przemysłowych i oczyszczalniach. Na skutek degradacji oksyetylatów w oczyszczalniach ścieków oraz w środowisku, generowane zostają APE

\footnotetext{
${ }^{1}$ Uniwersytet Przyrodniczy w Lublinie, Wydział Agrobioinżynierii, Studenckie Koło Naukowe Analityków Środowiska

${ }^{2}$ Uniwersytet Przyrodniczy w Lublinie, Wydział Agrobioinżynierii, Koło Naukowe Studentów Bioinżynierii i Biotechnologii „BioGen”

${ }^{3}$ Uniwersytet Przyrodniczy w Lublinie, Katedra Mikrobiologii Środowiskowej

4 chalimoniuk.jakub@gmail.com
} 
o krótszych łańcuchach oraz alkilofenole takie jak: nonylofenol (NP) i oktylofenol (OP), które charakteryzują się wyższą odpornością na degradację niż związki wyjściowe [Ying $\mathrm{i}$ in. 2002]. Wiele $\mathrm{AP}_{\mathrm{s}}$ jest mimetykami hormonów, przez co mogą one wpływać na dane receptory, hamując syntezę hormonów, a także oddziałując na dystrybucję hormonów w organizmie. Przykładem jest para-nonylofenol, analog 17ß-estradiolu, który wpływa negatywnie na sekrecję cytokinin przez łożysko, czego skutkiem mogą być poronienia. Wykazano również, że indukcja syntezy receptorów estrogenowych i progesteronowych w obecności tego związku, może mieć związek z rozwojem nowotworów [Wojcieszyńska i in. 2011]. Szczególną uwagę przyciągają etoksylany nonylofenolu, mające niekorzystny wpływ na środowisko. W wielu przeprowadzonych badaniach wykazano, że wysoce rozgałęziona grupa nonylowa i pierścień fenolowy nonylofenolu zawierający hydrofobową część NPE mogą jedynie w niewielkim stopniu ulegać biodegradacji. Uwagę zwraca również podwyższony poziom krótkołańcuchowych etoksylatów, które wykazują wyższą ostrą toksyczność dla organizmów wodnych niż etoksylaty o długich łańcuchach [Naylor i in. 1992]. Na dużą biokoncentrację $\mathrm{AP}_{\mathrm{s}}$ narażone są szczególnie organizmy wodne. Spowodowane jest to korzystnymi warunkami akumulacji substancji z roztworów, przez co zauważane mogą być silne efekty toksycznego działania tych związków przy niskich stężeniach w wodzie. W swoich badaniach Szymański i Wyrwas [2010] wykazali, że największą biokoncentracją $\mathrm{AP}_{\mathrm{s}}$ odznaczają się glony, małże, cierniki oraz ryby, z kolei najwyższą biokoncentrację $\mathrm{APE}_{\mathrm{s}}$ wykazywały glony, mięśnie kaczki krzyżówki oraz wątroby ryb. Ze względu na wzrost świadomości na temat szkodliwego wpływu tych związków na organizmy, wprowadzane są ograniczenie w produkcji i zużyciu tych związków. W Unii Europejskiej w 2003 r. wprowadzono drastyczne ograniczenia prawne dotyczące stosowania $\mathrm{AP}_{\mathrm{s}}$ i $\mathrm{APE}_{\mathrm{s}}$ [Directive 2008/105/EC]. Konwencjonalne metody oczyszczania ścieków polegające na mechaniczno-biologicznym oczyszczaniu przy wykorzystaniu osadu czynnego nie usuwają w pełni skutecznie związków biologicznie czynnych, jakimi są alkilofenole [Kamińska i in. 2016]. Alternatywą dla obecnie stosowanych metod jest wykorzystanie szczepów mikroorganizmów zdolnych do biodegradacji alkilofenoli.

\section{Biodegradacja przez bakterie}

Jednymi ze szczepów mikrobów, będących w stanie zdegradować związki należące do alkilofenoli - nonylofenole, są bakterie Gram-ujemne z rzędu Sphingomonadales. Wśród tego rzędu najwyższe odnotowane zdolności wykazują Sphingomonas sp. szczep TTNP3 oraz Sphingobium xenophagum szczep Bayram [Kolvenbach i Corvini 2012]. Zdolność do degradacji nonylofenolu posiadają również bakterie z rodzaju Pseudomonas i Citrobacter. Szczepy Pseudomonas putida i Citrobacter freundii należą do bakterii o wysokiej wydajności degradacji nonylofenolu. Odkryto, że w wyniku zastosowania substratu współmetabolicznego w hodowli danych szczepów zdolność degradacji zanieczyszczeń organicznych ulega ulepszeniu. W przypadku Pseudomonas putida zastosowanie peptonu, jako dodatkowego źródła węgla, potęgowało degradację nonylofenolu, a w przypadku Citrobacter freundii sprzyjało temu wykorzystanie ekstraktu wołowego, w przeciwieństwie do glukozy, która, stając się głównym źródłem węgla i energii, uniemożliwiała degradację nonylofenoli. Wykorzystanie dodatkowego źródła węgla pozwoliło osiągnąc 53\% degradację nonylofenolu [Xie i in. 2015]. 
Szlaki degradacji nonylofenolu u bakterii mogą być inicjowane przez rozpad ugrupowania fenolowego [Chakraborty i Dutta 2006] lub przez utlenianie łańcuchów alkilowych [Hao i in. 2010]. Pierścień aromatyczny może ulegać rozpadowi przez ipso-hydroksylację lub monohydroksylację na atomie węgla sąsiadującym z grupą hydroksylową, co skutkuje wytworzeniem alkilokatecholu [Tuan i in. 2011]. Zaangażowany jest w nią gen $\mathrm{mPH}$ [Corvini i in. 2004]. Trzecim sposobem jest dehydroksylacja pierścienia fenolowego.

Trudność w degradacji nonylofenolu wynika z czwartorzędowego atomu $\alpha$ węgla $\mathrm{w}$ rozgałęzionym łańcuchu alkilowym w jego budowie. Dlatego do prowadzenia badań związanych z biodegradacją nonylofelu jako podłoże wzrostu bakterii wykorzystywane są pojedyncze izomery, m.in. p353NP [Kolvenbach i Corvini 2012]. Do degradacji alkilofenoli wspomniane wcześniej szczepy wykorzystują mechanizm substytucji ipso typu II [Corvini i in. 2006] wiążący się z jednym ze sposobów rozkładu pierścienia aromatycznego. Mechanizm ten wykorzystywany jest zarówno w odniesieniu do nonylofenoli (NP), jak i bisnefolu A.

Szlaki degradacji u obu wymienionych szczepów bakterii obejmują ipso-hydroksylację NP jako pierwszy krok. Główny szlak opiera się na wprowadzeniu jednego atomu tlenu cząsteczkowego przez monooksygenazę wyłącznie w obecności NADPH i FAD jako kofaktorów w bisfenolu A. W wyniku substytucji ipso II typu podstawnik alkilowy zostawia cząsteczkę chinolu w postaci karbokationu, a hydrochinon (HQ) jest związkiem pośrednim degradacji. W wyniku tego dochodzi do uwolnienia łańcucha alkilowego jako trzeciorzędowego półproduktu - karbokationowego izopropylofenolu, który reaguje $\mathrm{z}$ wodą obecną w osadach ściekowych, czyli środowisku bytowania danych mikroorganizmów, tworząc nonanol-4-(2-hydroksypropan-2-yl)-fenol. To struktura podstawnika alkilowego mocno wpływa na zdolność do degradacji. Degradacja bisfenolu A i nonylofenolu jest inicjowana przez tę samą monooksygenazę, której aktywność zależy zarówno od NADPH, jak i dinukleotydu flawinoadeninowego. [Kolvenbach i in. 2007]. Monooksygenaza zależna od FAD, kodowana przez opdA, jest bezpośrednio odpowiedzialna za konwersję oktylofenolu (OP) do hydrochinonu i 2,4,4-trimetylo-1-pentenu [Porter i Hay 2007]. Na podstawie analizy sekwencji homologu opdA ze Sphingobium xenophagum Bayram została wykazana różnica czterech aminokwasów w sekwencjach białek u tego szczepu, w porównaniu ze szczepem TTNP3. Poziomy zaniku substratu i wyglądu hydrochinonu były znacznie niższe w hodowlach skupionych w obrębie odpA TTNP3 niż opdA Bayram. Oba szczepy wykorzystują proces substytucji ipso typu II dla degradacji alkilofenolu, a oprócz tego ich homologi opdA również kodują aktywność substytucyjną typu I ipso odpowiedzialną za degradację alkoksyfenoli [Porter i in. 2012]. Szczep Bayram wykazuje aktywność substytucji ipso w stosunku do 4-butoksyfenolu [Gabriel i in. 2007], a ekspresja opdA ma znaczący udział w tym procesie [Porter i in. 2012]. Doskonałe narzędzie do bioremediacji środowisk skażonych nonylofenolem stanowi konsorcjum NP-M2. Skład bakteryjny NP-M2 został określony za pomocą biblioteki 16S rDNA i późniejszym zsekwencjonowaniu, a w jego skład wchodzą przedstawiciele z rodzajów Sphingomonas, Pseudomonas, Alicycliphilus i Acidovorax. W tym przypadku szlak degradacji izomerów nonylofenolu jest zapoczątkowany utlenianiem pierścienia benzenowego, po którym następuje stopniowa biodegradacja półproduktów łańcuchu bocznym. Ścisła współpraca efektywnych mikroorganizmów w konsorcjum NP-M2 umożliwia szybką degradację izopentanolu, heksanolu i kwasu nonanowego, a także hydrochinonu w wyniku działania enzymów. Dochodzi nawet do częściowego zmniejszenia ilości nonanolu. Gen sMO obecny w bakteriach Alicycliphilus denitrificans, wchodzących w skład konsorcjum degradacyjnego uczestniczy w katalitycznej reakcji konwersji oktylo- 
fenolu do hydrochinonu oraz rozgałęzionych alkoholi będących metabolitami. W konsorcjum nie wykryto genów kodujących enzymy rozpadu alkanów i n-alkanów [Bai i in. 2017], ale geny takie (ALK i C23O) wykryte zostały w liniowym szczepie Sphingobium, który również degraduje 4-nonylofenole [Wang i in. 2014].

\section{Biodegradacja przez grzyby}

Procesy rozkładu alkilofenoli przez grzyby są znacznie słabiej poznane od analogicznych procesów u bakterii [Corvini i in. 2006]. Badane szczepy grzybów należą przede wszystkim do ligninolitycznych gatunków usuwających ze środowiska ksenobiotyki na drodze biodegradacji przez zewnątrzkomórkowe oksydoredyktazy: peroksydazy i lakazę lub przy udziale monooksygenazy cytochrom P450 [Junganns i in. 2005, Martin i in. 2009, Cajthaml 2015, Różalska i in. 2015, Mtibaà i in. 2019]. Wśród badanych grzybów występuje duże zróżnicowanie szlaków biodegradacji, nawet w obrębie jednego gatunku, co wykazali Nowak i in. [2019] na przykładzie rodzaju Metarhizobium. Przeprowadzone analizy wykazały, że u $M$. robertsii $i$ M. guizhouense charakterystyczna jest oksydacja terminalnej grupy metylowej łańcucha alifatycznego, z kolei u M. lepidiotae i. M. majus utleniane są grupy metylowe części środkowej łańcucha. Mechanizm usuwania nonylofenolu przez $M$. robertsii i $M$. guizhousense wydaje się być wydajniejszy. Podczas 48-godzinnej inkubacji z 4-n-nonylofenolem w stężeniu początkowym $50 \mathrm{mg} / \mathrm{l}$ wymienione gatunki zdegradowały $95 \%$ związku w porównaniu z $60 \%$ degradacji przez M. lepidiotae i M. majus.

Mechanizm transformacji alkilofenoli przez cytochrom P450 oparty jest na utlenianiu omega ( $\omega$-oksydacja), będącym alternatywnym szlakiem dla utleniania beta (obejmuje utlenianie węgla w pozycji $\omega$ ) [Syed i in. 2011, 2013]. W innych badaniach założono, ze produkty utleniania omega ulegają następnie beta-oksydacji, wskutek której następuje usunięcie końcowych atomów węgla [Różalska i in. 2010; Corvini i in. 2006]. Mtibaà i in.[2019] w swoich badaniach uzyskali wydajność biodegradacji nonylofenoli w 95\%, 4-tert-oktylofenolu w 100\% w trakcie 8-godzinnej inkubacji za pomocą Ascomycetes thielavia sp. HJ22 w stężeniu $22 \mathrm{mg} / \mathrm{l}$. Badany szczep wykorzystuje mechanizm oparty na połączeniu wydzielania lakazy z biosorpcją do biodegradacji.

\section{Podsumowanie}

Mikroorganizmy z powodzeniem mogą znaleźć zastosowanie w oczyszczaniu ścieków zanieczyszczonych alkilofenolami. W szczególności grzyby wykazują dużą wszechstronność $\mathrm{w}$ ich biodegradacji ze względu na zaangażowanie dwóch różnych systemów, tj. wewnątrzkomórkowego systemu cytochromu P450 oraz opartego na udziale zewnątrzkomórkowych oksydoreduktaz. Niemniej wymagane są dalsze badania mające na celu dokładniejsze zbadanie mechanizmów rozkładu oraz szlaków degradacji alkilofenoli. 


\section{Bibliografia}

Bai N., Abuduaini R., Wang S., Zhang M., Zhu X., Zhao Y., 2017. Nonylphenol biodegradation characterizations and bacterial composition analysis of an effective consortium NP-M2. Environ. Poll. 220, 95-104, https://doi.org/10.1016/j.envpol.2016.09.027

Cajthaml T., 2015. Biodegradation of endocrine-disrupting compounds by ligninolytic fungi: mechanisms involved in the degradation. Environ. Microbiol. 17(12), 4822-4834, https://doi.org/10.1111/1462-2920.12460

Chakraborty J., Dutta T.K., 2006. Isolation of a Pseudomonas sp. Capable of Utilizing 4-Nonylphenol in the Presence of Phenol, J. Microbiol. Biotechnol. 16(11) 1740-1746.

Corvini P.F.X., Schäffer A., Schlosser D., 2006. Microbial degradation of nonylphenol and other alkylphenols - our evolving view. Appl. Microbiol. Biotechnol. 72(2), 223-243, doi:10.1007/s00253-006-0476-5

Corvini P., Vinken R., Hommes G., Schmidt B., Dohmann M., 2004. Degradation of the Radioactive and Non-labelled Branched 4(3',5'-dimethyl 3'-heptyl)-phenol Nonylphenol Isomer by Sphingomonas TTNP3. Biodegradation 15(1), 9-18, https://doi.org/10.1023/B:BIOD.0000009937.20251.d2

Directive 2008/105/EC of the European Parliament and of the Council of 16 December 2008. Off. J. Europ. Union L 348/84, 24.12.2008

Gabriel F.L.P., Cyris M., Jonkers N., Giger W., Guenther K., Kohler H.P.E., 2007. Elucidation of the ipso-substitution mechanism for sidechain cleavage of $\alpha$-quaternary 4-nonylphenols and 4-tbutoxyphenol in Sphingobium xenophagum Bayram. Appl. Environ. Microbiol. 73(10) 3320-3326, doi:10.1128/AEM.02994-06

Hao R., Zhang Y., Lv J., Zheng X.Y., 2010. Study on primary metabolites and possible biodegradation pathways of nonylphenol. Intern. J. Environ. Poll. 42(1-3), 136-147, https://doi.org/10.1504/IJEP.2010.034231

Junghanns C., Moeder M., Krauss G., Martin C., Schlosser D., 2005. Degradation of the xenoestrogen nonylphenol by aquatic fungi and their laccases. Microbiology 151(1), 45-57, doi:10.1099/mic.0.27431-0

Kamińska G., Kudlek E., Dudziak M., Bohdziewicz J., 2016. Skuteczność usuwania wybranych substancji aktywnych biologicznie podczas mechaniczno-biologicznego oczyszczania ścieków. Inż. Ekol. 50, 201-209, doi:10.12912/23920629/65502

Kolvenbach B., Schlaich N., Raoui Z., Prell J., Zühlke S., Schäffer A., Guengerich F.P., Corvini P.F.X., 2007. Degradation Pathway of Bisphenol A: Does ipso Substitution Apply to Phenols Containing a Quaternary $\alpha$-Carbon Structure in the para Position? Appl. Environ. Microbiol. 73(15), 4776-4784, https://doi.org/10.1128/AEM.00329-07

Kolvenbach B.A., Corvini P.X., 2012. The degradation of alkylphenols by Sphingomonas sp. strain TTNP3 - a review on seven years of research, New Biotechnol. 30(1), 88-95, https://doi.org/10.1016/j.nbt.2012.07.008

Martin C., Corvini P.F., Vinken R., Junghanns C., Krauss G., Schlosser D., 2009. Quantification of the influence of extracellular laccase and intracellular reactions on the isomer-specific biotransformation of the xenoestrogen technical nonylphenol by the aquatic hyphomycete Clavariopsis aquatica. Appl. Environ. Microbiol. 75(13), 4398-4409, doi:10.1128/AEM.00139-09

Mtibaà R., Ezzanad A., Aranda E., Pozo C., Ghariani B., Moraga J., Nasri M., Cantoral J.M., Garrido C., Mechichi T., 2019. Biodegradation and toxicity reduction of nonylphenol, 4-tertoctylphenol and 2, 4-dichlorophenol by the ascomycetous fungus Thielavia sp HJ22: Identification of fungal metabolites and proposal of a putative pathway. Sci. Total Environ. 708, 135129, https://doi.org/10.1016/j.scitotenv. 2019.135129

Naylor C.G., Mieure J.P., Adams W.J., Weeks J.A., Castaldi F.J., Ogle L.D., Romano R.R., 1992. Alkylphenol ethoxylates in the environment. J. Am. Oil Chem. Soc. 69(7), 695-703, https://doi.org/10.1007/BF02635812

Nimrod A.C., Benson W.H., 1996. Environmental estrogenic effects of alkylphenol ethoxylates. Crit. Rev. Toxicol. 26(3), 335-364, https://doi.org/10.3109/10408449609012527 
Nowak M., Soboń A., Litwin A., Różalska S., 2019. 4-n-nonylphenol degradation by the genus Metarhizium with cytochrome P450 involvement. Chemosphere 220, 324-334, https://doi.org/10.1016/j.chemosphere.2018.12.114

Porter A.W., Campbell B.R., Kolvenbach B.A. Corvini P.X., Benndorf D., Rivera-Cancel G., Hay A.G., 2012. Identification of the flavin monooxygenase responsible for ipso substitution of alkyl and alkoxyphenols in Sphingomonas sp. TTNP3 and Sphingobium xenophagum Bayram. Appl. Microbiol. Biotechnol. 94(1), 261-272, https://doi.org/10.1007/s00253-011-3621-8

Porter A.W., Hay A.G., 2007. Identification of opdA, a gene involved in the biodegradation of the endocrine disrupter octylphenol. Appl. Environ. Microbiol. 73(22) 7373-7379, https://doi.org/10.1128/AEM.01478-07

Różalska S., Szewczyk R., Długoński J., 2010. Biodegradation of 4-n-nonylphenol by the nonligninolytic filamentous fungus Gliocephalotrichum simplex: a proposal of a metabolic pathway. J. Hazardous Materials 180(1-3), 323-331, doi:10.1016/j.jhazmat.2010.04.034

Syed K., Porollo A., Lam Y.W., Grimmett P.E., Yadav J.S., 2013. CYP63A2, a catalytically versatile fungal P450 monooxygenase capable of oxidizing higher-molecular-weight polycyclic aromatic hydrocarbons, alkylphenols, and alkanes. Appl. Environ. Microbiol. 79(8), 2692-2702, doi:10.1128/aem.03767-12

Syed K., Porollo A., Lam Y.W., Yadav J.S., 2011. A fungal P450 (CYP5136A3) capable of oxidizing polycyclic aromatic hydrocarbons and endocrine disrupting alkylphenols: role of Trp 129 and Leu 324. PLoS ONE 6(12), e28286, doi:10.1371/journal.pone.0028286

Szymański A., Wyrwas B., 2010. Alkilofenole i ich oksyetylaty - substancje niebezpieczne o działaniu endokrynnym. W: Zaopatrzenie w wodę, jakość i ochrona wód. Wyd. PZITS, Poznań.

Tuan N.N., Hsieh H.-C., Lin Y.W., Huang S.L., 2011. Analysis of bacterial degradation pathways for long-chain alkylphenols involving phenol hydroxylase, alkylphenol monooxygenase and catechol dioxygenase genes. Bioresource Technol. 102(5), 4232-4240, https://doi.org/10.1016/j.envpol.2016.09.027

Wang Z., Yang Y., Sun W., Xie S., 2014. Biodegradation of nonylphenol by two alphaproteobacterial strains in liquid culture and sediment microcosm. Intern. Biodeterior. Biodegrad. 92, 1-5, doi.org/10.1016/j.ibiod.2014.04.004

Wojcieszyńska D., Guzik U., Hupert-Kocurek K., Marszałek J., 2011. Biochemiczne i fizjologiczne skutki oddziaływania związków fenolowych na organizm człowieka. Med. Środ.14(1), 105-111

Xie Y., Pan Y., Bai B., Xu Z., Ding L., Li Q., Xu Y., Zhu T., 2015. Degradation performance and optimal parameters of two bacteria in degrading nonylphenol. J. Computational Theoret. Nanosci. 12(9), 2657-2663, https://doi.org/10.1166/jetn.2015.4159

Ying G.G., Williams B., Kookana R., 2002. Environmental Fate of alkylphenols and alkylphenol ethoxylates - a review. Environ. Internat. 28(3), 215-226, doi:10.1016/s0160-4120(02)00017-x 
Aleksander Chudy ${ }^{1}$

\section{Rola elektromobilności w ograniczaniu emisji zanieczyszczeń powietrza i gazów cieplarnianych}

The role of electromobility in the mitigation of air pollution and greenhouse gas emissions

Globalna redukcja emisji zanieczyszczeń powietrza i gazów cieplarnianych, szczególnie w sektorze transportowym jest bardzo istotnym zagadnieniem. Konsekwencje zmian klimatycznych spowodowanych działalnością człowieka są poważne. Światowi politycy zajmują się tym, jak można ograniczyć przyczyny globalnego ocieplenia zarówno na poziomie krajowym, jak i globalnym. Redukcja emisji gazów cieplarnianych jest sposobem na zminimalizowanie konsekwencji zmian klimatu, które wpływają na środowisko $\mathrm{w}$ wielu aspektach. W związku z rosnącym zagrożeniem dla klimatu, zmniejszenie emisji gazów cieplarnianych oraz zanieczyszczeń powietrza stało się istotnym czynnikiem politycznym w wielu społecznościach. Wpływ przemysłu transportowego na atmosferę jest uważany za ważny punkt zwrotny w rozwiązywaniu problemów związanych ze zmianami środowiskowymi. W minimalizowaniu ogólnych emisji gazów cieplarnianych kontrola emisji z transportu musi odgrywać znaczącą rolę. Jednym ze sposobów na zmniejszenie zanieczyszczeń pochodzących z sektora transportowego jest zwiększenie udziału elektromobilności [Hoolohan i in. 2013, Ellabban i in. 2014, Urry 2015, Un-Noor i in. 2017, Baskar i Dhulipala 2018, Cavanagh 2021, Zhao i in. 2021].

Coraz częściej elektromobilność pojawia się w polityce transportowej Unii Europejskiej oraz w poszczególnych państwach członkowskich. Uznawana jest za jedno $\mathrm{z}$ najważniejszych narzędzi $\mathrm{w}$ działaniach zmierzających do ograniczenia negatywnego wpływu transportu na środowisko [Auvinen i in. 2016]. Elektromobilność staje się znaczącą alternatywą dla tradycyjnych systemów mobilności, zyskując z roku na rok na znaczeniu w całej UE, a pojazdy elektryczne wydają się być jednymi z najbardziej obiecujących pojazdów napędzanych paliwami alternatywnymi. Elektromobilność i pojazdy elektryczne mogą stać się kluczowym czynnikiem zrównoważonej i przyjaznej dla środowiska mobilności w przyszłości, przyczyniając się do zmniejszenia zanieczyszczenia powietrza i emisji gazów cieplarnianych. Brak lokalnych emisji zanieczyszczeń powietrza przez pojazdy elektryczne jest szczególnie ważny na obszarach miejskich, ponieważ charakteryzują się one dużą gęstością zaludnienia i dużym ruchem ulicznym. Zakłada się zatem, że elektromobilność może stać się dominującą technologią stosowaną w przyszłej mobilności w aglomeracjach miejskich. Zastosowanie energii elektrycznej jako alternatywnego źródła zasilania pojazdów pozwala na rozwój koncepcji zrównoważonej mobilności. Koncepcja ta ma na celu zmniejszenie liczby pojazdów z silnikami spali-

\footnotetext{
${ }^{1}$ Politechnika Lubelska, Wydział Elektrotechniki i Informatyki, Katedra Elektrotechniki i Elektrotechnologii, a.chudy@pollub.pl
} 
nowymi, szczególnie na obszarach miejskich, a tym samym zmniejszenie ich negatywnego wpływu na środowisko i zdrowie ludzi. Jednak realizacja założeń e-mobilności wiąże się obecnie z szeregiem przeszkód i ograniczeń. Obejmują one ograniczoną gamę pojazdów dostępnych na rynku i ich wysoką cenę zakupu, słabe przygotowanie sieci elektroenergetycznej, ograniczoną sieć stacji ładowania pojazdów, czy też ograniczony zasięg pojazdów elektrycznych [Pietrzak i Pietrzak 2020].

W rozdziale przedstawiono informacje na temat źródeł zanieczyszczeń powietrza, wpływu zanieczyszczeń powietrza na ludzkie zdrowie oraz roli samochodów elektrycznych w kontroli emisji zanieczyszczeń powietrza oraz dwutlenku węgla.

\section{Pochodzenie zanieczyszczeń powietrza}

Szkodliwe lub nadmierne ilości substancji w tym gazów, cząsteczek i biomolekuł wprowadzane do atmosfery ziemskiej, które powodują szkodliwe skutki dla człowieka i ekosystemu określa się mianem zanieczyszczenia powietrza. Substancją mogą być cząstki stałe, krople cieczy lub gazy. Zanieczyszczenia mogą być pochodzenia naturalnego lub wytworzone przez człowieka, ale można podzielić je także na pierwotne i wtórne. Popiół $\mathrm{z}$ erupcji wulkanu to zanieczyszczenie pierwotne. Inne przykłady to tlenek węgla czy dwutlenek węgla pochodzące ze spalin pojazdów mechanicznych lub dwutlenek siarki uwalniany z fabryk. $\mathrm{CO}_{\mathrm{x}}, \mathrm{SO}_{\mathrm{x}}, \mathrm{NO}_{\mathrm{x}}, \mathrm{CH}_{\mathrm{x}}$, pył zawieszony $(\mathrm{PM})$, wolne rodniki, metale toksyczne, chlorofluorowęglowodory, amoniak, zanieczyszczenia radioaktywne to niektóre z zanieczyszczeń pierwotnych. Zanieczyszczenia wtórne nie są emitowane bezpośrednio, lecz powstają $\mathrm{w}$ powietrzu w wyniku reakcji zanieczyszczeń pierwotnych. Zanieczyszczenia wtórne obejmują pozostałości po zanieczyszczeniach pierwotnych, które reagują z atmosferą i światłem słonecznym, tworząc smog chemiczny. Źródła tych zanieczyszczeń są w postaci [Jenn i in. 2020, Varma i in. 2020]:

- dymu z elektrowni na paliwa kopalne,

- pożarów lasów kontrolowanych i niekontrolowanych,

- odpadów składowanych na wysypiskach i ich spalania,

- nawozów sztucznych i fabryk,

- pyłów ze źródeł naturalnych i budowlanych,

- gazów cieplarnianych z upraw,

- samochodów.

Transport drogowy jest znaczącym źródłem zanieczyszczeń powietrza i gazów cieplarnianych. W skali globalnej emisje $\mathrm{z}$ ruchu drogowego stanowią 3\% tlenków azotu $\left(\mathrm{NO}_{\mathrm{x}}=\mathrm{NO}+\mathrm{NO}_{2}\right), 9 \% \mathrm{PM}, 54 \% \mathrm{CO}, 34 \% \mathrm{CO}_{2}$ [Varma i in. 2020]. Sektor transportowy generuje zanieczyszczenia powietrza w czterech etapach: podczas produkcji pojazdu, spalania paliwa, wydobycia paliwa, pracy pojazdu.

\section{Wpływ zanieczyszczenia powietrza na zdrowie czlowieka}

Pod względem zagrożeń dla zdrowia każdy nietypowy materiał zawieszony w powietrzu, który powoduje trudności w normalnym funkcjonowaniu narządów ludzkich, jest określany jako toksyczny. Według dostępnych danych, narażenie na zanieczyszczenia powietrza skutkuje problemami z układami oddechowym, sercowo-naczyniowym czy wzrokowym. Zanieczyszczenie powietrza może wpłynąć również na układy immunologicz- 
ny i rozrodczy oraz przyczynić się do powikłań neuropsychiatrycznych. W perspektywie długoterminowej mogą pojawić się także nowotwory. Wykazano, że nawet niewielka ilość substancji toksycznych w powietrzu jest niebezpieczna dla grup wrażliwych, w tym dzieci, osób starszych i pacjentów cierpiących na choroby układu oddechowego i sercowo-naczyniowego [Makri i Stilianakis 2008, Ghorani-Azam i in. 2016].

Większość zanieczyszczeń przedostaje się do organizmu drogami oddechowymi, więc układ oddechowy znajduje się na pierwszej linii walki w powstawaniu i postępie chorób spowodowanych zanieczyszczeniami powietrza. W zależności od dawki wdychanych zanieczyszczeń i odkładania się w komórkach docelowych powodują różny poziom uszkodzeń układu oddechowego. Pierwszym efektem jest podrażnienie, zwłaszcza tchawicy, które wywołuje zaburzenia głosu. Zanieczyszczenie powietrza jest również uważane za główny czynnik ryzyka środowiskowego dla niektórych chorób układu oddechowego, takich jak astma i rak płuc. Zanieczyszczenia powietrza, zwłaszcza PM $\mathrm{i}$ inne wdychane chemikalia, takie jak kurz, $\mathrm{O}_{3}$ i benzen, powodują poważne uszkodzenie układu oddechowego. Astma jest chorobą układu oddechowego, która może rozwinąć się w wyniku narażenia na substancje toksyczne w powietrzu. Niektóre badania potwierdziły związek między zanieczyszczeniem powietrza spowodowanym ruchem drogowym a występowaniem przewlekłej obturacyjnej choroby płuc [Zhang i Batterman 2013, Manisalidis i in. 2020].

Wiele badań eksperymentalnych wykazało bezpośredni związek między narażeniem na zanieczyszczenie powietrza a chorobami serca. Zanieczyszczenie powietrza jest również związane ze zmianami liczby białych krwinek, które mogą również wpływać na układ sercowo-naczyniowy. Badanie na modelach zwierzęcych zasugerowało ścisły związek między nadciśnieniem a narażeniem na zanieczyszczenie powietrza. Zanieczyszczenie powietrza z powodu ruchu drogowego, a szczególnie narażenie na wysokie poziomy $\mathrm{NO}_{2}$, wiąże się z przerostem prawej i lewej komory serca [Leary i in. 2014, Snow i in. 2014, Steenhof $i$ in. 2014].

\section{Kontrola emisji dwutlenku węgla i zanieczyszczeń powietrza a elektromobilność}

Tradycyjne samochody z silnikami spalinowymi generują między innymi dwutlenek węgla $\mathrm{CO}_{2}$, sześciofluorek siarki $\mathrm{SF}_{6}$, tlenek węgla $\mathrm{CO}$, węglowodory i tlenki diazotu $\mathrm{N}_{2} \mathrm{O}$ oraz sadzę i cząstki stałe. Główną zaletą pojazdów elektrycznych jest to, że nie emitują one żadnych zanieczyszczeń z rury wydechowej [Ghosh 2020]. W Unii Europejskiej samochody elektryczne mogą ograniczyć emisję gazów cieplarnianych średnio o $50-60 \% \mathrm{w}$ porównaniu z pojazdami z silnikami spalinowymi [Moro i Lonza 2018]. Ogólnie rzecz biorąc, potencjał ograniczenia emisji gazów cieplarnianych przez pojazdy elektryczne może wahać się od $10 \%$ do $60 \% \mathrm{w}$ zależności od rodzaju pojazdu i położenia geograficznego [Gómez Vilchez i Jochem 2020]. Chociaż pojazdy elektryczne zmniejszają emisję gazów cieplarnianych, to jednocześnie zwiększają zapotrzebowanie na energię elektryczną. Generuje to zwiększoną emisję gazów cieplarnianych, ponieważ do wytworzenia energii elektrycznej nadal wykorzystuje się głównie paliwa kopalne [Ghosh 2020].

Pomiary emisji gazów cieplarnianych w elektromobilności dotyczą jedynie bezpośredniej oszczędności emisji wynikającej z bezpośredniego spalania paliw kopalnych i nie uwzględniają emisji pośredniej, która jest związana z przesyłaniem i wytwarzaniem energii elektrycznej [Gupta $\mathrm{i}$ in. 2020, Kim i in. 2020]. Dlatego też zaleca się 
wytwarzanie energii elektrycznej z alternatywnych źródeł, takich jak energia słoneczna, wiatrowa, biomasa i energia jądrowa [Winyuchakrit i in. 2017]. Należy zauważyć, że porównanie emisji gazów cieplarnianych z pojazdów elektrycznych i z silników spalinowych zależy w pełni od założeń przyjętych w procesie obliczeń. Można zauważyć, że redukcja emisji gazów cieplarnianych przez pojazdy elektryczne zależy od źródeł energii elektrycznej wykorzystywanych do ich ładowania. Dekarbonizacja sektora transportu z wykorzystaniem pojazdów elektrycznych nie zawsze jest możliwa, gdyż nie są one odpowiednim rozwiązaniem technologicznym dla wszystkich krajów [Abdul-Manan 2015].

Międzynarodowa Agencja Energetyczna przewiduje, że w 2040 r. możliwe będzie zwiększenie emisji $\mathrm{CO}_{2} \mathrm{w}$ sektorze energetycznym o $16 \% \mathrm{w}$ porównaniu z poziomem z 2014 r. Wynika to przede wszystkim z przewidywanego 87\% wzrostu globalnego zapotrzebowania na energię elektryczną. Jeżeli energia elektryczna będzie pochodziła z odnawialnych źródeł energii, to emisja gazów cieplarnianych przez pojazdy elektryczne będzie niższa. Jednakże w przypadku pojazdów elektrycznych ocena końca żywotności baterii również jest niezbędna. Recykling akumulatorów jest ważny, ponieważ pozwala odzyskać lit i kobalt, które są cennymi metalami, oraz ograniczyć ołów, kadm i miedź, które są substancjami niebezpiecznymi [Hannan i in. 2017, Chudy 2020, Ghosh 2020].

Tradycyjne samochody z silnikami spalinowymi generują nie tylko gazy cieplarniane, ale również cząstki stałe. Ze względu na brak emisji zanieczyszczeń z rury wydechowej, samochody elektryczne wytwarzają cząstki stałe tylko z resuspensji pyłu drogowego, zużycia drogi, czy hamulców i opon. Około 50-85\% cząstek $\mathrm{PM}_{10}$ i $\mathrm{PM}_{2,5}$ generowanych przez ruch drogowy pochodzi z emisji niespalinowej. Masa pojazdów elektrycznych jest wyższa niż pojazdów spalinowych ze względu na akumulator, co w konsekwencji wpływa na zużycie opon. Dlatego też uważa się, że znaczące zmniejszenie emisji PM z pojazdów elektrycznych jest możliwe jedynie poprzez dalsze zmniejszanie masy akumulatorów [Nichols i in. 2015, Ghosh 2020].

Wang i in. [2016] opracowali model pojazdu hybrydowego, który może zmniejszyć zużycie paliwa i zanieczyszczenie. Graham-Rowe i in. [2012] przeanalizowali ankietę na temat pojazdów elektrycznych typu plug-in, które mogą emitować znacznie mniej dwutlenku węgla, w przeciwieństwie do pojazdów spalinowych, a tym samym znacznie obniżyć koszty transportu bez ograniczania użytkowania samochodów. Analizując przyszłe wykorzystanie nowych typów samochodów, należy mieć świadomość potencjalnych reakcji konsumentów. Wyniki badań ujawniają możliwe przeszkody w korzystaniu z samochodów elektrycznych typu plug-in przez tradycyjnych konsumentów obecnej generacji, na przykład przedkładanie osobistych wymagań transportowych nad konsekwencje środowiskowe. Słabo rozwinięta sieć stacji ładowania również jest jedną z głównych barier utrudniających bardziej dynamiczny rozwój elektromobilności w wielu krajach Unii Europejskiej.

\section{Podsumowanie}

Ograniczenie emisji gazów cieplarnianych w stopniu wystarczającym do ustabilizowania ich $\mathrm{w}$ atmosferze jest bardzo ważnym wyzwaniem globalnym. Zmiany klimatyczne spowodowane zanieczyszczeniem powietrza są w dzisiejszych czasach tematem debaty na forach międzynarodowych. Rządy na całym świecie zajęły się problemem zanieczyszczenia powietrza poprzez duże inwestycje ukierunkowane na poprawę jego 
jakości. Cel, jakim jest czystsze powietrze, wymaga inwestycji w technologie energii odnawialnej zarówno ze strony rządu, jak i przemysłu. Redukcja emisji zanieczyszczeń powietrza może nastąpić poprzez wykorzystanie samochodów elektrycznych wspomaganych sztuczną inteligencją. Należałoby również wdrożyć więcej zrównoważonych źródłem energii w postaci ogniw słonecznych, turbin wiatrowych i złożonych form bioenergii. Wykorzystanie pojazdów elektrycznych wspomaganych sztuczną inteligencją może zmniejszyć zanieczyszczenie powietrza.

Kontrolowanie zanieczyszczeń powodowanych przez samochody może być ważnym krokiem w procesie zwalczania lub kontroli zanieczyszczeń. Obecna technologia akumulatorów jest lepsza niż poprzednie, ale niska gęstość energii nie sprawia, że obecne pojazdy elektryczne są zerowoemisyjne, ponieważ ostatecznie zużywają one energię elektryczną wykorzystywaną przez spalanie paliw kopalnych. Oprócz tego nadmierna zależność od nieodnawialnych źródeł energii, niska sprawność paneli słonecznych, wiatraków, niewystarczająca ekspozycja na inne odnawialne źródła energii również nie czynią sektora energetycznego czystszym.

Mimo wszystko pojazdy elektryczne na ten moment nie są tak niskoemisyjne, jak się przypuszcza, ale nie ma wątpliwości co do tego, że w przyszłości będą dominowały w sektorze transportu. Wraz z wykorzystaniem nowych typów akumulatorów (na przykład akumulatorów litowo-powietrznych, które mogą magazynować dziesięciokrotnie więcej energii niż akumulatory litowo-żelazowo-fosforanowe) oraz migracji w kierunku efektywniejszego wykorzystania energii jądrowej, wiatru, czy słońca zmniejszy się poziom zanieczyszczenia powietrza.

\section{Bibliografia}

Abdul-Manan A.F.N., 2015. Uncertainty and differences in GHG emissions between electric and conventional gasoline vehicles with implications for transport policy making. Energy Policy 87, 1-7. doi:10.1016/j.enpol.2015.08.029.

Auvinen H., Järvi T., Kloetzke M., Kugler U., Bühne J.-A., Heinl F., Kurte J., Esser K., 2016. Electromobility Scenarios: Research Findings to Inform Policy. Transportat. Res. Proc. 14, 2564-2573. doi:10.1016/j.trpro.2016.05.346.

Baskar S., Dhulipala V.S., 2018. Secure and compact implementation of optimized Montgomery multiplier based elliptic curve cryptography on FPGA with road vehicular traffic collecting protocol for VANET application. Intern. J. Heavy Vehicle Syst. 25 (3/4), 485-497. doi:10.1504/IJHVS.2018.094835.

Cavanagh R., 2021. Energy efficiency and decarbonization: Priorities for regulated utilities. Electricity J. 34 (2), 106908. doi:10.1016/j.tej.2020.106908.

Chudy A., 2020. Akumulatory litowo-jonowe w samochodach elektrycznych - regeneracja, zastosowanie wtórne i recykling, w: Problemy i wyzwania współczesnego rolnictwa oraz ochrony środowiska. Środowisko - Roślina - Zwierzę - Produkt. T. 1. Wyd. UP w Lublinie, Lublin, 26-34.

Ellabban O., Abu-Rub H., Blaabjerg F., 2014. Renewable energy resources: Current status, future prospects and their enabling technology. Renew. Sust. Energ. Rev. 39, 748-764. doi:10.1016/j.rser.2014.07.113.

Ghorani-Azam A., Riahi-Zanjani B., Balali-Mood M., 2016. Effects of air pollution on human health and practical measures for prevention in Iran. J. Res. Med. Sci. Official J. Isfahan Univ. Med. Sci. 21, 65. doi:10.4103/1735-1995.189646. 
Ghosh A., 2020. Possibilities and Challenges for the Inclusion of the Electric Vehicle (EV) to Reduce the Carbon Footprint in the Transport Sector, Rev. Energ. 13 (10), 2602. doi:10.3390/en13102602.

Gómez Vilchez J.J., Jochem P., 2020. Powertrain technologies and their impact on greenhouse gas emissions in key car markets. Transportat. Res. Part D, Transport Environ. 80, 102214. doi:10.1016/j.trd.2019.102214.

Graham-Rowe E., Gardner B., Abraham C., Skippon S., Dittmar H., Hutchins R., Stannard J., 2012. Mainstream consumers driving plug-in battery-electric and plug-in hybrid electric cars: A qualitative analysis of responses and evaluations. Transportat. Res. Part A: Policy Pract. 46 (1), 140-153. doi:10.1016/j.tra.2011.09.008.

Gupta P., Tong D., Wang J., Zhuge W., Yan C., Wu Y., Luo S., He X., Ma F., 2020. Well-towheels total energy and GHG emissions of HCNG heavy-duty vehicles in China: Case of EEV qualified EURO 5 emissions scenario. Intern. J. Hydrog. Energy 45 (15), 8002-8014. doi:10.1016/j.ijhydene.2020.01.025.

Hannan M.A., Hoque M.M., Mohamed A., Ayob A., 2017. Review of energy storage systems for electric vehicle applications: Issues and challenges. Renewable and Sustainable Energy Rev. 69, 771-789. doi:10.1016/j.rser.2016.11.171.

Hoolohan C., Berners-Lee M., McKinstry-West J., Hewitt C.N., 2013. Mitigating the greenhouse gas emissions embodied in food through realistic consumer choices. Energy Policy 63, 1065-1074. doi:10.1016/j.enpol.2013.09.046.

Jenn A., Clark-Sutton K., Gallaher M., Petrusa J., 2020. Environmental impacts of extreme fast charging. Environ. Res. Lett. 15 (9), 94060. doi:10.1088/1748-9326/ab9870.

Kim I., Kim J., Lee J., 2020. Dynamic analysis of well-to-wheel electric and hydrogen vehicles greenhouse gas emissions: Focusing on consumer preferences and power mix changes in South Korea. Appl. Energy 260, 114281. doi:10.1016/j.apenergy.2019.114281.

Leary P.J., Kaufman J.D., Barr R.G., Bluemke D.A., Curl C.L., Hough C.L., Lima J.A., Szpiro A.A., van Hee V.C., Kawut S.M., 2014. Traffic-related air pollution and the right ventricle. The multi-ethnic study of atherosclerosis. Am. J. Respirat. Critical Care Med. 189 (9), 1093-1100. doi: $10.1164 / \mathrm{rccm} .201312-22980 \mathrm{OC}$.

Makri A., Stilianakis N.I., 2008. Vulnerability to air pollution health effects. Intern. J. Hygiene Environ. Health 211 (3-4), 326-336. doi:10.1016/j.ijheh.2007.06.005.

Manisalidis I., Stavropoulou E., Stavropoulos A., Bezirtzoglou E., 2020. Environmental and Health Impacts of Air Pollution: A Review. Front. Public Health 8, 14. doi:10.3389/fpubh.2020.00014.

Moro A., Lonza L., 2018. Electricity carbon intensity in European Member States: Impacts on GHG emissions of electric vehicles. Transportat. Res. Part D, Transport Environ. 64, 5-14. doi:10.1016/j.trd.2017.07.012.

Nichols B.G., Kockelman K.M., Reiter M., 2015. Air quality impacts of electric vehicle adoption in Texas. Transportat. Res. Part D, Transport Environ. 34 (8), 208-218. doi:10.1016/j.trd.2014.10.016.

Pietrzak K., Pietrzak O., 2020. Environmental Effects of Electromobility in a Sustainable Urban Public Transport. Sustainability 12 (3), 1052. doi:10.3390/su12031052.

Snow S.J., Cheng W., Wolberg A.S., Carraway M.S., 2014. Air pollution upregulates endothelial cell procoagulant activity via ultrafine particle-induced oxidant signaling and tissue factor expression. Toxicol. Sci.: Official J. Soc. Toxicol. 140 (1), 83-93. doi:10.1093/toxsci/kfu071.

Steenhof M., Janssen N.A.H., Strak M., Hoek G., Gosens I., Mudway I.S., Kelly F.J., Harrison R.M., Pieters R.H.H., Cassee F.R., Brunekreef B., 2014. Air pollution exposure affects circulating white blood cell counts in healthy subjects: the role of particle composition, oxidative potential and gaseous pollutants - the RAPTES project. Inhalat. Toxicol. 26 (3), 141-165. doi:10.3109/08958378.2013.861884.

Un-Noor F., Padmanaban S., Mihet-Popa L., Mollah M., Hossain E., 2017. A Comprehensive Study of Key Electric Vehicle (EV) Components, Technologies, Challenges, Impacts, and Future Direction of Development. Energies 10 (8), 1217. doi:10.3390/en10081217.

Urry J., 2015. Climate Change and Society, w: Michie J., Cooper C.L. (Eds.), Why the Social Sciences Matter. Palgrave Macmillan UK, London, 45-59. 
Varma M., Mal H., Pahurkar R., Swain R.; 2020. Comparative analysis of green house gases emission in conventional vehicles and electric vehicles. Intern. J. Adv. Sci. Technol. 29, 689-695.

Wang S., Fan J., Zhao D., Yang S., Fu Y., 2016. Predicting consumers' intention to adopt hybrid electric vehicles: using an extended version of the theory of planned behavior model. Transportation 43 (1), 123-143. doi:10.1007/s11116-014-9567-9.

Winyuchakrit P., Sukamongkol Y., Limmeechokchai B., 2017. Do Electric Vehicles Really Reduce GHG Emissions in Thailand? Energy Proced. 138, 348-353. doi:10.1016/j.egypro.2017.10.137.

Zhang K., Batterman S., 2013. Air pollution and health risks due to vehicle traffic. Sci. Total Environ. 450-451, 307-316. doi:10.1016/j.scitotenv.2013.01.074.

Zhao J., Xi X., Na Q., Wang S., Kadry S.N., Kumar P.M., 2021. The technological innovation of hybrid and plug-in electric vehicles for environment carbon pollution control. Environ. Impact Assessment Rev. 86, 106506. doi:10.1016/j.eiar.2020.106506. 


\section{Aleksandra Garbacz ${ }^{1}$}

\section{Zjawisko quorum sensing u bakterii}

Quorum sensing phenomenon in bacteria

Quorum sensing (QS - ang.) to system porozumiewania się komórek bakteryjnych za pośrednictwem chemicznych sygnałów dyfuzyjnych. QS uczestniczy w regulacji ekspresji genów w odpowiedzi na gęstość komórek w populacji drobnoustrojów. Opiera się na wytwarzaniu i rozpoznaniu cząsteczek sygnalizacyjnych zwanych autoinduktorami (AI - ang. autoinducers), a następnie nagromadzeniu ich w środowisku oraz rozpoznaniu przez receptory, co skutkuje wywołaniem odpowiedzi bakteryjnej [Jaworski $\mathrm{i}$ in. 2005, Rutherford i Bassler 2012]. Quorum sensing pełni ważną funkcję w regulacji procesów komórkowych. takich jak bioluminescencja, sporulacja, wirulencja, biosynteza metabolitów wtórnych, produkcja biofilmu, replikacja DNA, przekazywanie plazmidów i oporność bakterii na różne rodzaje antybiotyków [Baranowska i Rodziewicz 2008, Li i Nair 2012]. Zjawisko QS występuje zarówno u bakterii Gram-ujemnych, jak i Gramdodatnich. Obie z tych grup wykształciły różne systemy autoinduktorów oraz odmienne systemy regulacji ekspresji genów w odpowiedzi na cząsteczki sygnalizacyjne.

\section{Zasady systemu quorum sensing}

Funkcjonowanie systemu quorum sensing oparte jest na trzech następujących zasadach:

- im większa gęstość komórek bakteryjnych w hodowli, tym większa produkcja i identyfikacja autoinduktorów (AI), a także silniejsza odpowiedź;

- wykrywanie cząsteczek sygnalizacyjnych odbywa się przez białka receptorowe znajdujące się w cytoplazmie lub błonie komórek;

- system ten bazuje na sprzężeniu zwrotnym polegającym na tym, że zidentyfikowanie autoinduktorów przez bakterie determinuje wytwarzanie kolejnych cząsteczek sygnałowych [Rutherford i Bassler 2012].

Tak wyspecjalizowany system umożliwia mikroorganizmom kontrolowanie liczby komórek populacji oraz ich aktywności fizjologicznej [Jaworski i in. 2005].

\section{Autoinduktory}

Autoinduktory są drobnocząsteczkowymi związkami charakteryzującymi się odmienną strukturą dla poszczególnych grup mikroorganizmów (tab. 1). Pełnią one ważną funkcję w identyfikacji zagęszczenia bakterii [Vadakkan i in. 2018]. Ich stężenie wzra-

\footnotetext{
${ }^{1}$ Uniwersytet Przyrodniczy w Lublinie, Wydział Nauk o Żywności i Biotechnologii, Studenckie Koło Naukowe Biotechnologów „Biom”, aleksandragarbacz@o2.pl
} 
sta w środowisku wraz z zwiększającą się gęstością komórek bakteryjnych oraz uzależnione jest od otoczenia. Bakterie potrafią reagować na zmiany stężenia i rodzaj tych związków chemicznych. W trakcie osiągnięcia granicznego stężenia przez autoinduktory, dochodzi do wzbudzenia ekspresji genów, co skutkuje powstaniem efektu metabolicznego u bakterii, które potrafią przejąć sygnał [Czajkowski i Jafra 2004, Baranowska i Rodziewicz 2008].

Tabela 1. Rodzaje autoinduktorów w quorum sensing

\begin{tabular}{|c|c|c|}
\hline $\begin{array}{c}\text { Częstość } \\
\text { występowania }\end{array}$ & Rodzaje autoinduktorów & Źródło \\
\hline \multirow{4}{*}{ Duża } & $\begin{array}{l}\text { Peptydy autoindukcyjne (AIP - ang. Auto- } \\
\text { inducing Peptides) u bakterii Gram- } \\
\text {-dodatnich }\end{array}$ & $\begin{array}{l}\text { [Li i Nair 2012, Vadakkan } \\
\text { i in. 2018] }\end{array}$ \\
\hline & $\begin{array}{l}\text { Autoinduktory zawierające lakton acylo- } \\
\text { homoseryny (AHL - ang. Acyl Homoserine } \\
\text { Lactone) u bakterii Gram-ujemnych }\end{array}$ & \multirow[t]{2}{*}{$\begin{array}{l}\text { [Li i Nair 2012, Whiteley } \\
\text { i in. 2017, Vadakkan i in. } \\
\text { 2018] }\end{array}$} \\
\hline & $\begin{array}{l}\text { Autoinduktor-2 (AI-2 - ang. Autoinducer-2) } \\
\text { u bakterii mieszanych }\end{array}$ & \\
\hline & $\begin{array}{l}\text { Autoinduktor-3 (AI-3 - ang. Autoinducer-3) } \\
\text { u bakterii mieszanych }\end{array}$ & [Zhou i in. 2020] \\
\hline \multirow{5}{*}{ Rzadka } & $\begin{array}{l}\text { Ester metylowy kwasu hydroksy- } \\
\text { palmitynowego (PAME - ang. Hydroxyl- } \\
\text { Palmitic Acid Methyl Ester) }\end{array}$ & \multirow[t]{3}{*}{$\begin{array}{l}\text { [Li i Nair 2012, Whiteley } \\
\mathrm{i} \text { in. 2017] }\end{array}$} \\
\hline & $\begin{array}{l}\text { Sygnał chinolonu Pseudomonas (PQS - } \\
\text { ang. Pseudomonas Quinolone Signal) }\end{array}$ & \\
\hline & $\begin{array}{l}\text { Dyfuzyjny czynnik sygnałowy (DSF - ang. } \\
\text { Diffusible Signalling Factor) }\end{array}$ & \\
\hline & Cykliczne dipeptydy & \multirow[t]{2}{*}{ [Li i Nair 2012] } \\
\hline & $\begin{array}{l}\text { Autoinduktory cholery-1 (CAI-1 - ang. } \\
\text { Cholerae Autoinducer-1) }\end{array}$ & \\
\hline
\end{tabular}

Bakterie Gram-dodatnie $\left(\mathrm{G}^{+}\right)$wykorzystują peptydy jako autoinduktory w zjawisku QS (AIP, tab. 1). Peptydy te są syntetyzowane przez rybosomy jako peptydy prekursorowe. Zawierają od 5-17 aminokwasów i ulegają modyfikacjom potranslacyjnym podczas sekrecji, aby się uaktywnić i ustabilizować [Rutherford i Bassler 2012; Verbeke $i$ in. 2017]. U Staphylococcus aureus mają długość 8-9 aminokwasów oraz składają się z pierścieni tiolaktonowych, które zawierają reszty cysteinowe umiejscowione pięć aminokwasów od C końca [Taga i Bassler 2003].

Natomiast u bakterii Gram-ujemnych (G-), przekazywanie sygnałów zachodzi zwykle za pośrednictwem cząsteczek sygnałowych o charakterze laktonów N-acylo-L-homoseryny (ang. AHL - Acyl-Homoserine Lactones). Rdzeń tych cząsteczek stanowi lakton, zaś łańcuchami bocznymi są łańcuchy acylowe o 4-18 atomów węgla [Rutherford i Bassler 2012, Vadakkan i in. 2018]. Przy węglu C3 osadzone są grupy karbonylowe $(-\mathrm{CO})$ i hydroksylowe $(-\mathrm{OH})$ [Rutherford i Bassler 2012]. Występują różne mo- 
dyfikacje laktonu N-acylohomoseryny, tj. 3-hydroksy-AHL i 3-okso-AHL [Whiteley i in. 2017].

Cząsteczkami sygnalizacyjnymi spotykanymi zarówno u bakterii G+ i G- są AI-2, jak i AI-3. Autoinduktor-2 to diester boranu furanozylu. Jego prekursorem jest 4,5-dihydroksy -2,3-glutarodion. Natomiast autoinduktor-3 klasyfikuje się jako pyretroid [Zhou i in. 2020]. W celu oznaczenia ilościowego AI-2 został zaprojektowany szczep reporterowy Vibrio harveyi BB170, który nie posiada autoinduktora AHL i jest pasywny wobec niego oraz nie zawiera autoinduktora-2. Gdy większe stężenie AI-2 zostało wprowadzone do komórki, tym obserwowano silniejszą bioluminescencję [Verbeke i in. 2017].

Kolejnym rodzajem autoinduktora jest ester metylowy kwasu hydroksypalmitynowego, który wpływa na ekspresję czynników wirulencji u bakterii Ralstonia solanacearum [Achari i Ramesh 2015].

Sygnał chinolonu Pseudomonas, inaczej 2-heptylo-3-hydroksyl-4-chinolon modyfikuje profile transkrypcyjne genów, jest inhibitorem wzrostu dla bakterii G+ i G(oprócz Pseudomonas aeruginosa) oraz wykazuje duże powinowactwo do jonów $\mathrm{Fe}^{3+}$, dzięki temu pełni rolę bodźca w ekspresji genów do wytwarzania sideroforów piowerdyny i piocheliny. Żelazo połączone z sygnałem chinolonu Pseudomonas stanowi dobre źródło zapasu dla $P$. aeruginosa $\mathrm{PAO}_{1} \mathrm{w}$ momencie obecności znikomej ilości tego pierwiastka w środowisku [Lin $i$ in. 2018].

Dyfuzyjny czynnik sygnałowy po raz pierwszy został zidentyfikowany u Xanthomonas campestris pv. campestris. Istotną rolę pełni w sygnalizacji wewnątrzgatunkowej, w wytwarzaniu biofilmu oraz odgrywa duże znaczenie w zmniejszeniu lekooporności bakterii. W przeprowadzonych badaniach Deng i in. [2014] udowodnili, że wprowadzenie egzogennego dyfuzyjnego czynnika sygnałowego do komórek Bacillus cereus zmniejsza ich oporność na antybiotyki.

Cykliczne dipeptydy (CDP), inaczej 2,5-diketopiperazyny, występują m.in. u Serratia odorifera [Sun i in. 2020]. Posiadają budowę cykliczną, zbudowane są z pierścienia piperazyny o strukturze sześcioczłonowej, w którym dwa atomy azotu tworzą wiązania amidowe. CDP przyjmują postać różnych izoform, zarówno cis, jak i trans. Pełnią rolę efektorów w quorum sensing oraz metabolitów wtórnych [Bellezza i in. 2019]. Dysponują właściwościami antybakteryjnymi i antywirusowymi, ponadto wykazują aktywność antygrzybiczą i przeciwnowotworową [Sun i in. 2020]. Cykliczne dipeptydy wytwarzane są najczęściej przez bakterie, np. Pseudomonas putida WCS358. Szczep ten produkuje aż cztery cykliczne dipeptydy, które mają predyspozycje do oddziaływań z homologami quorum sensing LuxI i LuxR [Bellezza i in. 2019].

Autoinduktor cholery-1 to (S)-3-hydroksytridekan-4-on, obecny u Vibrio cholerae, który wywołuje cholerę [Kelly i in. 2009]. Bakteria ta używa system m.in. CAI-1/CqsS do kontroli wytwarzania biofilmu oraz czynników zjadliwości [Wei i in. 2011].

\section{Mechanizm działania systemu quorum sensing u bakterii Gram-dodatnich}

Systemy quorum sensing występują zarówno u bakterii Gram-dodatnich, jak i Gram-ujemnych, lecz w niewielkim stopniu mechanizmy ich działania różnią się od siebie. U bakterii $\mathrm{G}+$ wydzielane cząsteczki sygnalizacyjne rozpoznawane są albo przez zewnątrzkomórkowe, związane z błoną kinazy histydynowe dwuskładnikowych systemów sygnalizacyjnych albo też wewnątrzkomórkowo przez cytozolowe regulatory transkrypcji. W zależności od gatunku, nazewnictwo mechanizmów quorum sensing 
może być różne, ze względu na zaangażowane geny i receptory. Na przykład gatunki Staphylococci wykorzystują system Agr quorum sensing, gatunki Streptococci wykorzystują system ComX, natomiast gatunki Bacilli wykorzystują system Rap.

Dwuskładnikowy system regulacyjny składa się z sensorowej kinazy histydynowej (HK) będącej białkiem błonowym oraz z cytoplazmatycznego regulatora odpowiedzi (RR), który po odebraniu sygnału zmienia konformację i reguluje ekspresję docelowego genu. W pierwszym etapie AIP jako pro-peptydy są syntetyzowane na rybosomach, po czym ulegają obróbce potranslacyjnej. Następnie powstają „dojrzałe” peptydy autoindukcyjne [Bhatt 2018]. AIP są wydzielane z komórki przez związany z błoną transporter ABC (ang. ATP - binding cassette). Wraz ze wzrostem gęstości populacji bakteryjnej, AIP gromadzą się w środowisku. Gdy zostanie osiągnięty pewien poziom progowy, związanie AIP z receptorem inicjuje aktywację kinazy receptorowej poprzez fosforylację. Następnie aktywowana kinaza receptorowa przenosi grupę fosforanową na wewnątrzkomórkowy regulator odpowiedzi, który z kolei ulega aktywacji. Wpływa on na transkrypcję specyficznych genów docelowych QS, a także pobudza szlak produkcji peptydów autoindukcyjnych, genów dla kinazy receptorowej, regulatora odpowiedzi oraz genów dla transportera ABC [Rutherford i Bassler 2012, Bhatt 2018]. Po raz pierwszy ten rodzaj szlaku został odkryty u Streptococcus pneumoniae i Latococcus lactis [Bhatt 2018]. System QS pełni funkcję kontrolną w produkcji czynników zjadliwości u bakterii Gram-dodatnich, takich jak gronkowiec złocisty, dwoinka zapalenia płuc, paciorkowiec kałowy, laseczka woskowa i laseczka zgorzeli gazowej [Rutherford i Bassler 2012, Bhatt 2018].

Dwuskładnikowy system QS został dobrze poznany u gronkowca złocistego (Staphylococcus aureus), który jest chorobotwórczy dla ludzi i zwierząt, ponieważ posiada, m.in. czynniki wirulencji. Przyczynia się do powstawania zapalenia płuc i sepsy. Quorum sensing u tego gatunku opiera się na dwuskładnikowym systemie kodowanym przez locus agr [Rutherford i Bassler 2012]. Regulator genu pomocniczego (locus agr) zbudowany jest z białek, tj. AgrA, AgrB, AgrC i AgrD. Właśnie AgrD koduje peptydy autoindukcyjne, następnie to białko ulega proteolizie katalizowanej przez AgrB. Powstaje pośredni związek tio-laktonowy, który ulega uwalnianiu, następnie dochodzi do kolejnej proteolizy. Gdy AIP osiągnie odpowiednie stężenie, wtedy AgrC zostaje pobudzony. Kolejno dochodzi do aktywowania przekaźnika fosforylacji, dzięki któremu następuje wzbudzanie AgrA, zaś białko to działa na RNAII, powodując jego wzrost stężenia i wzrost transkrypcji genów agr. Dochodzi także to transkrypcji RNAIII, która powoduje ekspresję toksyny $\sigma$ i czynników zjadliwości.

U Streptococcus pneumoniae wykorzystywany jest system Com, który składa się $\mathrm{z}$ transportera $\mathrm{ABC}$ przenoszącego peptyd stymulujący kompetencje (17-resztowy peptyd autoindukcyjny). Po osiągnięciu odpowiedniego stężenia pobudza kinazę receptorową do autofosforylacji. Następnie dochodzi do przekazania cząsteczki fosforanowej wewnętrznemu receptorowi regulatorowemu, następuje transkrypcja czynnika $\sigma$, który wykorzystywany jest w transkrypcji genów powiązanych z kompetencją.

Natomiast u Enterococcus faecalis wykryto system Fsr quorum sensing odpowiadający za adhezję do komórek bakteryjnych oraz kontrolę tzw. żelatynazy GeIE. Umożliwia ona rozcięcie składników powierzchniowych, które identyfikują cząsteczki macierzy adhezyjnej i to dzięki nim następuje adhezja do komórek.

Komórki bakterii G+ mogą też posiadać specjalny rodzaj systemu QS, w którym białko receptorowe oddziałuje bezpośrednio z rozpoznanym peptydem sygnalizacyjnym. Receptory te są albo fosfatazami Rap, albo regulatorami transkrypcji i integrują 
rodzinę białek RNPP (od Rap, Npr, PlcR i Prg) [Rocha-Estrada i in. 2010]. Typ ten różni się od pierwszego tym, że $\mathrm{w}$ trakcie osiągnięcia odpowiedniego stężenia peptydy autoindukcyjne przenoszone są przez układ transportera do wnętrza bakterii. Szlak ten opiera się

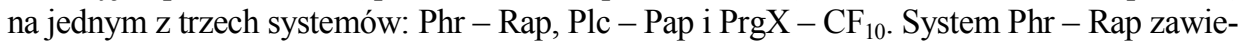
ra pro-peptydy Phr, które transportują sygnał wydzielniczy na $\mathrm{N}$ - końcu, następnie przekazywane są na zewnątrz, gdzie ulegają proteolizie oraz dojrzewaniu. Potem permeaza oligopeptydowa transportuje peptyd Phr do wnętrza bakterii, który może ograniczać działanie Raps (ang. Regulator aspartate phosphatases) i kontrolować ekspresję genów. Natomiast system Plc - Pap posiada PlcR, zapewnia kontrolę czynników zjadliwości u Bacillus cereus oraz ekspresję genu $p l c \mathrm{~A}$ na poziomie transkrypcji. Ostatnim systemem opierającym się na ścieżce samosygnalizowania jest system $\operatorname{PrgX}-\mathrm{CF}_{10}$ występujący u Enterococcus faecalis. Wyróżnia się represorem $\operatorname{PrgX}$, który z łatwością może wiązać peptydy autoindukcyjne [Bhatt 2018].

\section{Mechanizm dzialania systemu quorum sensing u bakterii Gram-ujemnych}

U bakterii Gram-ujemnych występuje odmienny sposób komunikacji pomiędzy sobą, który polega na wykorzystaniu laktonów acylohomoseryny (AHL). Cząsteczki te są produkowane w komórce bakteryjnej, następnie przenoszone przez błony wewnętrzne i zewnętrzne, gdzie wiążą się z receptorami znajdującymi się w cytoplazmie. Następnie dochodzi do regulacji ekspresji genów w regulonie quorum sensing. Czasami identyfikacja AHL może zachodzić za pomocą dwuskładnikowych receptorów kinazy histydynowej, które działają analogicznie do dwuskładnikowych systemów obecnych u bakterii Gram+ [Rutherford i Bassler 2012].

Mechanizm quorum sensing u bakterii Gram-ujemnych został dobrze poznany u morskiej bakterii Vibrio fisheri, u której zjawisko QS zostało po raz pierwszy odkryte jako mechanizm kontrolujący indukcję luminescencji w rosnącej hodowli. U Vibrio fischeri bioluminescencja jest skutkiem ekspresji i reakcji enzymatycznej wywołanej przez lucyferazę, czyli enzymu katalizującego utlenianie lucyferyny [Turovskiy i in. 2007]. Ponadto w szlaku regulatorowym ważną funkcję pełnią geny luxI i luxR kodujące odpowiednio białka LuxI i LuxR [Ling i in. 2019]. LuxR to kinaza sensorowa zawierająca domenę regulatora odpowiedzi. Wewnątrzkomórkowa syntaza autoinduktorów (LuxI) syntetyzuje cząsteczki sygnałowe AHL (3-oxo-C6-HSL, inaczej 3-oxo-AHL) poprzez katalizowanie reakcji pomiędzy S-adenozylometioniną a białkiem nośnika acylowego. Ze względu na niewielkie rozmiary i lipofilność autoinduktorów AHL, łatwo przechodzą one przez błonę komórkową na drodze dyfuzji biernej. Jeśli stężenie AHL jest wystarczająco wysokie, autoinduktor AHL wiąże się z wewnątrzkomórkowym białkiem LuxR i prowokuje domenę wiążącą DNA LuxR do odsłonięcia. Następnie białko LuxR wiąże się z DNA, powodując aktywację transkrypcji genów docelowych, tj. ulega związaniu z promotorem operonu genu luminescencji (lux) i wywołuje zarówno ekspresję lucyferazy, jak i dwóch białek: LuxI i LuxR. Ponad 100 gatunków bakterii Gram-ujemnych posiada system typu LuxI / LuxR z syntazą autoinduktora (np. LuxI) i regulatorem transkrypcji (np. LuxR) [Turovskiy i in. 2007, Verbeke i in. 2017].

Bakterie Vibrio cholerae korzystają z dwóch systemów quorum sensing: AI-2 / LuxPQ i CAI-1 / CqsS, aby kontrolować wytwarzanie biofilmu oraz czynników wirulencji. W pierwszym systemie ważną rolę odgrywa LuxS, ponieważ syntetyzuje prekursor AI-2, produkuje homocysteinę i DPD (ang. 4,5-dihydroxy-2,3-pentanedione), zaś 
DPD bierze udział w wytworzeniu AI-2. Natomiast w drugim systemie CqsA pełni rolę syntazy CAI-1 [Wei i in. 2011].

Kolejną Gram-ujemną bakterią jest Pseudomonas aeruginosa, która posiada cztery szlaki QS, takie jak: podwójny system LuxR / LuxI (LasR / LasI), system RhlR / RhlI, system chinolonów oraz IQS. LasR w połączeniu z 3-okso-C12-HSL pobudzają regulator genów, przede wszystkim gen syntazy lasI, dzięki temu następuje samowzbudzenie. Ponadto wpływa na ekspresje genów, tj. rhlR i rhlI, biorących udział w kodowaniu kolejnego szlaku QS oraz innych genów pqsR i pqsABCDH kodujących system PQS. Natomiast RhlR pełni funkcję kontrolną w ekspresji wirulencji oraz w połączeniu z C4 - HSL działa hamująco na ekspresję genów pqs $\mathrm{R}$ i pqsABCD, co powoduje pobudzenie PQS [Papenfort i Bassler 2016].

\section{Bibliografia}

Achari G.A., Ramesh R. (red.), 2015. Characterization of bacteria degrading 3-hydroxy palmitic acid methyl ester (3OH-PAME), a quorum sensing molecule of Ralstonia solanacearum. Lett. Appl. Microbiol. 60(5), 447-455, https://doi.org/10.1111/lam.12389

Baranowska K., Rodziewicz A. (red.), 2008. Molekularne interakcje w biofilmach bakteryjnych. Kosmos 57(1-2), 29-38.

Bellezza I., Peirce M. J., Minelli A., 2019. Cyclic Peptides in Neurological Disorders: The Case of Cyclo(His-Pro). W: Tommonaro G. (red.), Quorum Sensing. Elsevier Inc. 257-286, https://doi.org/10.1016/b978-0-12-814905-8.00010-1.

Bhatt V.S., 2018. Quorum Sensing Mechanisms in Gram-Positive Bacteria. W: Bramhachari P. V. (red.), Implication of Quorum Sensing System in Biofilm Formation and Virulence. Springer, Singapore, 297-311, https://doi.org/10.1007/978-981-13-2429-1_20.

Czajkowski R., Jafra S. (red.), 2004. Enzymatyczna degradacja laktonów acylo-L-homoseryny i jej potencjalne wykorzystanie w biokontroli i hamowaniu rozwoju infekcji. PAN 2(73), 49-64.

Deng Y., Lim A., Lee J., Chen S., An S., Dong Y.H., Zhang L.-H. (red.), 2014. Diffusible signal factor (DSF) quorum sensing signal and structurally related molecules enhance the antimicrobial efficacy of antibiotics against some bacterial pathogens. BMC Microbiol., 14(51), 2-9, https://doi.org/10.1186/1471-2180-14-51.

Jaworski A., Serwecińska L., Stączek P. (red.), 2005. Quorum sensing - komunikowanie się komórek w populacjach bakterii przy udziale chemicznych cząsteczek sygnałowych. Post. Biol. Kom. 32(2), 231-256.

Kelly R.C., Bolitho M.E., Higgins D.A., Lu W., Ng W.-L., Jeffrey P.D., Rabinowitz J. D., Semmelhack M.F., Hughson F.M., Bassler B.L. (red.), 2009. The Vibrio cholerae quorum-sensing autoinducer CAI-1: analysis of the biosynthetic enzyme CqsA. 5(12), 891-895. https://doi.org/10.1038/nchembio.237.

Li Z., Nair S.K. (red.), 2012. Quorum sensing: How bacteria can coordinate activity and synchronize their response to external signals? Protein Sci. 21(10), 1-15, https://doi.org/10.1002/pro.2132.

Lin J., Cheng J., Wang Y., Shen X. (red.), 2018. The Pseudomonas Quinolone Signal (PQS): Not Just for Quorum Sensing Anymore. Front. Cell. Infect. Microbiol. 8(230), 1-9, https://doi.org/10.3389/fcimb.2018.00230.

Ling J., Zhou L., Wu G., Zhao Y., Jiang T., Liu F. (red.), 2019. The AHL Quorum-Sensing System Negatively Regulates Growth and Autolysis in Lysobacter brunescens. Frontiers in Microbiology, Front Microbiol. 10, 1-13, https://doi.org/10.3389/fmicb.2019.02748.

Papenfort K., Bassler B.L. (red.), 2016.Quorum sensing signal - response systems in Gram-negative bacteria. Nat. Rev. Microbiol. 14(9), 576-588, https://doi.org/10.1038/nrmicro.2016.89. 
Rocha-Estrada J., Aceves-Diez A.E., Guarneros G., de la Torre M. (red.), 2010. The RNPP family of quorum-sensing proteins in Gram-positive bacteria. Appl. Microbiol. Biotechnol. 87(3), 913-923, https://doi.org/10.1007/s00253-010-2651-y.

Rutherford S.T., Bassler B.L. (red.), 2012. Bacterial Quorum Sensing: Its Role in Virulence and Possibilities for Its Control. Cold. Spring Harb. Perspect. Med. 2(11), 1-25, https://doi.org/10.1101/cshperspect.a012427.

Sun S.-J., Liu Y.-C., Weng C.-H., Sun S.-W., Li F., Li H., Zhu H. (red.), 2020. Cyclic Dipeptides Mediating Quorum Sensing and Their Biological Effects in Hypsizygus Marmoreus. Biomolecules 10(298), 1-13, https://doi.org/10.3390/biom10020298.

Taga M.E., Bassler B.L. (red.), 2003. Chemical communication among bacteria. Proc, Natl, Acad. Sci. USA 100(2), 14549-14554, https://doi.org/10.1073/pnas.1934514100.

Turovskiy Y., Kashtanov D., Paskhover B., Chikindas M.L. (red.), 2007. Quorum Sensing: Fact, Fiction, and Everything in Between. Adv. Appl. Microbiol. 62, 191-234, https://doi.org/10.1016/s0065-2164(07)62007-3.

Vadakkan K., Choudhury A.A, Gunasekaran R., Hemapriya J., Vijayanand S. (red.), 2018. Quorum sensing intervened bacterial signaling: Pursuit of its cognizance and repression. J. Genet. Eng. Biotechnol. 16(2), 239-252, https://doi.org/10.1016/j.jgeb.2018.07.001.

Verbeke F., De Craemer S., Debunne N., Janssens Y., Wynendaele E., Van de Wiele C., De Spiegeleer B. (red.), 2017. Peptides as Quorum Sensing Molecules: Measurement Techniques and Obtained Levels In vitro and In vivo. Front. Neurosci. 11(183), 1-18, https://doi.org/10.3389/fnins.2017.00183.

Wei Y., Perez L.J., Ng W.-L., Semmelhack M.F., Bassler B.L. (red.), 2011. Mechanism of Vibrio cholerae Autoinducer-1 Biosynthesis. ACS Chem. Biol. 6(4), 356-365, https://doi.org/10.1021/cb1003652.

Whiteley M. , Diggle S.P, Greenberg E.P. (red.), 2017. Progress in and promise of bacterial quorum sensing research. Nature 551(7680), 313-320, https://doi.org/10.1038/nature24624.

Zhou L., Zhang Y., Ge Y., Zhu X., Pan J. (red.), 2020. Regulatory Mechanisms and Promising Applications of Quorum Sensing - Inhibiting Agents in Control of Bacterial Biofilm Formation. 11 (589640), 1-11, https://doi.org/10.3389/fmicb.2020.589640. 
Damian Jaguszewski $^{1,2}$, Katarzyna Karpińska ${ }^{1}$, Bożena Nowakowicz-Dębek ${ }^{1}$

\section{Natężenie oświetlenia w środowisku pracy nauczyciela języka angielskiego}

Illumination intensity in the work environment of an English teacher

Nauczyciel języka obcego jest zawodem, który kojarzy się z bezpieczną pracą przy biurku. Niestety jednak zawód ten nie jest pozbawiony zagrożeń. Na co dzień dydaktycy mają styczność $\mathrm{z}$ wieloma zagrożeniami, które mogą wywierać negatywny wpływ na ich stan zdrowia. Istotny udział w grupie zagrożeń na tym stanowisku stanowią czynniki fizyczne [Dudek i in. 2004, Terelak 2007]. Istotnym czynnikiem, który może negatywnie oddziaływać na nauczyciela w czasie jego pracy jest jakość oświetlenia. Prowadzanie zajęć edukacyjnych przy niewłaściwych warunkach oświetleniowych uważane jest za czynnik stresowy. Zarówno słabe, jak i zbyt mocne światło wpływa niekorzystnie na pracujące przy nim osoby [Jurgilewicz 2017]. U podstaw dobrego oświetlenia pomieszczenia powinno znajdować się stosowanie odpowiedniej ilości źródeł światła zarówno naturalnego, jak i sztucznego, aby wszystkie parametry oświetlenia były zgodne z aktualnymi normami [Dz. U. 2003 r. Nr 169, poz. 1650]. Pomiary natężenia oświetlenia są pomocne przy tworzeniu nowego i kontrolowaniu już istniejącego systemu świetlnego w szkołach [Górny 2009].

\section{Światlo i jego wpływ na organizm czlowieka}

Światło jest jednym z najważniejszych czynników wywierających wpływ na interakcje człowieka $\mathrm{z}$ otoczeniem. Jest konieczne dla prawidłowego funkcjonowania wzroku, emocjonalnej percepcji oraz prawidłowej oceny otoczenia [Morghen i in. 2009]. Ludzkie oko dzięki swojej budowie przystosowane jest do odbioru promieniowania elektromagnetycznego o długości fal ok. 400-700 nm. Zjawisko to nazywane jest światłem widzialnym [Herman i in. 2002]. Zjawisko padania światła na obiekty w jego zasięgu nazywane jest oświetleniem [PWN - Oświetlenie].

Występowanie sztucznego oświetlenia na stanowiskach pracy ma za zadanie ułatwiać poruszanie się i zapewniać warunki oświetleniowe odpowiednio dostosowane do wykonywanych zadań. Wyodrębnia się trzy główne rodzaje oświetlenia w zakładach pracy:

- oświetlenie ogólne - zapewnia równomierne oświetlenie danego pomieszczenia;

- oświetlenie miejscowe - zapewnia dodatkowe oświetlenie obszaru, gdzie wykonywana jest praca wzrokowa, ma na celu wzmocnienie oświetlenia miejsca pracy;

\footnotetext{
${ }^{1}$ Uniwersytet Przyrodniczy w Lublinie, Wydział Nauk o Zwierzętach i Biogospodarki, Katedra Higieny Zwierząt i Zagrożeń Środowiska

${ }^{2}$ damian0202vp@gmail.com
} 
- oświetlenie złożone - jest to kombinacja wykorzystywania oświetlenia ogólnego razem z oświetleniem miejscowym;

Światło jest ważną składową środowiska życia człowieka. Kontakt z nim ułatwia wykonywanie podstawowych czynności i zwiększa poczucie bezpieczeństwa. Naturalnym źródłem światła jest słońce. W środowisku pracy dodatkowo wykorzystywane są sztuczne źródła światła. Każdy człowiek funkcjonuje według własnego wewnętrznego zegara biologicznego, który reguluje zachodzące w jego organizmie procesy. Do utrzymania prawidłowego rytmu pracy, potrzebuje on zarówno światła, jak i ciemności w odpowiednich proporcjach. W zależności od natężenia światła docierającego do człowieka, produkcja hormonów jest regulowana przez rytm zegara. Podstawowymi hormonami, których liczebność się zmienia w zależności od ilości światła są melatonina i kortyzol [Skwarło-Sońta 2014].

Melatonina jest hormonem sterującym rytmem spoczynku i aktywności człowieka, natomiast kortyzol pobudza do działania, umożliwia człowiekowi bycie aktywnym, zmniejsza znużenie, poprawia nastrój. Hormony te odgrywają ważną rolę w zarządzaniu czujnością i snem [Szewczyk i in. 2018].

\section{Oświetlenie w pracy}

Możliwość zaprojektowania i użytkowania sztucznego oświetlenia pozwala wykonywać pracę przez całą dobę. Zapewnia ono dobrą widoczność i poczucie bezpieczeństwa nawet w środku nocy. Rozwiązanie to zwiększa wydajność wielu zakładów pracy, które wykorzystują pracę zmianową [Gaston i in. 2015].

Poprawne działanie zmysłu wzroku i zdolności widzenia znacząco oddziałuje na tok i wydajność pracy. Właściwie oświetlone stanowisko pracy gwarantuje odpowiednie warunki do wykonywania zadań wzrokowych. Pozwala unikać powstawania błędów i usprawnia pracę. Nieodpowiednie oświetlenie lub stanowisko zbyt oddalone od źródła światła zmusza pracownika do wytężonej pracy wzrokowej. Przyczynia się to do szybkiego zmęczenia narządu wzroku, a w konsekwencji do zwiększenia liczby pomyłek i wzrostu zdarzeń potencjalnie wypadkowych [Gembalska-Kwiecień 2013].

Na całokształt oświetlenia znajdującego się w zakładach pracy składa się oświetlenie ogólne, miejscowe, a także oświetlenie awaryjne używane w wyjątkowych sytuacjach. Oświetlenie to ma na celu zapewnić bezpieczeństwo w razie zaniku zasilania podstawowego. W tym celu instalacja oświetlenia awaryjnego powinna posiadać swoje niezależne zasilanie [Pawlak 2006]. Obowiązek stosowania tego oświetlenia reguluje rozporządzenie Ministra Spraw Wewnętrznych i Administracji z dnia 7 czerwca 2010 r. w sprawie ochrony przeciwpożarowej budynków, innych obiektów budowlanych i terenów [Dz.U. 2010 nr 109 poz. 719]. Dodatkowo norma omawiająca oświetlenie awaryjne dzieli je na oświetlenie ewakuacyjne oraz oświetlenie zapasowe [PN-EN 1838:2005].

- oświetlenie ewakuacyjne - oświetla pomieszczenia, w szczególności drogi ewakuacyjne. Umożliwia bezpieczne opuszczenie budynku w sytuacjach, gdy awaryjna spowoduje wyłączenie podstawowego oświetlenia;

- oświetlenie zapasowe - zapewnia odpowiednie warunki do kontynuowania pracy w sytuacjach nagłego zaniku zasilania podstawowego.

Oświetleniem rzadziej spotykanym, ale bardzo pomocnym w niektórych gałęziach przemysłu jest oświetlenie dodatkowe. Wykorzystane jest w pomieszczeniach, gdy przez wzgląd na specyficzny proces technologiczny praca wykonywana jest bez włą- 
czonego oświetlenia podstawowego. Oświetlenie to umożliwia pracownikom bezpieczne przemieszczanie się po obiekcie [Boryń 2013].

\section{Parametry oświetlenia}

Tworzenie środowiska świetlnego na danym stanowisku czy eksploatacja już istniejącego nie może obejść się bez przeprowadzania pomiarów oświetleniowych. To na podstawie otrzymanych wyników powinno się podejmować działania eksploatacyjne oraz decydować o przyszłych wymianach konkretnych elementów. Do prawidłowego wykonania pomiarów konieczna jest wiedza na temat oświetlenia oraz jego parametrów [Strzyżewski 2017].

Parametrami określającymi oświetlenie są:

- natężenie oświetlenia - definiowane jest przez ilość światła docierającego do przyjętego punktu na danej płaszczyźnie; jednostką opisującą natężenie jest luks [Heim i in. 2010];

- równomierność oświetlenia - jest to iloraz najmniejszej wartości natężenia oświetlenia odnotowanej na płaszczyźnie do średniego natężenia oświetlenia tej płaszczyzny [Uzarczyk 2006];

- wskaźnik oddawania barw - określa jak bardzo kolor oświetlonego obiekt jest zgodny z kolorem tego przedmiotu oświetlanego światłem odniesionym w konkretnych warunkach; podawany jest w skali 0-100; światła zapewniające wartość tego parametru zbliżone do 100 charakteryzują się najlepszymi właściwościami;

- temperatura barwowa - odnosi się do barwy światła emitowanego przez źródła światła; podawana jest w kelwinach; źródła światła ze względu na ich temperatury barwowe można podzielić na trzy grupy: ciepła, naturalna i zimna [Majka 2005];

- rozkład luminancji - określa stopień rozkładu jaskrawości obserwowanego obszaru; zarówno zbyt mały, jak i zbyt duży poziom luminancji może pływać negatywnie na człowieka;

- ograniczenie olśnienia - parametr zajmujący się zjawiskiem olśnienia, które jest spowodowane niewłaściwym rozkładem luminancji; olśnienie pod względem skutków dzieli się na przeszkadzające, przykre i oślepiające; parametr ten ma na celu niwelowanie tego efektu i jego skutków [Heim i in. 2010];

- migotanie - to wrażenie wzrokowe spowodowany światłem, którego luminancja jest zmienna w czasie [Pawlak 2004];

- efekt stroboskopowy - to spowodowane migotaniem wrażenie wzrokowe, które wywołuje u człowieka złudzenie bezruchu elementów, które w istocie są w ciągłym ruchu [Bullough i in. 2011].

\section{Norma dotycząca oświetlenia}

Stosowanie odpowiednio dostosowanego oświetlenia jest podstawą bezpiecznej i wydajnej pracy. Główną normą omawiającą oświetlenie jest PN-EN 12464-1:2012. Zawarte w niej są opisy parametrów oświetlenia, sposoby wykonywania pomiarów, a także sposoby interpretacji wyników. Norma ta opisuje także wartości parametrów oświetleniowych dla konkretnych stanowisk oraz rodzajów czynności. Najważniejszą częścią normy są tabele zawierające wartości, do których należy się odnosić podczas analizy wyników i wy- 
konywania pomiarów oświetlenia. W tabeli 1 zamieszczone zostały wybrane wymagania oświetleniowe dla przykładowych pomieszczeń znajdujących się w szkole. Natomiast w tabeli 2 pokazano zależność wartości natężenia oświetlenia w polu zadania do wartości natężenia oświetlenia w polu bezpośredniego otoczenia [PN EN 12464-1:2012].

Tabela 1. Wymagania oświetleniowe dla pomieszczeń szkolnych [PN-EN 12464-1:2012]

\begin{tabular}{|c|c|c|c|c|c|}
\hline $\begin{array}{c}\text { Typ obszaru, zadanie lub } \\
\text { działalność }\end{array}$ & $\begin{array}{c}\mathrm{E}_{\mathrm{m}} \\
{[\mathrm{lx}]}\end{array}$ & $\begin{array}{c}\mathrm{UGR}_{\mathrm{L}} \\
-\end{array}$ & $\mathrm{U}_{\mathrm{o}}$ & $\mathrm{R}_{\mathrm{a}}$ & $\begin{array}{l}\text { Wymagania } \\
\text { specyficzne }\end{array}$ \\
\hline $\begin{array}{l}\text { Klasy, pokoje } \\
\text { do samodzielnej nauki }\end{array}$ & 300 & 19 & 0,6 & 80 & $\begin{array}{l}\text { zaleca się, aby oświe- } \\
\text { tlenie było sterowane }\end{array}$ \\
\hline Pokoje nauczycielskie & 300 & 19 & 0,6 & 80 & \\
\hline $\begin{array}{l}\text { Pokoje do magazynowania } \\
\text { materiałów dydaktycznych }\end{array}$ & 100 & 25 & 0,4 & 80 & \\
\hline Biblioteki: obszary do czytania & 500 & 19 & 0,6 & 80 & \\
\hline Laboratorium językowe & 300 & 19 & 0,6 & 80 & \\
\hline \multicolumn{6}{|c|}{$\begin{array}{l}\mathrm{E}_{\mathrm{m}}-\text { eksploatacyjne natężenie oświetlenia } \\
\mathrm{UGR}_{\mathrm{L}}-\text { olśnienie przykre } \\
\mathrm{U}_{\mathrm{o}}-\text { równomierność natężenia oświetlenia } \\
\mathrm{R}_{\mathrm{a}}-\text { wskaźnik oddania barw }\end{array}$} \\
\hline
\end{tabular}

Tabela 2. Powiązanie natężeń oświetlenia na obszarach zadań i natężeń oświetlenia na obszarach bezpośredniego otoczenia [PN EN 12464-1:2012]

\begin{tabular}{|c|c|}
\hline $\begin{array}{c}\text { Natężenie oświetlenia } \\
\text { na obszarze zadania } \\
E_{\max }[1 \mathrm{x}]\end{array}$ & $\begin{array}{c}\text { Natężenie oświetlenia na obszarze } \\
\text { bezpośredniego otoczenia }[\mathrm{xx}]\end{array}$ \\
\hline 750 & 500 \\
300 & 300 \\
200 & 200 \\
150 & 150 \\
100 & $E_{\text {task }}$ \\
$\leq 50$ & $E_{\text {task }}$ \\
& $E_{\text {task }}$ \\
\hline
\end{tabular}

Celem pracy były analiza i ocena natężenia oświetlenia w środowisku pracy nauczyciela języka angielskiego.

\section{Material i metody badań}

Pomiary przeprowadzono, opierając się na Polskiej Normie PN-EN 12464-1:2012. Pomiary natężenia oświetlenia wykonane zostały w budynku szkoły publicznej na terenie miasta Ostrowca Świętokrzyskiego. Pomieszczenie objęte pomiarem było salą dydaktyczną, pełniącą $\mathrm{w}$ tej szkole funkcje laboratorium językowego. Wymiary omawianej sali wynosiły 7,5 × 7,5 m, a jej wysokość to $4 \mathrm{~m}$. 
Przedmiotem badań był pomiar oświetlenia i określenie jego natężenia w sali dydaktycznej. Instalacja oświetleniowa zamontowana w tym pomieszczeniu składała się z 7 opraw oświetleniowych. Wszystkie oprawy pochodziły od jednego producenta i posiadały ten sam model - NOTUS 3 EVG. Oprawy zamontowane były na wysokości $4 \mathrm{~m}$. Odległość od opraw do blatów ławek wynosiła 3,1 m. W każdej z opraw umieszczone były po dwie świetlówki firmy PIŁA-PHILIPS i oznaczeniu S36W/865 T8. Pojedyncza świetlówka wg deklaracji producenta charakteryzowała się mocą $36 \mathrm{~W}$, temperaturą barwową $5000 \mathrm{~K}$ i współczynnikiem oddawania barw $\mathrm{R}_{\mathrm{a}}=80$.

Do wykonania pomiarów użyto luksomierza szwajcarskiej firmy ELBRO o modelu ELX-2111. Przygotowanie do pomiarów rozpoczęto od dokładnego zwymiarowania pomieszczenia. Znając jego wymiary wydzielono w nim odpowiednie obszary, konieczne do dalszych czynności:

- pole zadania - obszar w obrębie, którego nauczyciel wykonuje zadania wzrokowe; objął on swoim zasięgiem ławki, biurko nauczyciela oraz przestrzeń między nimi; pole zadania określone zostało na wysokości blatów ławek, tzn. $80 \mathrm{~cm}$ od powierzchni podłogi; wymiary wyznaczonego pola to: $430 \mathrm{~cm} \times 450 \mathrm{~cm}$;

- pole bezpośredniego otoczenia - pas znajdujący się w polu widzenia; jego szerokości określono na $0,5 \mathrm{~m}$; przylegał on bezpośrednio do pola zadania; obszar ten tak jak pole zadania znajdował się na wysokości blatów ławek.

Po wyznaczeniu obszarów w sali dydaktycznej przystąpiono do określenia liczby punktów pomiarowych oraz ich równomiernego rozmieszczenia. Wyznaczanie liczby oczek siatki, a zarazem liczby punktów pomiarowych, zaczęto od skorzystania ze wzoru na maksymalny wymiar oczka siatki:

$$
p=0,2 * 5^{\log (d)}
$$

gdzie:

$\mathrm{p}$ - maksymalny wymiar oczka siatki [m]

$\mathrm{d}$ - dłuższy wymiar obliczanego obszaru [m].

Obliczony maksymalny wymiar oczka siatki wyniósł $0,58 \mathrm{~m}$. Następnie dzieląc obydwa wymiary pola zadania przez tą wartość i zaokrągleniu wyniku do liczby całkowitej otrzymano liczby kolumn i wierszy. Po wykonaniu obliczeń otrzymano siatkę składającą się z 8 kolumn i 8 wierszy. Wiedząc, że w centrum każdego oczka siatki powinien znajdować się jeden punkt, ustalono liczbę punktów na 64. Znając liczbę punktów, rozmieszczono je równomiernie w polu zadania. Dodatkowo w celu późniejszej analizy wyznaczono punkty w polu bezpośredniego otoczenia.

Pomiary skupiły się na badaniu sztucznego oświetlenia występującego w badanej sali. W celu zniwelowania wpływu oświetlenia naturalnego na wyniki pomiarów, odbyły się one w godzinach wieczornych przy zasłoniętych oknach. Pomiary odbyły się po wstępnym wyżarzeniu świetlówek.

Następnie przystąpiono do zasadniczej części pomiarów, którą było zmierzenie natężenia oświetlenia. Polegał on na umieszczaniu głowicy luksomierza w 81 wcześniej wyznaczonych punktach pomiarowych i zanotowaniu wskazanych wartości. Przy czym pomiar obejmował punkty znajdujące się zarówno w polu zadania (64 punkty), jak i polu bezpośredniego otoczenia (17 punktów).

Zanotowane podczas wykonywania pomiarów wyniki pozwoliły wyliczyć wartości dodatkowych parametrów oświetlenia. W tym celu wykorzystano poniższe wzory: 
- średnie natężenia oświetlenia

$$
E_{\text {s } r}=\frac{\left(E_{1}+E_{2}+\cdots+E_{n}\right)}{n}
$$

gdzie:

$\mathrm{E}_{\mathrm{sr}}$ - wartość średniego natężenia oświetlenia płaszczyźnie,

$\mathrm{n}$ - liczba punktów pomiarowych,

$\mathrm{E}_{1}, \mathrm{E}_{\mathrm{n}}-$ wyniki pomiarów w kolejnych punktach pomiarowych;

- równomierność oświetlenia

$$
U_{o}=\frac{E_{\min }}{E_{s} r}
$$

gdzie:

$\mathrm{U}_{\mathrm{o}}$ - równomierność oświetlenia,

$\mathrm{E}_{\min }$ - najmniejsza zmierzona wartość natężenia oświetlenia występująca na danej płaszczyźnie,

$\mathrm{E}_{\mathrm{sr}}$ - średniego natężenia oświetlenia na tej płaszczyźnie.

\section{Wyniki badań i ich analiza}

Wyniki z wykonanych pomiarów i rozkład poszczególnych punktów na rycinie 1 .

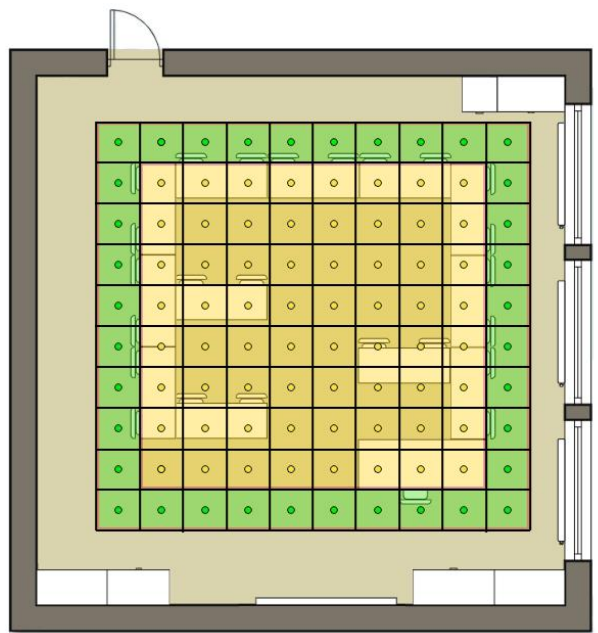

\begin{tabular}{|l|l|l|l|l|l|l|l|l|}
\hline 160 & 155 & 158 & 160 & 165 & 155 & 157 & 155 & 152 \\
\hline 220 & 250 & 239 & 260 & 260 & 259 & 260 & 261 & 192 \\
\hline 217 & 290 & 300 & 302 & 315 & 300 & 303 & 300 & 209 \\
\hline 222 & 280 & 302 & 310 & 330 & 315 & 317 & 299 & 188 \\
\hline 230 & 285 & 312 & 305 & 315 & 320 & 315 & 305 & 255 \\
\hline 228 & 295 & 315 & 302 & 330 & 329 & 315 & 324 & 230 \\
\hline 171 & 285 & 302 & 335 & 370 & 370 & 354 & 305 & 250 \\
\hline 161 & 230 & 300 & 343 & 333 & 340 & 298 & 253 & 220 \\
\hline 150 & 165 & 203 & 219 & 201 & 200 & 192 & 180 & 175 \\
\hline
\end{tabular}

Ryc. 1. Rozkład natężenia oświetlenia w poszczególnych punktach badanej sali [lx] (fot. własna)

Po zebraniu wszystkich danych można stwierdzić, że zmierzone wartości oscylowały w przedziale: w polu zadania $230 \mathrm{~lx}-370 \mathrm{~lx}$, w polu bezpośredniego otoczenia 150 lx - 255 lx. Średnie wartość natężenie oświetlenia wyniosła odpowiednio: w polu 
zadania 303 lx, w polu bezpośredniego otoczenia 190 lx. Równomierność natężenia oświetlenia: polu zadania 0,76 , polu bezpośredniego otoczenia 0,78 .

Przeprowadzone badania skupiały się na kluczowych parametrach oświetlenia. Otrzymana wartość średniego natężenia oświetlenia dla pola zadania przewyższyła minimalny poziom wymagany dla takich pomieszczeń. Czynnik ten zmierzony dla pola bezpośredniego otoczenia okazał się niewystarczający, ponieważ jego wartość nie osiągnęła wartości minimalnej.

Obliczona równomierność natężenia oświetlenia zarówno dla pola zadania, jak i pola bezpośredniego otoczenia osiągnęła, a nawet przekroczyła minimalne wartości zalecane w tym przypadku. Wyniki wskazują na to, że światło jest miarowo rozprowadzane na obszarze badań.

Wykorzystywane $\mathrm{w}$ badanym pomieszczeniu źródła światła zapewniały poziom temperatury barwowej oraz współczynnik oddawania barw spełniający wymagania normy dla laboratoria językowego.

\section{Podsumowanie i wnioski}

Przeprowadzone badania wykazały, że minimalne wartości dla objętych badaniami parametrów zostały osiągnięte w prawie każdym punkcie. Jedynym odstępstwem okazało się średnie natężenie oświetlenia w polu bezpośredniego otoczenia. Jego wartość była bliska wymaganej minimalnej wielkości. Przez wzgląd na fakt, iż zajęcia w badanej sali odbywają się tylko w ciągu dnia, kiedy oświetlenie sztuczne jest wspomagane przez oświetlenie naturalne można uznać występującą w tym pomieszczeniu instalację oświetleniową za odpowiednią.

Przeprowadzone badania i analiza wyników pozwoliły na postawienie następujących wniosków:

1. średnia wartość natężenia oświetlenia w polu zadania wynosi 303 lx i wielkość ta spełnia wymagania normy;

2. natężenie oświetlenia w polu bezpośredniego otoczenia nie osiągnęła minimalnych wymagań zapisanych w normie;

3. warunki oświetleniowe, w których przebywa nauczyciel można uznać za odpowiednie, gdyż stanowisko pracy jest doświetlane światłem naturalnym.

\section{Bibliografia}

Boryń H., 2013. Aktualne przepisy i normy dotyczące oświetlenia awaryjnego, Zesz. Nauk. Wydz. Elektrotechniki i Automatyki Polit. Gdańskiej Nr 35.

Bullough J.D., Hickcox K.S., Klein T.R., Lok A., Narendran N., 2011. Detection and acceptability of stroboscopic effects from flicker, Lighting Res. Technol. 44, 4, 477-483.

Dudek B., Waszkowska M., Merecz D., Hanke W., 2004. Ochrona zdrowia pracowników przed skutkami stresu zawodowego, Inst. Med. Pracy, Łódź.

Gaston K. J., Gaston S., Bennie J., Hopkins J., 2015. Benefits and costs of artificial night time lighting of the environment, Environ. Rev. 23, 14-23.

Gembalska-Kwiecień A., 2013. Prawidłowe kształtowanie środowiska pracy jako jeden z elementów podnoszenia bezpieczeństwa pracy, Systemy Wspomagania w Inż. Prod. 3 (5), 95-108. 
Górny A., 2009. Kształtowanie warunków oświetleniowych jako czynnika minimalizacji uciążliwości pracy. W: Charytonowicz (red.), Wybrane kierunki badań ergonomicznych w 2009 roku, Wyd. PTErg, Oddział we Wrocławiu, Wrocław, 59-70, 2.

Heim D., Jędrzejuk H., Szczepańska E., 2010. Metody określania parametrów oświetlenia dziennego dla potrzeb optymalizacji wielokryterialnej budynków mieszkalnych - komfort wizualny, Fizyka budowli w teorii i praktyce, V, 3, 5-8.

Herman M. A., Palestyński A., Widomski L., 2002. Podstawy fizyki. PWN, Warszawa.

Jurgilewicz O., 2017.Stres i stresory w pracy wpływające na poczucie bezpieczeństwa pracownika, Modern Manag. Rev. 24 (4), 59-71.

Majka M., 2005. Oświetlenie miejsc pracy, Atest Ochrona Pracy, 8, 24-25.

Morghen I., Turola M.C., Forini E., Di Pasquale P., Zanatta P., Matarazzo T., 2009. Ill-lighting syndrome: prevalence in shift-work personnel in the anaesthesiology and intensive care department of three Italian hospitals, J. Occup. Med. Toxicol. 4, 6.

Obwieszczenie Ministra Gospodarki, Pracy i Polityki Społecznej z dnia 28 sierpnia 2003 r. w sprawie ogłoszenia jednolitego tekstu rozporządzenia Ministra Pracy i Polityki Socjalnej w sprawie ogólnych przepisów bezpieczeństwa i higieny pracy (Dz. U. 2003 r. Nr 169, poz. 1650).

Oświata i wychowanie w roku szkolnym 2018/2019, Główny Urząd Statystyczny w Gdańsku, Warszawa, Gdańsk 2019.

Pawlak A., 2004. Oświetlenie miejsc pracy we wnętrzach - nowa norma oświetleniowa, Bezpieczeństwo pracy 10.

Pawlak A., 2006. Oświetlenie awaryjne wymagania, Bezpieczeństwo pracy 6.

PN-EN 12464-1:2012, Światło i oświetlenie - Oświetlenie miejsc pracy, część 1., Miejsca pracy we wnętrzach.

PN-EN 1838:2005, Zastosowanie oświetlenia. Oświetlenie awaryjne.

PWN, 1997-2020, Oświetlenie, Encyklopedia PWN, https://encyklopedia.pwn.pl/haslo/oswietlenie;4652790.html [dostęp: 27.11.2020].

Rozporządzenie Ministra Spraw Wewnętrznych i Administracji z dnia 7 czerwca 2010 r. w sprawie ochrony przeciwpożarowej budynków, innych obiektów budowlanych i terenów (Dz.U. $2010 \mathrm{nr} 109$ poz. 719 ).

Skwarło-Sońta K., 2014. Funkcjonowanie zegara biologicznego człowieka w warunkach skażenia światłem, Prace i Studia Geograficzne, 53, 129-144.

Strzyżewski J., 2017. Pomiary parametrów oświetleniowych we wnętrzach, Czasop. Elektroinstalator, Wyd. SIGMA-NOT, 46-51.

Szewczyk P.B., Dziuba A.M., Poniewierka E., 2018. Melatonina - metabolizm i rola hormonu szyszynki, Pielęgniarstwo i Zdrowie Publiczne, 8, 2, 135-139.

Terelak J.F., 2007. Stres zawodowy. Charakterystyka psychologiczna wybranych zawodów stresowych, Wyd. UKSW, Warszawa.

Uzarczyk A., 2006. Czynniki szkodliwe i uciążliwe w środowisku pracy, ODDK, Gdańsk. 
Martyna Jarosz ${ }^{1}$, Weronika Głowienka ${ }^{1,3}$, Monika Stoma ${ }^{2}$

\section{Ocena świadomości ekologicznej mieszkańców Lubelszczyzny}

Evaluation of environmental awareness of the Lublin region inhabitants

W XXI w. każdy powinien zdać sobie sprawę, że jedną z priorytetowych spraw jest dbanie o środowisko, które ulega szybkiej degradacji. Ludzie zobowiązani są do działania, by nie dopuścić do dewastacji ekosystemu. Są oni głównym determinantem niszczącym je - odpowiadają bowiem za większość negatywnych działań wobec środowiska. Należy zwrócić więc szczególną uwagę na działania proekologiczne, które przynoszą korzyści dla następnych pokoleń. Działania te mogą być podejmowane na szczeblu centralnym, np. przez rządy poszczególnych krajów, agencje pozarządowe, a nawet na szczeblu globalnym. Jednakże szczególnie istotne wydają się być działania indywidualne, podejmowane przez mieszkańców danego obszaru czy regionu.

W związku z powyższym, w celu oceny świadomości ekologicznej mieszkańców Lubelszczyzny przeprowadzono badania przy użyciu autorskiego kwestionariusza ankietowego. Uzyskane wyniki przedstawiono w formie opisowej i graficznej. Na ich podstawie zostały wyciągnięte wnioski w badanej problematyce.

\section{Ekologia, ochrona środowiska i świadomość ekologiczna}

Ekologia (grec. oikos - dom, miejsce życia, logos - słowo, nauka) to nauka zajmująca się badaniem relacji (współzależności) między organizmami żywymi i ich środowiskiem, z uwzględnieniem wzajemnych stosunków między tymi organizmami. Ekologia jest nauką interdyscyplinarną wykorzystującą wiedzę z dziedzin takich jak: zoologia, genetyka, botanika czy ewolucjonizm [Szpunar 2014].

Ochrona środowiska to z kolei ogół działań, które człowiek wdraża na rzecz dbania o zachowanie w jak najlepszym stanie środowiska przyrodniczego. To nie tylko naprawianie szkód będących wynikiem działań człowieka, ale również działania związane z zapobieganiem ich powstawania. W Polsce obowiązuje Ustawa z dnia 27 kwietnia 2001 r. Prawo ochrony środowiska. Określa ona zasady ochrony środowiska oraz warunki korzystania z jego zasobów, z uwzględnieniem wymagań zrównoważonego rozwoju [Dz.U. $2001 \mathrm{nr} 62$ poz. 627, Gruszecki 2011].

Świadomość ekologiczna oznacza natomiast relację człowiek - środowisko. W skład tego pojęcia wchodzi wiedza, wyobraźnia ekologiczna i system wartości, w którym „być” jest ponad „mieć”. Człowiek w tej relacji powinien cechować się odpowiedzialnością za stan środowiska przyrodniczego. Świadomość ekologiczna objawia się sza-

\footnotetext{
${ }^{1}$ Uniwersytet Przyrodniczy w Lublinie, Wydział Inżynierii Produkcji

${ }^{2}$ Uniwersytet Przyrodniczy w Lublinie, Zakład Logistyki i Zarządzania Przedsiębiorstwem

${ }^{3}$ weronika_glowienka@wp.pl
} 
cunkiem do przyrody, dbaniem o nią i przestrzeganiem zasad ochrony środowiska. Pozwala na dostrzeżenie różnic pomiędzy pojęciami ekologiczny i „konwencjonalny” oraz pozwala nam świadomie ocenić wpływy przemysłu, rolnictwa na środowisko i zdrowie człowieka [Tuszyńska 2013].

Wyróżnić można następujące poziomy świadomości ekologicznej:

- intuicyjne przekonanie o zagrożeniu danego elementu ekosystemu,

- połączenie intuicji z wiedzą o zagrożeniach,

- reakcja emocjonalna powodująca działanie [Sobczyk 2003].

\section{Rolnictwo ekologiczne a konwencjonalne}

Początki rolnictwa ekologicznego w Polsce, czyli historia pierwszego gospodarstwa ekologicznego sięga roku 1931, kiedy to hrabia Stanisław Karłowski, w majątku w Szelejewie o powierzchni 1760 ha, wprowadził metodę biodynamiczną. Następnie powstało Towarzystwo Krzewienia Zasad Życia i Gospodarki Zgodnie z Przyrodą. Popularyzacja tego rodzaju rolnictwa była rozwijana poprzez wprowadzenie kursów oraz szkoleń dla rolników; do dalszego rozwoju tej dziedziny przyczyniły się liczne dofinasowania do gospodarstw o profilu ekologicznym oraz przystąpienie Polski do Unii Europejskiej [Żelezik 2009, Ducka 2011, Domagalska i Buczkowska 2015].

Podstawowym aktem prawnym dotyczącym rolnictwa ekologicznego, w sprawie produkcji ekologicznej i znakowania produktów jest ustawa z dnia 25 czerwca $2009 \mathrm{r}$. o rolnictwie ekologicznym [Dz. U. 2009 nr 116 poz. 975 ]. Głównym założeniem rolnictwa ekologicznego jest odrzucenie środków chemii rolnej oraz weterynaryjnej. Zamiast tych środków, w celu poprawy żywotności roślin, stosuje się nawozy naturalne, np. obornik czy kompost. Układ ten charakteryzują niskie nakłady finansowe oraz śladowe zużycie energii, dążenie do samowystarczalności paszowo-nawozowej (zamknięcie obiegu materii), a także dbałość o warunki bytowe zwierząt gospodarczych. System gospodarowania ekologicznego, oprócz zaspokajania potrzeb konsumenckich, ma również na celu działania dotyczące ochrony środowiska, utrzymanie równowagi biologicznej czy podniesienie żyzności gleby, np. poprzez stosowanie płodozmianu. Rolnictwo ekologiczne ukierunkowane jest przede wszystkim na dobrą jakość produktów [Tyburski i Żakowska-Biemans 2007, Runowski 2009]

Rolnictwo konwencjonalne to system gospodarowania polegający na maksymalizacji zysków osiągniętych poprzez sterowanie i stymulowanie upraw środkami chemicznymi, stosując nawozy mineralne, biocydy, syntetyczne regulatory wzrostu oraz inne nowoczesne środki produkcji pochodzenia biologicznego, chemicznego, mechanicznego czy elektronicznego. Charakteryzuje się ono małymi nakładami robocizny na rzecz zwiększenia udziałów w produkcji przemysłowych środków. Dzięki temu systemowi jesteśmy w stanie wyprodukować znacznie więcej - co oznacza maksymalizację plonów [Kostecka i Mroczek 2007, https://zycierolnika.pl]. Niestety konwencjonalne rolnictwo niesie za sobą wiele zagrożeń, przede wszystkim wzrost zanieczyszczenia środowiska. Kolejnymi negatywnymi czynnikami są: pogorszenie jakości żywności, spadek żyzności gleby, osłabienie zdolności samoregulujących ekosystem, przenikanie substancji chemicznych do wód gruntowych, co w konsekwencji może mieć szkodliwy wpływ na zdrowie ludzi i zwierząt. Nasilenie stosowania pestycydów niesie za sobą ponadto ograniczenie występowania owadów nie tylko szkodliwych, ale także owadów zapylających, bądź uodpornienie się szkodników [Dubas 2007, Zawada 2016, Iwanicki 2017]. 


\section{Dyrektywa plastikowa}

Plastik jest obecny wszędzie, w każdej dziedzinie naszego życia. Należy zwrócić uwagę na jego negatywne oddziaływanie na środowisko. Dlatego właśnie została wprowadzona w życie dyrektywa dotycząca zakazu używania tworzyw sztucznych jednorazowego użytku. Główne cele dyrektywy są następujące [Dz.U. L 155 z 12.6.2019]:

- zapobieganie i zmniejszenie wpływu niektórych produktów z tworzyw sztucznych na środowisko,

- zachęcanie do przechodzenia na gospodarkę w obiegu zamkniętym,

- zmniejszenie stosowania produktów z tworzyw sztucznych,

- wprowadzenie zasady ,zanieczyszczający płaci”,

- obowiązkowe oznakowanie na niektórych produktach jednorazowego użytku z tworzyw sztucznych,

- upowszechnienie wiedzy na temat produktów z tworzyw sztucznych.

Wśród najważniejszych założeń dyrektywy plastikowej należy niewątpliwie wymienić:

- od 2021 r. zakaz wprowadzania do obrotu 10 plastikowych produktów jednorazowego użytku - patyczki higieniczne, sztućce (widelce, noże, łyżki, pałeczki), talerze, słomki, mieszadełka do napojów, patyczki do balonów, pojemniki do żywności i styropianowe kubeczki;

- od 2025 r. nakrętki i wieczka plastikowe będzie można wprowadzić do obrotu tylko pod warunkiem, że będą one przymocowane na stałe do butelek i pojemników;

- od 2025 r. wszystkie butelki plastikowe muszą być wykonane w minimum 25\% z materiału pochodzącego z recyklingu, a od 2030 r. - w $30 \%$;

- do 2025 r. poziom zbiórki i recyklingu plastikowych butelek na napoje jednorazowego użytku ma wynieść 77\%, a do 2029 r. - 90\% [WWF 2020].

Wdrożenie dyrektywy we wszystkich państwach Unii Europejskiej zaplanowano na 3 lipca 2021 r. Podobnie jak przepisy dotyczące ograniczeń w zakresie wprowadzania do obrotu i znakowania. Natomiast środki w dziedzinie rozszerzonej odpowiedzialności producenta mają zastosowanie od dnia 31 grudnia 2024 r. [Dz.U. L 155 z 12.6.2019, Tekiela i in. 2020].

\section{Analiza badań „oceny świadomości ekologicznej mieszkańców Lubelszczyzny”}

W celu oceny świadomości ekologicznej mieszkańców Lubelszczyzny przeprowadzona została ankieta, w której wzięło udział 238 osób. W badaniu brały udział głównie kobiety, stanowiły one aż 81,9\% ogółu respondentów; pozostałą część stanowili mężczyźni. Ankietowani to były głównie osoby w przedziale wiekowym 18-25 $(70,6 \%)$, kolejna duża grupa składała się z badanych poniżej 18 roku życia $(16,8 \%)$, $8.8 \%$ stanowili respondenci $\mathrm{w}$ wieku $41-60$ lat, a pozostali uczestnicy badania byli z przedziału wiekowego $41-60$ lat $(2,5 \%)$ oraz powyżej lat 60 (1,3\%). Najwięcej ankietowanych zamieszkiwało wieś $(47,5 \%)$. Przeważająca liczba ankietowanych posiadała wykształcenie średnie $(57,1 \%)$. Duży odsetek stanowiły również osoby z wykształceniem wyższym $(23,1 \%)$.

W merytorycznej części ankiety zapytano respondentów o ocenę swojej świadomości ekologicznej. Uzyskane wyniki zestawiono na wykresie nr 1. 


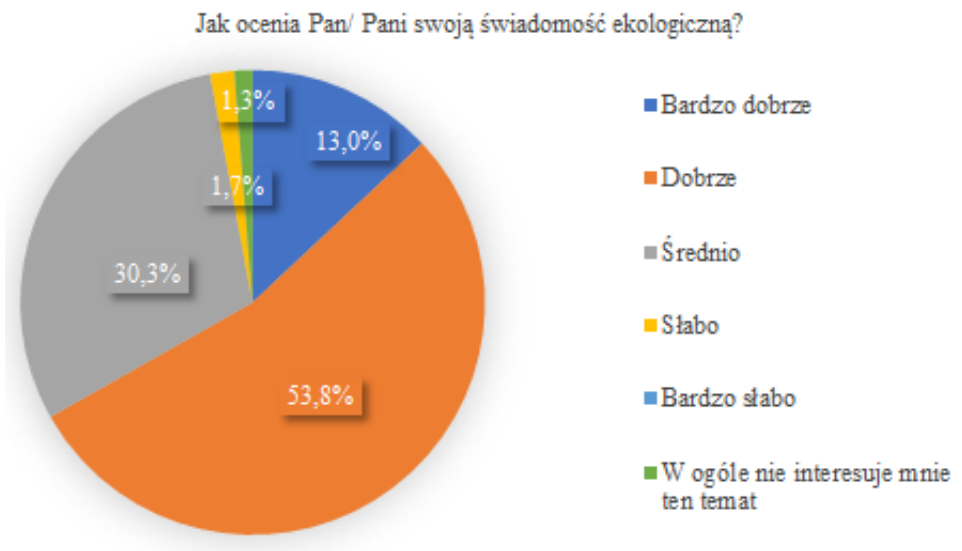

Wykres 1. Struktura odpowiedzi respondentów na pytanie: ,Jak ocenia Pan/Pani swoją świadomość ekologiczną?"

Źródło: opracowanie własne

Jak wynika z danych zestawionych na wykresie 1 większość mieszkańców Lubelszczyzny $(53,8 \%)$ oceniła swoją świadomość ekologiczną jako dobrą. Kolejne 30,3\% ankietowanych określiło swoją świadomość w stopniu średnim. Jedynie 13\% respondentów wybrało odpowiedź „bardzo dobrze”. Świadczy to, że samoocena świadomości ekologicznej społeczeństwa jest na zadowalającym poziomie, ponieważ dość mały procent ocenia swoją świadomość w stopniu słabym. Dodać należy, iż jedynie 1,3\% w ogóle nie interesowało się tą tematyką. Takie wyniki mogą być spowodowane tym, że w badaniach wzięło udział wielu młodych ludzi, którzy są wychowywani w duchu dbałości o środowisko.

Następnie poproszono ankietowanych o zidentyfikowanie głównych powodów, dla których - według nich - warto dbać o środowisko (wykres 2).

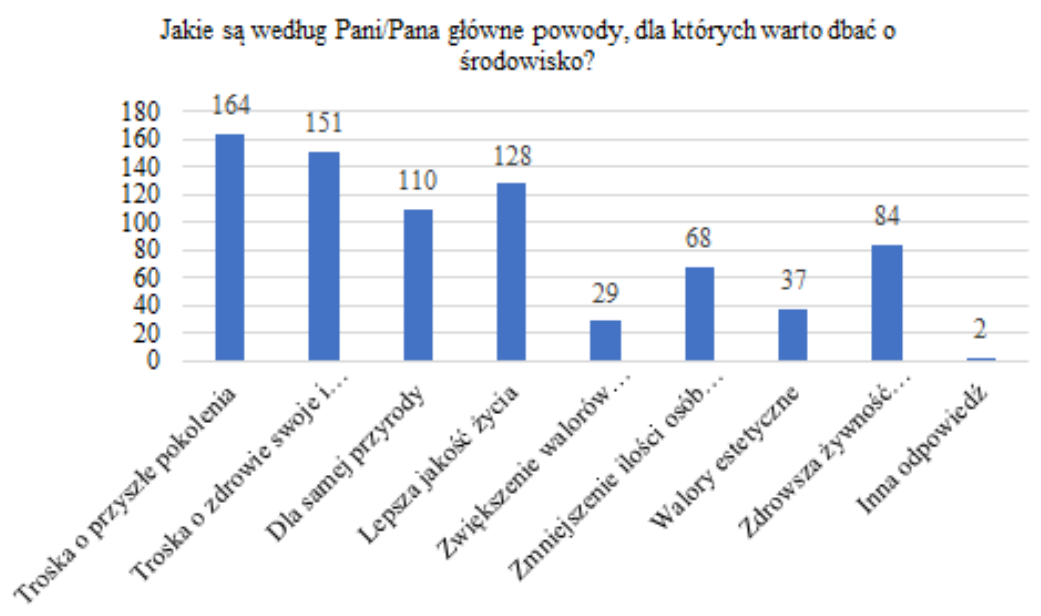

Wykres 2. Struktura odpowiedzi respondentów na pytanie: „Jakie są według Pani/Pana główne powody, dla których warto dbać o środowisko" Źródło: opracowanie własne 
W tym pytaniu ankietowani mieli możliwość wyboru 3 odpowiedzi. Najczęściej deklarowaną przez respondentów odpowiedzią była „troska o przyszłe pokolenie” (164 osoby). 151 osób wybrało „troskę o zdrowie swoje i najbliższych”. Dużo wskazań odnotowano również w odniesieniu do odpowiedzi „lepsza jakość życia” (128 badanych). Świadczyć to może o dbałości społeczeństwa o przyszłość swoich najbliższych. Mieszkańcy Lubeszczyzny dążą do tego, aby następne pokolenia mogły cieszyć się naturą, żywotnością Ziemi w lepszym stopniu niż obecnie.

Kolejnymi powodami, dla których warto dbać o środowisko, to według ankietowanych przede wszystkim ochrona flory i fauny oraz dbanie o ekosystem. 110 osób wskazało bowiem odpowiedź „dla samej przyrody”, a kolejne 84 opowiedziało się za zdrowszą żywnością pochodzącą z czystszych terenów. Niektórzy ankietowani za słuszny powód uważali ponadto zwiększanie walorów turystycznych i estetycznych. Następną przyczyną skłaniającą do dbania o środowisko była obawa społeczeństwa przed chorobami cywilizacyjnymi.

Ankietowani mieli również możliwość dodania własnej odpowiedzi i były nimi: uniknięcie katastrofy ekologicznej, zbyt duże zaśmiecenie Ziemi oraz brak świadomości, co się dzieje.

W kolejnym pytaniu zapytano ankietowanych o to, czym objawia się ich świadomość ekologiczna. Uzyskane odpowiedzi zaprezentowano na wykresie 3.

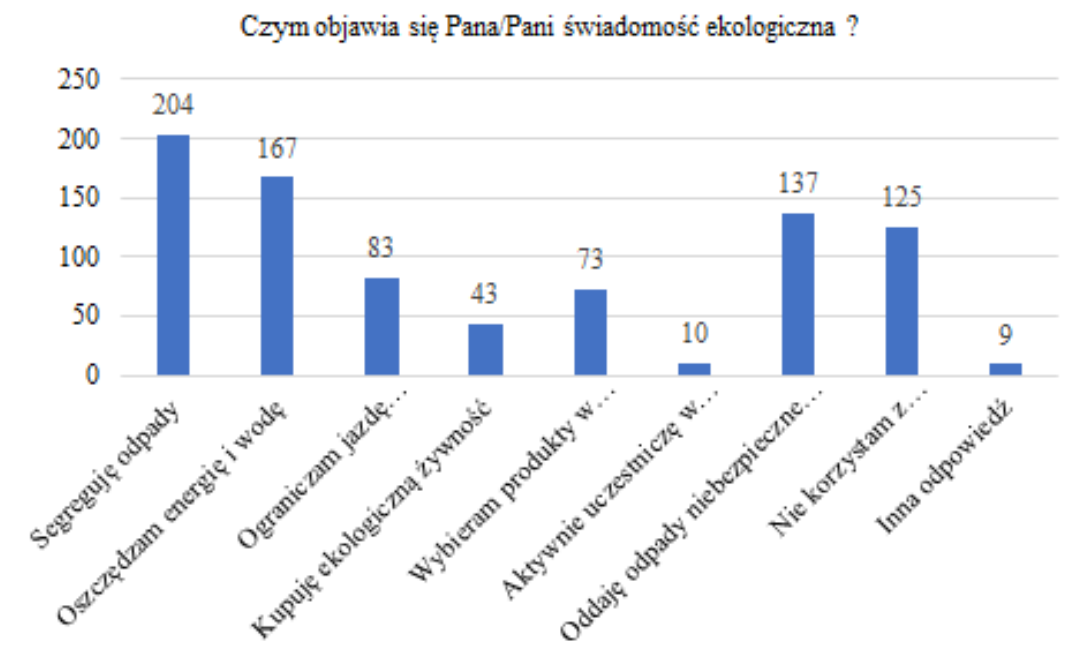

Wykres 3. Struktura odpowiedzi respondentów na pytanie: „Czym objawia się Pana/Pani świadomość ekologiczna?"

Źródło: opracowanie własne

Odpowiadając na pytanie „Czym objawia się Pana/Pani świadomość ekologiczna?", 204 ankietowanych opowiedziało się za segregacją odpadów. U 167 osób świadomość ekologiczna objawia się poprzez oszczędzanie wody i energii. Prawie na takim samym poziomie znajdują się odpowiedzi: „oddaję odpady niebezpieczne” oraz „nie korzystam z jednorazowych siatek", kolejno 137 i 125 osób. Innymi działaniami wybranymi przez mieszkańców Lubelszczyzny były: jazda środkami transportu miejskiego 
oraz wybór produktów w ekologicznych opakowaniach czy kupno ekologicznych produktów ogólnie. Jedynie 10 badanych opowiedziało się za udziałem w akcjach ekologicznych.

Również w tym pytaniu ankietowani mieli możliwość dodania własnych odpowiedzi; były to odpowiedzi pojedyncze, takie jak: wegetarianizm, ograniczanie wykorzystania plastikowych produktów, uprawa surowców ekologicznych, używanie butelek filtrujących wodę i metalowych słomek, korzystanie z energii odnawialnej.

Następnie poproszono osoby biorące udział w badaniu o wypowiedzenie się na temat konieczności obowiązywania w szkołach edukacji ekologicznej (wykres 4).

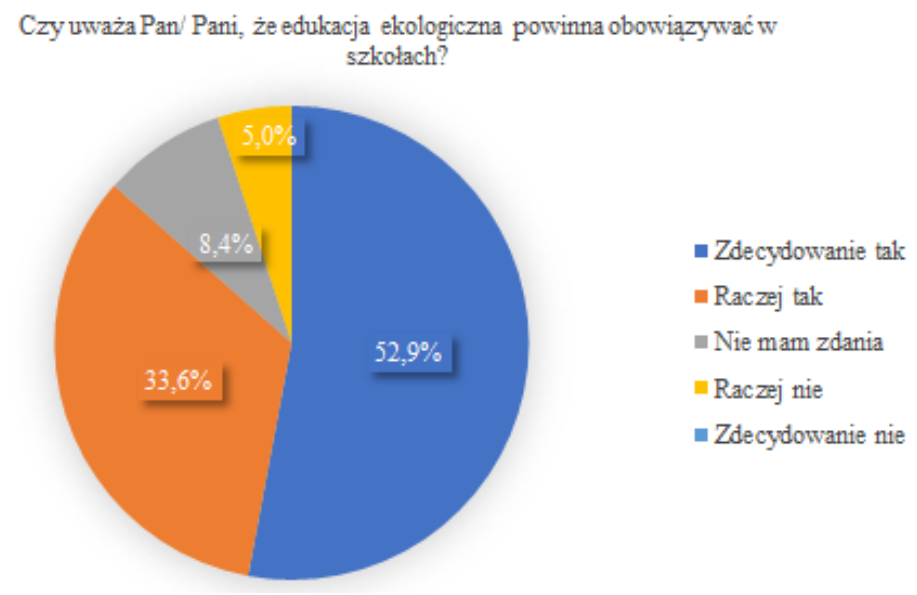

Wykres 4. Struktura odpowiedzi respondentów na pytanie: „Czy uważa Pan/Pani, że edukacja ekologiczna powinna obowiązywać w szkołach?”

Zródło: opracowanie własne

Ponad połowa $(52,9 \%)$ ankietowanych zdecydowanie uważała, że edukacja ekologiczna powinna być prowadzona w szkole. Kolorem pomarańczowym na wykresie oznaczono odpowiedz „raczej tak” (33,6\%). Oznacza to, że mieszkańcy Lubelszczyzny są zwolennikami wprowadzenia edukacji ekologicznej do placówek oświaty. Świadczyć to może o tym, że społeczeństwo widzi potrzebę, a nawet konieczność kształcenia dzieci od najmłodszych lat $\mathrm{w}$ trosce o środowisko. Może być to jedną $\mathrm{z}$ wielu metod zaszczepiania w społeczeństwie chęci dbania o środowisko przez całe życie. $8,4 \%$ badanych nie miało zdania w tym temacie. A tylko 5\% wybrało odpowiedź „raczej nie”. Tak mały odsetek odpowiedzi świadczy o niewielkiej ilości osób nie do końca przekonanych o słuszności tej tezy.

Ankietowanych zapytano również o znajomość oznakowania produktów ekologicznych. Zebrane w badaniach dane przedstawiono na wykresie 5 .

Analizując uzyskane na to pytanie odpowiedzi można zaobserwować, że 71,8\% osób biorących udział w badaniu uważało swoją znajomość owych znaków za dość sporą, choć przyznali się do niewielkich braków wiedzy. Tylko $10,1 \%$ była zdecydowanie pewna swojej znajomości oznakowania produktów ekologicznych. Zauważyć tu więc można bardzo pozytywne zjawisko świadczące o dużej wiedzy w kwestii ekoproduktów. Ludzie, znając oznakowania, wybierają bowiem produkty z większą świadomością. 
Dodać należy, iż 15,5\% respondentów opowiadało się za odpowiedzią „raczej nie”, a jedyne 2,5\% ,zdecydowanie nie”, ponieważ nie interesuje ich ta tematyka. Jest to więc kolejne pytanie, w którym odpowiedzi przeczące stanowią niewielki procent, co świadczy o dużej świadomości społeczeństwa.

Kolejne pytanie sprawdzające wiedzę na temat środowiska dotyczyło znajomości różnicy między rolnictwem ekologicznym a konwencjonalnym (wykres 6).

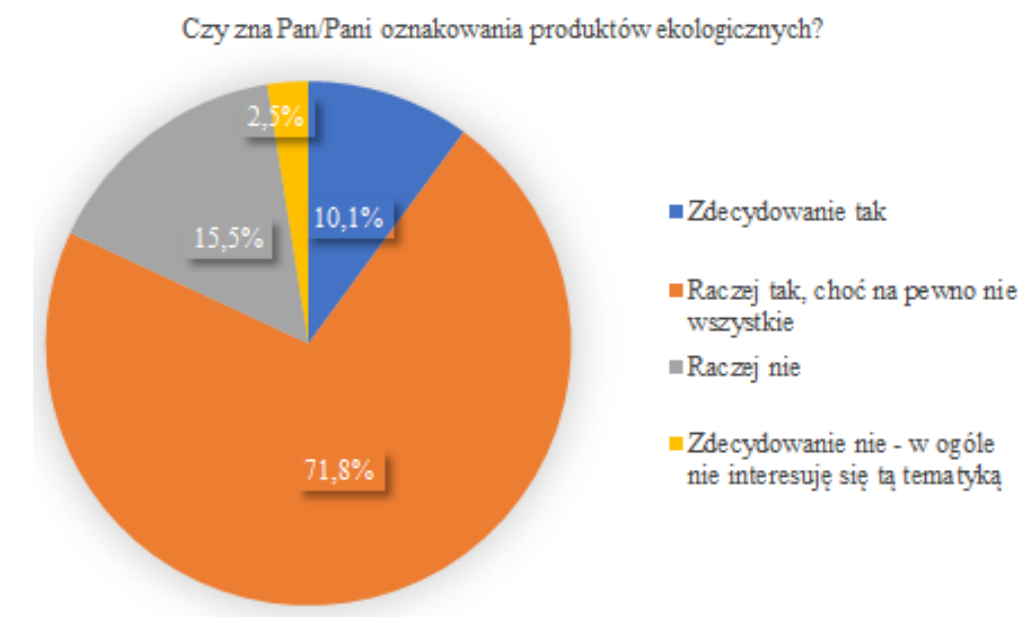

Wykres 5. Struktura odpowiedzi respondentów na pytanie: „Czy zna Pan/Pani oznakowania produktów ekologicznych?"

Źródło: opracowanie własne

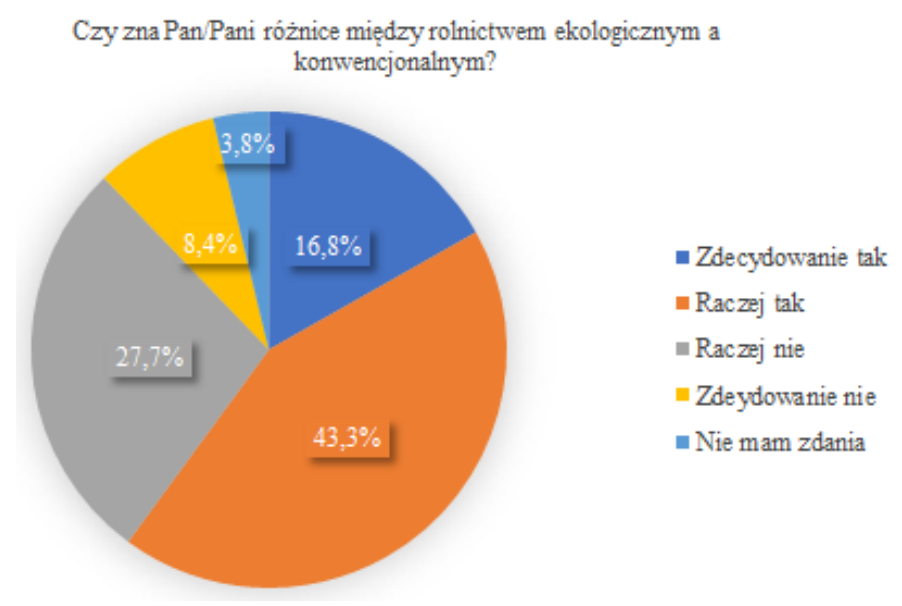

Wykres 6. Struktura odpowiedzi respondentów na pytanie: „Czy zna Pan/Pani różnice między rolnictwem ekologicznym a konwencjonalnym?"

Źródło: opracowanie własne 
Analizując strukturę odpowiedzi na to pytanie, można zauważyć, że występuje duże zróżnicowanie odpowiedzi. Jednakże przeważającą odpowiedzią $(43,3 \%)$ była odpowiedz „raczej tak”; kolejne 16,8\% odpowiedziało „zdecydowanie tak”, co daje łącznie około $60 \%$ respondentów. Świadczy to o znajomości tych pojęć i różnicy między nimi.

Z kolei kolorem szarym oznaczono odpowiedz ,raczej nie” i wybrało ją 27,7\% ankietowanych, kolejno 8,4\% ,zdecydowanie nie”. Pozostali ankietowani wybrali odpowiedź „nie mam zdania”. Wynikać z tego może, że wciąż dużo osób nie zna różnic między rolnictwem ekologicznym a konwencjonalnym.

Jednym z celów realizowanej ankiety badawczej było również poznanie opinii respondentów na temat czynników bądź zjawisk mających największy wpływ na poprawę stanu środowiska w naszym kraju - wykres 7.

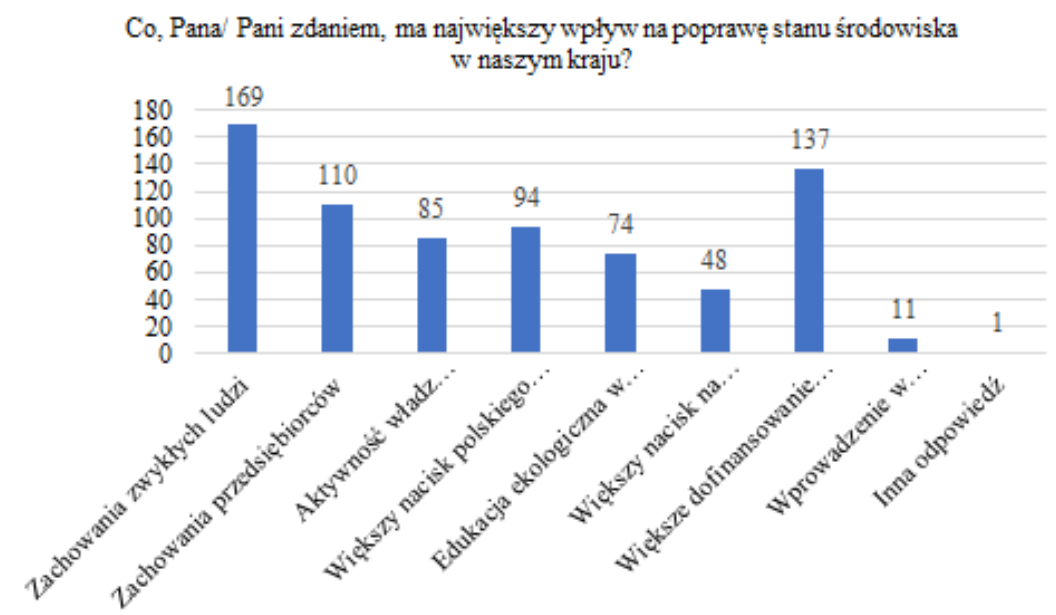

Wykres 7. Struktura odpowiedzi respondentów na pytanie: „Co, Pana/Pani zdaniem, ma największy wpływ na poprawę stanu środowiska w naszym kraju?” Źródło: opracowanie własne

W tym pytaniu ponownie ankietowani mieli możliwość zaznaczenia 3 odpowiedzi. Najwięcej osób (169) uważało, że największy wpływ na poprawę stanu środowiska w naszym kraju mają zachowania zwykłych ludzi. Jednak 110 osób również wybrało zachowania przedsiębiorców. Wydaje się więc, że zarówno jedno, jak i drugie ma ogromny wpływ na nasz świat. Kolejną przyczyną są dofinansowania na działania proekologiczne, takie jak wymiana starych pieców na nowe, czy fotowoltaika. Część osób uważa także działalność władz rządowych (94) oraz władz lokalnych (85) za ważny czynnik poprawiający stan środowiska w Polsce. Ich aktywność w różnego rodzaju projekty, zachęca bowiem innych. 74 ankietowanych opowiedziało się za edukacją ekologiczną w szkołach, a kolejne 48 osób za większym naciskiem na edukację ekologiczną również w social mediach. 11 badanych wybrało ponadto odpowiedź ,wprowadzenie w miastach stref ograniczonego ruchu".

W tym pytaniu ponownie była także możliwość dodania własnych odpowiedzi; zdecydowała się na to tylko jedna osoba i wpisała: WWF. Jest to organizacja pozarządowa „World Wide Fund for Nature”. 
Następnie zapytano osoby biorące udział w badaniu o to, co, ich zdaniem, ma największy wpływ na pogorszenie stanu środowiska w naszym kraju. Zebrane informacje zaprezentowano na wykresie 8 .

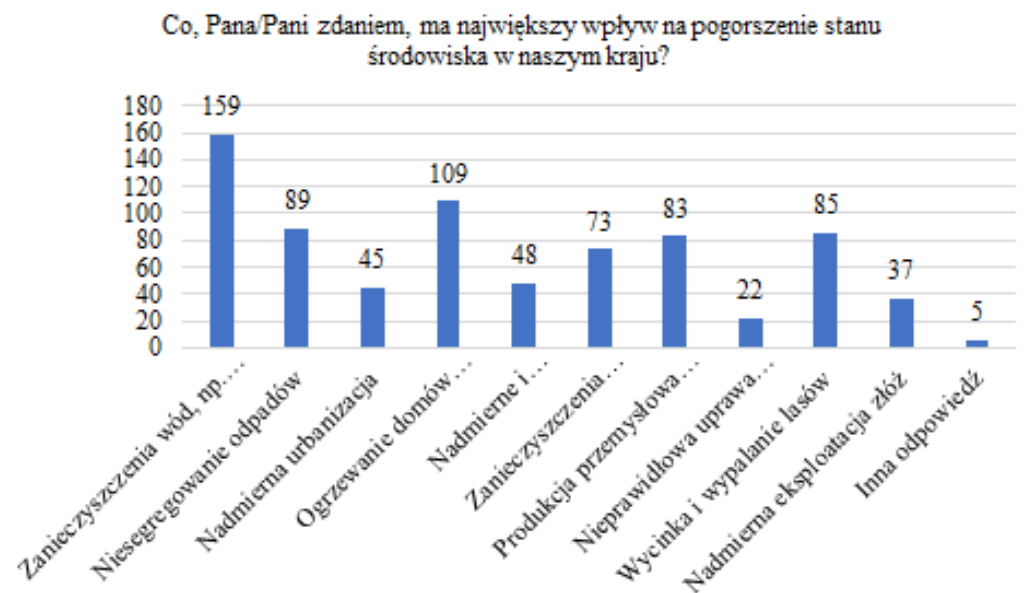

Wykres 8. Struktura odpowiedzi respondentów na pytanie: „Co, Pana/Pani zdaniem, ma największy wpływ na pogorszenie stanu środowiska w naszym kraju?"

Źródło: opracowanie własne

Jako główną przyczynę pogorszenia stanu środowiska w naszym kraju ankietowani wskazali zanieczyszczenie wód. Kolejnym największym wynikiem jest ogrzewanie domów piecami starej generacji. Powszechnie wiadomo, że takie piece są niebezpieczne dla przyrody. Jednak to zjawisko jest wciąż zwalczane, w tym celu stosowane są dofinansowania do wymiany pieców na ekologiczne.

Kolejną przyczyną jest według respondentów niesegregowanie odpadów. Jednakże coraz większe koszty wywozu niesegregowanych śmieci skłaniają społeczeństwo do zaniechania tego procederu. Prowadzona $\mathrm{w}$ ten sposób polityka państwa sprawia, że segregacja śmieci jest bardziej opłacalna dla konsumenta [Karpus 2011].

85 osób wybrało wycinkę i wypalanie lasów jako czynnik pogarszający stan środowiska. Podobny wynik, bo 83, uzyskała odpowiedź wskazująca na produkcję przemysłową niekorzystającą z rozwiązań zmniejszających ich wpływ na degradacje środowiska. Istnieje wiele możliwości zniwelowania powyższego zjawiska i należy z nich korzystać. Dla przedsiębiorstwa wiąże się to z dość wysokim kosztem, ale korzyści dla otoczenia będą bezcenne.

Ankietowani wybrali również odpowiedzi „zanieczyszczenia transportowe” oraz „nadmierna urbanizacja”, które się ze sobą łączą. Rozwiązaniem tego problemu może być stopniowa zamiana transportu samochodowego na transport publiczny.

48 respondentów uznało także niewłaściwe użycie nawozów sztucznych jako czynnik wpływający na pogorszenie stanu środowiska. Mniejszą popularnością cieszyły się natomiast odpowiedzi „nadmierna eksploatacja złóż” oraz „nieprawidłowa uprawa roli i/lub zbyt intensywny wypas bydła". 


\section{Podsumowanie}

Z przeprowadzonych badań można wysnuć następujący wniosek, który ma pozytywny wydźwięk - świadomość ekologiczna mieszkańców Lubelszczyzny plasuje się na dość wysokim poziomie. Większość badanych osób wykazuje bowiem zainteresowanie tematyką ekologii, rozróżnia rolnictwo ekologiczne od konwencjonalnego oraz deklaruje znajomość oznakowania produktów ekologicznych. Zdecydowana większość respondentów opowiada się ponadto za potrzebą wprowadzenia edukacji ekologicznej w szkołach. Uważają to rozwiązanie za słuszne i potrzebne. Ankietowani wyróżniają się intuicyjną świadomością ekologiczną, potrafią wskazać problemy, które zagrażają środowisku w tym regionie.

Reasumując, ocena świadomości ekologicznej społeczności Lubelszczyzny jest zadowalająca. Po przeanalizowaniu uzyskanych wyników w zrealizowanym badaniu można bowiem stwierdzić, że ludzie są świadomi tematyki ekologii oraz otaczających ich zagrożeń dla środowiska.

\section{Bibliografia}

Domagalska J., Buczkowska M., 2015. Rolnictwo ekologiczne - szanse i perspektywy rozwoju, Probl. Hig. Epidemiol. 96(2), 370-376.

Dubas A., 2007. Zrównoważony rozwój we współczesnych systemach rolnictwa, Fragm. Agron. (XXIV), 3(95), Poznań, 72-73.

Ducka M., 2011. Ekologiczne rolnictwo i ogrodnictwo, Krajowe Centrum Edukacji Roln. w Brwinowie, Falenty.

Dz.U. $2001 \mathrm{nr} 62$ poz. 627 Ustawa z dnia 27 kwietnia 2001 r. Prawo ochrony środowiska.

Dz.U. 2009 Nr 116 poz. 975 Ustawa z dnia 25 czerwca 2009 r. o rolnictwie ekologicznym.

Dz.U. L 155 z 12.6.2019 Dyrektywa Parlamentu Europejskiego i Rady (UE) 2019/904 z dnia 5 czerwca 2019 r. w sprawie zmniejszenia wpływu niektórych produktów z tworzyw sztucznych na środowisko.

Gruszecki K., 2011. Prawo Ochrony Środowiska: Komentarz, 3 wyd., Warszawa, 36-44.

Iwanicki W., 2017. Żywność konwencjonalna a żywność ekologiczna, http://www.ekolubelszczyzna.pl/zywnosc/zywnosc-konwencjonalna [data dostępu: 26.03.2021].

Karpus K., 2011. Gospodarowanie odpadami w świetle orzecznictwa Trybunału Sprawiedliwości Unii Europejskiej na gruncie dyrektyw ramowych w sprawie odpadów, Wydawnictwo państwowej wyższej szkoły zawodowej we Włocławku, Włocłwek, 285-286.

Kostecka J., Mroczek J.R., 2007. Świadomość ekologiczna rolników a zrównoważony rozwój obszarów wiejskich podkarpacia, Ekonomia i Środowisko 2(32), 165-177.

Różnice między rolnictwem ekologicznym a konwencjonalnym, https://zycierolnika.pl/index.php/aktualnosci/item/3186-roznice-miedzy-rolnictwem-ekologicznym-a-konwencjonalnym [data dostępu: 25.03.2021].

Runowski H., 2009. Rolnictwo ekologiczne - rozwój czy regres?, Rocz. Nauk Roln., seria G, 96, 4, Warszawa, 183-185.

Sobczyk W., 2003. Edukacja ekologiczna i prozdrowotna, Wyd. Nauk. Akad. Pedagog. Kraków.

Szpunar M., 2014. Nowa Ekologia Mediów, Studia Humanist. AHG, 13, 1.

Tekiela A., Dudzik S., Kawka I., 2020. Gospodarowanie odpadami tworzyw sztucznych w obiegu zamkniętym w prawie Unii Europejskiej, Kraków.

Tuszyńska L., 2013. Świadomość ekologiczna społeczności lokalnych. Oczekiwania a rzeczywistość, Rocznik Świętokrzyski. Ser. B - Nauki Przyr. 34, 149-160, Kraków, 151-153.

Tyburski J., Żakowska-Biemans S., 2007. Wprowadzenie do rolnictwa ekologicznego. Wyd. SGGW, Warszawa, 191-195. 
WWF, 2020. Plastik not fantastic, https://www.wwf.pl/aktualnosci/plastik-not-fantastic [data dostępu: 24.03.2021].

Zawada Ł., 2016. Owoce i warzywa z uprawy ekologicznej i konwencjonalnej - czym się różnią?, http://ogrodnictwo.expert/warzywnictwo/owoce-i-warzywa-z-uprawy-ekologicznej-i-konwencjonalnej-czym-sie-roznia/ [data dostępu: 25.03.2021].

Żelezik M., 2009. Dlaczego rolnictwo ekologiczne?, Rocznik Świętokrzyski. Ser. B - Nauki Przyr. 30, Kielce, 155-166. 


$$
\begin{gathered}
\text { Katarzyna Karpińska }{ }^{1,2}, \text { Damian Jaguszewski }{ }^{1}, \text { Gabriela Kosowska }^{1}, \\
\text { Bożena Nowakowicz-Dębek }{ }^{1}
\end{gathered}
$$

\section{Zagrożenie halasem w środowisku pracy operatora ladowarki czołowej}

Noise pollution in the working environment of the front-end loader operator

Zapotrzebowanie na maszyny budowlane i wykwalifikowanych operatorów tego rodzaju sprzętu w ostatnich latach znacznie wzrosło. Fakt ten jest konsekwencją dynamicznego rozwoju branży budowlanej w naszym kraju. Wykorzystywanie takiego sprzętu nieodłącznie jest związane $\mathrm{z}$ występowaniem wielu niebezpieczeństw, które w mniejszym lub większym stopniu zagrażają pracownikom. Jednym z nich jest hałas, który uznawany jest za czynnik szkodliwy. Długotrwała praca w narażeniu na ten czynnik może się wiązać z poważnymi konsekwencjami [Rabinowitz 2000]. Polskie prawo nakazuje zapewniać bezpieczne i higieniczne środowiska pracy. Dlatego jednym z obowiązków pracodawcy jest ochrona pracowników. Podstawową ochrony operatorów ładowarek jest niwelowanie lub ograniczanie występującego w ich pracy hałasu [Dz. U. 2005, nr 157, poz. 1318]. Pomocne w ochronie przed hałasem są badania natężenia tego czynnika. Odpowiednie dobranie ochron pozwala uniknąć problemów wynikających ze stosowania zbyt mocnej lub niewystarczającej ochrony [Młyński i Kozłowski 2016].

\section{Halas}

Za hałas uznaje się wszystkie dźwięki wywierające negatywny wpływ na organizm człowieka. Hałas jest czynnikiem fizycznym, który w środowisku pracy jest kwalifikowany jako czynnik uciążliwy, ponieważ może powodować obniżenie wydajności pracownika. Jest on także czynnikiem szkodliwym, gdyż długotrwała influencja może doprowadzić do pogorszenia stanu zdrowia pracownika [Dyrektywa 2002/49/WE]. Emisja hałasu z otoczenia jest niemal ciągła. Wszystkie urządzenia, maszyny, a nawet człowiek może być źródłem powstania hałasu. Emitowany jest on przez samochody jeżdżące po drogach, maszyny w zakładach przemysłowych, a także przez sprzęty wykorzystywane na budowach [Gardziejczyk 2010].

Człowiek dostosowany jest do rejestrowania dźwięków z przedziału częstotliwości 20-20 $000 \mathrm{~Hz}$. Dźwięki występujące w otoczeniu człowieka, a będące poza tym zakresem, są niesłyszalne. Przyjmując za kryterium podziału hałasu zakres częstotliwości, możemy podzielić go na infradźwiękowy, słyszalny i ultradźwiękowy [Boroń i in. 2013].

Siłę dźwięku mierzy się logarytmiczną jednostką miary, jaką jest decybel [dB]. Najmniejszy poziom ciśnienia akustycznego tonu o określonej częstotliwości wywołującego wrażenie słuchowe u osoby odbierającej jest nazywany progiem słyszalności.

\footnotetext{
${ }^{1}$ Uniwersytet Przyrodniczy w Lublinie, Wydział Nauk o Zwierzętach i Biogospodarki

${ }^{2}$ katarzyna1297@gmail.com
} 
Górna bariera słyszalności jest krzywą przedstawiającą próg słyszenia bolesnego, czyli minimalny poziom ciśnienia akustycznego tonu o określonej częstotliwości, powodującego u konkretnego odbiorcy wrażenie bólu [Ekert i in. 2018]. Progi te u człowieka z prawidłowym słuchem określone zostały na poziomach [Mizierski i in. 2004]:

- próg słyszalności: $0 \mathrm{~dB} \mathrm{HL}$,

- próg bólu: 110-140 dB HL,

- uszkodzenie słuchu: $>140 \mathrm{~dB}$ HL.

\section{Wplyw hałasu na organizm czlowieka}

Kontakt z hałasem może być niegroźny w skutkach, jednakże długotrwałe przebywanie $\mathrm{w}$ środowisku o podwyższonym poziomie hałasu może prowadzić do poważnych problemów zdrowotnych.

Główną dolegliwością osób pracujących w narażeniu na hałas jest osłabienie słuchu. Zdarza się, że długotrwałe narażenie na ten czynnik doprowadza do całkowitej utraty słuchu. Utrata słuchu wywołana hałasem to zmysłowo-nerwowy ubytek słuchu, który zaczyna się przy wyższych częstotliwościach $(3000$ do $6000 \mathrm{~Hz})$ i rozwija się stopniowo w wyniku chronicznego narażenia na nadmierne poziomy dźwięku [Rabinowitz 2000].

Dźwięki z otoczenia są bodźcami, które nieustannie wpływają na układ nerwowy człowieka. Nerwy pobudzane przez dźwięki przyczyniają się do zmian stanu psychicznego. Miejsca wypełnione hałasem, jak i te, które na pozór wydają się ciche, mogą przyczyniać się do powstania uczucia zmęczenia, ospałości, zdenerwowania oraz osłabienia uwagi. Wielu ludzi cierpi na problemy emocjonalne i nerwowe spowodowane przez hałas. Częstym objawem zbyt dużego obciążenia układu nerwowego są problemy ze snem. Podczas snu organizm powinien zregenerować siły, a w momencie, gdy nie może tego zrobić, dąży do skrajnego wyczerpania [Leśnikowska-Matusiak i Wnuk 2014].

\section{Praca w narażeniu na hałas}

Wykonywanie pracy w obszarach, gdzie występuje nadmierna emisja hałasu, jest znacznie utrudnione. Opóźnione reakcje oraz brak skupienia znacznie destabilizują wykonywanie prac wymagających szczególnego skupienia i dokładności [Woźny i in. 2014]. Praca w warunkach ciągłego hałasu może doprowadzić do utworzenia się bariery, która zaburzy komunikacje między pracownikami. Utrudniona wymiana informacji generuje niepotrzebne nerwy oraz wzmaga ryzyko powstawania wypadków [Woźniak 2015].

Przez wzgląd na szkodliwy charakter hałasu i jego powszechne występowanie został on sklasyfikowany jako czynnik mogący spowodować uszczerbek na zdrowiu, a w konsekwencji chorobę zawodową [Dz. U. 2013, poz. 1367]. Według najnowszego opracowania, w roku 2019 odnotowano 2065 przypadków chorób zawodowych, w tym 75 przypadków dotyczyło obustronnego trwałego uszczerbku słuchu. Stwierdzone przypadki ubytku słuchu stanowiły około 4\% wszystkich przypadków chorób zawodowych w Polsce w tym roku [Świątkowska i in. 2020]. 


\section{Kryteria oceny hałasu}

Każde stanowisko pracy jest w innym stopniu narażone na hałas. Stopień ten jest zależny od wielu składowych tworzący środowisko pracy, m.in.: wielkość pomieszczeń pracy, używane narzędzia, rodzaj wykorzystywanej wentylacji. Chcąc zapewnić pracownikom bezpieczne i przyjazne warunki pracy, należy wykonywać regularne pomiary czynników szkodliwych [Dz.U. $2011 \mathrm{nr} 33$ poz. 166].

Tabela 1. Wartości progów działania dla wielkości charakteryzujących hałas w środowisku pracy dla ogółu pracowników [Dz.U. $2005 \mathrm{nr} 157$ poz. 1318, Dz.U. 2018 poz. 1286]

\begin{tabular}{|l|c|}
\hline \multicolumn{1}{|c|}{ Wielkość charakteryzująca hałas } & $\begin{array}{c}\text { Dopuszczalny } \\
\text { poziom hałasu }\end{array}$ \\
\hline $\begin{array}{l}\text { Poziom ekspozycji na hałas odniesiony do 8-godzinnego dobowego } \\
\text { lub tygodniowego wymiaru czasu pracy - wartość progu działania }\end{array}$ & $80 \mathrm{~dB}$ \\
\hline $\begin{array}{l}\text { Poziom ekspozycji na hałas odniesiony do 8-godzinnego dobowego } \\
\text { wymiaru czasu pracy - NDN }\end{array}$ & $85 \mathrm{~dB}$ \\
\hline Maksymalny poziom dźwięku A & $115 \mathrm{~dB}$ \\
\hline Szczytowy poziom dźwięku C & $135 \mathrm{~dB}$ \\
\hline
\end{tabular}

Wyniki przeprowadzanych pomiarów powinny odzwierciedlać realną sytuację na badanym stanowisku. W analizie pomocne jest odniesienie otrzymanych wartości do wielkości normatywnych, które zamieszczono w tabeli 1.

\section{Metody ochrony przed halasem}

Kontrolowanie zjawiska hałasu za pomocą sprzętu ochronnego oraz przez dokonywanie zmian oprzyrządowania może zmniejszyć szkodliwy wpływ hałasu na pracowników. Najlepszym rozwiązaniem niwelującym hałas byłoby jego całkowite usunięcie ze środowiska pracy. Niestety prawie niemożliwe jest zredukowanie hałasu do zera. Dlatego koniecznym jest dążenie do jego minimalizacji przy równoczesnym wykorzystaniu środków ochronnych [Pleban 2019].

Ochrony stosowane w zakładach pracy dobierane są w zależności od stopnia narażenia pracowników na dany czynnik. Pracodawcy mogą przebierać w środkach dostarczanych przez producentów sprzętu ochronnego. Ze względu na zasięg działania ochron można podzielić je na zbiorowe oraz indywidualne.

Zbiorowe środki ochronne projektowane są do ochrony grup pracowników wykonujących swoje zadania $\mathrm{w}$ obrębie tego samego środowiska pracy przed zagrożeniami i działaniem czynników szkodliwych. Są one rozwiązaniami technicznymi wykorzystywanymi w przestrzeniach zamkniętych, urządzeniach roboczych i innych elementach procesów technologicznych [Dz.U. 2003 nr 169 poz. 1650]. Ochrony zbiorowe zazwyczaj są pierwszym rodzajem ochron, po które sięgają pracodawcy.

Indywidualne środki ochronne to wszelki sprzęt, którego pracownik może używać, aby chronić swój organizm przed negatywnymi skutkami czynników szkodliwych. Do grupy tej należy także każde wyposażenie dodatkowe używane w celu zmniejszania narażenia na dany czynnik [Dyrektywa 89/656/EWG]. Indywidualne środki ochronne 
wykorzystuje się w przypadkach, w których ochrony zbiorowe nie zapewniają odpowiedniego bezpieczeństwa lub gdy ich stosowanie byłoby utrudnione. Ochrony indywidualne są elastyczniejsze pod względem dobrania parametrów indywidualnie do każdego pracownika, zależnie od potrzeb.

Prawidłowo przeprowadzony dobór ochron zapewnia pracownikowi komfortową i bezpieczną pracę, bez obaw o późniejsze konsekwencje pracy w szkodliwym środowisku. Dobieranie właściwych środków ochrony dla danego stanowiska powinno opierać się na wynikach z wcześniej przeprowadzonych pomiarów [Młyński i Kozłowski 2016].

\section{Cel pracy}

Pracownik obsługujący w trakcie pracy maszyny lub urządzenia narażony jest na wiele zagrożeń, w tym również na hałas. Dlatego celem badań była ocena narażenia na hałas operatora ładowarki czołowej.

\section{Materiał i metody badań}

Przeprowadzone badania dotyczyły stanowiska operatora ładowarki wykonującego swą pracę w firmie działającej w południowo-wschodniej części kraju. Do czynności operatora należy załadunek kamieni o różnej średnicy na podjeżdżające samochody. W zależności od sezonu operator nasypuje średnio 60 samochodów dziennie. Największe nasilenie prac jest w okresie wiosennym i letnim. Operator w swojej pracy wykorzystuje ładowarkę JCB 426e, który jest jednym z lepiej wyposażonych modeli tego producenta. Według instrukcji tej maszyny, jej wyposażenie powinno zapewniać operatorom bezpieczną i komfortową pracę.

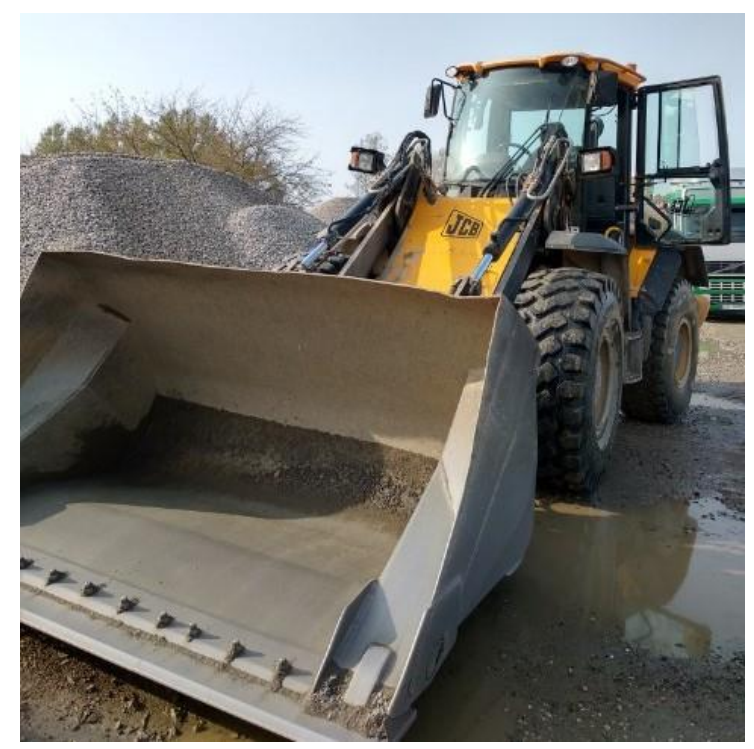

Ryc. 1. Ładowarka JCB 426e (fot. własna) 
Pomiary hałasu zostały wykonane sonometrem Sonopan DSA-50, klasa 1. Zastosowana została osłona meteo, która zniwelowała wpływ ruchu powietrza na odczyty miernika. Przed wykonaniem pomiarów sprzęt został skalibrowany.

Wykonane pomiary oparte były na normie PN-EN 01307:1994. Pozwoliło to na określenie narażenia operatora ładowarki na hałas $\mathrm{w}$ trakcie rutynowych czynności wykonywanych w pracy. Badania zostały przeprowadzone w kabinie ładowarki w trakcie typowego dnia pracy. Pomiary zostały przeprowadzone w taki w sposób, aby jak najlepiej odzwierciedlały wpływ hałasu na pracownika. W tym celu mikrofon sonometru został umieszczony w pobliżu ucha operatora. Pomiary hałasu wykonano na stanowisku pracy, w trakcie pracy maszyny. Pomiary przeprowadzano w warunkach, jakie na co dzień występują na tym stanowisku pracy.

Wszystkie otwory okienne oraz dachowe w trakcie prowadzenia pomiarów były zamknięte, a układ wentylacji włączony. W celu określenia dziennej ekspozycji operatora na hałas w ładowarce uwzględniono również wielkość niepewności rozszerzonej.

Wykonanie pomiarów polegało na zmierzeniu wartości natężenia hałasu przy codziennych czynnościach wykonywanych przez operatora tj.: nabieranie kruszywa, nabieranie kamienia, sypanie kruszywa na przyczepę i całą czynność dla kruszywa. Pomiary zostały wykonane trzykrotnie dla każdej czynności. Dzięki temu otrzymane wyniki dobrze obrazują dzienny poziom narażenia pracownika.

Do wykonania obliczeń wykorzystano poniższe wzory:

- poziom ekspozycji na hałas odniesiony do 8-godzinnego dnia pracy

$$
L_{E X, 8 h}=L_{A e q, T e}+10 \log \left(\frac{T e}{T o}\right)[d B]
$$

gdzie:

$\mathrm{L}_{\mathrm{EX}, 8 \mathrm{~h}}$ - poziom ekspozycji na hałas odniesiony do 8-godzinnego dnia pracy,

$\mathrm{L}_{\mathrm{Aeq}, \mathrm{Te}}$ - równoważny poziom dźwięku A efektywnej długości dnia pracy, w $\mathrm{dB}$,

$\mathrm{Te}$ - czas ekspozycji na hałas, w min,

To - przedział czasowy odniesienia;

- równoważny poziom dźwięku

$$
L_{A e q, T e}=10 \log \left(\frac{1}{N} \sum_{n=1}^{N} 10^{0,1 L_{A e q, T e, n}}\right)
$$

gdzie:

$\mathrm{L}_{\mathrm{Aeq}, \mathrm{Te}}$ - równoważny poziom dźwięku A n-tego pomiaru (próbki), w $\mathrm{dB}$,

$\mathrm{n}$ - liczba pomiarów;

- szacowanie niepewności

$$
U=k * u\left(L_{E X, 8 h}\right)=1,65 * u\left(L_{E X, 8 h}\right)
$$

gdzie:

$\mathrm{U}$ - niepewność rozszerzona,

$\mathrm{k}$ - współczynnik rozszerzenia $(\mathrm{k}=1,65)$. 


\section{Wyniki i ich omówienie}

Hałas generowany w trakcie pracy maszyny powinien być kontrolowany, aby możliwe było określenie narażenia na ten czynnik pracowników je obsługujących. Wyniki prowadzonych pomiarów przedstawiono w tabeli 2 .

Tabela 2. Wyniki pomiarów hałasu w trakcie pracy urządzenia [dB]

\begin{tabular}{|l|c|c|c|}
\hline \multicolumn{1}{|c|}{ Wykonywane czynności } & LAeq & Lmax & L $_{\text {CPEAK }}$ \\
\hline \multirow{2}{*}{ Nabieranie kruszywa } & 70,8 & 81,6 & 106,0 \\
(0-31,5) tzw. mieszanka & 71,0 & 81,3 & 106,5 \\
& 71,5 & 82,0 & 105,7 \\
\hline \multirow{2}{*}{ Nabieranie kamieni thuczeń (31,5-63) } & 69,5 & 81,6 & 106,0 \\
& 70,0 & 80,9 & 106,0 \\
\multirow{2}{*}{ Sypanie kruszywa na przyczepę } & 71,5 & 81,0 & 106,5 \\
\hline \multirow{2}{*}{ Cała czynność dla kruszywa } & 70,4 & 78,7 & 106,9 \\
& 71,0 & 79,0 & 107,0 \\
& 70,7 & 78,0 & 106,5 \\
\hline
\end{tabular}

Pomiary hałasu wykonano w trakcie pracy koparki podczas nabierania kruszywa o różnych rozmiarach i zsypywaniu na przyczepę do dalszego transportu zamawiającego. Najwyższy poziom hałasu, określony jako równoważny poziom dźwięku, odnotowano w trakcie nabierania kruszywa i wynosił 71,5 dB. Maksymalny poziom dźwięku również był najwyższy w trakcie nabierania kruszywa $(82 \mathrm{~dB})$, zaś najwyższą wartość dla szczytowego poziomu dźwięku uzyskano w trakcie sypania kruszywa na przyczepę $(107 \mathrm{~dB})-($ tab. 2).

Do oceny narażenia na hałas kierowcy ładowarki uwzględniono 3 czynności:

- łącznie czynność operacja dla kruszywa - czynność 1 ;

- jazda do przodu - czynność 2 ;

- jazda do tyłu - czynność 3.

Uzyskane wyniki analizowano z wykorzystaniem PN-N-01307:1994, a następnie odniesiono je do normy ISO-9612.

Na podstawie powyższych danych możemy stwierdzić, że poziom hałasu podczas wykonywania pomiarów przy wszystkich czynnościach wynosił od $66 \mathrm{~dB}$ do 71,5 dB, a dzienny poziom ekspozycji na hałas wynosił 69,2 dB. Podobnie kształtuje się sytuacja przy poziomie maksymalnym i szczytowym, których zakres wynosił odpowiednio 72,181,6 dB i 105-107 dB. Tym samym porównując te wartości z wartościami normatywnymi możemy stwierdzić, że nie zostały one przekroczone. Najwyższy poziom hałasu miał miejsce przy nabieraniu kruszywa i kamienia oraz jego sypaniu na przyczepę, jednakże mimo że był on najwyższy i tak daleko mu było do przekroczenia minimalnych wartości normatywnych. 
Tabela 3. Dzienny poziom ekspozycji na hałas wraz z niepewnością pomiarów wg ISO 9612:2009

\begin{tabular}{|c|c|c|c|c|c|}
\hline \multicolumn{2}{|r|}{ Wyniki } & Nazwa czynności & Czynność 1 & Czynność 2 & Czynność 3 \\
\hline \multicolumn{2}{|c|}{ Średni poziom hałasu $(\mathrm{dB})$} & $\mathrm{L}_{\mathrm{p}, \mathrm{A}, \mathrm{eq} T, \mathrm{~m}}$ & 69,7 & 66,6 & 68,1 \\
\hline \multicolumn{2}{|c|}{ Średni czas trwania $(\mathrm{h})$} & $\mathrm{Tm}$ & 6,5 & 0,5 & 0,5 \\
\hline \multicolumn{2}{|c|}{ Udział czynności m w Lex,8h } & $\mathrm{L}_{\mathrm{EX}, 8 \mathrm{~h}, \mathrm{~m}}$ & 69,1 & 54,8 & 56,4 \\
\hline \multirow{7}{*}{$\begin{array}{l}\text { Udział } \\
\text { niepewności }\end{array}$} & Poziom hałasu & $\left(\mathrm{c}_{1 \mathrm{a}, \mathrm{m}} * \mathrm{u}_{1 \mathrm{a}, \mathrm{m}}\right)^{2}$ & 0,02 & 0,00 & 0,00 \\
\hline & $\begin{array}{l}\text { Czas trwania } \\
\text { czynności }\end{array}$ & $\left(\mathrm{c}_{1 \mathrm{~b}, \mathrm{~m}} * \mathrm{u}_{1 \mathrm{~b}, \mathrm{~m}}\right)^{2}$ & 0,00 & 0,00 & 0,00 \\
\hline & $\begin{array}{l}\text { Wyposażenie } \\
\text { pomiarowe }\end{array}$ & $\left(\mathrm{c}_{1 \mathrm{a}, \mathrm{m}} * \mathrm{u}_{2, \mathrm{~m}}\right)^{2}$ & 1,89 & 0,00 & 0,01 \\
\hline & Pozycja pomiarowa & $\left(\mathrm{c}_{\mathrm{la}, \mathrm{m}} * \mathrm{u}_{3}\right)^{2}$ & 0,84 & 0,00 & 0,00 \\
\hline & $\begin{array}{l}\text { Suma } \\
\text { dla każdej czynności m }\end{array}$ & $\mathrm{u}^{2}\left(\mathrm{~L}_{\mathrm{EX}, 8 \mathrm{~h}}\right) \mathrm{m}$ & 2,75 & 0,00 & 0,01 \\
\hline & $\begin{array}{l}\text { Suma } \\
\text { dla wszystkich czynności }\end{array}$ & $\mathrm{u}^{2}\left(\mathrm{~L}_{\mathrm{EX}, 8 \mathrm{~h}}\right)=$ & 2,76 & & \\
\hline & $\begin{array}{l}\text { Złożona } \\
\text { niepewność standardowa }\end{array}$ & $\mathrm{u}\left(\mathrm{L}_{\mathrm{EX}, 8 \mathrm{~h}}\right)$ & $1,7 \mathrm{~dB}$ & \multicolumn{2}{|c|}{ niepewność rozszerzona } \\
\hline \multicolumn{2}{|c|}{ Dzienny poziom ekspozycji na hałas } & $\mathrm{L}_{\mathrm{EX}, 8 \mathrm{~h}}=$ & $69,2 \mathrm{~dB}$ & \multicolumn{2}{|c|}{$\mathrm{U}\left(\mathrm{L}_{\mathrm{EX}, 8 \mathrm{~h}}\right)=1,65 * \mathrm{u}\left(\mathrm{L}_{\mathrm{EX}, 8 \mathrm{~h}}\right)=2,7$} \\
\hline
\end{tabular}

Prowadząc dalszą analizę tego czynnika w środowisku pracy, należy je odnieść do najwyższego dopuszczalnego natężenia w środowisku pracy, który w Rozporządzeniu został określony na poziomie $85 \mathrm{~dB}$ i obliczyć krotność $(K)$ wg poniższego wzoru.

$$
K=10^{\frac{L E X, 8 h-85 d B}{10}}
$$

Krotność $(K)$ przekroczenia dopuszczalnego poziomu (NDN) hałasu w zakresie słyszalnym dla analizowanego stanowiska pracy, przy $\mathrm{L}_{\mathrm{EX}, 8 \mathrm{~h}}=69,2 \mathrm{~dB}$ wynosi:

$$
K=0,04 \mathrm{~dB}
$$

Zgodnie $\mathrm{z}$ obowiązującym rozporządzeniem $\mathrm{w}$ trakcie obsługi ładowarki w objętym badaniami zakładzie pracy, nie ma przekroczeń wartości progu działania oraz wartości dopuszczalnych (85 NDS), co upoważnia do stwierdzenia że ryzyko jest na bardzo niskim poziomie, czyli ryzyko zawodowe jest dopuszczalne.

\section{Podsumowanie i wnioski}

Według przeprowadzonych badań można stwierdzić, że badana maszyna - ładowarka czołowa, zapewnia odpowiednie i bezpieczne warunki pracy dla korzystającego $\mathrm{z}$ niej operatora. Poziom hałasu $\mathrm{w}$ kabinie jest na tyle niski, że operator podczas pracy nie musi używać dodatkowych ochron słuchu, a praca w tym środowisku nie powinna 
powodować żadnych negatywnych skutków związanych z narządem słuchu w całym okresie pracy zawodowej.

Na podstawie prowadzonych badań stwierdzono:

1. Dzienny poziom ekspozycji na hałas operatora ładowarki wynosił $69,2 \mathrm{~dB}$ i nie przekraczał zalecanego poziomu;

2. Operator ładowarki w objętym badaniami zakładzie może bezpiecznie wykonywać swoje obowiązki.

\section{Bibliografia}

Boroń M., Pawlas K., Pawlas N., 2013. Hałas słyszalny i niskoczęstotliwościowy, Inst. Med. Pracy i Zdrowia Środowiskowego w Sosnowcu.

Dyrektywa 2002/49/WE Parlamentu Europejskiego i Rady z dnia 25 czerwca 2002 r. odnosząca się do oceny i zarządzania poziomem hałasu w środowisku.

Dyrektywa 89/656/EWG z dnia 30 listopada 1989 r., w sprawie minimalnych wymagań w dziedzinie bezpieczeństwa i ochrony zdrowia pracowników korzystających z wyposażenia ochronnego.

Ekert J., Czech P., Figlus T., Turoń K., Rozpondek M., 2018. Ocena hałasu wzdłuż wybranych tras komunikacyjnych aglomeracji górnośląskiej, Autobusy: Technika, Eksploatacja, Systemy Transportowe, 19 (6), 97-105.

Gardziejczyk W., 2010. Problem hałasu generowanego podczas robót drogowych na obszarach chronionych i na terenach zurbanizowanych, Przegląd Budowlany.

ISO 9612:2009 „Akustyka - Wyznaczanie zawodowej ekspozycji na hałas - Metoda techniczna”.

Leśnikowska-Matusiak I., Wnuk A., 2014. Wpływ hałasu komunikacyjnego na stan środowiska akustycznego człowieka, Transport Samochodowy 3, 37-62.

Mizierski W., 2004. Tablice Biologiczne, Adamantan, Warszawa.

Młyński R., Kozłowski E., 2016. Stosowanie indywidualnych ochron słuchu w przypadku hałasu o częstotliwościach słyszalnych powyżej $8 \mathrm{kHz}$, CIOP-PIB, Warszawa.

Obwieszczenie Ministra Gospodarki, Pracy i Polityki Społecznej z dnia 28 sierpnia 2003 r. w sprawie ogłoszenia jednolitego tekstu rozporządzenia Ministra Pracy i Polityki Socjalnej w sprawie ogólnych przepisów bezpieczeństwa i higieny pracy (Dz. U. 2003 nr 169, poz.1650).

Obwieszczenie Prezesa Rady Ministrów z dnia 4 września 2013 r. w sprawie ogłoszenia jednolitego tekstu rozporządzenia Rady Ministrów w sprawie chorób zawodowych (Dz. U. 2013 poz. 1367).

Pleban D., 2019. Hałas ultradźwiękowy - pomiary, ocena i zalecenia profilaktyki, CIOP-PIB, Warszawa.

PN-N-01307:1994. Hałas - Dopuszczalne wartości hałasu w środowisku pracy - Wymagania dotyczące wykonywania pomiarów.

Rabinowitz P.M., 2000. Noise-Induced Hearing Loss. Yale University School of Medicine, New Haven, Connecticut Am. Fam. Physician. 61(9), 2749-2756

Rozporządzenie Ministra Rodziny, Pracy i Polityki Społecznej z dnia 12 czerwca 2018 r. w sprawie najwyższych dopuszczalnych stężeń i natężeń czynników szkodliwych dla zdrowia w środowisku pracy (Dz.U. 2018 poz. 1286).

Rozporządzenie Ministra Zdrowia z dnia 2 lutego 2011 r. w sprawie badań i pomiarów czynników szkodliwych dla zdrowia w środowisku pracy (Dz.U. $2011 \mathrm{nr} 33$ poz. 166).

Rozporządzeniu Ministra Gospodarki i Pracy z dnia 5 sierpnia 2005 r. w sprawie bezpieczeństwa i higieny pracy przy pracach związanych $\mathrm{z}$ narażeniem na hałas lub drgania mechaniczne (Dz. U. $2005 \mathrm{nr} 157$ poz. 1318). 
Świątkowska B., Hanke W., Szeszenia-Dąbrowska N., 2020. Choroby zawodowe w Polsce w 2019 roku, Inst. Med. Pracy im. prof. J. Nofera, Centralny Rejestr Chorób Zawodowych, Łódź.

Woźniak J.W., 2015. Bariery w komunikacji interpersonalnej na stanowiskach pracy, Zesz. Nauk. Organizacja i Zarządzanie / Polit. Śląska, 79, 367-386.

Woźny A., Dobosz M., Pacana A., 2014. Wpływ hałasu na jakość pracy. Humanit. Social Sci. 21 (2), $251-258$. 
Dominika Kopiec $^{1,3}$, Karolina Kuzioła ${ }^{1}$, Bożena Nowakowicz-Dębek ${ }^{2}$

\section{Identyfikacja zagrożeń $\mathrm{i}$ ich analiza w środowisku pracy piekarza}

Identification of hazards and their analysis in the baker's work environment

Chleb jest bardzo ważnym produktem spożywczym, który dostarcza organizmowi wiele cennych składników odżywczych. Spożycie tego pieczywa rocznie na jedną osobę wynosi około $100 \mathrm{~kg}$. Polska charakteryzuje się dość dużym zróżnicowaniem pieczywa [Czerwińska i Piotrowski 2009]. Wypiekiem pieczywa zajmuje się osoba posiadająca odpowiednie kwalifikacje, przypisane w karcie zawodów piekarzowi. Praca piekarza polega na odpowiednim doborze surowców spożywczych oraz ich obróbce w celu uzyskania różnorodnego pieczywa. Zazwyczaj pieczywo występuje w postaci wyrobów takich jak: chleb, rogaliki oraz innych powstających na bazie jajek, masła i mleka. Piekarz wykonuje swoją pracę głównie na hali produkcyjnej, jednak część swojego czasu spędza również w magazynie. W bardziej rozwiniętych technologicznie zakładach piekarz wykonuje swoje obowiązki również w mroźni, gdzie temperatura może osiągać $30^{\circ} \mathrm{C}$. Jednym $\mathrm{z}$ etapów produkcji pieczywa jest rozrost ciasta, oznacza to, że surowe wyroby są przechowywane $\mathrm{w}$ specjalnym pomieszczeniu nazywanym garownią. Temperatura tam osiąga nawet $+50^{\circ} \mathrm{C}$. Do odpowiedniego wzrostu ciasta istotna jest również optymalna wilgotność powietrza. Warto zwrócić uwagę na zakres czynności piekarza oraz związane z nimi zagrożenia. Pracownik piekarni odpowiedzialny jest za przygotowanie surowców potrzebnych w kolejnych etapach produkcji pieczywa. Zajmuje się wyrabianiem ciasta, formowaniem kęsów, wypiekaniem surowych kęsów w piecach, krojeniem pieczywa $\mathrm{w}$ specjalnych krajalnicach oraz pakowaniem $\mathrm{w}$ foliowe opakowania [Orlak i Gudalewicz 2011]. Branża piekarnicza jest to zróżnicowane środowisko pracy, które ma wpływ na bezpieczeństwo pracowników. Obecnie funkcjonujące piekarnie to obiekty, gdzie pracuje od kilku do kilkunastu pracowników. Są to zakłady w niewielkim stopniu zmechanizowane. Występują także zakłady, które posiadają nowoczesne systemy produkcji, pełne linie do wypieku. W każdym z tych zakładów występują zagrożenia, które wpływają na jakość pracy. Należy tutaj wymienić wysoką temperaturę i wilgotność, zapylenie powietrza pyłami mącznymi oraz pyłami cukru, hałas wydobywający się z urządzeń piekarskich czy ditlenek węgla ulatniający się z ciasta w stanie aktywnej fermentacji, co może prowadzić do trudności z oddychaniem. Wśród istotnych zagrożeń $\mathrm{w}$ tej branży należy również wymienić pracę zmianową i obciążenie układu mięśniowo-szkieletowego [Orlak i Gudalewicz 2011, Parfianowicz 2015].

\footnotetext{
${ }^{1}$ Studenckie Koło Naukowe Nauk o Zwierzętach i Biogospodarki; Sekcja Higieny Pracy

${ }^{2}$ Uniwersytet Przyrodniczy w Lublinie, Wydział Nauk o Zwierzętach i Biogospodarki, Katedra Higieny Zwierząt i Zagrożeń Środowiska

${ }^{3}$ dominikakopiec4683@gmail.com
} 


\section{Pyły jako główne zagrożenie pracy w piekarni}

Jednym z istotnych czynników wpływających negatywnie na stan zdrowia piekarzy jest zapylenie powietrza wynikające z obecności głównie pyłu mąki. Zgodnie z definicją, pyłem określa się różnej wielkości cząstki ciał stałych, które przez pewien czas unoszą się w powietrzu. Natomiast według normy PN-ISO 4225:1999, pył stanowi zawiesinę cząstek stałych, ciekłych lub stałych i ciekłych w fazie gazowej o pomijalnej prędkości opadania. W swoim składzie zawiera zarówno substancje organiczne, jak i nieorganiczne stanowiące poważne zagrożenie dla zdrowia osób przebywających w zapylonym pomieszczeniu [Czekaj 2011]. Ze względu na wielkość cząsteczek, dzielimy je, na pyły całkowite, respirabilne oraz inhalabilne. Pyłem całkowitym nazywamy wszystkie cząstki zawieszone w określonej objętości powietrza, natomiast pył inhalabilny charakteryzuje się średnicą cząstek pyłu mniejszą niż $10 \mu \mathrm{m}$. Najbardziej szkodliwy jednak jest pył respirabilny, który dociera do pęcherzyków płucnych i odpowiada za rozwój pylicy płuc. Ze względu na stopień wnikania pyłów do organizmu oraz znaczenia rozmiaru cząstek wyróżnione zostały odpowiednie frakcje pyłowe. Frakcje wdychaną stanowią wszystkie cząstki pyłu wdychane przez usta i nos. Część frakcji wdychanej niedocierającej poza krtań określa się mianem frakcji pozatchawicznej, natomiast część frakcji wdychanej wnikająca poza krtań nazywa się frakcją tchawiczą. Wyodrębniono również frakcję tchwiczno-oskrzelową, w której cząstki pyłu wnikają poza krtań, lecz nie docierają do części pęcherzyków płucnych. Ze względu na zmiany płucne, jakie mogą powodować pyły, wyróżniono te o działaniu zwłókniającym mające destrukcyjny wpływ na pęcherzyki płucne, a co za tym idzie rozwój pylicy kolagenowej płuc, oraz pyły niezwłókniające, których działanie jest mniej szkodliwe dla płuc, jednak również powodują pylice niekolagenowe. Pyły mają znaczący wpływ na organizm człowieka. Ze względu na rodzaj działania biologicznego, szkodliwego wyróżniamy działanie pylicotwórcze, alergizujące, drażniące, toksyczne, rakotwórcze oraz radioaktywne [Czekaj 2011].

W powietrzu atmosferycznym oraz obiektach przemysłowych przeważają pyły pochodzenia nieorganicznego, zaś w budynkach przeznaczonych dla ludzi i zwierząt pyły pochodzenia organicznego. Źródła zapylenia w środowisku pracy są bardzo różnorodne, najczęściej jednak wynikają $\mathrm{z}$ określonego procesu technologicznego $\mathrm{w}$ danym zakładzie pracy. Piekarnia jest pierwszorzędnym przykładem środowiska pracy, gdzie pracownik ma styczność głównie z pyłem mącznym i cukrowym, gdyż są to podstawowe składniki wyrobów piekarskich. Pszenica jest jednym z najczęściej używanych ziaren w przemyśle piekarskim. Pył mąki jest wynikiem bardzo drobnego zmielenia ziaren roślin zbożowych oraz niezbożowych. Mąka zbożowa w swoim składzie nie zawiera wyłącznie zmielonego ziarna pszenicy. W trakcie procesu powstawania mąki do niej dodawane są składniki mające na celu poprawę jakości wyrabianego z niej ciasta, są to głównie enzymy, jak a-amylaza, celulaza, proteaza, lipaza, jak też dodatki piekarnicze: drożdże piekarnicze, aromaty, przyprawy czy konserwanty. Często notuje się tam obecność roztoczy, grzybów i mykotoksyn, które są szczególnie niebezpieczne dla zdrowia pracowników piekarni [Stobnicka-Kupiec i Górny 2017]. Jednym z istotnych następstw czy skutków narażenia piekarzy na pył mąki są problemy w obrębie układu oddechowego objawiające się alergicznym zewnątrzpochodnym zapaleniem pęcherzyków płucnych, tzw. płuco piekarza, często nazywane pylicą płuc oraz astma zawodowa [Czekaj 2011, Health and Safety Executive 2013, Stobnicka-Kupiec i Górny 2017]. U pracowników piekarni występuje często także zapalenie spojówek, nieżyt nosa i reakcje skórne. $\mathrm{Na}$ pojawienie się astmy wpływ ma zawarta w pyle mąki grzybowa $\alpha$-amylaza pocho- 
dząca z zainfekowanego grzybem Aspergillus zboża. Najczęściej poprzedza ją zapalenie błony śluzowej nosa. Narażenie na pyły uwidacznia się również w patologicznym ścieraniu się szkliwa zębów [Stobnicka-Kupiec i Górny 2017]. Obecność pyłu mąki w powietrzu piekarni stwarza ryzyko wybuchu. Prusiel i Łapko [2011] podają dolną granicę wybuchowości pyłu mąki na poziomie $20 \mathrm{~g} / \mathrm{m}^{3}$, zaś za górną przyjęto stężenie $1000 \mathrm{~g} / \mathrm{m}^{3}$ [Prusiel i Łapko 2011]. Dlatego ważne jest podjęcie odpowiednich działań, które minimalizują ryzyko wystąpienia atmosfery wybuchowej oraz przyczyniają się do zwiększenia bezpieczeństwa pracowników piekarni [Parfianowicz 2015].

\section{Mikroklimat w piekarni}

Zakład piekarniczy charakteryzuje się specyficznym mikroklimatem, który może mieć negatywny wpływ na pracę oraz zdrowie pracowników. Piekarz odczuwa znaczące zmiany temperatur $\mathrm{w}$ trakcie zmiany roboczej ze względu na wykonywanie większości prac w bliskim otoczeniu pieca, a także w magazynie czy mroźni. Warunki środowiska charakteryzowane są poprzez mikroklimat gorący i zimny. Do określenia typu mikroklimatu wykorzystywane są dwa czynniki: temperatura powietrza oraz względna wilgotność powietrza. W badanym środowisku pracy dominuje mikroklimat gorący, który charakteryzuje się występowaniem temperatury powietrza powyżej $30^{\circ} \mathrm{C}$, a wartość względnej wilgotności powietrza utrzymuje się powyżej $65 \%$. Piec wykorzystywany do wypieku pieczywa ze względu na emitowanie promieniowania podczerwonego ma zasadniczy wpływ na temperaturę w hali produkcyjnej, dlatego też jest on brany pod uwage przy ocenie mikroklimatu. W mroźni natomiast występuje mikroklimat zimny, gdzie temperatura powietrza stale nie przekracza $0^{\circ} \mathrm{C}$ a wilgotność powietrza utrzymuje się na wysokim poziomie [Sudoł-Szopińska i in. 2006b]. Warunki mikroklimatyczne mają znaczący wpływ na wydajność, zdrowie i ogólne samopoczucie pracowników dlatego niezmiernie ważne jest stosowanie odpowiednich środków profilaktycznych. Organizm ludzki utrzymuję stałą temperaturę ciała, która wynosi $37^{\circ} \mathrm{C}$. W zależności od warunków otoczenia wykorzystuje swoją zdolność termoregulacji. Prawidłowe warunki mikroklimatyczne $\mathrm{w}$ pomieszczeniu roboczym to takie, w których temperatura powietrza wynosi $16^{\circ} \mathrm{C}$, wilgotność względna powietrza nie przekracza $60 \%$, a prędkość ruchu powietrza wynosi $0,3 \mathrm{~m} / \mathrm{s}$ [Chowański 1992]. W pomieszczeniach pracy, w których występuje mikroklimat gorący, ważne jest zapewnienie wymiany powietrza w celu skorygowania temperatury panującej wewnątrz zakładu, a także usunięcia zanieczyszczeń gazowych [Parfianowicz 2013]. Należy zwrócić uwagę na zmiany, jakie powoduje $\mathrm{w}$ organizmie pracowników przebywanie w gorącym środowisku pracy. Pogorszenie samopoczucia oraz brak skupienia pojawiają się już przy temperaturze $25^{\circ} \mathrm{C}$. Najwięcej zmian w sprawności wykonywania wszelkich czynności podczas zmiany roboczej ma miejsce przy temperaturze około $35^{\circ} \mathrm{C}$. Zdaniem Sudoł-Szopińskiej oraz Łuczak [2006a], najczęściej do popełniania błędów przy pracy dochodzi przy temperaturze powietrza między 33 a $35^{\circ} \mathrm{C}$.Wtedy też pojawiają się psychofizjologiczne zaburzenia organizmu [Sudoł-Szopińska i Łuczak 2006a]. Podwyższona temperatura w pomieszczeniu pracy przy braku odpowiedniej wentylacji powietrza może prowadzić m.in. do omdlenia, wyczerpania, kurczy cieplnych czy udaru pracowników piekarni [Parfianowicz 2015]. Wydłużenie czasu pracy w gorącym środowisku może zwiększać ryzyko występowania chorób zawodowych wynikających z dużego obciążenia układu krwionośnego człowieka [Bartkowiak i in. 2012]. 


\section{Czynniki chemiczne na stanowisku pracy piekarza}

Czynniki chemiczne występujące w środowisku pracy dzielimy według rodzaju działania na organizm i sposobu wchłaniania. W grupie pierwszej wyróżniamy substancje mutagenne, rakotwórcze, uczulające, toksyczne, drażniące, działające szkodliwie na funkcje rozrodcze i płodność. Uwzględniając natomiast sposób wchłaniania substancji do organizmu w środowisku pracy należy wymienić: drogi oddechowe, skórę i błony śluzowe, a także przewód pokarmowy [Mamot 2018]. W pomieszczeniach pracy powietrze istotnie różni się od powietrza atmosferycznego. Skład jego zależy od specyfiki produkcji, przebiegu procesu technologicznego, stosowanej wentylacji, wykonywanych czynności przez pracowników czy też wzajemnych interakcji substancji w mieszaninie zanieczyszczeń [Zabiegała 2009]. Wśród istotnych zanieczyszczeń powietrza wymienia się: tlenek węgla, ditlenek węgla, metan, tlenki azotu, tlenek diazotu, ditlenek siarki, amoniak, siarkowodór oraz lotne zanieczyszczenia organiczne - LZO [Sala i Zinko 2010]. Obecność ich w powietrzu może niekorzystnie wpływać na pracownika, przejawiając się kaszlem, podrażnieniem błon śluzowych, oczu, nosa, a także zaburzeniami w oddychaniu. W wysokich stężeniach mogą powodować uszkodzenia płuc, a nawet prowadzić do śmierci [Zabiegała i in. 2003]. Skład powietrza wewnątrz piekarni w dużym stopni zależy od przyjętej technologii wypieku. W piekarniach tradycyjnych wykorzystywane są jeszcze piece węglowe, natomiast w zmodernizowanych zakładach wykorzystywane są piece zasilane olejem opałowym, gazem bądź prądem.

\section{Cel pracy}

W środowisku pracy piekarzy występuje wiele zagrożeń, dlatego aby praca była tam bezpieczna, konieczna jest identyfikacja zagrożeń i ich analiza, co pozwoli na dostosowanie odpowiednich środków profilaktycznych.

\section{Material i metody badań}

Badania przeprowadzono w $2021 \mathrm{r}$. w jednej z lubelskich piekarni w trakcie trwania wypieku pieczywa na nocnej zmianie. Jest to niewielka piekarnia o powierzchni ok. $150 \mathrm{~m}^{2}$, w której pracuje łącznie pięciu piekarzy oraz jedna osoba na stanowisku kierownika. Trzech piekarzy pracuje na zmianie dziennej, natomiast dwóch na zmianie nocnej. Maszyny, które są wykorzystywane to głównie mieszarka do ciasta, piec węglowy, dzielarko-zaokrąglarka do bułek. Pracownicy dysponują również dwiema dużymi stolnicami do wyrabiania ciasta. Pieczywo jest wypiekane tradycyjnym sposobem $\mathrm{w}$ węglowym piecu według dawnych receptur, również na zakwasie. Asortyment, który oferuje piekarnia, nie jest tak bogaty jak w nowoczesnych, zmechanizowanych piekarniach. Swoim klientom oferuje podstawowe pieczywo takie jak chleb zwykły i razowy, bułki kajzerki, niewielkie ilości pączków i drożdżówek. W zakładzie tym piekarze korzystają głównie z mąki pszennej typu 500 oraz żytniej typu 720 . Według obliczeń, łączne zapotrzebowanie na mąkę wynosi ok. 2 ton tygodniowo.

$\mathrm{W}$ badaniu zapylenia powietrza w piekarni na hali produkcyjnej wykorzystano fotoczuły pyłomierz DustTrak (fot. 1). 


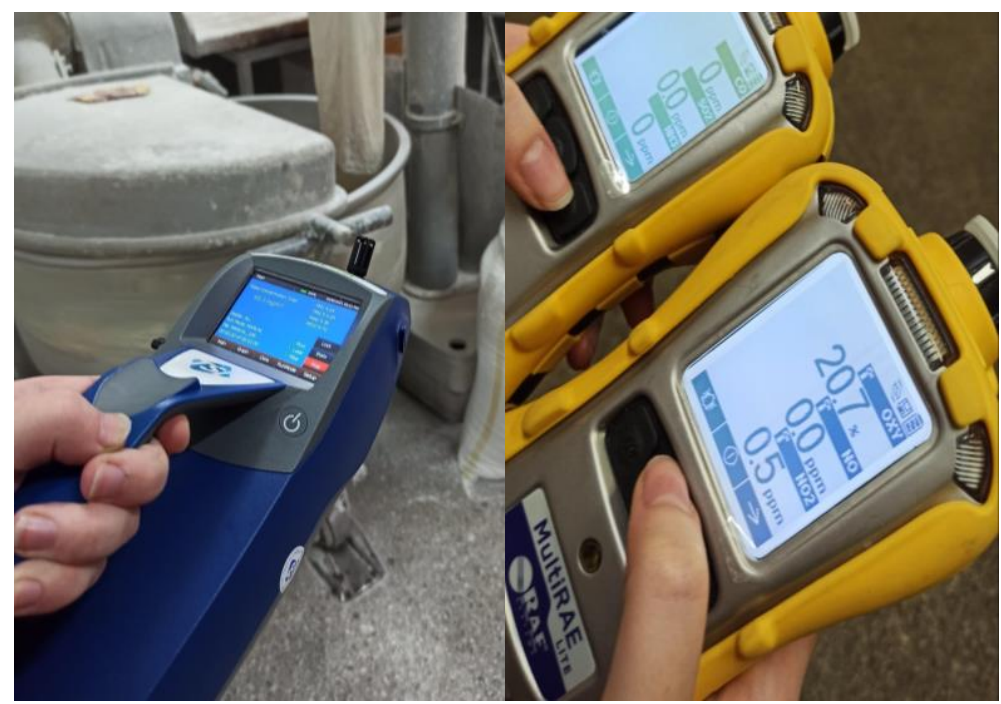

Fot. 1. Pomiar zapylenia w piekarni (z lewej) i pomiar czynników chemicznych (z prawej), (fot. własna)

Zastosowanie tego miernika pozwoliło na pomiar stężenia pyłu z podziałem na frakcje PM1, PM2.5, PM10, pył respirabilny oraz pył całkowity, tzw. frakcję wdychalną. Koncentrację uwalnianych substancji gazowych w powietrzu piekarni prowadzono za pomocą aspiratorów RAE SYSTEMS MultiRAE Lite oraz stacji pomiarowej wyposażonej w czujniki PID oraz $\mathrm{H}_{2} \mathrm{~S}$ (fot. 1). W trakcie badań kontrolowano parametry mikroklimatyczne panujące w piekarni za pomocą termohigrometru CEM DT321 i anemometru Hot Air PL135. Wyniki pomiarów opracowano i zestawiono w tabelach i na rycinach.

\section{Wyniki i ich omówienie}

Koncentracja dopuszczalnych stężeń substancji chemicznych (NDS) w środowisku pracy została przedstawiona w Rozporządzeniu Ministra Pracy i Polityki Społecznej w sprawie najwyższych dopuszczalnych stężeń i natężeń czynników szkodliwych dla zdrowia w środowisku pracy z dnia 12 czerwca 2018 r. (Dz.U. 2018 poz. 1286 ze zm.). Wyniki pomiarów koncentracji zanieczyszczeń chemicznych, pyłów oraz parametrów mikroklimatycznych zostały przedstawione kolejno na ryc. 1 oraz w tabelach 1, 2 i 3 . Niestety nie dla wszystkich substancji został określony NDS.

Pomiary lotnych zanieczyszczeń środowiskowych (PID) i siarkowodoru $\left(\mathrm{H}_{2} \mathrm{~S}\right)$ zarejestrowane zostały przez stację pomiarową. Urządzenie usytuowano w hali produkcyjnej, a łączny czas pomiarów wynosił 3 godz. Analizując zamieszczone na wykresie (ryc. 1) wyniki, można stwierdzić, że zawartość siarkowodoru w powietrzu jest znikoma, natomiast koncentracja lotnych zanieczyszczeń środowiskowych utrzymuje się na stałym poziomie pomiędzy 4 a 5 ppm. Zanieczyszczenia powietrza w środowisku pracy piekarza głównie powstają z pieca. 


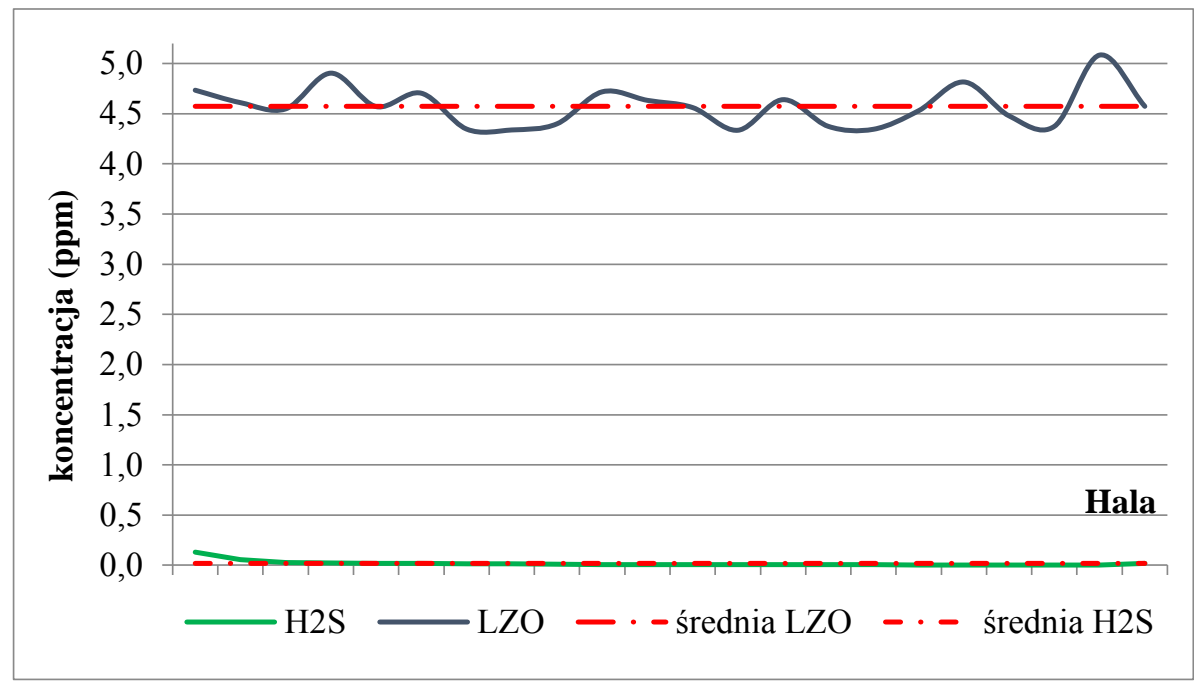

Ryc. 1. Koncentracja PID i $\mathrm{H}_{2} \mathrm{~S}$ w powietrzu piekarni (ppm)

Tabela 1. Koncentracja pyłu w powietrzu piekarni w trakcie pomiarów $\left(\mathrm{mg} / \mathrm{m}^{3}\right)$

\begin{tabular}{|c|c|c|c|}
\hline $\begin{array}{c}\text { Punkty } \\
\text { pomiarowe }\end{array}$ & $\begin{array}{l}\text { Wartości } \\
\text { mierzone }\end{array}$ & Wyniki & Czynności \\
\hline \multirow{20}{*}{ Hala } & PM1 & 0,69 & \multirow{5}{*}{$21: 14$ w trakcie wypiekania chleba } \\
\hline & PM2,5 & 0,70 & \\
\hline & Respirabilny & 0,72 & \\
\hline & PM10 & 1,15 & \\
\hline & Pyl calkowity & 5,88 & \\
\hline & PM1 & 0,33 & \multirow{5}{*}{ 22:02 w trakcie ważenia składników } \\
\hline & PM2,5 & 0,34 & \\
\hline & Respirabilny & 0,34 & \\
\hline & PM10 & 0,39 & \\
\hline & Pyl całkowity & $\mathbf{0 , 5 5}$ & \\
\hline & PM1 & 8,59 & \multirow{5}{*}{ 22:07 w trakcie mieszania ciasta } \\
\hline & PM2,5 & 8,60 & \\
\hline & Respirabilny & 8,65 & \\
\hline & PM10 & 12,30 & \\
\hline & Pył całkowity & 117,00 & \\
\hline & PM1 & 4,40 & \multirow{5}{*}{$22: 16$ w trakcie ręcznego wyrabiania ciasta } \\
\hline & PM2,5 & 4,41 & \\
\hline & Respirabilny & 4,53 & \\
\hline & PM10 & 9,73 & \\
\hline & Pyl calkowity & 72,40 & \\
\hline
\end{tabular}




\begin{tabular}{|c|c|c|c|}
\hline \multirow{11}{*}{ Hala } & $\begin{array}{l}\text { PM1 } \\
\text { PM2,5 } \\
\text { Respirabilny } \\
\text { PM10 } \\
\text { Pyl calkowity }\end{array}$ & \begin{tabular}{c|}
3,79 \\
3,80 \\
3,84 \\
7,71 \\
$\mathbf{5 0 , 8 0}$ \\
\end{tabular} & 22:26 po wyjęciu pieczywa z pieca \\
\hline & PM1 & 0,52 & \\
\hline & PM2,5 & 0,52 & \\
\hline & Respirabilny & 0,53 & 23:39 w trakcie posypywania form mąką \\
\hline & PM10 & 0,94 & \\
\hline & Pyl całkowity & 5,52 & \\
\hline & PM1 & 0,10 & \\
\hline & PM2,5 & 0,10 & \\
\hline & Respirabilny & 0,10 & $\begin{array}{l}\text { 25:18 w trakcie krojenia cnieba i pakowania } \\
\text { do wysyłki }\end{array}$ \\
\hline & PM10 & 0,10 & \\
\hline & Pył calkowity & 0,18 & \\
\hline \multirow{10}{*}{ Magazyn } & PM1 & 0,17 & \multirow{5}{*}{$\begin{array}{l}\text { 23:20 pomiar w miejscu przechowywania } \\
\text { worków z mąką }\end{array}$} \\
\hline & PM2,5 & 0,17 & \\
\hline & Respirabilny & 0,17 & \\
\hline & PM10 & 0,19 & \\
\hline & Pyl calkowity & $\mathbf{0 , 2 3}$ & \\
\hline & PM1 & 0,15 & \multirow{5}{*}{$\begin{array}{l}\text { 23:22 pomiar obok jednej z maszyn } \\
\text { do mieszania ciasta przechowywanej } \\
\text { w magazynie }\end{array}$} \\
\hline & PM2,5 & 0,15 & \\
\hline & Respirabilny & 0,15 & \\
\hline & PM10 & 0,16 & \\
\hline & Pyl całkowity & $\mathbf{0 , 2 1}$ & \\
\hline
\end{tabular}

Pomiar pyłów w powietrzu prowadzono w trakcie rutynowych czynności wykonywanych przez pracowników piekarni. Największe zapylenie w piekarni odnotowano na hali w trakcie mieszania ciasta do wypieku pieczywa. Koncentracja pyłu całkowitego wynosiła wówczas $117 \mathrm{mg} / \mathrm{m}^{3}$, a pył respirabilnego $8,65 \mathrm{mg} / \mathrm{m}^{3}$ (tab. 1). Natomiast stężenie pyłu o średnicy $1 \mu \mathrm{m}$ (PM1), 2,5 $\mu \mathrm{m}$ (PM2,5) i $10 \mu \mathrm{m}$ (PM10) wynosiło odpowiednio $8,59 \mathrm{mg} / \mathrm{m}^{3}, 8,6 \mathrm{mg} / \mathrm{m}^{3}$ i $12,3 \mathrm{mg} / \mathrm{m}^{3}$. Podczas krojenia chleba i pakowania do wysyłki uzyskano najniższą koncentrację pyłów dla wszystkich frakcji $-0,10 \mathrm{mg} / \mathrm{m}^{3}$. Wyjątek stanowił pył respirabilny $0,17 \mathrm{mg} / \mathrm{m}^{3}$, natomiast poziom pyłu całkowitego wynosił $0,18 \mathrm{mg} / \mathrm{m}^{3}$. Średnia koncentracja pyłu całkowitego w powietrzu hali badanej piekarni wynosiła $36,05 \mathrm{mg} / \mathrm{m}^{3}$ (ryc. 2). Dla poszczególnych frakcji w hali uzyskano następujące wartości: $2,63 \mathrm{mg} / \mathrm{m}^{3}$ (PM1), 2,64 mg/m $\mathrm{m}^{3}$ (PM2,5), 2,67 mg/m (respirabilny), $4,62 \mathrm{mg} / \mathrm{m}^{3}$ (PM10). W magazynie wykonano dwa pomiary, które wykazały nieznaczne różnice dla poszczególnych frakcji. Średnia koncentracja pyłu całkowitego wynosiła $0,22 \mathrm{mg} / \mathrm{m}^{3}$, PM10 $-0,18 \mathrm{mg} / \mathrm{m}^{3}$, a pyłu PM1, PM2,5, respirabilnego $0,16 \mathrm{mg} / \mathrm{m}^{3}$. 


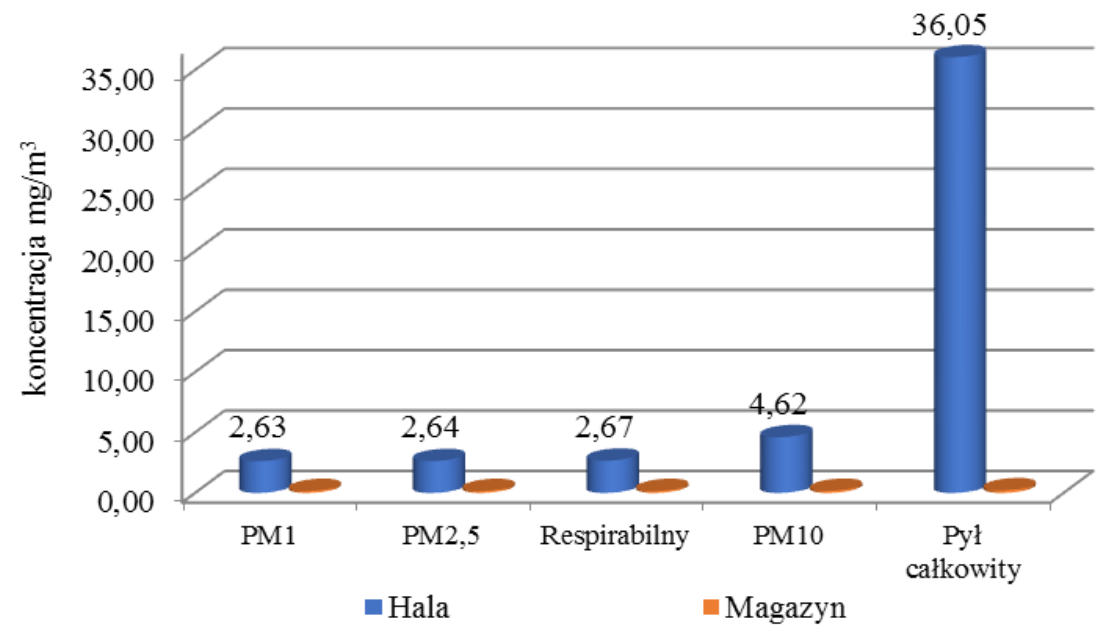

Ryc. 2. Średnia koncentracja pyłu w piekarni $\left(\mathrm{mg} / \mathrm{m}^{3}\right)$

Pomiary przeprowadzono w głównej hali produkcyjnej, ze względu na skupienie pracy piekarzy w tym miejscu. W hali wykonano 14 pomiarów pomiędzy godziną 20:57 a 22:30, zaś w magazynie 3 (tab. 2).

Odnotowano niewielkie zmiany temperatury w hali, a wartości wahały się od 24,1 do $28,1^{\circ} \mathrm{C}$. Średnia temperatura powietrza wyniosłą $27,0^{\circ} \mathrm{C}$, a wilgotność $36,7 \%$. Analizując wyniki badań wilgotności względnej powietrza, zaobserwowano $10 \%$ różnicę pomiędzy wartościami wskazanymi przez termohigrometr (tab. 2). Najwyższą średnią wilgotność względną uzyskano w magazynie 40,47\%, natomiast w hali 36,7\%. Ostatnim pomiarem $\mathrm{w}$ zakresie oceny mikroklimatu panującego $\mathrm{w}$ piekarni był ruch powietrza. Zaobserwowano stagnacje powietrza w piekarni. Jedyne zmiany jego poziomu wystąpiły w godzinach od 21:41 do $21: 43$. Średni ruch powietrza wynosił $0,03 \mathrm{~m} / \mathrm{s}$.

Tabela 2. Średnie wartości parametrów mikroklimatycznych w piekarni

\begin{tabular}{|l|c|c|c|}
\hline \multicolumn{1}{|c|}{ Punkty pomiarowe } & $\begin{array}{c}\text { Temperatura } \\
\left({ }^{\circ} \mathrm{C}\right)\end{array}$ & $\begin{array}{c}\text { Wilgotność względna } \\
(\%)\end{array}$ & $\begin{array}{c}\text { Ruch powietrza } \\
(\mathrm{m} / \mathrm{s})\end{array}$ \\
\hline Hala & 27,0 & 36,7 & 0,03 \\
\hline Magazyn & 21,7 & 40,47 & 0,00 \\
\hline
\end{tabular}

Tabela 3 przedstawia wyniki pomiarów koncentracji gazów w powietrzu w piekarni. Pierwszy pomiar przeprowadzono pomiędzy godziną 21:10 a 21:28 i obejmował dwie czynności wykonywane przez pracowników: wypiekanie chleba oraz wyrabianie ciasta na bułki. W trakcie tych czynności nie wykazano obecności $\mathrm{H}_{2} \mathrm{~S}, \mathrm{NH}_{4}, \mathrm{SO}_{2}$ i $\mathrm{NO}$ w powietrzu, a stężenie $\mathrm{CO}_{2}$ wynosiło $0,03 \%$ vol. (tab. 3). Podczas wypiekania chleba stężenie $\mathrm{NO}_{2}$ wynosiło $0,1 \mathrm{ppm}$, natomiast koncentracja lotnych zanieczyszczeń (PID) sięgała poziomu 5,2 ppm. W trakcie wyrabiania ciasta na bułki koncentracja $\mathrm{NO}_{2}$ oraz PID wynosiła kolejno 0,5 ppm i 5,2 ppm. Poziom tlenu utrzymywał zbliżone wartości 
Tabela 3. Koncentracja gazów w powietrzu piekarni w trakcie pomiarów

\begin{tabular}{|c|c|c|c|}
\hline \multicolumn{4}{|c|}{ Gazy } \\
\hline \multirow{20}{*}{$\begin{array}{c}\text { Pomiary } \\
\text { wykonane w hali } \\
\text { produkcyjnej }\end{array}$} & \multicolumn{3}{|c|}{ I pomiar, pomiędzy godziną 21:10 a 21:28 } \\
\hline & $\begin{array}{c}\text { czynność, w jakiej } \\
\text { zostały wykonane } \\
\text { pomiary }\end{array}$ & wypiekanie chleba & $\begin{array}{c}\text { wyrabianie ciasta } \\
\text { na bułki }\end{array}$ \\
\hline & $\mathrm{NO}_{2}$ & $0,1 \mathrm{ppm}$ & $0,5 \mathrm{ppm}$ \\
\hline & $\mathrm{H}_{2} \mathrm{~S}$ & $0,0 \mathrm{ppm}$ & $0,0 \mathrm{ppm}$ \\
\hline & $\mathrm{CO}_{2}$ & $0,03 \%$ vol. & $0,03 \%$ vol. \\
\hline & $\mathrm{NH}_{3}$ & $0,0 \mathrm{ppm}$ & $0,0 \mathrm{ppm}$ \\
\hline & $\mathrm{SO}_{2}$ & $0,0 \mathrm{ppm}$ & $0,0 \mathrm{ppm}$ \\
\hline & NO & $0,0 \mathrm{ppm}$ & $0,0 \mathrm{ppm}$ \\
\hline & $\mathrm{O}_{2}$ & $20,90 \%$ & $20,60 \%$ \\
\hline & PID & $5,3 \mathrm{ppm}$ & $5,2 \mathrm{ppm}$ \\
\hline & \multicolumn{3}{|c|}{ II pomiar, pomiędzy godziną 21:30 a 21:54 } \\
\hline & $\begin{array}{c}\text { czynność, w jakiej } \\
\text { zostały wykonane } \\
\text { pomiary }\end{array}$ & mieszanie ciasta na chleb & $\begin{array}{c}\text { wykładanie } \\
\text { upieczonego } \\
\text { chleba na wózek }\end{array}$ \\
\hline & $\mathrm{NO}_{2}$ & $0,0 \mathrm{ppm}$ & $0,0 \mathrm{ppm}$ \\
\hline & $\mathrm{H}_{2} \mathrm{~S}$ & $0,0 \mathrm{ppm}$ & $0,0 \mathrm{ppm}$ \\
\hline & $\mathrm{CO}_{2}$ & $0,03 \%$ vol. & $0,03 \%$ vol. \\
\hline & $\mathrm{NH}_{3}$ & $0,0 \mathrm{ppm}$ & $0,0 \mathrm{ppm}$ \\
\hline & $\mathrm{SO}^{2}$ & $0,0 \mathrm{ppm}$ & $0,0 \mathrm{ppm}$ \\
\hline & NO & $0,0 \mathrm{ppm}$ & $0,0 \mathrm{ppm}$ \\
\hline & $\mathrm{O}_{2}$ & $20,70 \%$ & $20,90 \%$ \\
\hline & PID & $6,1 \mathrm{ppm}$ & $7 \mathrm{ppm}$ \\
\hline \multirow{9}{*}{$\begin{array}{l}\text { Pomiar wykonany } \\
\text { w magazynie }\end{array}$} & \multicolumn{3}{|c|}{ I pomiar, pomiędzy godziną 23:35 a 23:38 } \\
\hline & \multicolumn{2}{|l|}{$\mathrm{NO}_{2}$} & $0,0 \mathrm{ppm}$ \\
\hline & $\mathrm{H}_{2} \mathrm{~S}$ & \multicolumn{2}{|c|}{$0,0 \mathrm{ppm}$} \\
\hline & $\mathrm{CO}_{2}$ & \multicolumn{2}{|c|}{$0,03 \%$ vol. } \\
\hline & $\mathrm{NH}_{3}$ & \multicolumn{2}{|c|}{$0,00 \mathrm{ppm}$} \\
\hline & $\mathrm{SO}_{2}$ & \multicolumn{2}{|c|}{$0,00 \mathrm{ppm}$} \\
\hline & NO & \multicolumn{2}{|c|}{$0,00 \mathrm{ppm}$} \\
\hline & \multirow{2}{*}{$\begin{array}{c}\mathrm{O}_{2} \\
\mathrm{PID}\end{array}$} & \multicolumn{2}{|c|}{$20,90 \%$} \\
\hline & & \multicolumn{2}{|c|}{$3,4 \mathrm{ppm}$} \\
\hline
\end{tabular}

podczas obydwu czynności i zamykał się w przedziale od 20,60\% do $20,90 \%$. W trakcie mieszania ciasta na chleb oraz wykładania upieczonego chleba na wózek, przeprowadzono kolejny pomiar $(21: 40-21: 54)$. Nie stwierdzono w powietrzu obecności $\mathrm{NO}_{2}$, $\mathrm{H}_{2} \mathrm{~S}, \mathrm{NH}_{4}, \mathrm{SO}_{2}$ oraz $\mathrm{NO}$, natomiast $\mathrm{CO}_{2}$ kształtowało się na poziomie $0,03 \%$ vol. Drugi pomiar nie wykazał dużych zmian w przypadku koncentracji tlenu w powietrzu, a róż- 
nica PID pomiędzy mieszaniem ciasta na chleb a wykładaniem upieczonego ciasta na wózek wynosiła 0,9 ppm (tab. 3). W magazynie obserwowano stabilnie utrzymujące się parametry mikroklimatyczne. Nie stwierdzono obecności $\mathrm{NO}_{2}, \mathrm{H}_{2} \mathrm{~S}, \mathrm{NH}_{4}, \mathrm{NO}_{2}$ i NO, a koncentracja $\mathrm{CO}_{2} \mathrm{i} \mathrm{O}_{2} \mathrm{~W}$ magazynie była taka sama jak na hali produkcyjnej i wynosiła odpowiednio: $0,03 \%$ vol. i $20,90 \%$.

W porównaniu z badaniami Prędeckiej i in. [2016], uzyskano zauważalne różnice pomiędzy średnią zawartością pyłu całkowitego, poziomem wilgotności oraz temperaturą. W świętokrzyskiej piekarni średnia zawartość pyłu wynosiła $0,776 \mathrm{mg} / \mathrm{m}^{3}$, a parametry mikroklimatyczne odpowiednio: wilgotność - 62,54\%, średnia temperatura $25,8^{\circ} \mathrm{C}$. W niektórych piekarniach stosowane są jeszcze tradycyjne metody pracy, co może wpływać na zwiększenie zapylenia. Średnia koncentracja pyłu całkowitego w powietrzu w badaniach własnych była wyższa $\left(36,05 \mathrm{mg} / \mathrm{m}^{3}\right)$, w porównaniu $\mathrm{z}$ badaniami Prędeckiej i in. [2016]. Istotnie niższe stężenia pyłu w piekarniach wykazali również Wlazło i in. [2020]. Prowadzone badania wskazują na konieczność modernizacji hali produkcyjnej $\mathrm{w}$ zakresie usprawnienia systemu wentylacji.

\section{Podsumowanie i wnioski}

Przeprowadzone badania w piekarni pozwoliły na ocenę tego środowiska pracy. Wykazano, że największym zagrożeniem w środowisku pracy piekarza jest zapylenie powietrza, zmieniające się w zależności od wykonywanych czynności. Kolejnym ważnym czynnikiem wpływającym na stan zdrowia i jakość pracy jest wysoka temperatura oraz nieznaczny ruch powietrza. Monitorowane zanieczyszczenia chemiczne powietrza nie stanowią istotnego zagrożenia. Analizując uzyskane wyniki, można stwierdzić, że w badanym środowisku pracy występują czynniki szkodliwe, których występowanie można ograniczyć poprzez zastosowanie odpowiednich środków ochrony zbiorowej, takich jak dostosowanie wentylacji czy klimatyzacji. Podjęcie tych kroków pozwoli zapewnić lepsze warunki pracy poprzez obniżenie stężenia pyłów oraz temperatury w tym środowisku pracy.

\section{Bibliografia}

Bartkowiak G., Marszałek A., Dąbrowska A., 2012. Obciążenie cieplne pracowników w gorącym środowisku pracy i sposoby jego redukcji. Bezpieczeństwo Pracy 10, 28-32.

Chowański T., 1992. Materiały szkoleniowe z zakresu bezpieczeństwa i higieny pracy dla nauczycieli akademickich. Mikroklimat w pomieszczeniach pracy. Wyd. UŁ, Łódź, 129-130.

Czekaj A., 2011. Identyfikacja czynników występujących w środowisku pracy będących przyczyną powstawania pylic wraz $\mathrm{z}$ określeniem ich wpływu na wystąpienie choroby zawodowej orac przedstawienie działań prewencyjnych w tym zakresie. Zakład Ubezp. Społ., Będzin, $22-28$

Czerwińska W., Piotrowski W., 2009. Technologiczne aspekty wypieku pieczywa z określeniem punktów krytycznych zanieczyszczeń mikrobiologicznych (surowiec, urządzenia, produkt). Ochrona Środowiska, Środkowo-Pomorskie Tow. Nauk. Ochrony Środ., Polit. Koszalińska, t. $11,449-464$.

Health and Safety Executive. Occupational Asthma in Great Britain (2013). Health and safety statistics for 2012/13 [www.hse.gov.uk/statistics/causdis/asthma].

Mamot A., 2018. Czynniki szkodliwe badania i pomiary, Państwowa Inspekcja Pracy, 5-6. 
Orlak K., Gudalewicz L., 2011. Zagrożenie psychospołeczne na stanowisku piekarza. Ocena ryzyka zawodowego. Psychologia Pracy. 53-56.

Parfianowicz P., 2013. Bezpieczna piekarnia. Mikroklimat gorący. Państwowa Inspekcja Pracy, Główny Inspektorat Pracy, Warszawa, 18-19.

Parfianowicz P., 2015. Bezpieczeństwo pracy w piekarni. Bezpieczeństwo Pracy 1, 14-17.

Prędecka A., Węgrzyn M., Sulak E., Sowa M., 2016. Badanie stężenia pyłu ogólnego na stanowisku pracy piekarza - studium przypadku. Zesz. Nauk. SGSP/Szkoły Głównej Służby Pożarniczej 59, 3, 121-135.

Prusiel J.A., Łapko A., 2011. Ocena zagrożenia eksplozją pyłów w silosach w świetle norm europejskich, XXV Konf. Naukowo-Technicznej „Awarie budowlane”, Szczecin-Międzyzdroje, t. 2.

Rozporządzenie Ministra Rodziny, Pracy i Polityki Społecznej z dnia 12 czerwca 2018 r. w sprawie najwyższych dopuszczalnych stężeń i natężeń czynników szkodliwych dla zdrowia w środowisku pracy (Dz.U. 2018 poz. 1286 ze zm.).

Sala S., Zinko I., 2010. Wybrane problemy zanieczyszczeń powietrza. Rocz. Świętokrzyski. Ser. B Nauki Przyr. 31, 73-84.

Stobnicka-Kupiec A., Górny R.L., 2017. Pyły mąki - frakcja wdychalna. Dokumentacja proponowanych dopuszczalnych wielkości narażenia zawodowego. Podstawy i Metody Oceny Środowiska Pracy 3(93), 95-120.

Sudoł-Szopińska I., Łuczak A., 2006a. Wpływ temperatury środowiska zewnętrznego na sprawność działania człowieka. Bezpieczeństwo Pracy 7-8, 16-19.

Sudoł-Szopińska I., Sobolewski A., Młożniak D., Konarska M., 2006b. Ocena niekorzystnego wpływu mikroklimatu - Centrum Badań Obciążeń Termicznych, Bezpieczeństwo Pracy 3, $20-23$.

Wlazło Ł., Nowakowicz-Dębek B., Chmielowiec-Korzeniowska A., Maksym P., Pawlak H., Kapica J., 2020. Assessment of the level of organic dust and mould spores in the work environment of baker. Indian J. Occup. Environ. Med. 24(3), 137-141, doi: 10.4103/ijoem.IJOEM 51_19.

Zabiegała B., Partyka M., Namieśnik J., 2003. Jakość powietrza wewnętrznego analityka i monitoring. W: Nowe horyzonty i wyzwania w analityce i monitoringu środowiskowym. Polit. Gdańska, $540-562$.

Zbiegała B., 2009. Jakość powietrza wewnętrznego - lotne związki organiczne jako wskaźnik jakości powietrza wewnętrznego. t. 2, 303-315, http://wis.pol.lublin.pl/kongres3/tom2/33.pdf [dostęp 13.02.2021]. 


\section{Gabriela Kosowska ${ }^{1,2}$, Katarzyna Karpińska ${ }^{1}$, Damian Jaguszewski ${ }^{1}$, Bożena Nowakowicz-Dębek ${ }^{1}$}

\section{Identyfikacja i analiza zagrożeń w małej gastronomii}

Identification and hazard analysis in gastronomy

Gastronomia to sektor gospodarki, zajmujący się usługami i prowadzeniem punktów żywienia zbiorowego. Główny Urząd Statystyczny (GUS) definiuje placówkę gastronomiczną jako zakład stały bądź sezonowy zajmujący się przygotowywaniem i sprzedażą dań i napojów zarówno na miejscu, jak i na wynos [stat.gov.pl]. Placówki gastronomiczne dzieli się na dwa podrzędne rodzaje: zakłady i punkty. Zakłady gastronomiczne są to wyizolowane lokale z salami przeznaczonymi do spożywania posiłków na miejscu, natomiast punkty gastronomiczne znajdują się w kompleksach usługowohandlowych [Brzozowska 2000]. Główny Urząd Statystyczny wyróżnia cztery podstawowe rodzaje placówek gastronomicznych:

- restauracje - zakłady gastronomiczne dostępne dla wszystkich konsumentów, z pełną obsługą kelnerską, oferujące rozmaity wybór dań i napojów;

- bary - placówki, prowadzące działalność zbliżoną do restauracji, o ograniczonym wyborze dań; do tej grupy zaliczamy kawiarnie, bistra, piwiarnie;

- stołówki - placówki, zapewniające posiłki określonej grupie konsumentów;

- punkty gastronomiczne, np. lodziarnie, bufety [GUS 2010].

Widoczny rozwój gastronomii wynika z podwyższenia jakości życia wśród społeczeństwa, wzrostu zamożności, rozwoju turystyki, zmiany diet, popularności, chęci spędzenia czasu poza domem czy możliwości rezygnacji z gotowania w domu i zamówienia potrawy z dowozem [Woźniczko i Orłowski 2020]. Dodatkowo zakłady gastronomiczne stale podwyższają jakość swoich dań i usług, przez co wprowadzają do kart menu coraz więcej dań z różnych kuchni świata [Szymańska-Brałkowska i Zieliński 2012].

Rozrastająca się gastronomia tworzy nowe miejsca pracy, które cieszą się popularnością wśród młodych ludzi rozpoczynających karierę zawodową. Podstawowymi stanowiskami pracy w branży gastronomicznej są kucharze, kelnerzy i barmani. Kelner jest odpowiedzialny za utrzymywanie porządku na salach konsumpcyjnych, dobre samopoczucie klienta, przyjęcie zamówienia na napoje i dania od klienta, przekazanie zamówienia na dania kucharzom, podanie napoi i potraw klientom. Kelner musi znać receptury dań, które są w jadłospisie, a kucharz przygotowuje potrawy według fachowej wiedzy kulinarnej. Zajmuje się „obróbką brudną” żywności związaną m.in. z oczyszczaniem i pozbywaniem części niejadalnych oraz „obróbką czystą” polegającą na rozdrabnianiu żywości, obróbką termiczną i wydaniem potraw. Barmani zajmują się przy-

${ }^{1}$ Uniwersytet Przyrodniczy w Lublinie, Wydział Nauk o Zwierzętach i Biogospodarki, Katedra Higieny Zwierząt i Zagrożeń Środowiska

2 gabskosowska@gmail.com 
gotowywaniem napoi i koktajli, jednakże w dużym stopniu ich obowiązki spoczywają na kelnerach [Nowicki 2010, Trafiałek i in. 2015].

\section{Identyfikacja zagrożeń w środowisku pracy małej gastronomii}

W myśl rozporządzenia w sprawie ogólnych przepisów bezpieczeństwa i higieny pracy, środowiskiem pracy nazywa się warunki środowiska materialnego stanowiska pracy (określonego czynnikami fizycznymi, chemicznymi, biologicznymi), w których odbywa się proces pracy, natomiast zagrożenie oznacza stan środowiska pracy mogący spowodować wypadek lub chorobę. Czynniki te mogą stanowić zagrożenie dla zdrowia i życia pracowników. W związku z tym pracodawca jest zobowiązany zidentyfikować zagrożenia wynikające z charakteru pracy, ocenić ryzyko zawodowe i je udokumentować. Ponadto rozporządzenie zobowiązuje pracodawcę do udostępniania pracownikom oceny ryzyka zawodowego i informowania ich o zagrożeniach wynikających ze stosunku pracy [Dz.U. 1997 poz. 844, Dz.U. 2003 nr 169 poz. 1650]. Identyfikacją zagrożeń nazywamy proces polegający na rozpoznaniu źródeł i charakteru zagrożeń występujących w środowisku pracy [Nowak 2007].

\section{Czynniki biologiczne}

Czynnikami biologicznymi nazywamy drobnoustroje komórkowe również zmodyfikowane genetyczne, jednostki bezkomórkowe zdolne do replikacji lub przenoszenia materiału genetycznego również zmodyfikowane genetycznie, hodowle komórkowe, pasożyty wewnętrzne człowieka, które mogą powodować zakażenia, alergie lub zatrucia. Ryzyko związane jest z występowaniem bakterii, wirusów, grzybów, prionów i pasożytów w środowisku pracy. W załączniku obowiązującego Rozporządzenia, znajduje się wykaz prac narażających pracowników na działanie szkodliwych biologicznych, a praca w zakładach produkujących żywność znajduje się na pierwszym miejscu. Rozporządzenie to nie określa dopuszczalnych stężeń czynników biologicznych w środowisku pracy [Zapór i Kowalska 2010, Dz.U. 2005 nr 81 poz. 716, Dz.U. 2008 nr 48 poz. 288, Dz.U. 2020 poz. 2234].

Ze względu na specyfikę branży gastronomicznej ocena ryzyka zawodowego na czynniki biologiczne nie należy do łatwych. Pracownicy mają styczność zarówno z surowcami roślinnymi, jak i zwierzęcymi. Wiele czynności jest wykonywanych ręcznie, co przy niskim poziomie higieny rąk sprzyja rozwojowi czynników biologicznych oraz zwiększa narażenie na ich działanie. Głównymi źródłami zagrożeń czynnikami biologicznymi są zanieczyszczenia pierwotne i wtórne żywności [Zapór i Gołofit-Szymczak 2009].

Pierwotne zanieczyszczenia żywności stanowią surowce pochodzenia roślinnego i zwierzęcego. Pracownicy są szczególnie narażeni na nie podczas obróbki wstępnej (brudnej i czystej). Produkty roślinne są głównie zanieczyszczone pozostałościami gleby, w której znajdują się liczne mikroorganizmy, takie jak laseczka jadu kiełbasianego mogąca prowadzić do zatrucia śmiertelnego, grzyby pleśniowe czy jaja pasożytów. Surowce zwierzęce natomiast są naturalnym siedliskiem drobnoustrojów, również chorobotwórczych. Mogą wywoływać w różnym nasileniu objawy ze strony układu pokarmowego. Najczęściej choroby w branży gastronomicznej wywołują bakterie rodzaju Salmonella, bakterie Cambylobacter jejuni czy toksyczne szczepy Escherichia coli [Czajkowska i in. 2002, Król i in. 2015]. Przedostawanie się czynników biologicznych do organizmu zachodzi przez: 
- drogi oddechowe - pył organiczny (mąka), kurz, aerozole tworzące się podczas obróbki surowców, bezpośredni kontakt z zarażonym klientem;

- drogi pokarmowe - przeniesienie mikroorganizmów z zanieczyszczonych produktów lub przedmiotów (noże, deski do krojenia, wilki do mielenia mięs zanieczyszczone krwią, odpady żywnościowe), ręce;

- uszkodzoną skórę, błony śluzowe i spojówki;

- zły stan higieny pracowników [Zapór i Gołofit-Szymczak 2009].

Główne zagrożenia dla zdrowia pracownika to:

- działanie alergiczne, wywoływane przez grzyby pleśniowe (Aspergillus spp., A. fumigatus, Penicillium citrinum) oraz promieniowce (Streptomyces spp.);

- lekkie zatrucia pokarmowe wywołane przez bakterie (Bacillus cereus) [Zapór i Kowalska 2010].

Król i in. [2015] wykazały, że poziom świadomości o narażeniu na czynniki biologiczne wśród pracowników zakładów żywienia zbiorowego jest niski. Wskazują one możliwość niedostatecznego informowania pracowników o zagrożeniach występujących na stanowiskach pracy przez pracodawców.

Ponadto przy pracach związanych z przetwórstwem spożywczym występują alergie zawodowe, będące chorobami zawodowymi. Wśród osób narażonych występują zarówno kucharze i kelnerzy. Alergenami dla kucharza mogą być zarówno surowce odzwierzęce, roślinne, przyprawy, barwniki, konserwanty, jak i opakowania produktów żywnościowych czy lateks. Jednak stosunkowo niewiele jest badań prowadzonych w tym zakresie, a dotyczą one głównie środowiska piekarzy [Świderska-Kiełbik i in. 2005].

\section{Czynniki chemiczne}

Czynnikiem chemicznym nazywamy wszystkie związki chemiczne i mieszaniny, w stanie, w jakim występuje w przyrodzie oraz w jakim jest wytwarzany, który jest stosowany lub uwalniany w środowisku pracy, również podczas usuwania odpadów, niezależnie od tego, czy jest wytwarzany celowo lub nie jest wprowadzany do obrotu [Dz.U. $2005 \mathrm{nr} 11$ poz. 86, Dz.U. $2005 \mathrm{nr} 11$ poz. 86].

W odróżnieniu od czynników biologicznych, określone zostały wartości najwyższych dopuszczalnych stężeń (NDS) czynników chemicznych. NDS jest to średnia ważona wartość stężenia, która nie ma negatywnego wpływu na zdrowie pracownika w czasie trwania ośmiogodzinnej zmiany roboczej czy przeciętnego tygodnia pracy, w odniesieniu do okresu aktywności zawodowej pracownika. Pełen ich wykaz znajduje się w Rozporządzeniu Ministra Rodziny, Pracy i Polityki Społecznej z dnia 12 czerwca 2018 r. w sprawie najwyższych dopuszczalnych stężeń i natężeń czynników szkodliwych dla zdrowia w środowisku pracy [Dz.U. 2018 poz. 1286, Dz.U. 2020 poz. 61, Dz.U. 2021 poz. 325].

Pracownicy zakładów gastronomicznych narażeni są na substancje chemiczne nie tylko podczas czynności związanych z przygotowywaniem potraw, ale też podczas czynności porządkowych. Używanie surowych produktów przy obróbce cieplnej skutkuje emitowaniem wielkoskładnikowych par szkodliwych substancji chemicznych do środowiska pracy. Długotrwałe przetwarzanie produktów w wysokich temperaturach sprzyja powstawaniu heterocyklicznych amin aromatycznych (HAA) oraz wielopierścieniowych węglowodorów aromatycznych (WWA) z naturalnych składników surowców. Ich ilość w żywności zależy od sposobu i czasu trwania przygotowywania potrawy. Ponadto w trakcie smażenia i grillowania możliwy jest wyższy poziom stężenia szkodliwego formaldehydu w powietrzu [Kowalska 2009]. Heterocykliczne aminy 
aromatyczne należą do mutagennych i prawdopodobnie rakotwórczych substancji chemicznych, powstających podczas gotowania, smażenia i grillowania produktów o dużej ilości białka, np. mięsa [Majcherczyk i Surówka 2015].

Kucharze narażeni są również na działanie substancji chemicznych celowo dodawanych do żywności, takich jak: wodorowęglan sodu (potocznie nazywany sodą oczyszczoną), chlorek sodu (sól kuchenna), ocet (wodny roztwór kwasu octowego), tłuszcze jadalne czy barwniki spożywcze [Kowalska 2009].

Osoby pracujące w zakładach żywienia zbiorowego są również narażone na różnorodne środki czystości, np. detergenty, w których skład wchodzą związki i substancje chemiczne i ich mieszaniny. Związki te znajdują się w płynach do mycia i płukania naczyń, środkach myjących do grilli i podgrzewaczy, środkach dezynfekujących. W ich składzie można znaleźć żrącą zasadę sodową czy alkohole będące składnikiem płynów do dezynfekcji [Zapór i Kowalska 2011]. Preparaty stosowane do czyszczenia pomieszczeń kuchennych składają się głównie z substancji żrących, mogących powodować oparzenia chemiczne i drażniących, które wpływają na skórę.

\section{Urazy termiczne i skaleczenia}

Jednym z najczęstszych urazów w pracy kucharza są oparzenia termiczne i skaleczenia. Podstawowym wyposażeniem kuchni służącym do obróbki cieplnej są piece, kuchnie gazowe i elektryczne, frytkownice. Stwarzają one realne zagrożenie poparzeniami przy kontakcie z gorącymi urządzeniami, otwartym ogniem czy rozgrzanym tłuszczem i cieczami. Stosowanie noży, tasaków, krajalnic, maszyn do mielenia stwarza narażenie na skaleczenia czy amputacje. Innym narażeniem dla wszystkich pracowników gastronomii jest praca w ciągłym kontakcie $\mathrm{z}$ wodą i wilgocią, co wpływa na warstwę ochronną skóry. Istotnym zagrożeniem jest energia elektryczna, co wynika z obsługi urządzeń kuchennych, gdzie może dojść do porażenia prądem elektrycznym. Pożary w gastronomii występują wskutek niesprawnej instalacji elektrycznej, pozostawienia otwartego i bez nadzoru ognia. Natomiast wybuchy może wywoływać rozszczelnienie butli gazowej przy otwartym ogniu [Kurpiewska $\mathrm{i}$ in. 2013].

\section{Czynniki ergonomiczne i psychospołeczne}

Praca w gastronomii wiąże się z dynamicznym i statycznym obciążeniem fizycznym, co ostatecznie może skutkować przeciążeniami i chorobami układu mięśniowoszkieletowego. Pracownicy tej branży często pracują w pozycji stojącej wymuszonej lub niewygodnej przez większość czasu zmiany roboczej. Pojawiają się wówczas bóle kręgosłupa, kończyn dolnych, mięśni szyi. Kucharze podczas gotowania pochylają głowę, mają wygięte w dół plecy, unoszą ręce powyżej poziomu barków, aby sięgnąc po towar znajdujący się na półkach. Często spotykana w zawodzie kucharza jest też monotypia ruchów podczas krojenia i siekania produktów czy mieszania. Natomiast dostawa towarów wiąże się z przenoszeniem zbiorczych opakowań z żywnością i wówczas może dochodzić do nadmiernego obciążenia układu mięśniowo-szkieletowego [osha.europa.eu/pl/].

Charakterystyczną cechą branży gastronomicznej jest praca zmianowa oraz praca w weekendy i w święta. Personel narażony jest na chroniczny stres zawodowy, który przy braku umiejętnego radzenia sobie z nim może powodować wypalenie zawodowe [Mańkowska 2019]. Chirkowska-Smolak [2009] wymienia jako czynniki wywołujące stres szybkie tempo pracy, wyższe wymagania od pracowników, nadmierne obciążenie 
pracą. Jako objawy wymienia przemęczenie, bóle głowy i bezsenność. Dodatkowym czynnikiem stresogennym w tej branży są wysokie wymagania stawiane przez klientów oraz lek przed popełnieniem błędów.

\section{Mikroklimat}

Mikroklimat to środowisko termiczne na stanowisku pracy, mające wpływ na samopoczucie i wydajność pracownika. Składowymi mikroklimatu są temperatura, wilgotność i ruch powietrza. Mikroklimat zimny charakteryzuje się temperaturą poniżej $10^{\circ} \mathrm{C}$ i powoduje obniżenie temperatury ciała, zwolnienie oddechu, może skutkować zatrzymaniem oddechu i krążenia. Mikroklimat gorący występuje, gdy temperatura powietrza $\mathrm{w}$ miejscu pracy jest wyższa niż $30^{\circ} \mathrm{C}$ - praca $\mathrm{w}$ takich warunkach może skutkować omdleniami, a w skrajnych wypadkach udarami cieplnymi. Mikroklimat umiarkowany jest korzystny dla pracowników, gdyż stwarza odpowiednie warunki pracy [Nowak 2007]. W gastronomii przeważa mikroklimat umiarkowany, a w skrajnych przypadkach - gorący. Dzieje się tak w przypadku niesprawnie działającej wentylacji, co skutkuje wysoką temperaturą pomieszczenia pracy.

\section{Halas}

Hałasem nazywamy każdy niepożądany, nieprzyjemny dźwięk, który może być uciążliwy albo szkodliwy dla zdrowia lub zwiększać ryzyko wypadku przy pracy [Dz.U. $2005 \mathrm{nr} 157$ poz. 1318]. Hałas ma określone najwyższe dopuszczalne natężenie (NDN) w środowisku pracy. Poziom ekspozycji pracownika na hałas odniesiony do 8-godzinnego dobowego wymiaru czasu pracy nie może przekraczać $85 \mathrm{~dB}$, a maksymalny poziom dźwięku nie może przekroczyć 115 dB [Dz.U. 2018 poz. 1286]. Hałas w zależności od poziomu oddziaływania dzielimy na uciążliwy, szkodliwy i niebezpieczny. Poziom jego w granicach 75-80 dB obniża zdolność koncentracji, powoduje zmęczenie; w zakresie 80-120 dB może powodować trwały ubytek słuchu, charakteryzujący się przesunięciem progu słuchu, a powyżej poziomu $130 \mathrm{~dB}$ może powodować natychmiastowe i nieodwracalne uszkodzenie słuchu [Nowak 2007].

W gastronomii hałas emitują urządzenia kuchenne takie jak: wilki do mielenia mięsa, piece, mikrofalówki; sprzęty barowe, np. ciśnieniowy ekspres do kawy, rozmowy klientów i personelu, drukarki drukujące zamówienia, telefony czy zestawy słuchawkowe służące do komunikacji. Muzyka jest również istotnym źródłem hałasu w tym środowisku pracy. Zbyt głośna, powtarzalna może negatywnie wpływać na pracownika, który będzie odbierał ją jako nieprzyjemne dźwięki, co może negatywnie wpływać na wydajność i samopoczucie [Kofin 2012]. Słuchawkowe zestawy komunikacyjne służą do porozumiewania się między pracownikami. Zazwyczaj kelnerzy mają w jednym uchu słuchawkę podłączoną okablowaniem do krótkofalówki. Kucharze nie potrzebują słuchawki, gdyż mówią prosto przez krótkofalówkę. W takiej sytuacji standardowe metody pomiaru hałasu na stanowiskach pracy nie mają zastosowania, wówczas zaleca się inne metody pomiarowe [Pawlaczyk-Łuszczyńska i in. 2020]. 


\section{Cel badań}

Celem badań była ocena narażenia na hałas w czasie ośmiogodzinnego dnia pracy, osoby zatrudnionej na stanowisku kucharza. Pomiary hałasu wykonano w zakładzie małej gastronomii w województwie lubelskim.

\section{Materiał i metody badań}

Badania określające poziom hałasu w zakładzie małej gastronomii przeprowadzono dla pracownika zatrudnionego na stanowisku kucharza $\mathrm{w}$ trakcie zmiany roboczej. Pomiary prowadzono w trakcie następujących czynności: krojenie mięsa i warzyw (1), mielenie mięsa (za pomocą wilka do mięs) (2); obróbka termiczna (gotowanie, smażenie przy kuchni gazowej) (3); wyrób pizzy, pieczenie i grillowanie (4); lepienie pierogów i przygotowywanie szaszłyków (5); zmywanie naczyń (6).

Pomiary wykonano zgodnie z Polską Normą, a dane poddano szczegółowej analizie i przedstawiono na rycinie i w tabeli. Badania prowadzono miernikiem firmy Sonopan klasy 2. W trakcie badań prowadzono kontrolę parametrów mikroklimatycznych w pomieszczeniach pracy. Średnia temperatura wynosiła $18,85^{\circ} \mathrm{C}$, a wilgotność względna $39,03 \%$.

\section{Wyniki badań i ich omówienie}

Badania poziomu hałasu przeprowadzono w trakcie nominalnego dnia pracy kucharza w zakładzie zaliczanym do małej gastronomii. Uzyskane wyniki pomiarów dla różnych czynności oznaczonych od 1 do 6, poddano analizie zgodnie z Polską Normą i zamieszono $\mathrm{w}$ tabeli 1 i na rycinie 1. Najniższy poziom hałasu uzyskano $\mathrm{w}$ trakcie krojenia warzyw i mięs spowodowany uderzeniami noża o deskę do krojenia - 61,8 dB. Natomiast podczas mielenia mięsa gastronomicznym wilkiem uzyskano najwyższy poziom hałasu 73,3 dB. Podczas obróbki termicznej produktów i wyrabiania pizzy, jej pieczenia, a także grillowania uzyskano hałas na poziomie odpowiednio: 66,9 dB i $66,8 \mathrm{~dB}$. Źródłem tych dźwięków były uderzania narzędzi o blat roboczy, grill, a także praca pieca konwekcyjno-parowego.

Pomiary przeprowadzone podczas zmywania naczyń wykazały, iż w trakcie tej czynności średni poziom dźwięku wynosił 71,0 dB. Źródłem tego hałasu były głównie niezamierzone uderzenia metalowymi pojemnikami o metalowy zlew.

Dokładna analiza wszystkich czynności, pozwoliła na określenie poziomu dźwięku w trakcie zmiany roboczej osoby zatrudnionej na stanowisku kucharza (tab. 1). Uwzględniając wszystkie czynności, dzienny poziom ekspozycji kucharza na hałas w tym środowisku wynosi $68,7 \mathrm{~dB}$ i nie przekracza progu działania hałasu oraz najwyższego dopuszczalnego natężenia hałasu w środowisku pracy (NDN $85 \mathrm{~dB}$ ). Natomiast niepewność rozszerzona pomiarów wynosi 1,4 dB. Żychliński i in. [2017] wskazują, iż przy ocenie narażenia na hałas nie można zapomnieć o innych zagrożeniach, które mogą potęgować jego negatywne działanie. Narastanie przewlekłego obrazu akustycznego mogą zwiększać obecne w środowisku związki chemiczne, takie jak rozpuszczalniki organiczne, metale ciężkie czy niektóre pestycydy. 
Tabela 1. Dzienny poziom ekspozycji na hałas w odniesieniu do poszczególnych czynności (ISO 9612)

\begin{tabular}{|l|c|c|c|c|c|c|}
\hline \multirow{2}{*}{ Parametry } & \multicolumn{7}{|c|}{ Wyodrębnione czynności } \\
\cline { 2 - 7 } & 1 & 2 & 3 & 4 & 5 & 6 \\
\hline Średni poziom hałasu $(\mathrm{dB}) \mathrm{L}_{\mathrm{p}, \mathrm{A}, \mathrm{eq} \mathrm{T}, \mathrm{m}}$ & 61,8 & 73,3 & 66,9 & 66,8 & 68,5 & 71,0 \\
\hline Średni czas trwania $(\mathrm{h}) \mathrm{Tm}$ & 1,0 & 0,8 & 1,2 & 2,0 & 2,3 & 0,7 \\
\hline Udział czynności w Lex,8 h & 52,8 & 63,3 & 58,6 & 60,8 & 63,1 & 60,5 \\
\hline Suma dla wszystkich czynności u ${ }^{2}\left(\mathrm{~L}_{\mathrm{EX}, 8 \mathrm{~h}}\right)=0,73$ \\
\hline Złożona niepewność standardowa $\mathrm{u}\left(\mathrm{L}_{\mathrm{EX}, 8 \mathrm{~h}}\right)=0,9 \mathrm{~dB}$ & \multicolumn{2}{|l}{ Niepewność rozszerzona } \\
\hline Dzienny poziom ekspozycji na hałas $\mathrm{L}_{\mathrm{EX}, 8 \mathrm{~h}}=68,7 \mathrm{~dB}$ & $\mathrm{U}\left(\mathrm{L}_{\mathrm{EX}, 8 \mathrm{~h}}\right)=1,65 * \mathrm{u}\left(\mathrm{L}_{\mathrm{EX}, 8 \mathrm{~h}}\right)=1,4$ \\
\hline
\end{tabular}

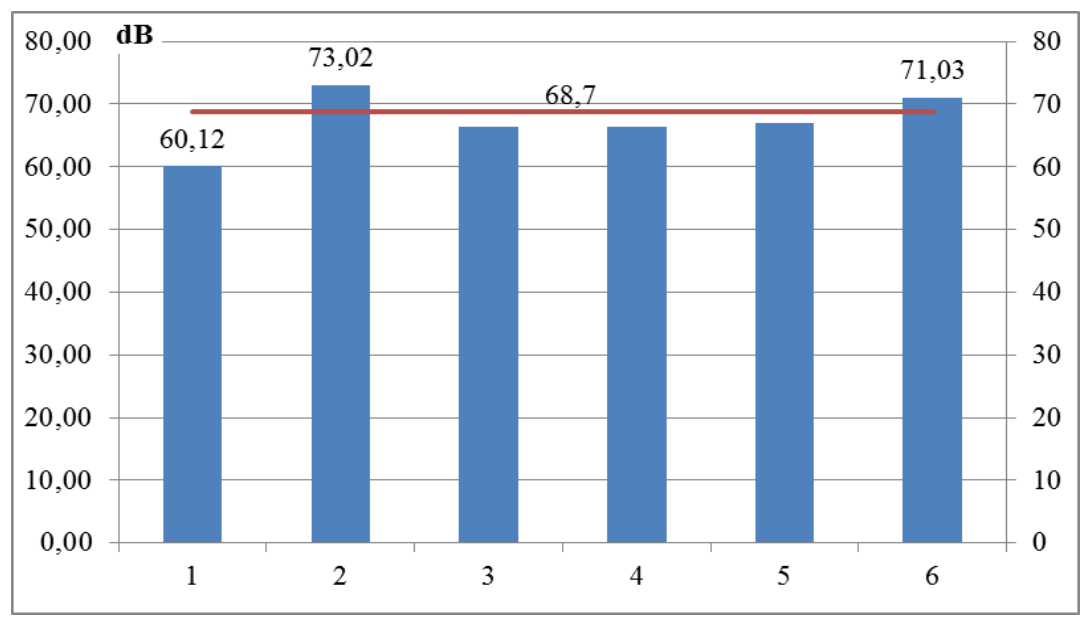

Ryc. 1. Poziom hałasu dla poszczególnych czynności na tle dziennego poziomu ekspozycji (dB)

Innym istotnym zagrożeniem pojawiającym się w tej branży jest praca rąk w mokrym środowisku z płynami wykazującymi właściwości drażniące. Kieć-Świerczyńska $\mathrm{i}$ in. [2010] zaliczają taka pracę do tzw. mokrego środowiska pracy. Wykonywanie pracy przy długotrwałym kontakcie z wodą może prowadzić do zmian w strukturze i funkcji skóry. Dlatego zaleca się stosowanie rękawic ochronnych, niemniej jednak ostateczna decyzja powinna być konsultowana $\mathrm{z}$ pracownikami, aby nie pojawiły się inne uboczne efekty ich stosowania.

\section{Podsumowanie}

Praca $\mathrm{w}$ gastronomii, w szczególności na stanowisku kucharza, wiąże się z wieloma zagrożeniami, których następstwa działania mogą przejawiać się skaleczeniami, alergiami, oparzeniami itp. Analiza wyników poziomu dźwięku w tym środowisku wykazała, iż nie stanowi on zagrożenia dla kucharza. Stwierdzono, iż hałas nie jest czynnikiem szkodliwym na tym stanowisku i nie powoduje negatywnych skutków dla zdrowia pracowników. 


\section{Bibliografia}

Brzozowska W., 2000. Usługi cateringowe. WSM, Warszawa.

Chirkowska-Smolak T., 2009. Organizacyjne czynniki wypalenia zawodowego. Ruch Prawniczy, Ekonomiczny i Socjologiczny, LXXI, 4, 257-272.

Czajkowska D., Sikorska I., Witkowska-Gwiazdowska A., 2002. Problemy w wykrywaniu bakterii Salmonella w żywności. Przemysł Spoż. 56 (9), 2-6.

Europejska Agencja Bezpieczeństwa i Zdrowia w Pracy. Choroby układu mięśniowo-szkieletowego (MSD) w sektorze Horeca. https://osha.europa.eu/pl/publications/e-fact-24-musculoskeletaldisorders-msds-horeca [dostęp 23.03.21]

GUS, 2010. Rynek Wewnętrzny 2009, Warszawa, https://stat.gov.pl/metainformacje/slownikpojec/pojecia-stosowane-w-statystyce-publicznej/300,poje-cie.html [dostęp 22.02.21]

Kieć-Świerczyńska M., Chomiczewska D., Kręcisz B., 2010. Wet work - praca w środowisku mokrym. Med. Pracy 61 (1), 65-77.

Kofin E., 2012. Muzyka jako hałas. Prace Kulturozn. 13. 71-77

Kowalska J., 2009. Szkodliwe czynniki chemiczne w placówkach gastronomicznych. Bezpieczeństwo Pracy: Nauka i Praktyka 5, 14-16,

Król J., Litwińczuk A., Rękas M., 2015. Stan wiedzy pracowników zakładów zbiorowego żywienia o narażeniu na czynniki biologiczne. Funkcjonowanie i Doskonalenie Zarządzania Aspekty Społeczne, 76-91.

Kurpiewska J., Liwkowicz J., Padlewska K., 2013. Profilaktyka dermatoz rąk w małych zakładach gastronomicznych. Med. Pracy, 64(4), 521-525. http://dx.doi.org/10.13075/mp.5893.2013.0047

Majcherczyk J., Surówka K., 2015. Heterocykliczne aminy aromatyczne jako zagrożenie chemiczne w produktach mięsnych poddawanych obróbce termicznej. Żywność. Nauka. Technologia. Jakość, 1 (98), 16-34. doi: 10.15193/zntj/2015/98/002

Mańkowska B., 2019. Stresogenność warunków pracy oraz radzenie sobie ze stresem a wypalenie zawodowe wśród pracowników gastronomii. Polskie Forum Psychol. 24, 4, 400-418. doi: 10.14656/PFP20190402

Nowak P., 2007.Technik bezpieczeństwa i higieny pracy: Identyfikowanie czynników środowiska pracy. 8, ITE-PIB, Radom.

Nowicki P., 2010. Wymagania i wdrażanie zasad GMP i GHP w zakładach żywienia zbiorowego Zesz. Nauk. 815 Uniw. Ekon. w Krakowie.

Obwieszczenie Ministra Gospodarki, Pracy i Polityki Społecznej z dnia 28 sierpnia 2003 r. w sprawie ogłoszenia jednolitego tekstu rozporządzenia Ministra Pracy i Polityki Socjalnej w sprawie ogólnych przepisów bezpieczeństwa i higieny pracy [Dz.U. $2003 \mathrm{nr} 169$ poz. 1650].

Pawlaczyk-Łuszczyńska M., Dudarewicz A., Zamojska-Daniszewska M., Zaborowski K., 2020. Wytyczne dotyczące zasad kontroli narażenia na hałas i minimalizowania jego niekorzystnych skutków u pracowników stosujących słuchawkowe zestawy komunikacyjne. Łódź.

Rozporządzenie Ministra Gospodarki i Pracy z dnia 5 sierpnia 2005 r. w sprawie bezpieczeństwa i higieny pracy przy pracach związanych $\mathrm{z}$ narażeniem na hałas lub drgania mechaniczne [Dz.U. $2005 \mathrm{nr} 157$ poz. 1318].

Rozporządzenie Ministra Rodziny, Pracy i Polityki Społecznej z dnia 9 stycznia 2020 r. zmieniające rozporządzenie w sprawie najwyższych dopuszczalnych stężeń i natężeń czynników szkodliwych dla zdrowia w środowisku pracy [Dz.U. 2020 poz. 61].

Rozporządzenie Ministra Rozwoju, Pracy i Technologii z dnia 18 lutego 2021 r. zmieniające rozporządzenie w sprawie najwyższych dopuszczalnych stężeń i natężeń czynników szkodliwych dla zdrowia w środowisku pracy [Dz.U. 2021 poz. 325].

Rozporządzenie Ministra Zdrowia z dnia 11 grudnia 2020 r. zmieniające rozporządzenie w sprawie szkodliwych czynników biologicznych dla zdrowia w środowisku pracy oraz ochrony zdrowia pracowników zawodowo narażonych na te czynniki [Dz.U. 2020 poz. 2234].

Rozporządzenie Ministra Zdrowia z dnia 22 kwietnia 2005 r. w sprawie szkodliwych czynników biologicznych dla zdrowia w środowisku pracy oraz ochrony zdrowia pracowników zawodowo narażonych na te czynniki [Dz.U. $2005 \mathrm{nr} 81$ poz. 716]. 
Rozporządzenie Ministra Zdrowia z dnia 29 lutego 2008 r. zmieniające rozporządzenie w sprawie szkodliwych czynników biologicznych dla zdrowia w środowisku pracy oraz ochrony zdrowia pracowników zawodowo narażonych na te czynniki [Dz.U. $2008 \mathrm{nr} 48$ poz. 288].

Rozporządzenie Ministra Zdrowia z dnia 30 grudnia 2004 r. w sprawie bezpieczeństwa i higieny pracy związanej z występowaniem w miejscu pracy czynników chemicznych [Dz.U. $2005 \mathrm{nr} 11$ poz. 86].

Rozporządzeniu Ministra Rodziny, Pracy i Polityki Społecznej z dnia 12 czerwca 2018 r. w sprawie najwyższych dopuszczalnych stężeń i natężeń czynników szkodliwych dla zdrowia w środowisku pracy [Dz.U. 2018 poz. 1286].

Szymańska-Brałkowska M., Zieliński G., 2012. Zielone linie jako doskonalenie jakości usług gastronomicznych z uwzględnieniem orientacji na klienta. Zarządzanie i Finanse 10 (3), 76-87.

Świderska-Kiełbik S., Krakowiak A., Wittczak T., Pałczyński C., 2005. Alergia zawodowa istotne zagrożenie zdrowia pracowników przemysłu spożywczego. Med. Pracy 56 (6), 475-483.

Trafiałek J., Czarniecka-Skubina E., Kołożyn-Krajewska D., Pałubicki B., Makuszewska K., 2015. Higiena w zakładach gastronomicznych wytwarzających żywność w obecności konsumenta. Żywność. Nauka. Technologia. Jakość, 2 (99), 208-221. doi: 10.15193/zntj/2015/99/034

Woźniczko M., Orłowski D., 2020. Analiza i ocena rozwoju rynku gastronomicznego w Polsce na początku XXI wieku, 48-63.

Zapór L., Gołofit-Szymczak M., 2009. Zagrożenia biologiczne w placówkach gastronomicznych. Bezpieczeństwo pracy: Nauka i Praktyka 2, 6-9.

Zapór L., Kowalska J., 2011. Ocena narażenia na czynniki biologiczne i chemiczne w małych zakładach gastronomicznych. Bezpieczeństwo Pracy: Nauka i Praktyka 5, 12-15.

Zapór L., Kowalska J., 2010. Zagrożenia biologiczne i chemiczne w małych zakładach gastronomicznych, wyd. CIOP-PIB, 14-16.

Żychliński M., Siermontowski P., Olszańsi R, 2017. Ocena warunków sanitarno-epidemiologicznych służby na okręcie podwodnym. Polish Hyperbaric Res. 1(58), 51-62. 
Gabriela Kosowska $^{1,3}$, Bożena Nowakowicz-Dębek ${ }^{1}$, Lukasz Wlazło ${ }^{1}$, Martyna Kasela ${ }^{2}$, Mateusz Ossowski ${ }^{1}$

\section{Zagrożenia chemiczne w trakcie pracy kosmetyczki}

Chemical hazards during the work of the beautician

Na rynku usług kosmetycznych w Polsce funkcjonuje kilkadziesiąt tysięcy różnorodnych salonów kosmetycznych, a ich liczba wzrasta, zwłaszcza w postaci nowych systemów franczyzowych. W roku 2019 stanowiły one 92683 podmiotów gospodarczych. Dokładna analiza rynku branży kosmetycznej jest utrudniona, gdyż istnieje problem z pozyskaniem dokładnych danych, co wynika z klasyfikacji usług, według obowiązującej definicji salonu usług kosmetycznych. PKD dla tej kategorii działalności oznaczono numerem 96.02.Z i obejmuje: Fryzjerstwo i pozostałe zabiegi kosmetyczne [Raport 2012].

Narastające w ostatnich latach zainteresowanie zabiegami z zakresu kosmetyki pielęgnacyjnej czy stylizacji i wizażu wpływa na wzrost liczby usług świadczonych przez gabinety kosmetyczne. Zainteresowanie nowymi technikami modelowania paznokci wpływa na wzrost liczby salonów, które oferują takie usługi, co wymusza konieczność podnoszenia kwalifikacji pracowników.

Ze względu na trwającą epidemię SARS-CoV-2, pracownicy Ministerstwa Rozwoju, Pracy i Technologii z Głównym Inspektoratem Sanitarnym opracowali wytyczne dla gabinetów świadczących usługi kosmetyczne i estetyczne [https:/www.gov.pl/web/rozwojpraca-technologia/salony-kosmetyczne; Informacja o zawodzie 2018]. Praca kosmetyczkimanicurzystki realizowana jest $\mathrm{w}$ formie usług osobistych zgodnie $\mathrm{z}$ posiadaną wiedzą, umiejętnościami i doświadczeniem. Manicure najczęściej obok typowej pielęgnacji obejmuje wykonanie ciekawego i estetycznego, a często oryginalnego wzoru z wykorzystaniem różnych substancji chemicznych, w tym akrylanów czy rozpuszczalników. Stąd narażenie pracowników salonów kosmetycznych na wdychanie uwalnianych chemicznych zanieczyszczeń. W zależności od wykorzystywanych lakierów, zmywaczy czy samej techniki realizacji manicure występuje narażenie pracowników na uwalniane zanieczyszczenia gazowe. Zgodnie z obowiązującymi regulacjami prawnymi, ,pracodawca jest zobowiązany do ustalenia, jakie czynniki chemiczne stwarzające zagrożenie występują w środowisku pracy" [Informacja o zawodzie 2018; Raport 2012; Dz.U. 2005 nr 11 poz. 86 z późn. zm.]. Pracownik zakładu kosmetycznego w trakcie wykonywania swojej pracy narażony jest nie tylko na czynniki biologiczne, fizyczne, pschospołeczne, wynikające $\mathrm{z}$ organizacji pracy, ale również na niebezpieczne substancje chemiczne, które mogą powodować egzemy, choroby układu oddechowego, a także reakcje alergiczne.

${ }^{1}$ Uniwersytet Przyrodniczy w Lublinie, Wydział Nauk o Zwierzętach i Biogospodarki, Katedra Higieny Zwierząt i Zagrożeń Środowiska

${ }^{2}$ Uniwersytet Medyczny w Lublinie, Katedra i Zakład Mikrobiologii Farmaceutycznej

3 gabskosowska@gmail.com 
Reakcja układu oddechowego zależy od nasilenia działania czynnika alergizującego, który prowadzi do pobudzenia układu immunologicznego [Szewczyńska i in. 2010].

Wykonywanie zawodu kosmetyczki-manicurzystki wymaga podstawowej wiedzy nie tylko branżowej, a także z zakresu chorób cywilizacyjnych czy obecności zagrożeń w środowisku pracy, co pozwoli na odpowiednie zastosowanie środków ochrony indywidualnej. Zgodnie z Rozporządzeniem Ministra Zdrowia w sprawie bezpieczeństwa i higieny pracy związanej z występowaniem w miejscu pracy czynników chemicznych, należy określić występowanie czynnika chemicznego stwarzającego zagrożenie, określić narażenie pracownika oraz przeprowadzić ocenę ryzyka zawodowego stwarzanego przez ten czynnik. Dlatego przeprowadzono badania, których celem było monitorowanie zagrożeń chemicznych w trakcie wykonywania zabiegów manicure.

\section{Materiał i metody badań}

Na potrzeby doświadczenia przygotowano zestaw lakierów (7) oraz 2 zmywaczy wykorzystywanych w typowym gabinecie kosmetycznym. Modelowe uwalnianie substancji chemicznych z badanych kosmetyków monitorowano w laboratorium Katedry Higieny Zwierząt i Środowiska. Pomiary obejmowały wielkość uwalnianych substancji z wykorzystywanych lakierów oraz stosowanych zmywaczy do paznokci. Wśród lakierów objętych badaniami uwzględniono lakiery klasyczne, hybrydowe oraz szybkoschnące, natomiast wśród zmywaczy bezacetonowe oraz zawierające aceton. Pomiar uwalnianych zanieczyszczeń przeprowadzono korzystając ze stacji pomiarowej wyposażonej w czujniki $\mathrm{NH}_{3}, \mathrm{H}_{2} \mathrm{~S}$ i PID.

Zmywacz do paznokci na bazie acetonu (1), przeznaczony do lakieru hybrydowego, w swoim składzie obok acetonu zawiera glicerynę, ekstrakty zapachowe, alkohole, glicerynę $\mathrm{i}$ in. Według danych producenta pielęgnuje płytkę, nadając jej piękny połysk. Zmywacz acetonowy według producenta zawiera również ekstrakty zapachowe, a oprócz usuwania lakieru, utwardza paznokcie. Zmywacz bezacetonowy (2) - to mieszanina olejków zapachowych oraz octanu etylu i alkoholu izopropylowego. W karcie charakterystyki substancji zamieszczono informacje, że ich pary mogą wywoływać uczucie senności i zawroty głowy, podrażnienie i zaczerwienienie skóry, a przypadku kontaktu z oczami może prowadzić do ich podrażnienia i pieczenia.

Wśród lakierów klasycznych objętych badaniami numerem 1 oznaczono lakier, będący mieszaniną substancji organicznych, zwierający m.in. octany i ksylen oraz substancje pomocnicze. W karcie charakterystyki zamieszczono informacje, że działa drażniąco na skórę, oczy i może wywołać uczucie senności, a nawet zawroty głowy (według 1907/2006/WE (REACH), 2015/830/EU).

Natomiast uwzględnione w badaniach lakiery szybkoschnące (2) zawierają głównie mieszaninę octanów, alkoholi, nitrocelulozę, glikol, kopolimer, akrylan i inne.

Lakiery hybrydowe, czyli produkty światłoutwardzalne (3) według karty charakterystyki w swoim składzie zawierają m.in.: kwas metakrylowy, monoester z propan-1,2-diolem; metakrylan 2-hydroksyetylu (według 1907/2006/WE (REACH), 453/2010/WE). Producent podaje, iż działa drażniąco na skórę, oczy i może wywoływać reakcję alergiczną. Niestety nie dla wszystkich lakierów udało się pozyskać karty charakterystyki.

Przed przystąpieniem do badań uruchomiono stację pomiarową, aby oszacować stężenie zanieczyszczeń $\mathrm{w}$ powietrzu przed czynnościami $\mathrm{z}$ wykorzystaniem lakierów i zmywaczy do paznokci. Następnie, korzystając z poszczególnych lakierów i zmywaczy, 
wykonywano pomiary dla typowych czynności, jakie wykonywane są w gabinecie kosmetycznym. Wyniki pomiarów po opracowaniu przedstawiono $\mathrm{w}$ tabelach i na rycinach.

\section{Wyniki i ich omówienie}

W trakcie prowadzonych badań koncentracja amoniaku i siarkowodoru nie stanowiła istotnego zagrożenia. Stężenie amoniaku w trakcie pracy ze zmywaczami przybierało wartości od 0,003 do 0,006 ppm, siarkowodoru 0,018 ppm, a PID od 10,357 do 12,280 ppm (tab. 1). W trakcie pracy z lakierami koncentracja amoniaku i siarkowodoru była na bardzo niskim poziomie i wynosiła odpowiednio: 0,003-0,011 ppm i 0,003-0,054 ppm. Natomiast stężenie PID w tym czasie wahało się od 7,610 do 208,754 ppm. Najwyższe wartości PID uzyskano dla lakierów szybkoschnących (ryc. 1). W trakcie wietrzenia pomieszczenia stężenie tych zanieczyszczeń uległo obniżeniu do $2,848 \mathrm{ppm}$. Średni poziom substancji w trakcie badań wynosił 0,008 ppm $\left(\mathrm{NH}_{3}\right), 0,024$ ppm $\left(\mathrm{H}_{2} \mathrm{~S}\right)$ i 52,123 ppm (PID).

Tabela 1. Koncentracja substancji gazowych w powietrzu w trakcie wykorzystywania kosmetyków (ppm)

\begin{tabular}{|l|c|c|c|}
\hline \multicolumn{1}{|c|}{ Produkt } & $\mathrm{NH}_{3}$ & $\mathrm{H}_{2} \mathrm{~S}$ & PID \\
\hline Zmywacz 1 & 0,006 & 0,018 & 10,357 \\
Zmywacz 2 & 0,003 & 0,018 & 12,280 \\
Lakier 1 & 0,003 & 0,029 & 11,369 \\
Lakier 2 & 0,010 & 0,050 & 32,354 \\
Lakier 3 & 0,009 & 0,003 & 35,300 \\
Lakier 4 & 0,010 & 0,014 & 94,060 \\
Lakier 5 & 0,009 & 0,012 & 106,300 \\
Lakier 6 & 0,009 & 0,016 & 208,754 \\
Lakier 7 & 0,011 & 0,054 & 7,610 \\
Wietrzenie pomieszczenia & 0,010 & 0,027 & 2,848 \\
M & 0,008 & 0,024 & 52,123 \\
SD & 0,003 & 0,016 & 66,083 \\
\hline
\end{tabular}

$\mathrm{M}$ - średnia arytmetyczna; SD - odchylenie standardowe

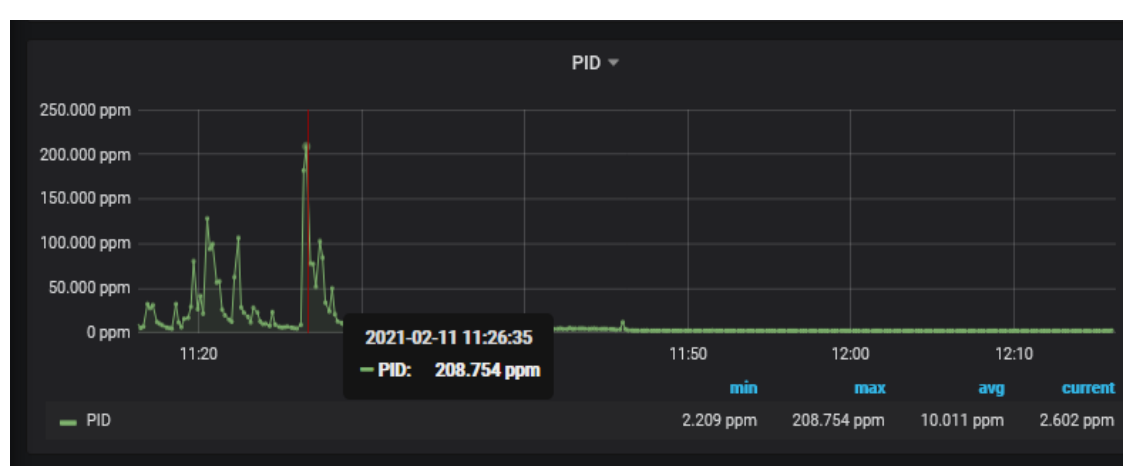

Ryc. 1. Pomiar PID w trakcie korzystania z lakieru szybkoschnącego 
Dotychczas często wśród wymienianych zagrożeń w środowisku pracy kosmetyczek i podologów dużą uwagę zwraca się na szkodliwe czynniki biologiczne (SCB) oraz pył, który tworzą swoisty dla tego środowiska bioaerozol. Wdychanie jednak w miejscu pracy substancji określanych jako działające drażniąco czy uczulająco na drogi oddechowe może prowadzić do powstania astmy zawodowej. Badania ankietowe prowadzone dla tej branży wykazały, iż prawie $40 \%$ respondentów ma problemy na tle alergicznym, ponad $50 \%$ wskazuje na częste podrażnienia oczu. Przeważająca część ankietowanych wie, że te zagrożenia powstają właśnie w trakcie czyszczenia mechanicznego paznokci [Millar 2000, Burrow i McLarnon 2006]. Niewiele jest informacji o zagrożeniach stwarzanych przez substancje chemiczne wykorzystywane w tej branży. Być może jest to związane z tym, że skutki narażenia nie zawsze pojawiają się bezpośrednio po ekspozycji, tylko w czasie wolnym od pracy [Szewczyńska i in. 2011]. Rozwój przemysłu, w tym również chemicznego, wprowadził do branży kosmetycznej wiele nowych substancji/mieszanin. Obowiązujące przepisy prawne obligują producentów do tworzenia kart charakterystyki dla produkowanych substancji. Zawierają one informacje o narażeniu i skutkach, jakie one niosą, podstawowe dane fizykochemiczne, a także zalecane środki ochrony zbiorowej lub indywidualnej. Wzrost zagrożeń stwarzanych przez pojawiające się substancje chemiczne, a z drugiej strony koszty ekonomiczne, jakie wiążą się z działaniami profilaktycznymi, w świetle obowiązujących przepisów wymusza identyfikowanie wszystkich zagrożeń w środowisku pracy [Pośniak 2005, Dz.U. $2005 \mathrm{nr} 11$ poz. 86 z późn. zm].

Producenci zmywaczy do paznokci i lakierów wskazują, iż przy wykorzystywaniu niniejszych substancji należy stosować środki ochrony oczu lub twarzy, np. odpowiednie okulary ochronne. Do ochrony rąk zaleca się rękawice ochronne, np. z kauczuku butylowego. Przy ochronie skóry można również zastosować fartuch ochronny, najlepiej antyelektrostatyczny. Natomiast w celu ochrony dróg oddechowych wskazane jest stosowanie odpowiedniej wentylacji $\mathrm{w}$ celu zapobiegania przekraczania najwyższego dopuszczalnego stężenia (NDS) ze stosowanych lakierów czy zmywaczy. W zakładach kosmetycznych, gdzie prowadzono wywiad w zakresie stosowania lakierów do paznokci i zmywaczy, nie uzyskano jednoznacznych odpowiedzi, co do ochrony oczu i dróg oddechowych. Najczęściej z grupy są stosowane jednorazowe rękawice lateksowe lub nitrylowe. Badania własne wskazują na konieczność stosowania ochron dróg oddechowych, ze względu na wysokie poziomy detekcji lotnych związków organicznych, które okresie narażenia zawodowego mogą prowadzić do nieodwracalnych zmian w układzie oddechowym pracowników tej branży.

Dotychczas prowadzone badania przez CIOP dla tej branży skupiały się na skuteczności ochrony skóry, poprzez właściwy dobór środków profilaktycznych. Zawód kosmetyczki jest uważany za tzw. mokry zawód, co wynika z definicji, że pracownik ponad 2 godziny trzyma ręce w ,środowisku mokrym" lub nosi rękawice ochronne [European Agency for Safety and Health at Work 2008, Kurpiewska i in. 2011, Kurpiewska i Liwkowicz 2013]. Właściwy dobór ŚOI jest istotny z punktu widzenia chorób zawodowych takich jak: kontaktowe zapalenie skóry, pokrzywka kontaktowa, drożdżakowe zapalenie skóry, grzybice skóry. Jako najczęściej drażniące czynniki w tym zawodzie wymienia się: mydła, zasady, kwasy, emulsje, rozpuszczalniki organiczne czy związki nieorganiczne itp. [Starzyk i Gwardys 2008, Kieć-Świerczyńska i in. 2013, Kurpiewska i Liwkowicz 2013]. Badania prowadzone przez ten zespół potwierdziły częste występowanie zmian skórnych u kosmetyczek, stąd konieczność wdrożenia ochrony. Prawie połowa badanych stwierdziła, że ich dłonie są przesuszone, a po 30 dniach stosowa- 
nia odpowiednio dostosowanego preparatu 90\% odnotowało wyraźną poprawę skóry rąk [Kurpiewska i Liwkowicz 2013]. Autorzy wskazują, iż adeptki tego zawodu należy informować o szkodliwości substancji występujących w pracy zawodowej i możliwości wykorzystania wodoodpornych preparatów barierowych pełniących istotną funkcję ochronną. Wielu autorów [Kwapniewski i in. 2008, Quach i in. 2010, Kieć-Świerczyńska i in. 2013] wskazuje, że produkty wykorzystywane w trakcie zabiegów kosmetycznych mogą zawierać w swoim składzie substancje kancerogenne, jak formaldehyd, tlenek tytanu. Natomiast kosmetyki zwierające parabeny czy aceton mogą wpływać na rozwój hormonozależnych nowotworów. Stąd konieczne jest uświadamianie pracowników tej branży o konieczności kontroli warunków mikroklimatycznych w salonach, a zwłaszcza działających systemów wentylacyjnych.

Istotne zagrożenie dla tej branży stanowią również kosmetyki nowej generacji, zawierające substancje endokrynnie aktywne EDCs (ang. endocrine disrupting chemical) [Gromadzińska i in. 2019]. Występują one w mydłach w płynie, lakierach do paznokci, lakierach do włosów, filtrach przeciwsłonecznych i wielu innych kosmetykach. W tym środowisku zawodowym EDCs mogą występować w postaci gazów, kropli cieczy lub cząstek stałych. Główną drogą narażenia zawodowego jest układ oddechowy i skóra, a skutki zależą m.in. od miejsca osadzania się w drogach oddechowych, ich wielkości czy obecności innych substancji. Cząstki zaliczane do frakcji respirabilnej stanowią największe zagrożenie dla pracowników. Duże zainteresowanie nie tylko w tej branży występuje dla EDCs ze względu na regulację metabolizmu poprzez hormony płciowe. Dlatego zaleca się pomiar biomarkerów, co pozwoli na określenie rzeczywistej wielkości narażenia pracowników [Gromadzińska i in. 2019].

$\mathrm{Z}$ informacji zamieszczanych w kartach charakterystyki wykorzystywanych preparatów w tym zmywaczy do paznokci, które są kompatybilne z rozporządzeniem dotyczącym kontroli narażenia zawodowego wynika, że konieczne jest prowadzenie szkoleń dla branży kosmetycznej w zakresie doboru odpowiednich środków profilaktycznych, aby poprawić bezpieczeństwo tych pracowników.

\section{Podsumowanie}

Wykorzystane lakiery oraz kosmetyki o dużej lotności mogą stanowić nowe zagrożenie dla pracowników i klientów branży kosmetologicznej. Ze względu na dużą intensywność parowania szybkoschnących substancji chemicznych oraz wykorzystywane promieniowanie UV do suszenia i utwardzania lakierów należy przeprowadzić monitoring środowiska pracy w tym zakresie, aby skutecznie identyfikować i przeciwdziałać szkodliwym skutkom ich coraz powszechniejszego wykorzystywania.

\section{Bibliografia}

Burrow J.G., McLarnon N.A., 2006. World at work: Evidence based risk management of nail dust in chiropodists and podiatrists. Occup. Environ. Med. 63(10), 713-716. DOI: 10.1136/oem.2006.027565.

European Agency for Safety and Health at Work (2008), European Risk Observatory report: Occupational skin diseases and dermal exposure in the EU (EU-25): http://osha.europa.eu/en/publications/reports/TE7007049ENC_skin_diseases. 
Gromadzińska J., Szewczyńska M., Pośniak M., Wiszniewska M., 2019. Narażenie zawodowe na substancje endokrynnie aktywne. Materiał szkoleniowy. Inst. Med. Pracy im. prof. dr J. Nofera, Łódź, Warszawa.

https://www.gov.p1/web/rozwoj-praca-technologia/salony-kosmetyczne.

Informacja o zawodzie. Kosmetyczka. Ministerstwo Rodziny, Pracy i Polityki Społecznej, Departament Rynku Pracy, Warszawa 2018.

Karta charakterystyki według 1907/2006/WE (REACH), 2015/830/EU.

Karta charakterystyki według 1907/2006/WE (REACH), 453/2010/WE.

Kieć-Świerczyńska M., Chomiczewska-Skóra D., Świerczyńska-Machura D., Kręcisz B., 2013. Manikiurzystki i pedikiurzystki jako grupa zawodowa o istotnym ryzyku dermatoz związanych z pracą. Med. Pracy, 64(4), 579-591.

Kurpiewska J., Liwkowicz J., Benczek K., Padlewska P.A., 2011. Survey of work-related skin diseases in different occupations in Poland. Int. J. Occup. Saf. Ergon. 17, 2, 207-214

Kurpiewska J., Liwkowicz J., 2013. Skuteczność środków ochrony skóry stosowanych przez kosmetyczki - badania ankietowe i dermatologiczne. Bezpieczeństwo Pracy 2, 13-16.

Kwapniewski R., Kozaczka S., Hauser R., Silva M.J., Calafat A.M., Duty S.M., 2008. Occupational exposure to dibutyl phthalate among manicurists. J. Occup. Environ. Med. 50(6), 705-711, http://dx.doi.org/10.1097/JOM.0b013e3181651571

Millar N.A., 2000.The ocular risks of human nail dust in podiatry. PhD Thesis, Glasgow Caledonian Univ.

Pośniak M., 2005. Ocena ryzyka zawodowego - narażenie na czynniki chemiczne (1), Bezpieczeństwo Pracy 7-8, 408-409.

Quach T., Doan-Billing P.A., Layefsky M., Nelson D., Nguyen K.D., Okahara L., Tran A.N., Von Behren J., Reynolds P., 2010. Cancer incidence in female cosmetologists and manicurists in California, 1988-2005. Am. J. Epidemiol. 172(6), 691-699, http://dx.doi.org/10.1093/aje/kwq190

Raport. 2012. Rynek usług kosmetycznych w Polsce. Trendy, kierunki rozwoju, strategie i metody działania. Questus, Warszawa/Łódź.

Rozporządzenie Ministra Zdrowia z dnia 30 grudnia 2004 r. w sprawie bezpieczeństwa i higieny pracy związanej z występowaniem w miejscu pracy czynników chemicznych (Dz.U. $2005 \mathrm{nr} 11$ poz. 86 z późn. zm.).

Starzyk E., Gwardys A., 2008. Lakiery do paznokci - co dozwolone, co zakazane? Wiad. Kosmet. 3(21), 28-30.

Szewczyńska M., Dobrzyńska E., Pośniak M., Jeżewska A., 2011. Czynniki chemiczne w zakładach fryzjerskich - zagrożenia i profilaktyka. Bezpieczeństwo Pracy 1, 14-17.

Szewczyńska M., Gołofit-Szymczak M., Roman-Liu D., Mikulski W., 2010. Zagrożenia czynnikami chemicznymi, biologicznymi, biomechanicznymi i hałasem w małych zakładach fryzjersko-kosmetycznych. CIOP-PIB, Warszawa. 
Bartłomiej Mistal $^{1,3}$, Anna Pecyna (D) ${ }^{2}$, Agnieszka Buczaj (D)², Dżesika Stankiewicz ${ }^{1}$

\title{
Organizacja ochrony przeciwpożarowej i zabezpieczenie przeciwpożarowe na przykładzie domu pomocy społecznej
}

\author{
Organization of fire protection and prevention from fire risks based \\ on Social Care Center
}

\begin{abstract}
Niniejszy artykuł przedstawia wykorzystanie autorskiej listy kontrolnej w celu kontroli warunków bezpieczeństwa pożarowego w jednym z domów pomocy społecznej. Zagadnienie to jest jednym z elementów ochrony przeciwpożarowej, którą w świetle prawa definiuje się jako działania mające na celu zapobieganie powstawania oraz rozprzestrzeniania się pożaru i innych klęsk żywiołowych. Ponadto ochrona przeciwpożarowa zajmuje się także zapewnianiem środków i sił do zwalczania tych zagrożeń oraz prowadzeniem akcji ratowniczych. Działania te służą ochronie życia, zdrowia i mienia ludzkiego oraz środowiska [Dz.U. z 2020 poz. 961].

Bezpieczeństwo polega na subiektywnym odczuwaniu przez jednostkę braku zagrożenia [Korzeniowski 2000]. Pewne sytuacje mogą wywołać więc u każdego inne reakcje. Dla zapewnienia prawidłowego funkcjonowania człowieka konieczne jest poczucie bezpieczeństwa, które funkcjonuje na wielu płaszczyznach życia. Człowiek ma potrzebę czucia się bezpiecznie przykładowo na płaszczyźnie ekonomicznej, społecznej czy bytowej, a co za tym idzie zarówno w swoim domu, jak i środowisku pracy.

Pożar, czyli niekontrolowany proces spalania i rozprzestrzeniania się ognia [Kociołek 2019], jest jednym z wielu zagrożeń, które mogą wystąpić w miejscu pracy, dlatego, aby zminimalizować ryzyko jego wystąpienia, stosuje się odpowiednie środki i działania mające na celu ochronę. Przykładem takich działań jest sporządzenie instrukcji bezpieczeństwa pożarowego, planów ewakuacji, zapewnienie odpowiedniego sprzętu gaśniczego czy szkolenia pracowników.

Ze zjawiskiem pożaru wiążą się trzy czynniki, które można umieścić na tzw. trójkącie pożaru. Są to materiał palny, utleniacz i energia cieplna. Materiałem palnym jest taki materiał, który pod wpływem utleniacza może zostać utleniony. Może on występować w różnych stanach skupienia, tj. ciała stałe - drewno, węgiel, papier; ciecze - benzyna, alkohol, smoła; gazy - metan, propan. Utleniaczem podczas pożaru zazwyczaj jest tlen ze względu na to, iż występuje w powietrzu (stanowi około $21 \%$ jego składu). Ostatni czynnik, czyli energia cieplna, jest bodźcem energetycznym niosącym ze sobą taką ilość ciepła, która jest konieczna do zapoczątkowania reakcji spalania. Energia ta jest różna dla różnych materiałów palnych, a jej źródłem może być otwarty płomień, żar lub iskra [Małozięć i Koniuch 2009].
\end{abstract}

\footnotetext{
${ }^{1}$ Uniwersytet Przyrodniczy w Lublinie, Wydział Inżynierii Produkcji, Międzywydziałowe Studenckie Koło Naukowe Ergonomii i BHP

${ }^{2}$ Uniwersytet Przyrodniczy w Lublinie, Wydział Inżynierii Produkcji

${ }^{3}$ mistal444@gmail.com
} 
Pożary można podzielić na grupy w zależności od materiału palnego oraz jego stanu skupienia. Podział ten warunkuje użycie różnych środków gaśniczych do ugaszenia ognia. Ze względu na rodzaj materiału palnego podział pożarów przedstawia się następująco:

- grupa A - pożary stałych materiałów organicznych, których spalanie zachodzi wraz ze zjawiskiem żarzenia, np. drewna, węgla, papieru, słomy,

- grupa B - pożary cieczy i materiałów stałych topiących się, np. benzyna, alkohol, smoła, nafta,

- grupa C - pożary gazów, np. metanu, acetylenu, propanu, wodoru,

- grupa D - pożary metali, np. sodu, potasu, magnezu,

- grupa E - pożary thuszczów i olejów jadalnych, głównie w urządzeniach kulinarnych [PN-EN 2:1998/A1:2006].

Możliwość rozprzestrzeniania się pożaru między budynkami ogranicza się zwykle przez zapewnienie odpowiednich odległości między ścianami zewnętrznymi budynków [Kosiorek 2015]. Rozwój i rozprzestrzenianie się pożaru jest więc częściowo uzależnione od konstrukcji oraz rozwiązań techniczno-budowlanych zastosowanych w budynku. Rozprzestrzenianie ognia może następować poprzez: zapalenia się izolacji, uszczelek, niewłaściwą konstrukcję ściany, przerzut między oknami [Kosiorek 2015], palne materiały i elementy konstrukcji oraz wystroju budynku, np. łatwopalna wykładzina [IBP 2014]. Na rozwój pożaru wpływają także czynniki wywołane nieuwagą ludzką, takie jak: późne zauważenie pożaru, zastawienie drogi pożarowej, nieznajomość zasad postępowania na wypadek wystąpienia pożaru, niesprawny technicznie sprzęt gaśniczy w wyposażeniu budynku, niewłaściwie podany meldunek do straży pożarnej [IBP 2014].

W celu zapewnienia bezpieczeństwa pożarowego, budynki wyposaża się także w sprzęt gaśniczy, taki jak: gaśnice, hydranty, koce gaśnicze, hydronetki wodne.

Ewakuacja polega na zorganizowanym przemieszczeniu ludzi, zwierząt i dóbr materialnych ze strefy zagrożonej do miejsca bezpiecznego [Przeworski 2002]. Ponadto każdy budynek musi spełniać odpowiednie warunki umożliwiające ewakuację ludności. Są to m.in. wymagania techniczne dotyczące zapewnienia dostatecznej liczby, wysokości, szerokości wyjść ewakuacyjnych; długości, szerokości, wysokości przejść ewakuacyjnych oraz ich odpowiedniego oznakowania i oświetlenia [Dz.U. nr 109 poz. 719]. Istnieje pewien stały element przeprowadzania działań ewakuacyjnych, mianowicie z budynku zagrożonego zawsze w pierwszej kolejności wyprowadza się ludzi, następnie zwierzęta, a na końcu dobra materialne. Nie istnieje jednak jedyna poprawna kolejność ratowania ludzi, a w przypadku nieprzewidywalnego rozwoju sytuacji decyzję podejmują osoby dowodzące, które pod uwagę biorą stopień zagrożenia [Bielicki 2009]. Warto znać jednak stały układ opisujący kolejność opuszczania pomieszczeń. Zgodnie z nim jako pierwsze ewakuuje się pomieszczenia bezpośrednio objęte pożarem, następnie te, które z nim sąsiadują oraz znajdujące się na kondygnacji powyżej. Na końcu ewakuuje się pomieszczenia znajdujące się na kondygnacji poniżej [IBP 2014].

Ochrona przeciwpożarowa, zgodnie z ustawą o ochronie przeciwpożarowej (tekst jedn.: Dz.U. 2020 poz. 961) obejmuje wszelkie działania zapobiegające powstawaniu oraz rozprzestrzenianiu się pożaru, klęsk żywiołowych i innych miejscowych zagrożeń, jak również zapewnia siły i środki do ich zwalczania. Polega także na prowadzeniu działań ratowniczych w sytuacjach zagrożenia, a wszystko to ma na celu ochronę życia, zdrowia i mienia ludzkiego oraz środowiska. Zapewnienie ochrony przeciwpożarowej jest jednym z zadań właściciela budynku lub terenu. Ta sama ustawa narzuca na niego obowiązki: 
- przestrzegania wymagań techniczno-budowlanych w obiekcie,

- wyposażenia obiektu w urządzenia przeciwpożarowe i gaśnicze,

- zapewnienia konserwacji sprzętu przeciwpożarowego,

- zapewnienia użytkownikom obiektu możliwości ewakuacji,

- przygotowania obiektu do ewentualnej akcji ratowniczej,

- zapoznania pracowników z obowiązującymi przepisami dotyczącymi ochrony przeciwpożarowej,

- ustalenia sposobu postępowania w przypadku zagrożenia [Dz.U. $2020 \mathrm{nr}$ 961].

Kontrola bezpieczeństwa pożarowego polega na sprawdzeniu przestrzegania przepisów pożarowych $\mathrm{w}$ obiekcie oraz ocenie rozwiązań technicznych względem zgodności z wymaganiami ochrony przeciwpożarowej [Dz.U. $2005 \mathrm{nr} 225$ poz. 1934]. Osobami uprawnionymi do przeprowadzania takiej kontroli są strażacy PSP mający co najmniej 6 miesięcy służby stałej i wykształcenie wyższe bądź stopień aspirancki oraz inne osoby posiadające wyższe wykształcenie i uprawnienia. Aktami prawnymi regulującymi zakres kontroli są art. 62 ustawy o prawie budowlanym z dnia 7 lipca 1994 r. [Dz.U. 2020 poz. 1333] oraz Rozporządzenie Ministra Spraw Wewnętrznych i Administracji z dnia 7 czerwca 2010 r. [Dz.U. 2010 nr 109 poz. 719].

\section{Material badawczy}

Badania zostały przeprowadzone w jednym ze świętokrzyskich domów pomocy społecznej, który jest przeznaczony na pobyt stały dla osób wymagających opieki z powodu wieku, choroby oraz niepełnosprawności. Działa on jako jeden z elementów pomocy społecznej mającej na celu udzielenie pomocy i wsparcia osobom oraz rodzinom, które znalazły się $\mathrm{w}$ trudnej sytuacji życiowej i nie są w stanie sobie $\mathrm{z}$ nią poradzić [Dz.U. 2019 poz. 1507]. Budynek omawianego domu pomocy społecznej przeznaczony jest na pobyt dla 220 osób, natomiast w momencie prowadzenia badań zamieszkiwało go 149 podopiecznych. Zatrudnionych natomiast było 102 pracowników. Dodatkowo z danych technicznych budynku warto zaznaczyć, iż jest to obiekt wielokondygnacyjny (piwnica, parter, I, II, III piętro) oraz ma wysokość 12,03 m, co zalicza go do budynków średniowysokich. Ze względu na pełnioną funkcję (miejsce przeznaczone dla osób z ograniczoną zdolnością poruszania się) budynek ten, jak również każdy inny dom pomocy społecznej, na mocy rozporządzenia Ministra Infrastruktury z dnia 12 kwietnia $2002 \mathrm{r}$. w sprawie warunków technicznych, jakim powinny odpowiadać budynki i ich usytuowanie (Dz.U. 2019 poz. 1065), zalicza się do kategorii zagrożenia ludzi ZL II.

\section{Metody badawcze, organizacja i przebieg badań}

Do przeprowadzenia badań wykorzystano autorską listę kontrolną zawierającą 38 pytań, które zostały podzielone na poszczególne kategorie:

- ogólne - 5 pytań, które miały na celu przede wszystkim sprawdzenie, czy pracownicy posiadają należytą wiedzę na temat przepisów przeciwpożarowych oraz czy obiekt posiada odpowiednią dokumentację (m.in. instrukcję bezpieczeństwa pożarowego);

- instalacje użytkowe obiektu - 3 pytania, które dotyczyły głównie poddawania badaniom okresowym i przeglądom technicznym tychże instalacji; 
- sprzęt przeciwpożarowy - 14 pytań skupiających się głównie na poddawaniu sprzętu przeglądom technicznym i czynnościom konserwacyjnym; pytania dotyczyły także ulokowania sprzętu (dostępu do niego, oznakowania) oraz jego odpowiedniej ilości w obiekcie;

- ewakuacja - 9 pytań, które dotyczyły przede wszystkim wymagań technicznych i oznakowania przejść oraz wyjść ewakuacyjnych, ale także wiedzy pracowników w przypadku konieczności ewakuacji;

- drogi pożarowe i przeciwpożarowe, zaopatrzenie w wodę - 3 pytania sprawdzające czy budynek posiada drogi pożarowe, którymi mogą dojechać służby ratunkowe oraz czy spełniają one odpowiednie wymagania techniczne;

- zagrożenie pożarem lub wybuchem - 4 pytania dotyczące występowania i składowania materiałów łatwopalnych i niebezpiecznych pożarowo.

Autorska lista kontrolna została sporządzona na podstawie następujących aktów prawnych:

- Rozporządzenie Ministra Spraw Wewnętrznych i Administracji z dnia 7 czerwca 2010 r. w sprawie ochrony przeciwpożarowej budynków, innych obiektów budowlanych i terenów (Dz.U. $2010 \mathrm{nr} 109$ poz. 719),

- Ustawa o ochronie przeciwpożarowej z dnia 24 sierpnia 1991 r. (Dz.U. z 2020, poz. 961$), 28$

- Ustawa o prawie budowlanym z dnia 7 lipca 1994 r. (Dz.U. 2020 poz. 1333),

- Ustawa z dnia 26 czerwca 1974 r. - Kodeks pracy (Dz.U.2020.0.1320),

- Rozporządzenie Ministra Infrastruktury z dnia 12 kwietnia 2002 r., w sprawie warunków technicznych, jakim powinny odpowiadać budynki i ich usytuowanie (Dz.U. 2019 poz. 1065),

- Ustawa z dnia 9 listopada 1995 r. o ochronie zdrowia przed następstwami używania tytoniu i wyrobów tytoniowych (Dz.U. 2019 poz. 638).

Kolejnym ważnym elementem przeprowadzania badań była szczegółowa analiza dostępnej dokumentacji obiektu. Wgląd uzyskano do:

- Protokołu z testów głównego wyłącznika prądu oraz badania instalacji odgromowej,

- Karty konserwacji systemu oddzieleń pożarowych głównej klatki schodowej,

- Protokołu z pomiarów ochronnych instalacji elektrycznych,

- Protokołu z kontroli przewodów kominowych,

- Protokołu z przeglądu rocznego instalacji gazowej zgodnie z wytycznymi Głównego

Urzędu Nadzoru Budowlanego,

- Instrukcji Bezpieczeństwa Pożarowego,

- Planów budynku oraz rozmieszczenia sprzętu pożarniczego,

- Karty konserwacji systemu sygnalizacji pożarowej,

- Karty konserwacji systemu oddymiania klatek schodowych,

- Karty konserwacji dźwiękowego systemu ostrzegawczego.

Ostatnim elementem było przeprowadzenie wywiadów z pracownikami Domu Pomocy Społecznej, które pozwoliły ustalić ich wiedzę na temat przepisów ochrony przeciwpożarowej oraz postępowania w przypadku wystąpienia pożaru na terenie zakładu pracy.

Kontrola została przeprowadzona w dniach 21.09.2020 - 23.09.2020. 


\section{Wyniki badań}

Początkowe pytania listy kontrolnej dotyczące informacji ogólnych skupiły się na podstawowych, ale bardzo ważnych aspektach ochrony przeciwpożarowej, m.in. posiadaniu instrukcji bezpieczeństwa pożarowego i znajomości przepisów przez pracowników. Kontrolowany obiekt posiada taką instrukcję, której sporządzenie i wdrożenie jest regulowane $\S 6$ Rozporządzenia Ministra Spraw Wewnętrznych i Administracji z dnia 7 czerwca 2010 r. w sprawie ochrony przeciwpożarowej budynków, innych obiektów budowlanych i terenów (Dz.U. $2010 \mathrm{nr} 109$ poz. 719). Dzięki wywiadom udało się ustalić, że pracownicy są odpowiednio przeszkoleni z zakresu przepisów. Na mocy ww. rozporządzenia muszą oni zostać zaznajomieni z IBP, ale także zgodnie $\mathrm{z}$ art. 4 ustawy o ochronie przeciwpożarowej z dnia 24 sierpnia 1991 r. (Dz.U. z 2020 poz. 961) z przepisami przeciwpożarowymi. W przypadku wystąpienia w obiekcie pożaru bardzo ważne jest szybkie działanie. O ile pracownicy wiedzą, jak się zachować, tak osoby z zewnątrz przychodzące do obiektu nie mają takiego obowiązku. W związku z tym istnieje konieczność umieszczenia w widocznych miejscach instrukcji na wypadek wystąpienia takiego zagrożenia oraz wykaz telefonów alarmowych. Obserwacja pozwoliła ustalić, iż w kontrolowanym obiekcie takie tablice zostały wywieszone np. przy wejściach głównych oddziałów czy portierni.

Jednym z warunków, jakie muszą być spełnione, aby prawidłowo i bezpiecznie użytkować obiekt, jest posiadanie sprawnych instalacji m.in. elektrycznej, gazowej, odgromowej i grzewczej. Pewność w ich działaniu mogą dać jedynie odpowiednio często przeprowadzane kontrole, o których konieczności zapis znajduje się w art. 62 ustawy o prawie budowlanym z dnia 7 lipca 1994 r. (Dz.U. 2020 poz. 1333). Zgodnie z tą ustawą właściciel obiektu ma obowiązek przeprowadzać kontrolę stanu instalacji gazowej oraz grzewczej (przewody kominowe) co najmniej $1 \mathrm{raz} \mathrm{w}$ roku, natomiast instalacji elektrycznej i odgromowej nie rzadziej niż raz na 5 lat. Wgląd do odpowiedniej dokumentacji, która została wymieniona w części „Metody badawcze, organizacja i przebieg badań" tego artykułu pozwolił ustalić, że kontrolowany obiekt wywiązywał się z tych obowiązków. Ponadto Rozporządzenie Ministra Spraw Wewnętrznych i Administracji z dnia 7 czerwca 2010 r. w sprawie ochrony przeciwpożarowej budynków, innych obiektów budowlanych i terenów (Dz.U. $2010 \mathrm{nr} 109$ poz. 719) narzuca na właściciela obiektu umieszczenie przeciwpożarowego wyłącznika prądu blisko wejścia do obiektu oraz kontrolę jego stanu technicznego nie rzadziej niż 1 raz do roku. Również wgląd do dokumentacji, a dodatkowo obserwacja własna potwierdziły, iż obiekt spełnia ten wymóg. Fotografia 1 przedstawia przeciwpożarowy wyłącznik prądu znajdujący się w kontrolowanym DPS.

W miejscach, w których może wystąpić pożar, występują różne materiały mogące ulec spalaniu. Konieczne jest więc posiadanie odpowiednich gaśnic, które będą przeznaczone do danych grup pożarów. Zgodnie z Polską Normą PN-EN 2;1998/A1:2006 „Podział pożarów” wymienia się następujące grupy: A - pożary stałych materiałów organicznych, np. drewna, węgla, papieru; B - pożary cieczy i materiałów stałych topiących się, np. benzyna, smoła; C - pożary gazów, np. metanu, acetylenu; D - pożary metali, np. sodu, magnezu; F - pożary tłuszczów i olejów jadanych. Obowiązkiem właściciela jest także zapewnienie odpowiedniej ilości środka gaśniczego. Oba te aspekty reguluje Rozporządzenie Ministra Spraw Wewnętrznych i Administracji z dnia 7 czerwca 2010 r. w sprawie ochrony przeciwpożarowej budynków, innych obiektów budowlanych i terenów (Dz.U. $2010 \mathrm{nr} 109$ poz. 719). Na każde $100 \mathrm{~m}^{2}$ powierzchni obiektu powinno przypadać 


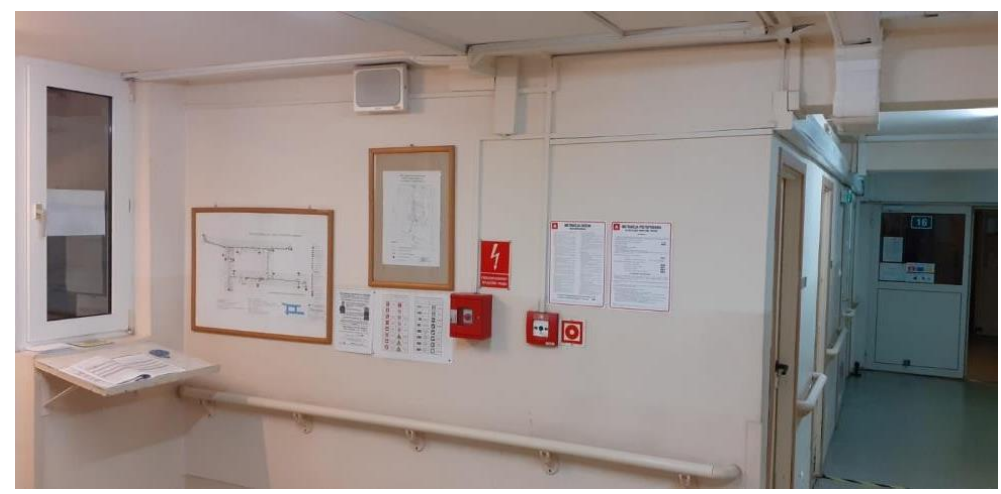

Fot. 1. Przeciwpożarowy wyłącznik prądu (fot. własna)

dać $2 \mathrm{~kg}$ (lub $3 \mathrm{dm}^{3}$ ) środka gaśniczego. W kontrolowanym Domu Pomocy Społecznej znajdują się następujące rodzaje gaśnic:

- 2 sztuki gaśnicy proszkowej GP $12 \mathrm{~kg} \mathrm{ABC;}$

- 47 sztuk gaśnicy proszkowej GP 6 kg ABC;

- 13 sztuk gaśnicy proszkowej GP 2 kg ABC;

-2 sztuki gaśnicy śniegowej $5 \mathrm{~kg}$ GS $-5 \times \mathrm{B}$;

- 1 sztuka gaśnicy płynowej, gastronomicznej GWG 2 kg AF.

$\mathrm{Na}$ tej podstawie można policzyć, iż łącznie w obiekcie jest $344 \mathrm{~kg}$ środka gaśniczego. Przy powierzchni obiektu wynoszącej $11440,5 \mathrm{~m}^{2}$ powinno być go minimalnie $229 \mathrm{~kg}$, a więc obecna ilość jest nawet znacznie większa. Gaśnice są również przeznaczone do odpowiednich grup pożaru $-\mathrm{z}$ instrukcji bezpieczeństwa pożarowego sporządzonej dla kontrolowanego DPS wynika, iż w obiekcie mogą wystąpić pożary z grup A, $\mathrm{B}, \mathrm{C}$ i $\mathrm{F}$, natomiast wyposażony jest $\mathrm{w}$ gaśnice do gaszenia pożarów $\mathrm{z}$ grup $\mathrm{ABC}, \mathrm{AF}$ i B. Na tej podstawie wiadomo, że wymogi rozporządzenia zostały spełnione. Fotografia 2 przedstawia dwie gaśnice znajdujące się w kontrolowanym obiekcie.

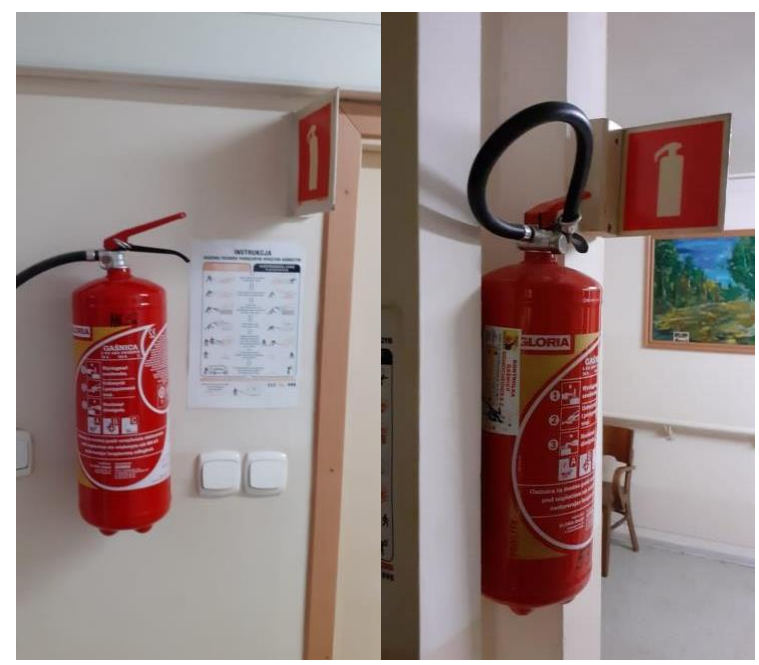

Fot. 2. Gaśnice w kontrolowanym obiekcie (fot. własna) 


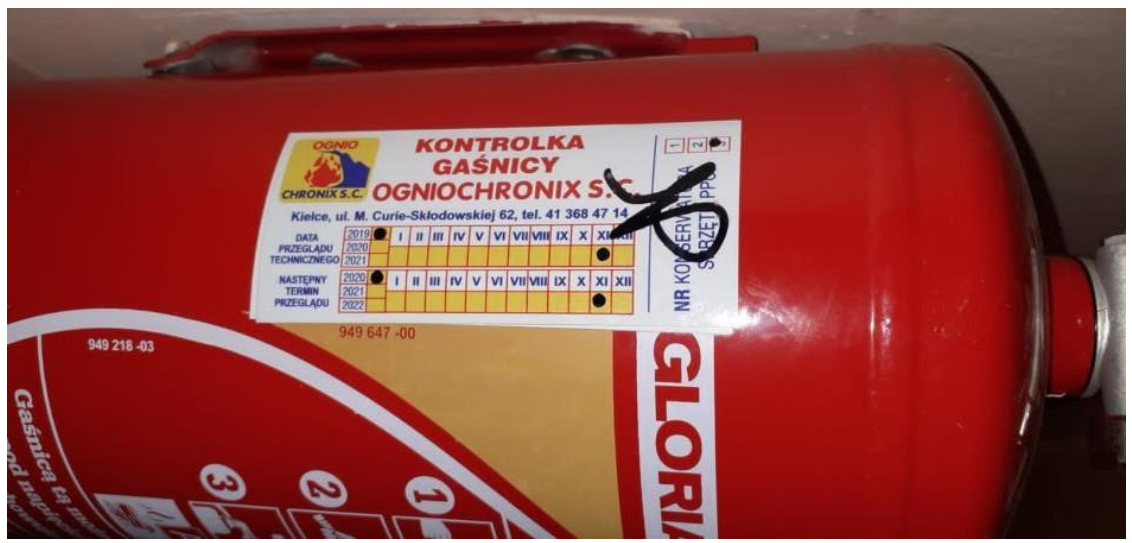

Fot. 3. Kontrolka gaśnicy (fot. własna)

Kolejnym ważnym elementem bezpieczeństwa pożarowego jest sprawność sprzętu gaśniczego, dlatego zgodnie z $\S 3$ ww. rozporządzenia sprzęt należy poddawać kontroli i czynnościom konserwacyjnym, a po tej czynności opatrzyć je „kontrolką”. Fotografia 3 przedstawia jedną z takich kontrolek, która została przyklejona na gaśnicę występującą w kontrolowanym obiekcie.

Miejsca, w których zlokalizowany jest sprzęt gaśniczy muszą być odpowiednio oznakowane (zgodnie z Polską Normą PN-92/N01256/01). W świętokrzyskim domu pomocy społecznej, w którym przeprowadzono badania, każde urządzenie gaśnicze oznaczone jest odpowiednim znakiem bezpieczeństwa pożarowego, co zostało ustalone dzięki obserwacji własnej.

Innym ważnym aspektem jest właściwe zachowanie w przypadku wystąpienia zagrożenia, a więc także przy konieczności ewakuacji. Zgodnie z Instrukcją Bezpieczeństwa Pożarowego, pracownicy są zobowiązani podporządkować się osobie dowodzącej, znają rozmieszczenie dróg i wyjść ewakuacyjnych w budynku, potrafią posługiwać się podręcznym sprzętem gaśniczym oraz znają środki łączności i alarmowania straży pożarnej i innych jednostek ratowniczych. Jak wcześniej wspomniano, pracownicy domu pomocy społecznej zostali zapoznani z instrukcją, co potwierdza, iż wiedzą jak zachować się w przypadku ewakuacji.

Rozporządzenie Ministra Infrastruktury z dnia 12 kwietnia 2002 r. w sprawie warunków technicznych, jakim powinny odpowiadać budynki i ich usytuowanie (Dz.U. 2019 poz. 1065) omawia warunki techniczne, jakie powinny spełniać drogi, przejścia oraz wyjścia ewakuacyjne Są to $\mathrm{m}$. in.:

- długość przejścia, która nie może przekraczać 40 metrów;

- szerokość dróg ewakuacyjnych, która musi wynosić co najmniej 1,4 m oraz wysokość min. 2,2 m;

- szerokość wyjść, która powinna wynosić co najmniej 0,6 m na 100 osób.

Wszystkie parametry dotyczące przejść, wejść czy dróg ewakuacyjnych w badanym domu pomocy społecznym są zachowane i zgodne z powyższym rozporządzeniem. 


\section{Wnioski i podsumowanie}

Przeprowadzona kontrola stanu bezpieczeństwa pożarowego pozwoliła ustalić, iż $\mathrm{w}$ domu pomocy społecznej spełnione są najważniejsze wymogi z zakresu bezpieczeństwa pożarowego. Na podstawie przeprowadzonych badań można sformułować wnioski, iż kontrolowany dom pomocy społecznej:

- posiada ważną i odpowiednio często aktualizowaną Instrukcję Bezpieczeństwa Pożarowego;

- jest prawidłowo oznakowany znakami bezpieczeństwa pożarowego, m.in. oznakowane są miejsca ulokowania sprzętu gaśniczego, drogi oraz wyjścia ewakuacyjne. Dodatkowo w obiekcie umieszczone są tabliczki zawierające instrukcje postępowania w przypadku wystąpienia pożaru oraz numery alarmowe;

- jest wyposażony w gaśnice przeznaczone do grup pożarów mogących wystąpić w obiekcie, ponadto zapewniona jest odpowiednia ilość środka gaśniczego, a sprzęt poddawany jest kontrolom sprawności technicznej oraz czynnościom konserwacyjnym z odpowiednią częstotliwością;

- posiada drogi, przejścia oraz wyjścia ewakuacyjne, które spełniają wymogi techniczne zawarte w rozporządzeniu Ministra Spraw Wewnętrznych i Administracji.

Ponadto:

- instalacje użytkowe w obiekcie są sprawne i kontrolowane z odpowiednią częstotliwością;

- pracownicy są zapoznani z przepisami przeciwpożarowymi, Instrukcją Bezpieczeństwa Pożarowego oraz wiedzą, jak zachować się w przypadku wystąpienia zagrożenia i konieczności ewakuacji.

Kontrolowany dom pomocy społecznej spełnia najważniejsze wymogi z zakresu ochrony przeciwpożarowej, co sprawia, że obiekt jest bezpieczny dla pracowników, podopiecznych i innych osób go użytkujących, a wszystkie działania i zabezpieczenia mają na celu ochronę ich zdrowia i życia. Warunki techniczno-budowlane badanego obiektu zapewniają możliwość bezpiecznej ewakuacji, a zastosowane zabezpieczenia przeciwpożarowe zapewniają akceptowalny poziom bezpieczeństwa przeciwpożarowego.

\section{Bibliografia}

Bielicki P., 2009. Ewakuacja ludzi, zwierząt i mienia. W: System szkolenia członków Ochotniczych Straży Pożarnych biorących bezpośredni udział w działaniach ratowniczych, Szkolenie strażaków ratowników OSP część I. CNBOP, Józefów, 188-217.

IBP - Instrukcja bezpieczeństwa pożarowego dla Domu Pomocy Społecznej im. Jana Pawła II w Kielcach, 2014. Opracowanie - przedsiębiorstwo handlowo-techniczne SUPON Sp. z o.o., Kielce.

Kociołek K.T., 2019. Poradnik inspektora ochrony przeciwpożarowej. Tarbonus, KrakówTarnobrzeg.

Korzeniowski L., 2000. Zarządzanie bezpieczeństwem. Rynek, ryzyko, zagrożenie, ochrona. W: P. Tyrała (red.), Zarządzanie bezpieczeństwem, PSB, Kraków, 437-444.

Kosiorek M., 2015. Podczas pożaru - funkcje budynku i jego elementów. Szkoła Główna Służby Pożarniczej, Builder.

Małozięć D., Koniuch A., 2009. Proces spalania a pożar. W: Sural Z. (red.), System szkolenia członków Ochotniczych Straży Pożarnych biorących bezpośredni udział w działaniach ratowniczych, Szkolenie Strażaków Ratowników OSP, część I. CNBOP. 
Polska Norma PN-EN 2:1998/A1:2006 Podział pożarów.

Przeworski K., 2002. Ewakuacja jako sposób ochrony ludności. AON, Warszawa.

Rozporządzenie Ministra Infrastruktury z dnia 12 kwietnia 2002 r. w sprawie warunków technicznych, jakim powinny odpowiadać budynki i ich usytuowanie (Dz.U. 2019 poz. 1065).

Ustawa z dnia 26 czerwca 1974 r. - Kodeks pracy (Dz.U.2020.0.1320).

Ustawa o ochronie przeciwpożarowej z dnia 24 sierpnia 1991 r. (tekst jedn.: Dz.U. z 2020 poz. 961).

Ustawa o pomocy społecznej z dnia 12 marca 2004 r. (Dz.U. 2019 poz. 1507). 
Piotr Ostrowski $^{1,3}$, Jakub Chalimoniuk ${ }^{1}$, Natalia Kanadys ${ }^{1}$, Gabriela Michta ${ }^{1}$, Kamila Rybczyńska-Tkaczyk ${ }^{2}$

\section{Perspektywy wykorzystania mikroorganizmów do biodegradacji cytostatyków}

Prospects for using microorganisms for biodegradation of cytostatics

Standardem leczenia chorób nowotworowych jest terapia $\mathrm{z}$ wykorzystaniem związków chemicznych, tzw. cytostatyków. Rośnie jednocześnie zainteresowanie ich niekorzystnym wpływem na środowisko. Niniejsza praca ma na celu charakterystykę toksyczności oraz metod degradacji cytostatyków, zwłaszcza możliwość zastosowania grzybów białej zgnilizny drewna i ich enzymów.

\section{Charakterystyka cytostatyków}

Celem stosowania leków przeciwnowotworowych jest zniszczenie lub zahamowanie wzrostu komórek nowotworowych. Ze względu na mechanizm działania leki te można podzielić na klasyczne leki cytotoksyczne stosowane w chemioterapii, leki oddziałujące na hormony, leki ukierunkowane molekularnie oraz leki stymulujące układ immunologiczny. Cytostatyki stosowane w chemioterapii są grupą naturalnych lub syntetycznych związków używanych podczas chemioterapii do walki z rakiem ze względu na ich wysoką toksyczność względem komórek nowotworowych. Mechanizm ich działania opiera się na zaburzeniu cyklu komórkowego, czego efektem jest zahamowanie rozwoju i podziałów komórek, a w końcowym stadium ich śmierć [Balcerzak i Rezka 2014, Martin i in. 2014]. Mogą one oddziaływać z komórkami w różnych fazach cyklu komórkowego lub wykazywać charakter nieswoisty, jak cytostatyki z grupy leków alkilujących. Ze względu na mechanizm działania cytostatyki można podzielić na następujące grupy:

- leki alkilujące wiążące się kowalencyjnie z DNA lub RNA (np. cyklofosfa$\operatorname{mid}(\mathrm{CP})$, chlorambucyl, daunomycyna, doksyrubicyna);

- antymetabolity hamujące enzymy uczestniczące w syntezie kwasów nukleinowych (np. metotreksat, kapecytabina, 5-fluorouracyl (5-FU));

- inhibitory topoizomerazy - hamują działanie izomeraz, uniemożliwiając syntezę DNA (np. topotekan, irinotekan);

\footnotetext{
${ }^{1}$ Uniwersytet Przyrodniczy w Lublinie, Wydział Agrobioinżynierii, Studenckie Koło Naukowe Analityków Środowiska

${ }^{2}$ Uniwersytet Przyrodniczy w Lublinie, Wydział Agrobioinżynierii, Katedra Mikrobiologii Środowiskowej

${ }^{3}$ piotr117@vp.pl 
- antybiotyki cytotoksyczne - zakłócające działanie DNA lub zaburzające jego syntezę (np. bleomycyna, mitomycyna) [Petit i in. 2017].

\section{Występowanie w wodach i metody degradacji}

W zależności od stosowanego w szpitalu profilu terapeutycznego, w ściekach mogą znajdować się związki cytostatyczne należące do różnych grup. Martin i in. [2014] podczas badań przeprowadzonych w hiszpańskiej Sewilli wykazali występowanie 14 leków cytostatycznych (m. in. cytarabina, cyklofosfamid, doksorubicyna, 5-fluorouracyl) w ciągu 1 roku. Isidori i in. [2016] wykryli podobną ilość (12) wśród ścieków pochodzących z dwóch szpitali zlokalizowanych na Słowenii i Hiszpanii. Na podstawie wyników ich badań stwierdzić można, że ścieki pochodzące z większych szpitali cechują się niższą koncentracją tych związków. Wpływ na to ma rozrzedzenie wody przez ścieki pochodzące z oddziałów innych niż onkologiczny.

Z kolei Santos i in. [2018] przy użyciu ekstrakcji do fazy stałej połączonej z chromatografią cieczową z udziałem spektrometrii mas w trybie mieszanym z jonizacją przez elektrorozpylanie (SPE LC-MS) wykryli obecność w trzech portugalskich rzekach kwasu mykofenolowego (MPA). Zmierzone wartości mieściły się w przedziale $210-541 \mathrm{ng} \mathrm{L}^{-1}$. Są one zgodne $\mathrm{z}$ wynikami badań przeprowadzonymi na innych rzekach europejskich. Zmierzone przez inne zespoły badaczy wartości mieszczą się w przedziale $89,5-656 \mathrm{ng} \mathrm{L}^{-1}$ [Giebułtowicz i Nałęcz-Jawecki 2016, Santos i in. 2017].

Wody powierzchniowe mają wpływ na zasoby wody pitnej, dlatego ważna jest ocena chemiczna wody po jej oczyszczeniu. Mimo to w literaturze można znaleźć nieliczne prace opisujące wykrywaniu związków cytostatycznych w wodzie pitnej. Frenquet-Griell i in. [2016] podają, że w próbkach pobranych z rzeki Besòs przepływającej przez region Katalonii wykryto między innymi obecność bleomycyny (stężenie $1,3 \times 10^{-5} \mathrm{mg} / \mathrm{l}$ ), w Barcelonie oznaczono zawartość MPA w stężeniu $1,7 \times 10^{-5}$ do $5,62 \times 10^{-5} \mathrm{mg} / 1 \mathrm{w}$ zależności od ujęcia wody [Mendoza $\mathrm{i}$ in. 2016, Franquet-Griell i in. 2017]. Z kolei Ghafuri i in. [2017] w wodach gruntowych regionu Qom w Iranie stwierdzili obecność kompleksów platyny pochodzących z leków alkilujących dwuwartościową platynę (cisplatynę, karboplatynę oraz oksaliplatynę) $\mathrm{w}$ stężeniach od 3,7 (oksaliplatyna) do 5,6 (cisplatyna) $\times 10^{-5} \mathrm{mg} / 1$.

Obecność wysokich stężeń cytostatyków w wodach powierzchniowych wskazuje na ich dużą stabilność w procesie oczyszczania ścieków. W celu ograniczenia przedostawania się cytostatyków do środowiska konieczne jest opracowanie wysokowydajnych metod oczyszczania ścieków [Ikehata i in. 2006]. Metody oparte na utlenianiu cytostatyków wykazują potencjalną wysoką wydajność wynoszącą np. dla 5-FU do $100 \%$ w zależności od warunków prowadzenia reakcji [Ochoa-Chavez i in. 2018]. Podczas badań przeprowadzonych przez Garcię-Ac i in. [2010] zastosowano ozonowanie do usunięcia metotreksatu oraz cyklofosfamidu. Zastosowana metoda okazała się skuteczna tylko w przypadku metotreksatu. Wadą zastosowanej metody jest wysoka zależność wydajności od pH oraz potencjalne ryzyko wysokiej toksyczności produktów utleniania. Również utlenianie elektrochemiczne, polegające na utlenianiu ksenobiotyku na anodzie, z wykorzystaniem elektrod BDD (elektrody diamentowe domieszkowane borem) wykazuje wysoką zależność od $\mathrm{pH}$ ze względu na wpływ zjonizowanych form leków na wydajność procesu [Fabiańska i in. 2014, Siedlecka i in. 2018]. 


\section{Wpływ na organizmy}

DNA jest związkiem niosącym informację genetyczną u wielu różnych grup organizmów. W związku z tym obecność cytostatyków w środowisku jest dużym obciążeniem dla fauny i flory wodnej, do której przedostają się one ze ściekami. Związki cytostatyczne są obciążeniem dla organizmów wodnych nawet w niskich stężeniach, ponieważ projektowane są tak, by wywoływać skutek biologiczny u człowieka w małych dawkach [Zounková i in. 2007]. Mogą one wywoływać zarówno ostrą, jak i przewlekłą toksyczność organizmów - szczególnie wodnych ze względu na medium, w którym występują [Balcerzak i Rezka 2014]

Zanieczyszczenia wody dzieli się na klasy toksyczności na podstawie wartości $\mathrm{EC}_{50}$ (ang. effective concentration), czyli stężenie skutecznie indukujące w środowisku określony efekt (np. działanie hamujące lub stymulujące procesy fizjologiczne) u 50\% badanych organizmów. Zgodnie z Dyrektywą UE 93/67/EWG wartości graniczne podawane są w jednostkach stężenia masowego $(\mathrm{mg} / \mathrm{l})$, które określa masę ksenobiotyku w 11 wody:

- bardzo toksyczne $-<1 \mathrm{mg} / \mathrm{l}$;

- toksyczne $-1-10 \mathrm{mg} / \mathrm{l}$;

- szkodliwe - 10-100 mg/l.

Większość badań środowiskowych skupia się na cytostatykach, stosowanych podczas chemioterapii najczęściej np. 5-fluorouracylu (5-FU), cyklofosfamidzie (CP) czy związkach należących do kompleksów platyny [Zounková i in. 2007, Mišík i in. 2015]. Mišík i in. [2019], oceniając zagrożenie dla środowiska ze strony 4 często występujących związków (5-FU, CisPt, mesylan imatinibu, etopozyd) nie stwierdzili wywoływania przez nie ostrej toksyczności. W badaniu nie brano jednak pod uwagę możliwości synergistycznego oddziaływania tych związków. Bleomycynę z kolei można zaliczyć do związków bardzo toksycznych, gdyż jej $\mathrm{EC}_{50} \mathrm{~W}$ stosunku do Lemma minor, Daphnia magna i Pseudomonas putida wynosiło odpowiednio $0,2 \mathrm{mg} / 1,0,77 \mathrm{mg} / \mathrm{l}$ oraz $7,27 \mathrm{mg} / \mathrm{l}$. Wykazywała ona znacznie wyższy stopień toksyczności w porównaniu z winkrystyną, która tylko w przypadku D. magna wykazywała działanie toksyczne $\left(\mathrm{EC}_{50}=7,74 \mathrm{mg} / \mathrm{l}\right)$ [Jureczko i Przystaś 2019]. Podczas badania przeprowadzonego przez Russo i in. [2018] wykazano wyższą od cyklofosfamidu toksyczność ifosfamidu. W badaniu ostrej toksyczności poddano Ceriodaphia dubia 7-dniowej ekspozycji ifosfamidem, co wywoływało spadek dzietności w stężeniu 15,84 mg/l. Wśród danych literaturowych istnieje mała ilość doniesień dotyczących wpływu związków cytotoksycznych na rośliny wyższe. Mišík i in. [2015] w prowadzonych badaniach skupili się na zbadaniu wrażliwości pyłków roślin wyższych. Wyniki wskazywały, że 5-fluorouracyl, cyplatyna i etopozyd wywołują aberracje DNA u przedstawicieli różnych rodzin roślin wyższych (Tipula paludosa, Arabidopsis thaliana, Chelidonium majus i Alisma plantago-aquatica). Przewidywane stężenia środowiskowe tych związków są jednak niższe od zaobserwowanych NOEC (ang. No Observed Efects Concentration), co wskazuje na brak zagrożenia w środowisku. Z kolei Załęska-Radziwiłł $\mathrm{i}$ in. [2011] wskazała, że 5-fluorouracyl jest bardzo toksyczny w stosunku do Lemna minor i Raphidocelis subcapitata. W badaniu wskazano na konieczność dalszego monitorowania środowiska oraz potrzebę rozwoju szybkich i dokładnych metod analitycznych oraz badań chronicznych efektów działania tych związków. 


\section{Usuwanie związków o działaniu cytostatycznym ze środowiska na drodze biodegradacji przez grzyby białej zgnilizny drewna}

Grzyby białej zgnilizny drewna (ang. - White Root Fungi - WRF) wykazują szereg cech, dzięki którym mogą znaleźć zastosowanie w efektywnym oczyszczaniu ścieków z substancji trudno biodegradowalnych, m.in. cytostatyków. Wpływ ma na to przede wszystkim:

- niespecyficzność wytwarzanych przez nie enzymów - w szczególności enzymów ligninolitycznych - umożliwia degradację szerokiej gamy ksenobiotyków;

- szybki wzrost grzybni;

- zdolność do degradacji związków w szerokim spektrum pH 3-9.

Jednocześnie grzyby do degradacji ksenobiotyków wymagają zewnętrznego, łatwo rozkładalnego źródła węgla. Znaczy to, że degradacja trwałych zanieczyszczeń jest procesem kometabolicznym [Rouches i in. 2016, Pereira i in. 2020].

W badaniach nad wykorzystaniem grzybów do degradacji cytostatyków, kluczową rolę mają enzymy ligninolityczne, m.in. lakaza (EC 1.10.3.2), oraz peroksydazy: mangano-zależna (EC 1.11.1.13) i uniwersalna (VP) (EC 1.11.1.16) [Ferrando-Climent 2015, Castellet-Rovira i in. 2018, Jureczko i in. 2020]. Wśród nich szczególnie ważna jest peroksydaza VP, ponieważ jest zdolna do utleniania substratów o niskim i wysokim potencjale redoks (m.in. fenolowych i niefenolowych dimery ligniny, barwników antrachinonowych) [Kunjadia $\mathrm{i}$ in. 2016].

Dane literaturowe wskazują, że szczep Trametes versicolor (ATCC®42530 ${ }^{\mathrm{TM}}$ ) wykazuje duże zdolności biodegradacji szeregu cytostatyków. Jest on zdolny m.in. do całkowitej degradacji ze ścieków szpitalnych tamoksifenu na drodze kombinowanego procesu sorpcji i biodegradacji [Ferrando-Climent 2015]. Jureczko i in. [2020] odnotowali stopień biodegradacji winkrystyny na poziomie $94 \%$ przez szczep Trametes versicolor CB8 już po 4 dniach rozwoju grzybni przy początkowym stężeniu leku na poziomie $10 \mathrm{mg} / \mathrm{L}$. Jednocześnie jedynym istotnym enzymem zaangażowanym $\mathrm{w}$ ten proces degradacji była lakaza.

Z kolei szczep Bjerkandera adusta CCBAS930 (= R59) nie angażuje lakazy w procesach biodegradacji antybiotyków antracyklinowych (doksorubicyna, daunomycyna). Jednocześnie już w pierwszych dniach hodowli stacjonarnych tego grzyba w obecności cytostatyków wykrywane były peroksydazy, wśród których najwyższą aktywnością charakteryzowała się peroksydaza uniwersalna [Rybczyńska-Tkaczyk i in. 2021]. Korniłłowicz-Kowalska i in. [2006] w swoich badaniach zaobserwowali, że efektywność procesu degradacji daunomycyny przez B. adusta (R59) zależy przede wszystkim od stężenia antybiotyku w środowisku. Toksyczność daunomycyny najprawdopodobniej wywoływała kumulację wolnych rodników, które spowodowały niespecyficzne reakcje zaburzające metabolizm komórek grzyba. Badany szczep po 20 dniach hodowli w warunkach stacjonarnych był zdolny do rozkładu ponad 90\% daunomycyny i doksorubicyny przy stężeniu początkowym wynoszącym $10 \mu \mathrm{g} / \mathrm{mL}$ [Rybczyńska-Tkaczyk i in. 2021].

Wykorzystanie grzybów do degradacji cytostatyków jest ograniczane przez konieczność dostarczania im w pożywce łatwo przyswajalnych związków węgla [Rouches i in. 2016, Pereira i in. 2020]. Utrudnia to proces oczyszczania ścieków oraz zwiększa poniesione podczas tego procesu koszty. Alternatywą może okazać się bezpośrednie zastosowanie enzymów ligninolitycznych. Przykładem mogą być wyniki badań Kelbert i in. [2020], którzy do biodegradacji doksorubicyny zastosowali lakazę. Przeprowadzo- 
ne testy pozwoliły na całkowitą degradację doksorubicyny w ciągu 4 godzin przy stężeniu $500 \mu \mathrm{g} / \mathrm{L}^{-1}$.

\section{Podsumowanie}

Do cytostatyków należą związki chemiczne o zróżnicowanej budowie. Ich obecność w środowisku wodnym jest niebezpieczna zarówno dla organizmów wodnych, jak i dla ludzi. W związku z tym wymagane jest opracowanie wydajnych metod oczyszczania ścieków z tych związków. Wśród metod chemicznych potencjalnie atrakcyjne wydają się metody oparte na utlenianiu (np. ozonowanie), jednak nie są one wydajne w stosunku do wszystkich związków. Opracowując biologiczne metody oczyszczania ścieków, skupić się przede wszystkim należy na wykorzystaniu grzybów białej zgnilizny drewna wykorzystujących do biodegradacji enzymy ligninolityczne. Trwają także badania nad zastosowaniem enzymów ligninolitycznych w układzie bez grzybni.

\section{Bibliografia}

Balcerzak W., Rezka P., 2014. Occurrence of anti-cancer drugs in the aquatic environment and efficiency of their removal - the selected issues. Czasop. Techniczne (Środowisko) 1-Ś (20), $11-18$.

Castellet-Rovira F., Lucas D., Villagrasa M., Rodríguez-Mozaz S., Barceló D., Sarrà M., 2018. Stropharia rugosoannulata and Gymnopilus luteofolius: promising fungal species for pharmaceutical biodegradation in contaminated water. J. Environ. Manag. 207, 396-404. https://doi.org/10.1016/j.jenvman.2017.07.052.

Fabiańska A., Białk-Bielińska A., Stepnowski P., Stolte S., Siedlecka E.M., 2014. Electrochemical degradation of sulfonamides at BDD electrode: Kinetics, reaction pathway and ecotoxicity evaluation. J. Hazard. Mater. 280, 579-87. doi:10.1016/j.jhazmat.2014.08.050.

Ferrando-Climent L., Cruz-Morató C., Marco-Urrea E., Vicent T., Sarrà M., Rodriguez-Mozaz S., Barceló D., 2015. Non conventional biological treatment based on Trametes versicolor for the elimination of recalcitrant anticancer drugs in hospital wastewater. Chemosphere 136, 9-19. doi:10.1016/j.chemosphere.2015.03.051.

Franquet-Griell H., Cornadó D., Caixach J., Ventura F., Lacorte S., 2017. Determination of cytostatic drugs in Besòs River (NE Spain) and comparison with predicted environmental concentrations. Environ. Sci. Pollut. Res. 24, 6492-6503. https://doi.org/10.1007/s11356-016-8337-y.

Garcia-Ac A., Broséus R., Vincent S., Barbeau B., Prévost M., Sauvé S., 2010. Oxidation kinetics of cyclophosphamide and methotrexate by ozone in drinking water. Chemosphere 79(11), 1056-1063. doi:10.1016/j.chemosphere.2010.03.032.

Ghafuri Y., Yunesian M., Nabizadeh R., Mesdaghinia A., Dehghani M.H., Alimohammadi M., 2017. Platinum cytotoxic drugs in the municipal wastewater and drinking water, a validation method and health risk assessment. Human Ecol. Risk Assess.: Intern. J. 24(3), 784-796. doi:10.1080/10807039.2017.1400372.

Giebułtowicz J., Nałęcz-Jawecki G., 2016. Occurrence of immunosuppressive drugs and their metabolites in the sewage-impacted Vistula and Utrata Rivers and in tap water from the Warsaw region (Poland). Chemosphere 148, 137-147. doi:10.1016/j.chemosphere.2015.12.135.

Ikehata K., Naghashkar N.J., El-Din M.G., 2006. Degradation of aqueous pharmaceuticals by ozonation and ad-vanced oxidation processes: A review. Ozone Sci. Eng. 28, 6, 353-414.

Isidori M., Lavorgna M., Russo C., Kundi M., Novak M., 2016. Chemical and toxicological characterisation of anticancer drugs in hospital and municipal wastewaters from Slovenia and Spain. Environ. Poll. 219, 275-287. doi:10.1016/j.envpol.2016.10.039. 
Jureczko M., Przystaś W., 2019. Ecotoxicity risk of presence of two cytostatic drugs: Bleomycin and vincristine and their binary mixture in aquatic environment. Ecotoxicol. Environ. Safety 172, 210-215. doi:10.1016/j.ecoenv.2019.01.074.

Jureczko M., Przystaś W., Krawczyk T., Gonciarz W., Rudnicka K., 2020. White-rot fungimediated biodegradation of cytostatic drugs-bleomycin and vincristine. J. Hazardous Materials 407, 124632 https://doi.org/10.1016/j.jhazmat.2020.124632.

Kelbert M., Pereira C.S., Daronch N.A., Cesca K., Michels C., de Oliveira D., Soares H.M., 2020. Laccase as an efficacious approach to remove anticancer drugs: a study of doxorubicin degradation, kinetic parameters, and toxicity assessment. J. Hazardous Materials 124520. doi:10.1016/j.jhazmat.2020.124520.

Korniłłowicz-Kowalska T., Wrzosek M., Ginalska G., Iglik H., Balcerz R., 2006. Identification and application of a new fungal strain Bjerkandera adusta R59 in decolorization of daunomycin wastes. Enzyme Microbial. Technol. 38(5), 583-590. doi:10.1016/j.enzmictec.2005.10.009.

Kunjadia P.D., Sanghvi G.V., Kunjadia A.P., Mukhopadhyay P.N., Dave G.S., 2016. Role of ligninolytic enzymes of white rot fungi (Pleurotus spp.) grown with azo dyes. SpringerPlus, 5(1). doi:10.1186/s40064-016-3156-7.

Martín J., Camacho-Muñoz D., Santos J.L., Aparicio I., Alonso E., 2014. Occurrence and ecotoxicological risk assessment of 14 cytostatic drugs in wastewater. Water, Air, Soil Poll. (3), 1-10.

Mendoza A., Zonja B., Mastroianni N., Negreira N., De Alda M.L., Pérez S., Barceló D., Gil A., Valcárcel Y., 2016. Drugs of abuse, cytostatic drugs and iodinated contrast media in tap water from the Madrid region (central Spain):A case study to analyse their occurrence and human health risk characterization. Environ. Intern. 86, 107-118. doi:10.1016/j.envint.2015.11.001

Miš́́k M., Filipic M., Nersesyan A., Kundi M., Isidori M., Knasmueller S., 2019. Environmental risk assessment of widely used anticancer drugs (5-fluorouracil, cisplatin, etoposide, imatinib mesylate). Water Res. 114953. doi:10.1016/j.watres.2019.114953.

Miš́́k M., Kundi M., Pichler C., Filipic M., Raine B., Mišíková K., Nersesyan A., Knasmueller S., 2016. Impact of common cytostatic drugs on pollen fertility in higher plants. Environ. Sci. Pollut. Res. 23, 14730-14738. https://doi.org/10.1007/s11356-015-4301-5.

Ochoa-Chavez A.S., Pieczyńska A., Fiszka Borzyszkowska A., Espinoza-Montero P.J., Siedlecka E.M., 2018. Electrochemical degradation of 5-FU using a flow reactor with BDD electrode: Comparison of two electrochemical systems. Chemosphere 201, 816-825. doi:10.1016/j.chemosphere.2018.03.050.

Pereira C.S., Kelbert M., Daronch N.A., Michels C., de Oliveira D., Soares H.M., 2020. Potential of enzymatic process as an innovative technology to remove anticancer drugs in wastewater Appl. Microbiol. Biotechnol. 104, 23-31. https://doi. org/10.1007/s00253-019-10229-y.

Petit M., Curti Ch., Roche M., Montana M., Charleric B., Vanelle P., 2017. Environmental monitoring by surface sampling for cytotoxics: a review. Environ. Monit. Assess. 189(2). doi:10.1007/s10661-016-5762-9.

Rouches E., Herpoël-Gimbert I., Steyer J.P., Carrere H., 2016. Improvement of anaerobic degradation by white-rot fungi pretreatment of lignocellulosic biomass: A review. Renewable and Sustainable Energy Rev. 59, 179-198. doi:10.1016/j.rser.2015.12.317.

Russo C., Lavorgna M., Česen M., Kosjek T., Heath E., Isidori M., 2018. Evaluation of acute and chronic ecotoxicity of cyclophosphamide, ifosfamide, their metabolites/transformation products and UV treated samples. Environ. Poll. 233, 356-363. doi:10.1016/j.envpol.2017.10.066.

Rybczyńska-Tkaczyk K., Korniłłowicz-Kowalska T., Szychowski, K.A., 2021. Possibility to Biotransform Anthracyclines by Peroxidases Produced by Bjerkandera adusta CCBAS 930 with Reduction of Geno-and Cytotoxicity and Pro-Oxidative Activity. Molecules 26(2), 462. https://doi.org/10.3390/molecules26020462.

Santos M.S.F., Franquet-Griell H., Alves A., Lacorte S., 2018. Development of an analytical methodology for the analysis of priority cytostatics in water. Sci. Total Environ. 645, 1264-1272. doi:10.1016/j.scitotenv.2018.07.232. 
Santos M.S.F., Franquet-Griell H., Lacorte S., Madeira L.M., Alves A., 2017. Anticancer drugs in Portuguese surface waters - Estimation of concentrations and identification of potentially priority drugs. Chemosphere 184, 1250-1260. doi:10.1016/j.chemosphere.2017.06.102.

Siedlecka E.M., Ofiarska A., Borzyszkowska A.F., Białk-Bielińska A., Stepnowski P., Pieczyńska A., 2018. Cytostatic drug removal using electrochemical oxidation with BDD electrode: Degradation pathway and toxicity. Water Res. 144, 235-245. doi:10.1016/j.watres.2018.07.035.

Załęska-Radziwiłł M., Łebkowska M., Affek K., Zarzeczna A., 2011. Environmental risk assessment of selected pharmaceuticals present in surface waters in relation to cyanobacteria and plants. Ochr. Śr. Zasobów Nat. 48, 372-382.

Zounková R., Odráška P., Doležalová L., Hilscherová K., Maršálek B., Bláha L., 2007. Ecotoxicity and genotoxicity assessment of cytostatic pharmaceuticals. Environ. Toxicol. Chem. 26(10), 2208. doi:10.1897/07-137r. 
Wiktoria Polit ${ }^{1,3}$, Wojciech Ospałek ${ }^{1,4}$, Nina Mickiewicz ${ }^{1,5}$, Agata Satowska ${ }^{1,6}$, Agata Domagała ${ }^{1,7}$, Łukasz Wlazło ${ }^{2}$, Bożena Nowakowicz-Dębek ${ }^{2}$

\section{Wpływ ekspozycji na dźwięk na wzrost i rozmnażanie drożdży}

Effects of sound exposition on yeast growth and proliferation

Wpływ dźwięku na nasze życie jest niezaprzeczalny. Powstało wiele prac na temat jego działania na ludzką psychikę, w obrębie zainteresowań naukowców znalazły się również zwierzęta i rośliny. Wielorakie badania potwierdzają, że pewne zróżnicowane zakresy dźwięku oddziałują w różny sposób na wymienione organizmy. Wpływ fal akustycznych na mikroorganizmy jest jednak niszowym zagadnieniem w polskiej literaturze, do tej pory badania koncentrują się raczej na wpływie hałasu na komfort pracy oraz możliwości wykorzystania muzyki w motywowaniu i wspomaganiu ludzkiej psychiki.

Różne organizmy używają dźwięków do komunikacji i orientacji w przestrzeni, a ludzie również dla przyjemności. Nie można jednak zapomnieć, że fale akustyczne działają nie tylko na receptory odpowiadające za słyszenie, ale na wszystkie komórki organizmu, ich metabolizm i funkcjonowanie. Prace na temat reakcji ludzi oraz zwierząt, a nawet roślin [Gagliano i in. 2014] i bakterii [Norris i Hylan 1997, Matsuhashi i in. 1998], na usłyszane dźwięki są niezwykle fascynujące.

\section{Fizyka dźwięku}

Do świadomego badania dźwięków i ich wpływu niezbędna jest wiedza o ich pochodzeniu i właściwościach. W najbardziej skrótowej definicji dźwięk to wrażenie słuchowe spowodowane falą akustyczną rozchodzącą się w ośrodku sprężystym. Falę akustyczną w ujęciu fizycznym opisuje się jako zaburzenie gęstości i ciśnienia rozchodzące się w ośrodku w postaci fali podłużnej, któremu towarzyszą drgania cząsteczek ośrodka. Zaburzenie ciśnienia powoduje przenoszenie energii mechanicznej przez drgające cząsteczki właściwie bez zmiany ich położenia. Tworzy się fala, którą charakteryzuje okres, czyli czas wykonania jednego pełnego drgania, i amplituda, czyli największe wychylenie z położenia równowagi. Fala ma również swoją długość, czyli najmniejszą odległość między dwoma powtarzającymi się fragmentami fali. Wszystkie te parametry

${ }^{1}$ Uniwersytet Przyrodniczy w Lublinie, Wydział Biologii Nauk O Zwierzętach i Biogospodarki, Studenckie Koło Naukowe Nauk o Zwierzętach i Biogospodarki

${ }^{2}$ Uniwersytet Przyrodniczy w Lublinie, Wydział Biologii Nauk o Zwierzętach i Biogospodarki, Katedra Higieny Zwierząt i Zagrożeń Środowiska

${ }^{3}$ wiktoria.polit@o2.p1

${ }^{4}$ wojciecho.poczta@gmail.com

${ }^{5}$ nina.mickiewicz1@gmail.com

6ragata.satowska@onet.pl

7 agataxdomagala@gmail.com 
składają się na właściwości konkretnego dźwięku, czy też całego ich zestawu [Casati i Dokic 2010].

Dwa główne parametry opisujące dźwięk to jego częstotliwość i natężenie. Częstotliwość to wielkość fizyczna określająca liczbę cykli zjawiska w określonym czasie. Jej jednostką jest herc [Hz], odpowiadający wystąpieniu jednego cyklu w czasie 1 sekundy. Zależy od niej wysokość dźwięku - im większa częstotliwość fali, tym wyższy dźwięk. Częstotliwości słyszalne dla człowieka zawierają się w paśmie między wartościami granicznymi od ok. $16 \mathrm{~Hz}$ do ok. $20 \mathrm{kHz}$. Dźwięki o częstotliwości mniejszej niż $16 \mathrm{~Hz}$ są nazywane infradźwiękami, a te o częstotliwości powyżej $20000 \mathrm{~Hz}$ ultradźwiękami. Oczywiście niezmienny pozostaje fakt, że fale akustyczne mają wpływ na organizmy niezależnie od tego, czy te organizmy je słyszą, czy nie - hałas infra- i ultradźwiękowy tworzą jedno $z$ realnych zagrożeń współczesnego świata, a ultradźwięki mają od lat szerokie zastosowanie w medycynie ludzkiej i zwierzęcej [Szczeniowski 1990, Casati i Dokic 2010].

Natężenie to z kolei miara energii fali akustycznej równa średniej wartości strumienia energii akustycznej przepływającego w jednostce czasu (1 s) przez jednostkowe pole powierzchni $\left(1 \mathrm{~m}^{2}\right)$ zorientowanej prostopadle do kierunku rozchodzenia się fali. $\mathrm{W}$ układzie SI jednostką natężenia dźwięku jest $\mathrm{W} / \mathrm{m}^{2}$ (Wat na $\mathrm{m}^{2}$ ). Bardziej znany wszystkim decybel to wielkość opisująca poziom natężenia dźwięku, a w ujęciu matematycznym logarytm natężenia. W uproszczeniu można by przyjąć, że natężenie określa głośność dźwięku [Everest 2004].

Fale wchodzą w reakcje ze sobą nawzajem. Jedną $\mathrm{z}$ tych interakcji jest interferencja fal, która polega na dodawaniu dwóch lub więcej fal, czego rezultatem jest pewna fala wypadkowa o tej samej częstotliwości. Interakcje te mają szczególne znaczenie w badaniu wpływu muzyki na organizmy, gdyż jest ona niczym innym niż zbiorem fal akustycznych.

Przypuszcza się, że biologiczny efekt działania dźwięku na mikroorganizmy hodowane w płynnych podłożach jest powodowany ciśnieniem akustycznym, czyli odchyleniem od lokalnego ciśnienia spowodowanym przez falę dźwiękową [Everest 2004, Jomdecha i Cherdpong 2006].

\section{Wpływ dźwięku na rośliny i zwierzęta}

Pozytywny wpływ muzyki na wzrost roślin udowodniono już w 1965 r. Rośliny $\mathrm{z}$ rodzaju niecierpkowatych poddane działaniu fal akustycznych rosły o $20 \%$ szybciej w górę, a przyrost ich biomasy był zwiększony aż o 71\% w stosunku do grupy kontrolnej [Singh 1965]. Od tamtego czasu badania te były powtarzane przez wielu naukowców, m.in. w China Agricultural University udowodniono, że ekspozycja na dźwięk zwiększa plony oraz zwiększa odporność roślin na mszyce i grzyby. Godzinne działanie fal akustycznych o częstotliwości $1 \mathrm{kHz}$ i natężeniu $100 \mathrm{~dB}$ powodowało wyraźny wzrost aktywności enzymów ochronnych i endogennych hormonów, większą plastyczność ściany komórkowej kalusa oraz przyspieszało podziały komórkowe w obrębie tej tkanki. Odnotowano podniesiony poziom aktywności ATP-azy w błonie plazmatycznej i amylazy kalusa, zwiększona była również zawartość rozpuszczalnych cukrów i białek. Ponadto stwierdzono, że procesy transkrypcji zachodzą szybciej, a zawartość RNA w komórce jest wyższa u roślin poddanych działaniu dźwięku. Z kolei użycie technologii akustycznej (ang. plant acoustic frequency technology, PAFT) przez 3 godziny 
zwiększyło plony papryki o 30,05\%, ogórków o 37,1\% i pomidorów o $13,2 \%$, plony pozostałych badanych roślin również uległy znacznemu zwiększeniu. W hodowli pomidorów szklarniowych zaobserwowano spadek występowania mszyc, przędziorka, szarej pleśni i chorób wirusowych [Hassanien i in. 2014]. Wyżej opisane dane wyraźnie potwierdzają oddziaływanie fal akustycznych na metabolizm i fizjologię roślin.

Badania nad wpływem dźwięków na żywe organizmy są też prowadzone pod kątem dobrostanu zwierząt. W 2016 r. opublikowano wyniki badań nad wpływem chronicznego hałasu na metabolizm glukozy i stan zapalny jelita powodowany mikroflorą gospodarza u szczurów. Okazuje się, że ekspozycja na hałas przez 30 dni, wywołuje efekty trwające nawet 14 dni po jego zaprzestaniu. Hałas powoduje zmniejszenie liczebności bakterii probiotycznych jelita i wzrost flory patologicznej oraz zaburzenia w gospodarce cukrami [Bo Cui i in. 2016]. Ponadto ekspozycja na ultradźwięki o natężeniu $122 \mathrm{~dB}$ powoduje u zwierząt laboratoryjnych perturbacje w parametrach fizjologicznych, np. tętna czy ciśnienia, a nawet wady w rozwoju płodowym [Motzel 2003].

W 2018 r. opublikowano wyniki badań przeprowadzonych na myszach pod kątem zwiększenia ryzyka wystąpienia choroby Alzhaimera po długotrwałej ekspozycji na hałas. Oprócz potwierdzenia powyższej tezy badania te wykazały również spadek różnorodności flory bakteryjnej jelit [Bo Cui i in. 2018].

Powszechnie znanym faktem jest pozytywny wpływ muzyki klasycznej na dobrostan zwierząt gospodarskich. Coraz popularniejszą praktyką staje się puszczanie muzyki w pomieszczeniach, w których przebywają zwierzęta, w szczególności bydło mleczne. Zanotowano wyraźną pozytywną korelację pomiędzy ekspozycją na dźwięki muzyki klasycznej a wzrostem mleczności [Projekt Agar 2019].

\section{Wpływ dźwięku na drożdże}

Zarówno prokariotyczne, jak i eukariotyczne organizmy jednokomórkowe są wrażliwe na oddziaływanie muzyki, co może wpływać na ich aktywność i przeżywalność [Mortazavian 2012]. Prowadzone wcześniej badania własne wykazały, że rozwój drożdży zachodzi szybciej przy stymulacji muzyką klasyczną - wybranymi utworami Fryderyka Chopina. Koncentracja komórek drożdży była niemal czterokrotnie wyższa $\mathrm{w}$ próbie poddanej działaniu dźwięku w porównaniu z próbą kontrolną inkubowaną w ciszy [Polit i in. 2019].

W innych badaniach potwierdzono wpływ różnego rodzaju stymulacji dźwiękowej na wzrost oraz czynność metaboliczną drożdży. Próby Saccharomyces cerevisae inkubowane w płynnym podłożu poddano działaniu trzech różnych zakresów fal akustycznych - fal o niskiej częstotliwości, fal o wysokiej częstotliwości oraz fal o zróżnicowanej częstotliwości w formie muzyki. Wyniki porównano z próbą kontrolną inkubowaną w ciszy. Wykazano, że przy działaniu dźwięku faza pierwotnego zahamowania wzrostu bakterii jest wydłużona o mniej więcej godzinę, natomiast faza wykładniczego wzrostu skrócona o dwie. Ponadto drożdże w próbie z muzyką wykazywały tempo rozmnażania $12,4 \%$ wyższe niż te w próbie kontrolnej, a zarówno wysokie, jak i niskie częstotliwości znacząco je przyspieszały. Redukcji uległa jednakże produkcja biomasy do $14 \%$ w porównaniu $\mathrm{z}$ drożdżami inkubowanymi w ciszy. Po oznaczeniu jakościowym i ilościowym 55 metabolitów biorących udział w głównych szlakach metabolicznych wykazano znaczne różnice pomiędzy wszystkimi próbami. $32 \mathrm{z}$ nich miało inne stężenie $\mathrm{w}$ zależności od rodzaju stymulacji, a 9 było specyficznych dla konkretnych warunków inkubacji. 
Stężenie części z oznaczonych we wszystkich próbach metabolitów liniowo spadało od próby inkubowanej w warunkach ciszy, poprzez muzykę, niskie i wysokie częstotliwości np. ornityna, glutamina. Z drugiej strony kilka metabolitów wykryto tylko w konkretnych próbach - w próbach poddanych działaniu fal akustycznych o wysokiej i niskiej częstotliwości oznaczono np. $\mathrm{NADP}^{+}, \mathrm{NAD}^{+}$, kwas jabłkowy czy kwas fumarowy; w próbie z muzyką - norwalinę, a w warunkach ciszy między innymi - ang. norleucine. Wyżej wymienione dane wskazują na korelację pomiędzy częstotliwością dźwięku a różną odpowiedzią metaboliczną i fizjologiczną drożdży [Bastos Mereschi Aggio i in. 2012]. Zastosowanie ultradźwięków w postaci fali akustycznej rozchodzącej się w ośrodku oraz fali stojącej o częstotliwości niewiele ponad $2 \mathrm{MHz}$ nie zabiło badanych komórek drożdży, jednakże widoczne były różne zmiany morfologiczne w zależności od użytego rodzaju fali [Guerrero i in. 2001].

Wpływ wysokich częstotliwości, a konkretnie ultradźwięków o częstotliwości $20 \mathrm{kHz}$, został zbadany na drożdżach Saccharomyces cerevisae pod kątem ich tempa rozmnażania oraz przeprowadzanego przez nie procesu fermentacji. Do eksperymentu użyto dwóch prób, jedna z nich była inkubowana w zwykłych warunkach, a drugą wstrząsano z siłą $100 \mathrm{rpm}$. Druga próba kontrolna ma związek z techniką używaną w przemyśle spożywczym przy tworzeniu biostarterów dla procesu fermentacji. Następnie oba warianty poddano działaniu ultradźwięków o różnym natężeniu. Uzyskane pomiarami spektrofotometrycznymi wyniki wykazały, że stymulacja wysokimi częstotliwościami o natężeniu $0,8 \mathrm{~W} / \mathrm{m}^{2}$ obniża tempo rozmnażania $\mathrm{W}$ fazie pierwotnego zahamowania wzrostu, natomiast ostatecznie przyspiesza tempo rozmnażania w fazie wykładniczego wzrostu i utrzymuje się na wyższym poziomie w porównaniu $\mathrm{z}$ obiema próbami kontrolnymi. Próby drożdży $z$ użyciem ultradźwięków o natężeniu 0,2 oraz $0,4 \mathrm{~W} / \mathrm{m}^{2}$ również wykazywały podobne reakcje, chociaż odchylenia od próby inkubowanej bez czynnika badanego nie były znaczne [Jomdecha i Cherdpong 2006].

\section{Wpływ muzyki na inne mikroorganizmy}

Badania prowadzone na mikroorganizmach innych niż grzyby zdają się potwierdzać ogólną tezę, że fale akustyczne zarówno te słyszalne, jak i niesłyszalne mają wpływ na metabolizm i fizjologię organizmów jednokomórkowych.

Oddziaływanie muzyki indyjskiej o szerokim spektrum częstotliwości $(38-689 \mathrm{~Hz})$ wykazało pozytywny wpływ na rozwój zarówno badanych drożdży, jak i bakterii, z wyjątkiem Serratia marcescens. Potwierdzono również udział muzyki jako czynnika zmieniającego produkcję metabolitów, a nawet wrażliwość na antybiotyki badanych organizmów. Bakteria Chromobacterium violaceum oraz drożdże $S$. marcescens pod wpływem muzyki szybciej rozkładają cefazolinę. Ponadto przypuszcza się, że stymulacja falami akustycznymi zmienia przepuszczalność błony komórkowej, gdyż stężenia wapnia, potasu oraz zawartość białek w próbach badawczych różnią się znacznie od prób inkubowanych w standardowych warunkach. [Niral i Vijay 2015].

Kolejne badania uwzględniające wpływ indyjskiej muzyki, tym razem o zakresie częstotliwości 41-645 Hz, wykazały podobne wyniki. Dokładniejsze analizy wykazały, że zwiększenie produkcji pewnych związków, a mianowicie prodigiozyny, wiolaceiny, EPS oraz alkoholu, było znaczniejsze niż wzrost samego tempa rozmnażania. Z wyjątkiem $S$. marcescens u wszystkich organizmów poddanych działaniu muzyki zarejestrowano zwiększoną podatność na zastosowany antybiotyk. Dzięki zmierzeniu zewnątrz- 
komórkowego stężenia antybiotyku w płynnym podłożu wykazano, że stężenie to było mniejsze w przypadku prób poddanych działaniu muzyki w porównaniu z próbą kontrolną, co wskazuje na większy stopień pochłaniania antybiotyku przez komórki stymulowane dźwiękowo. Co więcej procent zwiększonego wchłaniania antybiotyku był większy niż procent zwiększania tempa rozmnażania, co oznacza, że mniejsze zewnątrzkomórkowe stężenie antybiotyku nie zależało wyłącznie od większego zagęszczenia mikroorganizmów w badanych próbach [Niral i Vijay 2017].

Działanie fal akustycznych na Escherichia coli stwierdzono eksperymentalnie dla dwóch częstotliwości $432 \mathrm{~Hz}$ oraz $4 \mathrm{kHz}$. Przy niższej częstotliwości zarejestrowano szybsze tempo wzrostu i większą podatność na zastosowany antybiotyk niż w próbie kontrolnej. Jednak pod wpływem $4 \mathrm{kHz}$ wzrost był znacznie zahamowany, a strefa zahamowania wzrostu była nieznacznie mniejsza w stosunku do kontroli [Souvik i in. 2018].

Wykazano znacznie mniejszą liczbę kolonii Staphylococcus aureus w hodowlach płynnych poddanych działaniu dźwięku o niskim natężeniu $\left(3-161 \mathrm{~mW} / \mathrm{cm}^{2}\right)$ i częstotliwości $1,5 \mathrm{mHz}$ w porównaniu z próbą inkubowaną w warunkach ciszy. Nie stwierdzono natomiast zmian we wrażliwości na zastosowane antybiotyki oraz zmian w genomie. Jednakże w próbach, na które działano ultradźwiękami, zauważono zniszczenia i dezintegrację ściany komórkowej, chociaż grubość tejże była statystycznie większa [Ayan i in. 2008].

W 2018 r. przeprowadzono badania, które potwierdziły pozytywny wpływ dźwięku na germinację endospor laseczki Bacillus atrophaeus. Formy przetrwalnikowe wspomnianej bakterii oraz Bacillus subtilis poddano stymulacji falami akustycznymi o częstotliwości $5 \mathrm{kHz}$ i natężeniu $90 \mathrm{~dB}$. Oznaczenie fluorescencyjne wykazało, że tempo kiełkowania spor dla $B$. atrophaeus było o około $40 \%$, a ostateczny poziom germinacji o około $60 \%$ wyższy. Podobnych reakcji nie zaobserwowano u endospor B. subtilis, aczkolwiek autorzy przypuszczają, że wynika to $\mathrm{z}$ różnic $\mathrm{w}$ budowie spor tych gatunków, co zmienia stopień absorpcji dźwięku. Oddziaływanie fal akustycznych zbadano również na morskim szczepie bakterii Brevibacterium sp. Produkuje ona żółty pigment, którego zawartość zmierzono ilościowo obok tempa namnażania bakterii. W doświadczeniu zastosowano dwa słynne utwory z filmów Tollywood o natężeniu 60-90 dB, w których częstotliwości przeważnie wahały się pomiędzy 100 i $1000 \mathrm{~Hz}$. Bakterie poddane działaniu muzyki wykazywały szybsze tempo namnażania w porównaniu z próbą kontrolną. Biomasa prób doświadczalnych była od 2,8 do 3,5 raza wyższa. Również produkcja pigmentu uległa zwiększeniu pod wpływem dźwięku [Sharath Chandra i in. 2018].

W świetle omówionych wyników oczywistym zdaje się fakt, że wiedza z zakresu wpływu dźwięku na funkcjonowanie i metabolizm mikroorganizmów ma istotne znaczenie i może okazać się przydatna w wielu branżach, poczynając od przemysłu spożywczego, a kończąc na medycynie.

\section{Bibliografia}

Ayan I., Aslan G., Cömelekoğlu U., Yilmaz N., Colak M., 2008. The effect of low intensity pulsed sound waves delivered by the exogen device on Staphylococcus aureus morphology and genetics. Acta Orthop. Traumatol. Turc. 42(4), 272-277.

Bastos Mereschi Aggio R., Obolonkin V., Granato Villas-Bôas S., 2012 Sonic vibration affects the metabolism of yeast cells growing in liquid culture: a metabolomic study Metabolomics 8 , $670-678$. 
Bo Cui, Zhihui Gai, Xiaojun She, Rui Wang, Zhuge Xi, 2016. Effects of chronic noise on glucose metabolism and gut microbiota-host inflammatory homeostasis in rats. Scient. Rep., vol. 6, Article number: 36693.

Bo Cui, Donghong Su, Wenlong Li, Xiaojun She, Ming Zhang, Rui Wang, Qingfeng Zhai, 2018. Effects of chronic noise exposure on the microbiome-gut-brain axis in senescence-accelerated prone mice: implications for Alzheimer's disease. J. Neuroinflammation 15, Article number: 190.

Casati R., Dokic J., Sounds, w: Stanford Encyclopedia of Philosophy [online], CSLI, Stanford University, 5 października 2010, ISSN 1095-5054 [dostęp 25.03.2020].

Everest F.A., 2004. Podręcznik akustyki. Katowice: Wyd. Sonia Draga.

Gagliano M., Renton M., Depczynski M. et al., 2014. Experience teaches plants to learn faster and forget slower in environments where it matters. Oecologia 175, 63-72.

Guerrero S., Lopez A., Alzamora S.M., 2001. Effect of ultrasound on the survival of Saccharomyces cerevisiae: influence of temperature, $\mathrm{pH}$ and amplitude. Innovat. Food Sci. Emerg. Technol. 2, 31-39.

Hassanien Reda He, Tian-zhen Hou, Yu-feng Li and Bao-ming Li, 2014. Advances in effects of sound waves on plants. J. Integrative Agric. 13, 2, 335-348.

Jomdecha C., Cherdpong A., 2006. The research of low-ultrasonic energy affects to yeast growth in fermentation process. $12^{\text {th }}$ A-PCNDT $2006-$ Asia-Pacific Conference on NDT, $5^{\text {th }}-10^{\text {th }}$ Nov 2006

Matsuhashi M., Pankrushina A.N., Takeuchi S., Ohshima H., Miyoi H., Endoh K. et al., 1998 Production of sound waves by bacterial cells and the response of bacterial cells to sound. J. Gen. Appl. Microbiol. 44(1), 49-55.

Mortazavian A.M., 2012. Music affects survival and activity of microorganisms. J. Paramed. Sci. 3.

Motzel Sh. L. Breakout Session: Effects of Sound on Research Animals. The Development of Science-based Guidelines for Laboratory Animal Care: Proceedings of the November 2003 International Workshop.

Niral Sarvaiya, Vijay Kothari, 2015. Effect of audible sound in form of music on microbial growth and production of certain important metabolites. Microbiology 84(2), 227-235.

Niral Sarvaiya, Vijay Kothari, 2017. Audible sound in form of music can influenc microbial growth, metabolism and antibiotic susceptibility. J. Appl. Biotechnol. Bioeng. 2, 6.

Norris V., Hyland G.J., 1997. Do bacteria sing? Sonic intercellular communication between bacteria may reflect electromagnetic intracellular communication involving coherent collective vibrational modes that could integrate enzyme activities and gene expression. Mol. Microbiol. 24, 879-980.

Polit W., Mickiewicz N., Ospałek W., Satowska A., Kuca D., Ossowski M., 2019. Wpływ ekspozycji na dźwięk na wzrost i rozmnażanie mikroorganizmów, Ref. na XVI Międzynarodowym Sem. Studenckich Kół Naukowych „Środowisko - Zwierzę - Produkt”.

Projekt Agar. Masz już playlistę do obory? Sprawdź jakiej muzyki słuchają krowy. 2019 https://projektagrar.pl/jaki-jest-wplyw-muzyki-na-krowy/ [dostęp 17.03.2020].

Sharath Chandra T., Sri Lekha V., Murali Krishna T., 2018. Effect of music on growth and pigment production of Brevibacterium sp. Intern. J. Pharm. Chemical Biol. Sci. 8(1), 157-160.

Singh T.C.N. 1965. On the growth and tillering in paddy variety Patambi under the irradiation of musical sound. J. Annamalai Univ. 26, 100-103.

Souvik Banerjee, Abhishek Goswami, Ananya Datta, Anish Pyne, Anjoom Nikhat, Bodhisattwa Ghosh 2018. Effect of Different Sound Frequencies on the Growth and Antibiotic Susceptibility of Escherichia coli. Int. J. Curr. Microbiol. App. Sci. 7(3).

Szczeniowski S,, 1980. Fizyka doświadczalna. Mechanika i akustyka, PWN, Warszawa. 
Karolina Spólna ${ }^{1,2}$, Sonia Pustelny ${ }^{1}$

\section{Czy hybrydyzacja może być realnym zagrożeniem dla funkcjonowania populacji wierzby lapońskiej (Salix lapponum L.) na torfowiskach Pojezierza Łęczyńsko-Włodawskiego?}

Can hybridization be a real threat to the functioning of the Salix lapponum populations in the bogs of the Łęczyńsko-Włodawskie Lakeland?

Rodzina wierzbowate (Salicaceae) obejmuje ponad 50 rodzajów oraz około 1200 gatunków roślin związanych głównie ze strefą klimatu umiarkowanego półkuli północnej. Wierzbowate to rośliny zwykle dwupienne o kwiatach wiatro- lub owadopylnych pozbawionych okwiatu. Kwiaty są zebrane w gęste kwiatostany i zakwitają zazwyczaj przed rozwojem liści lub wraz z tym rozwojem. Owoc roślin z rodzaju Salix stanowi mała, sucha, wielonasienna torebka, zawierająca liczne nasiona, opatrzone dużą ilością białego, lotnego puchu. U większości gatunków owoce uwalniają krótkożywotne nasiona wczesną wiosną, w maju lub czerwcu [Rutkowski 1998].

W Polsce swoje granice zasięgu mają dwa gatunki wierzb uznawane za reliktowe: wierzba lapońska (Salix lapponum L.) oraz wierzba borówkolistna (S. myrtilloides L.) [Kaźmierczakowa i in. 2014].

Salix lapponum jest gatunkiem, którego zasięg naturalnego występowania obejmuje północną i północno-wschodnią Europę oraz zachodnią Syberię. Występuje także na oderwanych stanowiskach $\mathrm{w}$ górach środkowej i południowej Europy. W Polsce przebiega południowo-zachodnia granica występowania gatunku. W naszym kraju zanotowano ponad 60 stanowisk wierzby lapońskiej, lecz większość z nich jest już historyczna. Potwierdzone zostały stanowiska głównie w Puszczy Knyszyńskiej oraz w Poleskim Parku Narodowym.

Wierzba lapońska w Polsce rośnie w siedliskach torfowiskowych (na torfowiskach niskich i przejściowych) na terenach nizinnych oraz w górach na wysokości około $1400 \mathrm{~m}$ n.p.m., gdzie tworzy charakterystyczny zespół Salicetum lapponum. Zwykle występuje pojedynczo lub w małych skupiskach, rzadziej tworzy zarośla. Preferuje siedliska częściowo ocienione lub umiarkowanie nasłonecznione, o dużej wilgotności, kwaśnym odczynie podłoża [Zarzycki i in. 2003, Kaźmierczakowa i in. 2014, Serafin i in. 2015, Piękoś-Mirkowa i Mirek 2018]. S. lapponum jest objęta w Polsce ochroną prawną, a od 2014 r. posiada status gatunku krytycznie zagrożonego [Kaźmierczakowa i in. 2014].

Wierzba lapońska to niewielki krzew o wysokości około $1 \mathrm{~m}$. Okazy wyższe (do około $2 \mathrm{~m}$ ) spotykane są w fitocenozach zdominowanych przez gatunki roślin drzewiastych i krzewiastych, które wymuszają konkurencję o światło. Młode gałązi S. lapponum są srebrzyście owłosione, $\mathrm{z}$ wiekiem łysieją i wybarwiają się na brunatno. Liście tego

\footnotetext{
${ }^{1}$ Uniwersytet Przyrodniczy w Lublinie, Wydział Biologii Środowiskowej, Studenckie Koło Naukowe Ekologów

${ }^{2}$ karolina21248@gmail.com
} 
gatunku są z wierzchu szarozielone, a od spodu kutnerowato owłosione, mają kształt eliptyczny, są całobrzegie, długości około $3,5 \mathrm{~cm}$ i szerokości średnio 2,5 cm (ryc. 1). Wierzba lapońska na terenie swojego zwartego zasięgu występowania kwitnie od maja do lipca. W oderwanych stanowiskach oraz na terenach, gdzie osiąga południową granicę swojego zasięgu, kwiatostany pojawiają się już bardzo wczesną wiosną (w marcu i kwietniu). Męskie kotki (długości około 2,5 cm) są znacznie krótsze od żeńskich (do $9 \mathrm{~cm}$ ). Męski kwiat posiada jeden gruczoł miodnikowy. Żeńskie kotki są wielokwiatowe, gęsto owłosione. Wierzba lapońska jest krzewem dwupiennym. S. lapponum L. jest gatunkiem ambofilnym co oznacza, że jej pyłek może być przenoszony zarówno przez wiatr, jak i owady [Bolliger i in. 1998, Hroneš 2018, Piękoś-Mirkowa i Mirek 2018]. Dane literaturowe mówią o tym, że wierzba ta w warunkach Polski rozmnaża się głównie wegetatywnie [Kaźmierczakowa i in. 2014]. Badania przeprowadzone w ostatnim czasie nad populacjami $S$. lapponum na Polesiu Lubelskim wskazują jednak na brak klonów w populacjach, co świadczy o tym, że osobniki pochodzą wyłącznie z rozmnażania płciowego [Pogorzelec i in. 2015, Głębocka i Pogorzelec 2017].

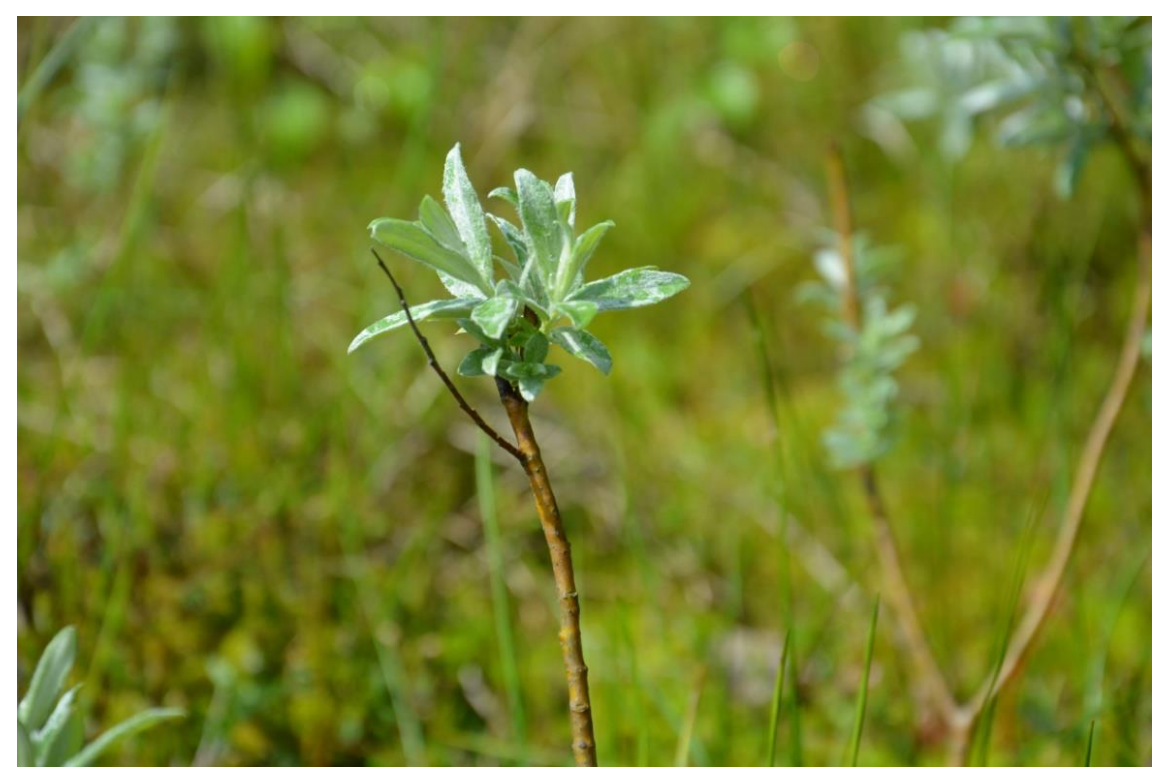

Ryc. 1. Pęd wierzby lapońskiej (fot. M. Pogorzelec)

Wierzba lapońska jest gatunkiem, który może ulegać hybrydyzacji przez krzyżowanie się z innymi gatunkami wierzb (np. Salix cinerea, S. aurita, S. rosmarinifolia, S. myrtilloides) współwystępującymi w fitocenozach [Hroneš 2018]. Mieszańce i hybrydyzacja międzygatunkowa nie są rzadkie w świecie roślin. Hybrydą nazywamy osobnika, który jest potomkiem dwóch lub większej ilości osobników różnych gatunków. Hybrydy zwykle wykazują podobieństwo fenotypowe do rodziców, ale zdarza się, że osobnik potomny posiada znacznie więcej cech jednego z rodziców, co utrudnia jego klasyfikację do konkretnego gatunku. Mieszańce międzygatunkowe charakteryzują się zróżnicowanym stopniem płodności, od całkowicie bezpłodnych po tak płodne jak gatunki rodzicielskie. Zdolne do rozmnażania płciowego hybrydy mogą dalej krzyżować 
się z osobnikami innych taksonów, co może prowadzić do powstawania hybryd wielogatunkowych. Wiele mieszkańców obumiera we wczesnych stadiach rozwoju lub są niezdolne do wytworzenia kwiatów. Konsekwencją hybrydyzacji może być powstanie roju mieszańców, które zacierają granice między dwoma gatunkami. Zdarza się, że mieszańce wypierają ,,czyste” formy gatunków, z których pochodzą. Pomimo występowania w bliskim sąsiedztwie gatunków zdolnych do krzyżowania się ze sobą nie zawsze obserwuje się powstawanie hybryd. Wynika to z istnienia mechanizmów izolacyjnych, które uniemożliwiają powstawanie mieszańców. Izolacją sezonową (fenologiczną) nazywamy sytuację, w której dwa gatunki występują w tym samym miejscu, ale kwitną W różnych terminach [Stace 1993].

Celem pracy była próba zweryfikowania możliwości występowania zagrożenia hybrydyzacją gatunku rzadkiego i chronionego - wierzby lapońskiej (Salix lapponum L.) na podstawie analizy wybranych aspektów biologii kwitnienia roślin z rodziny Salicaceae, współwystępujących w stanowisku badanego gatunku na Pojezierzu Łęczyńsko-Włodawskim.

\section{Materiał i metody badań}

Przedmiotem badań prowadzonych w marcu i kwietniu 2019 r. były gametofity męskie dwóch gatunków z rodziny Salicaceae: zagrożonego ekstynkcją na terenie naszego kraju taksonu reliktowego Salix lapponum (wierzby lapońskiej) i gatunku rodzimego, szeroko rozpowszechnionego na terenie Polski - wierzby szarej (S. cinerea).

W pierwszym etapie prac przeprowadzono pobór prób ziaren pyłku obu gatunków, z osobników rosnących w ekosystemie torfowiskowym zlokalizowanym na zachodnim brzegu jeziora Bikcze (Pojezierze Łęczyńsko-Włodawskie). W dwóch terminach (T1 - 27.03.2019 r. i T2 - 02.04.2019 r.) pobrano dojrzałe kotki męskie z 6 losowo wybranych osobników S. lapponum (SL1 - SL6) i 4 osobników S. cinerea (SC1 - SC4) rosnących w bezpośrednim sąsiedztwie. Materiał przetransportowano w papierowych torbach do laboratorium (ryc. 2).

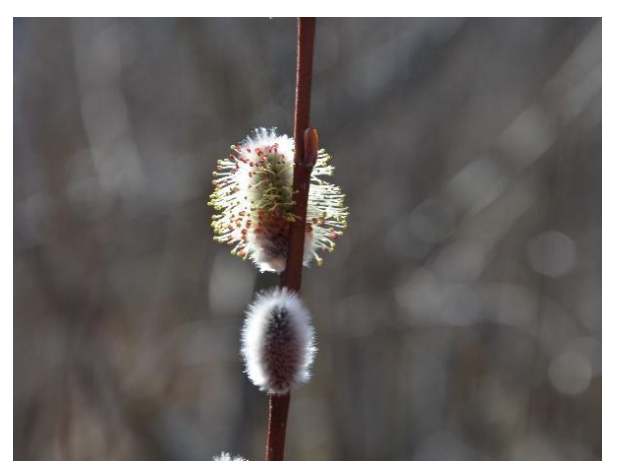

A

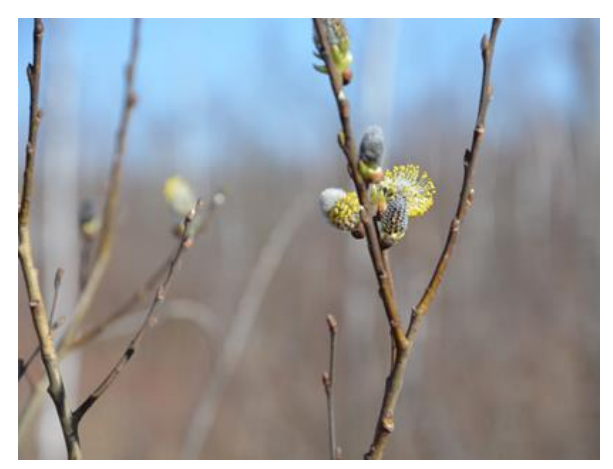

B

Ryc. 2. Kwiatostany męskie A - Salix lapponum; B - Salix cinerea (fot. M. Pogorzelec) 
Badania laboratoryjne przeprowadzono w dwóch etapach. W pierwszej części doświadczenia sprawdzono żywotność ziaren pyłku wierzby lapońskiej i wierzby szarej z wykorzystaniem acetokarminu (który barwi na czerwono żywe protoplasty komórek). Preparaty z zabarwionymi ziarnami pyłku oglądano po 1 godzinie od ich przygotowania, wykorzystując mikroskop świetlny. Zliczano po 1000 ziaren pyłku w każdym z preparatów, określając udział martwych i żywych gametofitów męskich.

Proces kiełkowania ziaren pyłku został przeprowadzony z użyciem 2,5\% oraz 5\% roztworu wodnego glukozy jako pożywki. W pojemnikach plastikowych o pojemności ok. $2 \mathrm{ml}$ za pomocą pipety laboratoryjnej umieszczono przygotowane wcześniej roztwory wodne glukozy. Następnie za pomocą igły preparacyjnej przeniesiono pobrany z kotków S. lapponum i S. cinerea pyłek i umieszczono go w roztworze. Pyłek S. lapponum umieszczono w 2,5\% roztworze glukozy wg zaleceń Pogorzelec i in. [2014], a pyłek $S$. cinerea w $2,5 \%$ i $5 \%$ roztworze wodnym glukozy, ze względu na brak wcześniejszych danych o optymalnych dla kiełkowania ziaren pyłku tego gatunku warunkach laboratoryjnych. Pojemniki zdeponowano w temperaturze pokojowej, bez dostępu światła. Po upływie 24 h przygotowywano preparaty mikroskopowe, pobierając roztwory z pyłkiem z każdego pojemnika. Liczono ziarna pyłku, które wykiełkowały w łagiewkę pyłkową w próbie 300 gametofitów męskich i ustalano \% udział zdolnych do kiełkowania w łagiewkę.

\section{Wyniki badań}

W próbie materiału roślinnego (T1) zabarwionego acetokarminem odnotowano 99\% żywych gametofitów męskich zarówno wierzby lapońskiej, jak i wierzby szarej. W próbie pobranej sześć dni później (T2) w przypadku wierzby lapońskiej 97\% protoplastów gametofitów męskich wybarwiło się na czerwono, a w przypadku wierzby szarej $99 \%$ (ryc. 3).

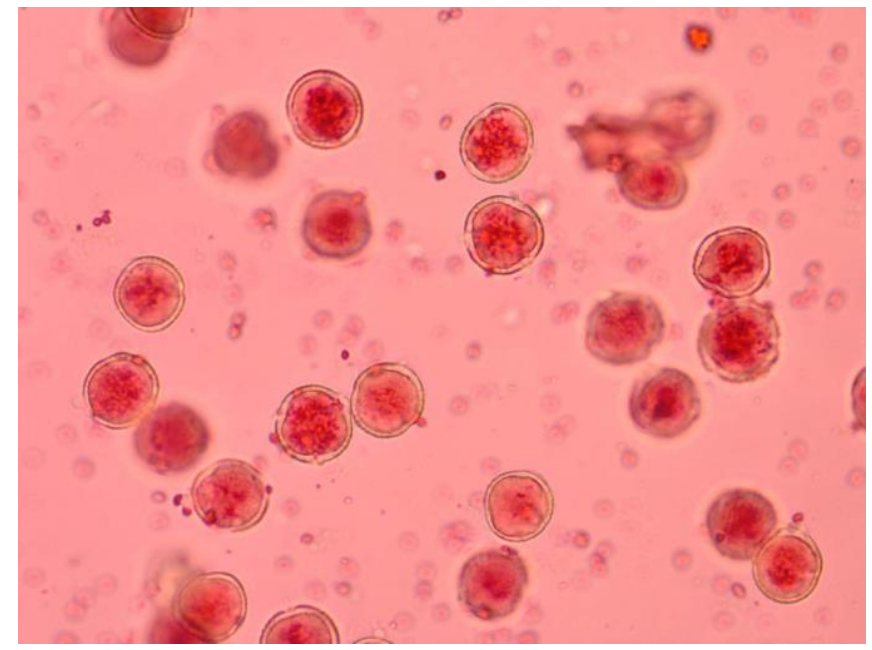

Ryc. 3. Ziarna pyłku wierzby lapońskiej po wybarwieniu acetokarminem (fot. M. Pogorzelec) 
Badanie żywotności ziaren pyłku (T1), określanej na podstawie zdolności ich kiełkowania w łagiewkę, w środowisku roztworu wodnego glukozy 2,5\% wykazało, że po upływie 24 h łagiewka pyłkowa była obecna w przypadku $50 \%$ (średnia ze wszystkich badanych prób) obserwowanych ziaren pyłku wierzby lapońskiej i $20 \%$ wierzby szarej. Badanie powtórzone $\mathrm{z}$ wykorzystaniem materiału roślinnego pobranego $\mathrm{w}$ drugim terminie (T2) wykazało, że po 24 h łagiewki pyłkowe odnotowano w $56 \%$ przypadków gametofitów męskich wierzby lapońskiej i 13\% wierzby szarej. Wyniki jednostkowe (dla poszczególnych osobników) były zróżnicowane w przypadku obu gatunków (ryc. 4).

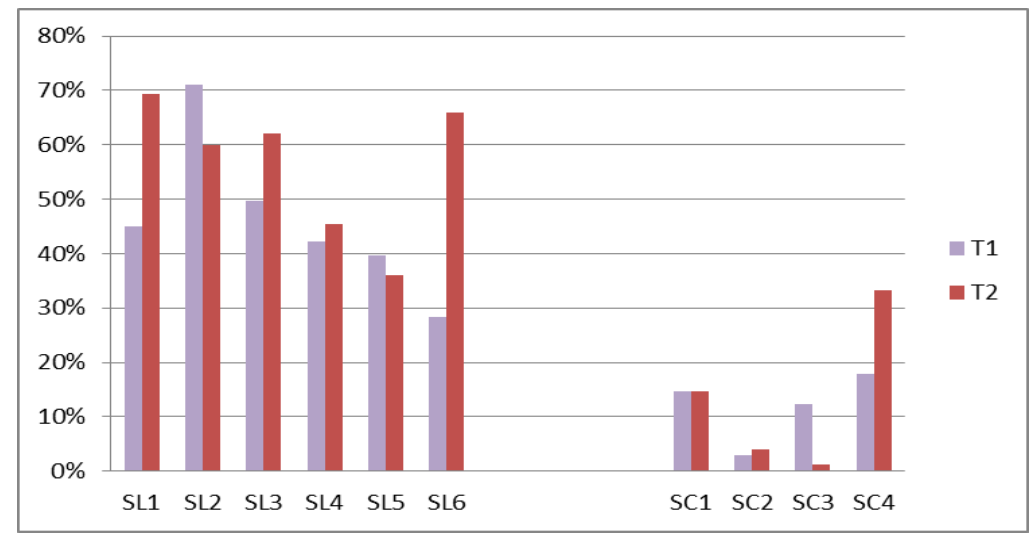

Ryc. 4. Procentowy udział ziaren pyłku Salix lapponum (SL1-SL6) i S. cinerea (SC1-SC4), które wytworzyły łagiewkę w 2,5\% roztworze glukozy, w dwóch terminach badań (T1 i T2)

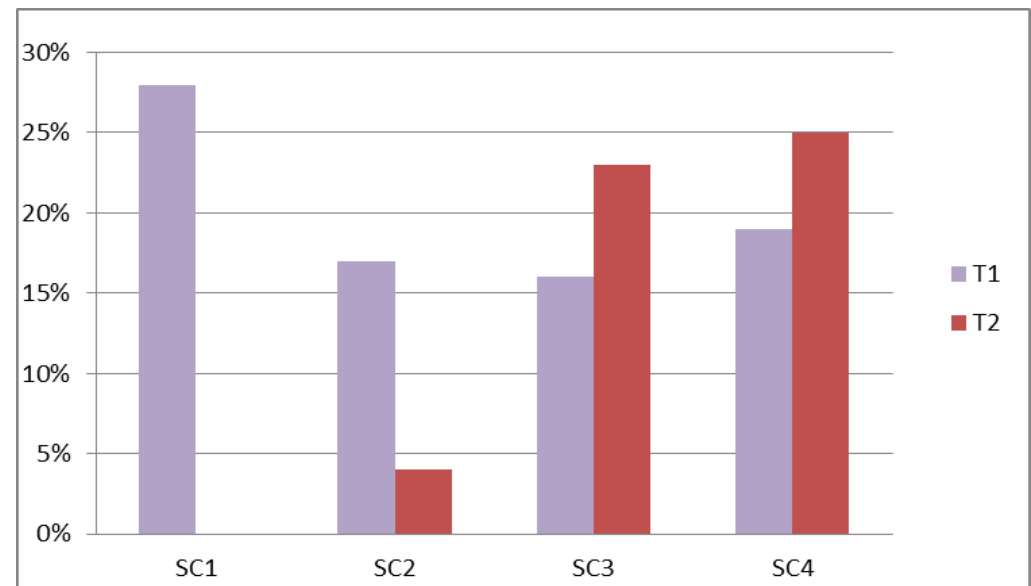

Ryc. 5. Procentowy udział kiełkujących w łagiewkę ziaren pyłku czterech osobników Salix cinerea (SC1-SC4), w 5\% roztworze glukozy (w dwóch terminach badań - T1 i T2)

Żywotność pyłku wierzby szarej była również określana po $24 \mathrm{~h}$ od umieszczeniu w 5\% roztworze wodnym glukozy. W przypadku materiału roślinnego pobranego w pierwszym terminie łagiewki pyłkowe wytworzyło średnio $12 \%$ gametofitów męskich $S$. cinerea, 
$13 \%$ ziaren pyłku pobranych w drugim terminie wykiełkowało w łagiewkę pyłkową po 24 h ekspozycji w pożywce. W przypadku jednego z badanych osobników (SC1) nie stwierdzono kiełkowania ziaren pyłku (ryc. 5).

\section{Dyskusja i wnioski}

Hybrydyzacja stanowi jedno z głównych zagrożeń dla zachowania tożsamości gatunkowej S. lapponum, szczególnie w ekosystemach, w których współwystępują z nią inne gatunki z rodzaju Salix. Porównanie wyników analiz żywotności pyłku S. lapponum i $S$. cinerea przeprowadzonych w 2019 r. (w dwóch terminach) nie wskazują jednoznacznie na możliwość krzyżowania się tych dwóch gatunków na badanym terenie ze względu na różnice w zdolności gametofitów do kiełkowania w łagiewkę pyłkową.

We wszystkich prowadzonych dotychczas analizach żywotności pyłków wierzby lapońskiej metodą barwienia acetokarminem wyniki potwierdzały obecność żywych protoplastów komórek gametofitów męskich w ponad 90\% [Dzwonkowski 2011, Pogorzelec i in. 2015]. Tożsame wyniki otrzymano w roku 2019, badając żywotność ziaren pyłku roślin pochodzących z tego samego stanowiska na torfowisku nad jeziorem Bikcze na Pojezierzu Łęczyńsko-Włodawskim. Równie wysoką żywotnością charakteryzowały się pyłki osobników $S$. cinerea współwystępujących w fitocenozie z S. lapponum, które były po raz pierwszy badane wspomnianą wcześniej metodą.

We wszystkich prowadzonych dotychczas obserwacjach ziarna pyłku były żywe w więcej niż $90 \%$, lecz nie miało to bezpośredniego związku ze zdolnością gametofitów do wytwarzania łagiewek pyłkowych. Potwierdza to wątpliwości innych autorów, którzy, tak jak m.in. Stace [1993], wykazują, że wybarwienie protoplastów nie oznacza jednoznacznie, że gametofit jest zdolny do wytworzenia łagiewki pyłkowej, a to właśnie ten proces jest kluczowy w procesie rozmnażania płciowego roślin.

Badania żywotności pyłku wierzby lapońskiej metodą określania dynamiki kiełkowania w łagiewki pyłkowe były już przeprowadzone m.in. przez Dzwonkowskiego [2011] oraz Pogorzelec i in. [2015]. Dzwonkowski [2011] przeprowadził badania żywotności pyłku wierzby lapońskiej w aspekcie czasu ich przechowywania. Świeży pyłek kiełkowano w dwóch stężeniach glukozy, tj. 2,5\% i 5\%. Materiał roślinny, podobnie jak w przedstawionych $\mathrm{w}$ niniejszej pracy, pobrano $\mathrm{z}$ osobników rosnących nad jeziorem Bikcze. Po 24 h ziarna pyłku z obecną łagiewką pyłkową stanowiły 10,3\%. Wyniki badań prowadzonych w 2019 r. wykazały, że udział ziaren pyłku zdolnych do kiełkowania w łagiewkę pyłkową był znacznie wyższy i wynosił $49 \%$ w pierwszym terminie (T1) i 56\% w drugim terminie (T2).

Porównując kiełkowanie ziaren pyłku dwóch badanych w 2019 r. gatunków (S. lapponum i S. cinerea), zaobserwowano, że materiał zebrany w pierwszym terminie (zdeponowany w 2,5\% roztworze glukozy przez $24 \mathrm{~h}$ ) charakteryzował się tym, że więcej łagiewek wytworzyły gametofity męskie wierzby lapońskiej. Pyłek wierzby szarej zdeponowany w $5 \%$ roztworze glukozy wykazywał znacznie mniejszą zdolność do wytwarzania łagiewek niż pyłek ten w 2,5\% roztworze glukozy. Może to sugerować, że w przypadku tego gatunku stworzeniu optymalnych warunków przebiegu opisanego procesu sprzyja niższa zawartość cukrów w pożywce.

Wyniki analiz żywotności gametofitów męskich pobranych w drugim terminie (T2) jednoznacznie wskazują na większą zdolność wytwarzania łagiewek przez pyłki S. lapponum. 
Porównanie wyników analiz żywotności pyłku S. lapponum i S. cinerea przeprowadzonych w 2019 r. nie wskazują jednoznacznie na możliwość krzyżowania się tych dwóch gatunków na badanym terenie ze względu na różnice w zdolności do wytwarzania przez nie łagiewek pyłkowych. Nie można jednak jednoznacznie wykluczyć możliwości zachodzenia tego zjawiska, ponieważ w 2019 r. kwitnienie obu gatunków zbiegało się w czasie.

Obserwacje prowadzone w roku 2019 powinny być kontynuowane, ponieważ mogą dostarczyć ważnych informacji na temat wpływu warunków termicznych na kwitnienie różnych gatunków wierzb oraz wyjaśnić znaczenie zmian warunków pogodowych dla ewentualnego występowania lub braku w danym roku zjawiska izolacji fenologicznej w stanowiskach zagrożonych gatunków z rodziny Salicaceae.

\section{Bibliografia}

Bolliger, Erben, Grau, Heubl, 1998. Leksykon przyrodniczy. Krzewy. Świat Książki, Warszawa.

Dzwonkowski Ł., 2011. Żywotność i zdolność kiełkowania ziaren pyłku reliktu borealnego Salix lapponum (wierzby lapońskiej) w aspekcie czasu ich przechowywania, praca inż. maszynopis w Kat. Hydrobiologii i Ochrony Ekosystemów UP w Lublinie.

Głębocka K., Pogorzelec M., 2017. Genetic diversity of the Salix lapponum L. population intended as a source of material for reintroduction. Dendrobiology 78, 136-145.

Hroneš M., 2018. Downy willow (Salix lapponum L.) in Central Europe: biosystematics and ecology, Olomouc.

Kaźmierczakowa R., Zarzycki K., Mirek Z. red., 2014. Polska czerwona księga roślin: paprotniki i rośliny kwiatowe: pteridophyta and spermatophyta $=$ Polish plant red data book, wyd. III, Inst. Ochrony Przyrody, PAN, Kraków.

Piękoś-Mirkowa H., Mirek Z., 2018. Flora Polski. Atlas roślin chronionych., wyd. III, MULTICO Ofic. Wyd., Warszawa.

Pogorzelec M., Banach-Albińska B., Serafin A., Szczurowska A., 2014. Population resources of an endangered species Salix lapponum L. in Polesie Lubelskie region [eastern poland]. Acta Agrobot. 67, 4.

Pogorzelec M., Głębocka K., Hawrylak-Nowak B., Bronowicka-Mielniczuk U., 2015. Assessment of chosen reproductive cycle processes and genetic diversity of Salix myrtilloides L. in wetlands of Polesie Lubelskie: the prospects of its survival in the region. Pol. J. Ecology, 63. 291-303.

Pogorzelec M., Parzymies M., Bronowicka-Mielniczuk U., Banach B., Serafin A., 2015. Pollen viability and tissue culture initiation of Salix lapponum, an endangered species in Poland. Acta Sci. Pol. Hortorum Cultus, 14, 6, 151-161.

Rutkowski L., 1998. Klucz do oznaczania roślin naczyniowych Polski niżowej. p. 82.

Serafin A., Pogorzelec M., Banach B., Szczurowska A., Mielniczuk J., 2015. Physico-chemical groundwater conditions at Salix lapponum stands in Eastern Poland. Dendrobiology 73, 65-74.

Stace C.A., 1993. Taksonomia roślin i biosystematyka, Wyd. Nauk. PWN, Warszawa.

Zarzycki K., Trzcińska-Tacik H., Różański W., Szeląg Z., Wołek J., Korzeniak U., 2003. Ekologiczne liczby wskaźnikowe roślin naczyniowych, Instytut Botaniki PAN, Kraków. 


$$
\begin{gathered}
\text { Kamila Talarek } \mathbb{D}^{1,2,3}, \begin{array}{c}
\text { Aleksandra Horbowicz } \mathbb{D}^{1,2} \\
\text { Małgorzata Marczak }
\end{array} \mathbb{D}^{1} \text {, Marceli Romańczuk } \mathbb{D}^{1} \text {, }
\end{gathered}
$$

\section{Charakterystyka wybranych mechanizmów regulacyjnych fizjologii bakterii z uwzględnieniem ich wpływu na tworzenie biofilmów}

Characteristics of selected regulatory mechanisms of bacterial physiology, including their influence on the biofilm formation

Podstawowym warunkiem przetrwania bakterii w środowisku bytowania jest ich zdolność do odbierania sygnałów ze środowiska i umiejętność szybkiego reagowania. Bakterie, narażone na zmiany warunków życia związane ze zmianą dostępności składników pokarmowych, zmianami $\mathrm{pH}$ środowiska czy osmolarności, wykształciły szereg mechanizmów, które pozwalają im na reagowanie na warunki stresowe i adaptację. Jednym z nich jest fosforylacja białek. Kinazy białkowe i ich pokrewne fosfatazy biora udział $w$ transdukcji sygnału poprzez katalizowanie odwracalnej reakcji fosforylacji [Pereira $i$ in. 2011]. Kinazy białkowe odgrywają kluczową rolę w funkcjonowaniu licznie występujących u bakterii systemów dwuskładnikowych (TCS, ang. two-component system), odpowiedzialnych za regulację wielu procesów fizjologicznych. Innymi ważnymi dla bakterii mechanizmami nieopartymi na modyfikacjach potranslacyjnych (PTM, ang. post-translational modification) są wtórne przekaźniki. Najlepiej scharakteryzowane są przekaźniki o charakterze cyklicznych nukleotydów, takie jak cykliczny di-GMP, oraz alarmon odpowiedzi ścisłej (p)ppGpp. W niniejszym opracowaniu przedstawimy wybrane mechanizmy regulacyjne $\mathrm{z}$ zaznaczeniem ich wpływu na wydzielanie polisacharydów zewnątrzkomórkowych i tworzenie biofilmów.

\section{Fosforylacja bialek}

Fosforylacja białek jest jedną z najważniejszych i najczęstszych kowalencyjnych modyfikacji potranslacyjnych. Reakcja przyłączania grupy fosforanowej do reszt aminokwasowych katalizowana jest przez specyficzne kinazy białkowe [Whitmore i Lamont 2012]. Najczęściej występującymi akceptorami dla grup fosforanowych są aminokwasy takie jak seryna, treonina i tyrozyna. Wiązania estrowe wytworzone pomiędzy tymi aminokwasami a fosforem sa stabilne termodynamicznie $\mathrm{w}$ porównaniu $\mathrm{z}$ wiązaniami fosforoamidowymi tworzonymi z udziałem histydyny [Teague i Dobson 1999]. Przez długi czas mechanizmy regulacyjne obejmujące fosforylację Ser/Thr/Tyr opisywano jedynie dla komórek eukariotycznych, zaś w bakteriach zidentyfikowano i opisano kinazy

${ }^{1}$ Uniwersytet Marii Curie-Skłodowskiej, Lublin, Wydział Biologii i Biotechnologii, Instytut Nauk Biologicznych, Katedra Genetyki i Mikrobiologii

${ }^{2}$ Uniwersytet Marii Curie-Skłodowskiej, Lublin, Szkoła Doktorska Nauk Ścisłych i Przyrodniczych

${ }^{3}$ kamila.talarek@umcs.pl 
specyficzne dla histydyny oraz kwasu asparaginowego, które wchodziły w skład regulacyjnych systemów dwuskładnikowych. Pierwszą bakteryjną Ser/Thr kinazę białkową zależną od cAMP opisano dla Escherichia coli [Kuo i Greengard 1969].

Najpowszechniej występującym w bakteriach typem tyrozynowej kinazy białkowej są tzw. BY-kinazy (ang. bacterial tyrosine kinase). Są one zdolne do wiązania ATP i przenoszenia fosforanu na grupę hydroksylową tyrozyny, a w ich sekwencji aminokwasowej możemy wyróżnić motywy Walkera A i B charakterystyczne dla białek wiążących nukleotydy. U Proteobakterii BY-kinazy są białkami błonowymi, z dużą pętlą peryplazmatyczną oraz cytozolową domeną katalityczną [Grangeasse i in. 2007]. Kinazy BY bakterii typu Firmicutes, których modelowym przedstawicielem jest Bacillus subtilis, występują w postaci dwóch odrębnych białek: cytoplazmatycznego, które oddziałuje z białkiem błonowym wykazującym homologię do zewnątrz-cytoplazmatycznej domeny kinaz Proteobakterii. Autofosforylacja białka błonowego jest niezbędna do aktywacji kinazy cytoplazmatycznej. Geny kodujące obydwa białka sąsiadują ze sobą w genomie [Mijakovic i in. 2003].

BY-kinazy odgrywają niezwykle ważną rolę w regulacji fizjologii bakterii, w tym biosyntezy polisacharydów. Znaczna część zidentyfikowanych genów kodujących te białka zlokalizowana jest $\mathrm{w}$ regionach grupujących geny związane $\mathrm{z}$ biosyntezą polisacharydów otoczkowych oraz egzopolisacharydów (EPS). Przykładem takiego enzymu jest BY-kinaza PtkB (EpsB) B. subtilis, która poprzez fosforylację aktywuje glikozylotransferazę EpsE, kodowaną w tym samym regionie [Elsholz i in. 2014].

Innym rodzajem kinaz białkowych występujących u bakterii są eSTK-kinazy (ang. eukariotic-like serine/threonine kinase), które wykazują podobieństwo strukturalne do kinaz eukariotycznych. Wraz ze współdziałającymi z nimi fosfatazami zaangażowane są w kontrolę takich procesów fizjologicznych, jak biosynteza ściany komórkowej, podział komórek, odpowiedź na stres czy tworzenie biofilmu [Hanks i Hunter 1995].

Szeroko rozpowszechnionym w bakteriach systemem regulacji aktywności białek jest dwuskładnikowy system transdukcji sygnału [Hoch 2000]. Typowe systemy dwuskładnikowe zbudowane są z dwóch elementów: błonowego białka sensorowego, które jest kinazą histydynową (HK - ang. histidine kinase) oraz cytoplazmatycznego białka regulatorowego (RR - ang. response regulator). Kinaza zbudowana jest z sensorowej części błonowej oraz transmisyjnej części cytoplazmatycznej zawierającej resztę histydyny. Białko regulatorowe zawiera na $\mathrm{N}$-końcu domenę z resztą kwasu asparaginowego, która ulega fosforylacji resztą pochodzącą $\mathrm{z}$ histydyny białka sensorowego. Kaskada sygnałowa przenoszona jest poprzez domenę efektorową zlokalizowaną w C-końcu, która odpowiedzialna jest za wiązanie DNA, RNA, białek i enzymów [Gao i in. 2007]. Działanie systemów dwuskładnikowych polega indukowanej sygnałem autofosforylacji kinazy histydynowej, przeniesieniu fosforanu na resztę kwasu asparaginowego białka regulatorowego, co wpływa na jego aktywność i pośredniczy w odpowiedzi wyjściowej [Gao i in. 2007]. Systemy dwuskładnikowe pozwalają bakteriom na dostosowywanie się do aktualnie panujących warunków środowiskowych, takich jak dostępność składników odżywczych, pH, temperatura czy osmolarność [Lipa i Janczarek 2020]. Analiza sekwencji genomów bakteryjnych wskazuje na dużą złożoność i zmienność TCS, ze względu na różnorodne sygnały odbierane ze środowiska zewnętrznego [Zschiedrich i in. 2016]. 


\section{Cykliczne di-GMP}

Cykliczne nukleotydy (CDNs - ang. cyclic dinucleotides) to wszechobecne cząsteczki sygnałowe, które kontrolują ważne procesy fizjologiczne bakterii. Jednym z najlepiej zbadanych związków z tej rodziny jest cykliczny di-GMP (c-di-GMP). Jego stężenie w komórce zmienia się w zależności od panujących warunków wewnętrznych i zewnętrznych, dzięki aktywności dwóch antagonistycznych enzymów: cyklazy diguanylanowej (DGC - ang. diguanylate cyclase) oraz fosfodiesterazy specyficznej dla c-di-GMP (PDE - ang. phosphodiesterase). Zaproponowano mechanizm biosyntezy, w którym dwie cząsteczki cGMP ustawione są w sposób przeciwległy do siebie, co umożliwia kondensację w c-di-GMP, podczas reakcji katalizowanej przez enzym DGC [Schirmer 2016]. Efektorami regulowanymi przez poziom c-di-GMP mogą być czynniki transkrypcyjne oraz RNA ryboprzełączników, które wpływają na ekspresję genów odpowiednio na poziomie transkrypcyjnym lub potranskrypcyjnym [Hengge 2010]. Regulacja przez c-di-GMP odbywa się również na poziomie potranslacyjnym. Zidentyfikowano i scharakteryzowano kilka rodzin białek efektorowych, do których należą między innymi białka zawierające domeny PilZ wiążące c-di-GMP, związane z syntezą polisacharydów bakteryjnych oraz ruchliwością bakterii [Ryjenkov i in. 2006].

Jedną z najczęściej charakteryzowanych funkcji c-di-GMP jest udział w regulacji przejścia z planktonicznego do osiadłego trybu życia [Valentini i Filloux 2016]. Niski poziom cząsteczki sygnałowej związany jest z ruchliwością komórki bakteryjnej, natomiast wzrost poziomu przekaźnika sprzyja adhezji do powierzchni i tworzeniu biofilmów. W E. coli i Salmonella enterica subsp. enterica serovar Typhimurium podwyższony poziom c-di-GMP powoduje blokowanie funkcji motorycznych, poprzez wiązanie się z białkiem efektorowym YcgR, które oddziałuje z białkami kompleksu przełącznikowego rzęski bakteryjnej [Paul i in. 2010]. Po kontakcie z powierzchnią, następują dalsze zmiany w fizjologii bakterii kontrolowane przez poziom c-di-GMP, m.in. wytwarzaniu pili typu IV, które biorą udział w adhezji oraz produkcji macierzy zewnątrzkomórkowej pełniącej funkcje ochronne. Regulacja tworzenia biofilmu zachodzi na poziomie transkrypcyjnym, translacyjnym oraz potranslacyjnym [Steiner i in. 2013, Park i in. 2015, Kariisa i in. 2016].

Wykazano, że zjadliwość patogenów zwierzęcych i roślinnych również jest modulowana przez c-di-GMP. Procesy takie jak przyleganie do komórki gospodarza, modulacja jego odpowiedzi immunologicznej, odporność na stres oksydacyjny i wydzielanie czynników wirulencji są związane z poziomem tego przekaźnika wtórnego w komórce. Wykazano, że komórki Clostriudium difficile pod wpływem c-di-GMP przechodzą w trakcie zakażenia do trybu osiadłego, w wyniku czego ściśle przylegają do błony śluzowej komórek jelita [Purcell i in. 2012]. Wybuch epidemii zakażeń E. coli O104:H4 w Niemczech w 2011 r. spowodowany był szczepem powodującym zespół hemolityczno-mocznicowy, charakteryzującym się wysokim poziomem produkcji c-di-GMP, co sprzyjało tworzeniu biofilmów i spowodowało znaczny wzrost zjadliwości bakterii [Buchholz i in. 2011].

\section{Alarmon odpowiedzi ścisłej (p)ppGpp}

Tetrafosforan guanozyny i pentafosforan guanozyny, nazywane wspólnie (p)ppGpp, to podobnie jak c-di-GMP wtórne przekaźniki pochodne nukleotydów. Syntetyzowane są poprzez dodanie reszty pirofosforanowej w pozycji 3' do GDP i GTP 
[Pesavento i Hengge 2009]. Pełnią ważną rolę w regulacji fizjologii bakterii w warunkach stresowych i są kluczowym elementem tzw. odpowiedzi ścisłej. W sytuacjach ograniczenia dostępności składników odżywczych (p)ppGpp powoduje spadek tempa podziałów, wiążąc się bezpośrednio z polimerazą RNA i hamując biosyntezę rybosomalnego RNA [Zuo i in. 2013], a tym samym blokując biosyntezę białek w celu przestawienia ogólnego metabolizmu komórki na przetrwanie. Kontroli podlega ekspresja genów biorących udział w biosyntezie aminokwasów i regulacji metabolizmu nukleotydów poprzez bezpośrednie wiązanie się z enzymami zaangażowanymi w ich biosyntezę i pobieranie [Potrykus i Cashel 2008]. Niskie stężenie (p)ppGpp utrzymywane jest w komórce nawet $\mathrm{w}$ optymalnych warunkach, będąc istotnym regulatorem tempa wzrostu bakterii [Potrykus i in. 2011].

$\mathrm{Za}$ regulację wewnątrzkomórkowego stężenia (p)ppGpp odpowiedzialnych jest kilka klas enzymów, głównie syntetazy i hydrolazy. Rodzina dwufunkcyjnych białek RelA-SpoT (RSH - ang. RelA/SpoT homologue) to najlepiej scharakteryzowana grupa odpowiedzialna za syntezę (p)ppGpp z ATP i GTP lub GDP oraz degradację przekaźnika do pirofosforanu i GTP lub GDP. Enzym RelA i jego homologi aktywują się w odpowiedzi na głód aminokwasowy, natomiast SpoT podczas niedoborów kwasów tłuszczowych, żelaza, fosforu oraz węgla [Amiri i in. 2020; Haseltine i Block 1973].

Wykazano, że wtórne przekaźniki (p)ppGpp odgrywają również ważną rolę w tworzeniu biofilmów bakteryjnych, jednakże ten wpływ może różnić się dla różnych gatunków bakterii. Pozytywny wpływ fosforanów guanozyny na tworzenie biofilmów wykazano w przypadku Agrobacterium sp. ATCC 31749, Vibrio cholerae [He i in. 2012] i E. coli [Åberg i in. 2006]. Mutanty Agrobacterium sp. ATCC 31749 pozbawione genu odpowiedzialnego za syntezę alarmonów odpowiedzi ścisłej, nie były w stanie syntetyzować egzopolisacharydu, który wchodzi w skład macierzy biofilmu. Analiza transkryptomu w warunkach niedoboru azotu wykazała, że ekspresja genów homologów RelA-SpoT wzrosła w warunkach stresowych niemal 100 -krotnie w porównaniu z warunkami optymalnymi [Ruffing i Chen 2012]. Odwrotny, negatywny wpływ (p)ppGpp na ilość tworzonych polisacharydów zewnątrzkomórkowych zanotowano dla Actinobacillus pleuropneumoniae [Li i in. 2015] oraz Sinorhizobium meliloti.

\section{Podsumowanie}

Adaptacja komórek bakteryjnych do niekorzystnych warunków jest możliwa dzięki złożonym procesom metabolicznym, które zachodzą w komórce w reakcji na czynnik stresowy. Jednym z mechanizmów adaptacyjnych jest odpowiedź ścisła, zaobserwowana po raz pierwszy w $E$. coli w warunkach niedoboru składników odżywczych, podczas której zachodzi synteza nukleotydów (p)ppGpp. Odbieranie sygnałów środowiskowych i kontrola odpowiedzi komórkowej możliwa jest między innymi dzięki licznie występującymi u bakterii dwuskładnikowymi systemami transdukcji sygnału, których działanie oparte jest na zjawisku odwracalnej fosforylacji z udziałem kinaz i fosfataz białkowych, które autofosforylują, fosforylują i defosforylują odpowiednie efektory komórkowe. Wszystkie wymienione mechanizmy odgrywają istotną rolę w fizjologii bakterii, w tym tworzeniu biofilmów i wirulencji patogenów. Dokładne poznanie takich mechanizmów stwarza szansę na opracowanie nowych leków przeciwbakteryjnych, których działanie opierałoby się na interferencji ze szlakami, które umożliwiają adaptację, adhezję i inwazję. 


\section{Bibliografia}

Åberg A., Shingler V., Balsalobre C., 2006. (p)ppGpp regulates type 1 fimbriation Escherichia coli by modulating the expression of the site-specific recombinase FimB. Molecular Microbiol. 60(6):1520-33, https://doi.org/10.1111/j.1365-2958.2006.05191.x.

Amiri M., Rad A.H.S., Valadabadi A., Sayfzadeh S., Zakerin H., 2020. Response of rapeseed fatty acid composition to foliar application of humic acid under different plant densities. Plant, Soil Environ. 66, 303-308, https://doi.org/10.17221/220/2020-PSE.

Buchholz U., Bernard H., Werber D., Böhmer M.M., Remschmidt C., Wilking H., Deleré Y., an der Heiden M., Adlhoch C., Dreesman J., Ehlers J., Ethelberg S., Faber M., Frank C., Fricke G., Greiner M., Höhle M., Ivarsson S., Jark U., Kühne M., 2011. German Outbreak of Escherichia coli O104:H4 associated with sprouts. New Engl. J. Med. 10, 365(19),1763-70, https://doi.org/10.1056/nejmoa1 106482.

Elsholz A.K.W., Wacker S.A., Losick R., 2014. Self-regulation of exopolysaccharide production in Bacillus subtilis by a tyrosine kinase. Genes and Develop. 28(15), 1710-1720. https://doi.org/10.1101/gad.246397.114.

Gao R., Mack T. R., Stock A.M., 2007. Bacterial response regulators: versatile regulatory strategies from common domains. Trends Biochem. Sci., May, 32(5) 225-34, https://doi.org/10.1016/j.tibs.2007.03.002.

Grangeasse C., Cozzone A.J., Deutscher J., Mijakovic I., 2007. Tyrosine phosphorylation: an emerging regulatory device of bacterial physiology. Trends Biochem. Sci. 32(2), 86-94, https://doi.org/10.1016/j.tibs.2006.12.004.

Hanks S.K., Hunter T., 1995. The eukaryotic protein kinase superfamily: kinase (catalytic) domain structure and classification. FASEB J. 9(8), 576-96, https://doi.org/10.1096/fasebj.9.8.7768349.

Haseltine W.A., Block R., 1973. Synthesis of guanosine tetra and pentaphosphate requires the presence of a codon specific, uncharged transfer ribonucleic acid in the acceptor site of ribosomes. Proc. National Acad. Sci. United States Am. 70(5), 1564-8, https://doi.org/10.1073/pnas.70.5.1564.

He H., Cooper J.N., Mishra A., Raskin D.M., 2012. Stringent response regulation of biofilm formation in Vibrio cholerae. J. Bacteriol. 194(11), 2962-72, https://doi.org/10.1128/JB.00014-12.

Hengge R., 2010. Cyclic-di-GMP reaches out into the bacterial RNA world. Sci. Signal. 23, 3(149), https://doi.org/10.1126/scisignal.3149pe44.

Hoch J.A., 2000. Two-component and phosphorelay signal transduction. Curr. Opinion Microbiol. 3(2), 165-70, https://doi.org/10.1016/S1369-5274(00)00070-9.

Kariisa A.T., Weeks K., Tamayo R., 2016. The RNA Domain Vc1 regulates downstream gene expression in response to cyclic diguanylate in Vibrio cholerae. PLoS ONE 5, 11(2) https://doi.org/10.1371/journal.pone.0148478.

Kuo J.F., Greengard P., 1969. An Adenosine 3',5'-Monophosphate-dependent Protein Kinase from Escherichia coli. J. Biol. Chem. 244(12), 3417-3419. https://doi.org/10.1016/S00219258(18)97782-3.

Li G., Xie F., Zhang Y., Bossé J.T., Langford P.R., Wang C., 2015. Role of (p)ppGpp in viability and biofilm formation of Actinobacillus pleuropneumoniae S8. PLoS ONE 10(10) https://doi.org/10.1371/journal.pone.0141501.

Lipa P., Janczarek M., 2020. Phosphorylation systems in symbiotic nitrogen-fixing bacteria and their role in bacterial adaptation to various environmental stresses. PeerJ 11, 8 https://doi.org/10.7717/peerj.8466.

Mijakovic I., Poncet S., Boël G., Mazé A., Gillet S., Jamet E., Decottignies P., Grangeasse C., Doublet P., Le Maréchal P., Deutscher J., 2003. Transmembrane modulator-dependent bacterial tyrosine kinase activates UDP-glucose dehydrogenases. EMBO J. 22(18), 4709-4718, https://doi.org/10.1093/emboj/cdg458.

Park J.H., Jo Y., Jang S.Y., Kwon H., Irie Y., Parsek M.R., Kim M.H., Choi S.H., 2015. The cabABC Operon Essential for Biofilm and Rugose Colony Development in Vibrio vulnificus. PLoS Pathogens 11(9), https://doi.org/10.1371/journal.ppat.1005192. 
Paul K., Nieto V., Carlquist W.C., Blair D.F., Harshey R.M., 2010. The c-di-GMP Binding Protein YcgR Controls Flagellar Motor Direction and Speed to Affect Chemotaxis by a „Backstop Brake” Mechanism. Molec. Cell 9, 38(1), 128-39, https://doi.org/10.1016/j.molcel.2010.03.001.

Pereira S.F.F., Goss L., Dworkin J., 2011. Eukaryote-Like Serine/Threonine Kinases and Phosphatases in Bacteria. Microbiol. Molec. Biol. Rev. 75(1), 192-212. https://doi.org/10.1128/mmbr.00042-10.

Pesavento C., Hengge R., 2009. Bacterial nucleotide-based second messengers. Curr. Opinion Microbiol. 12(2), 170-176, https://doi.org/10.1016/j.mib.2009.01.007.

Potrykus K., Cashel M., 2008. (p)ppGpp: Still magical? Ann. Rev. Microbiol. 62, 35-51, https://doi.org/10.1146/annurev.micro.62.081307.162903.

Potrykus K., Murphy H., Philippe N., Cashel M., 2011. ppGpp is the major source of growth rate control in E. coli. Environ. Microbiol. 13(3), 563-575, https://doi.org/10.1111/j.14622920.2010.02357.x.

Purcell E.B., McKee R.W., McBride S.M., Waters C.M., Tamayo R., 2012. Cyclic diguanylate inversely regulates motility and aggregation in Clostridium difficile. J. Bacteriol. 94(13), 3307-16, https://doi.org/10.1128/JB.00100-12.

Ruffing A.M., Chen R.R., 2012. Transcriptome profiling of a curdlan-producing Agrobacterium reveals conserved regulatory mechanisms of exopolysaccharide biosynthesis. Microbial Cell. Factor. 3, 11-17 https://doi.org/10.1186/1475-2859-11-17.

Ryjenkov D.A., Simm R., Römling U., Gomelsky M., 2006. The PilZ domain is a receptor for the second messenger c-di-GMP: The PilZ domain protein $\mathrm{YcgR}$ controls motility in enterobacteria. J. Biol. Chem. 13, 281(41), 30310-30314, https://doi.org/10.1074/jbc.C600179200.

Schirmer T.. 2016. C-di-GMP Synthesis: Structural Aspects of Evolution, Catalysis and Regulation. J. Molec. Biol. 428(19), 683-370, https://doi.org/10.1016/j.jmb.2016.07.023.

Steiner S., Lori C., Boehm A., Jenal U., 2013. Allosteric activation of exopolysaccharide synthesis through cyclic di-GMP-stimulated protein-protein interaction. EMBO J. 32(3), 354-68, https://doi.org/10.1038/emboj.2012.315.

Teague W.E., Dobson G.P., 1999. Thermodynamics of the arginine kinase reaction. J. Biol. Chem. 32(3), 354-68, https://doi.org/10.1074/jbc.274.32.22459.

Valentini M., Filloux A., 2016. Biofilms and Cyclic di-GMP (c-di-GMP) signaling: Lessons from Pseudomonas aeruginosa and other bacteria. J. Biol. Chem. 291(24), 12547-12555, https://doi.org/10.1074/jbc.R115.711507.

Whitmore S.E., Lamont R.J., 2012. Tyrosine phosphorylation and bacterial virulence. Intern. J. Oral Sci. 4(1), 1-6, https://doi.org/10.1038/ijos.2012.6.

Zschiedrich C.P., Keidel,V., Szurmant H., 2016. Molecular Mechanisms of Two-Component Signal Transduction. J. Molec. Biol. 428(19), 3752-75, https://doi.org/10.1016/j.jmb.2016.08.003.

Zuo Y., Wang Y., Steitz T.A., 2013. The Mechanism of E. coli RNA Polymerase Regulation by ppGpp is suggested by the structure of their complex. Molec. Cell 50(3), 430-436, https://doi.org/10.1016/j.molcel.2013.03.020. 
Urszula Waszczuk $^{1,2}$, Ewa Zapora ${ }^{1,3}$

\section{Grzyby wielkoowocnikowe w ochronie środowiska naturalnego}

Macromycetes in environmental protection

Grzyby wielkoowocnikowe (Macromycetes) zwane również „grzybami wyższymi” lub makroskopijnymi to zróżnicowana grupa grzybów, do których zalicza się grzyby podstawkowe (Basidiomycetes) i workowe (Ascomycetes), a ich owocniki są dla obserwatora widoczne gołym okiem [Chang i Miles 2004]. Basidiomycetes rosną i rozwijają się w drewnie drzew i krzewów zarówno tych żywych, jak i osłabionych i zamierających, a także martwych stojących i leżących, zasiedlających także surowiec okrągły i drewno przerobione [Szczepkowski 2012]. Rozmnażają się one płciowo, wytwarzając zarodniki na charakterystycznej komórce, zwanej podstawką (basidium) [Miettinen 2011]. W przypadku Ascomycetes zarodniki rozwijają się w zarodni podobnej kształtem do worka (acus). Do grzybów wielkoowocnikowych zalicza się także grzyby poliporoidalne, niebędące grupą systematyczną a morfologiczną. Ich wyróżnikiem jest hymenofor zawierający rurki, których zakończeniem są widoczne na owocnikach pory (-poroidalne), występujące w dużej ilości (poli-) [Miettinen 2011].

Grzyby wielkoowocnikowe odżywiają się poprzez enzymatyczny rozkład substancji, które pobierają, wrastając w głąb substratu [Domański i in. 1967], czego widocznym efektem jest zgnilizna drewna [Domański i in. 1967, Szczepkowski 2012]. W zależności od tego, jaki składnik drewna (celuloza, hemiceluloza lub lignina) jest rozkładany, powstają różne rodzaje zgnilizn. Najczęściej występuje zgnilizna biała oraz brunatna [Domański i in. 1967]. Grzyby rozkładające martwe drewno, a zwłaszcza te powodujące białą zgniliznę drewna, ze względu na syntezę szeregu związków biologicznie aktywnych budzą coraz większe zainteresowanie naukowców [Chang i Miles 2004, Zjawiony 2004, Alves i in. 2013].

\section{Wykorzystanie grzybów wielkoowocnikowych w ochronie środowiska naturalnego}

\section{Ochrona biologiczna przed fitopatogenami}

Kontrola biologiczna to sposób ochrony ekosystemów przed szkodliwymi patogenami. Może być prowadzona przy użyciu środków i biopestycydów, m.in. przy współudziale mikroorganizmów oraz ich produktów przemiany materii [Spremo 2017]. Intensywne stosowanie syntetycznych fungicydów w walce $\mathrm{z}$ fitopatogenami wywołuje znaczne obawy, głównie ze względu na toksyczność oraz rakotwórczość występujących w nich związków chemicznych. Ma to znaczenie, zwłaszcza w badaniach nad nowymi organicznymi fungicydami na bazie ekstraktów z grzybów, które mogą być formą kontroli biologicz-

\footnotetext{
${ }^{1}$ Politechnika Białostocka, Wydział Budownictwa i Nauk o Środowisku, Instytut Nauk Leśnych

${ }^{2}$ u.waszczuk@pb.edu.pl

${ }^{3}$ e.zapora@pb.edu.pl
} 
nej [Spremo 2017]. Kluczową rolę odgrywają w tym zakresie kwasy fenolowe, m.in. kwas kawowy, ferulowy, p-kumarowy, o-kumarowy, p-hydroksybenzoesowy, syringinowy, wanilinowy, występujące powszechnie zarówno w tkankach roślin, jak i w glebie [Gałązka 2013]. Wykazują one silną aktywność biologiczną, a ich obecność wiąże się z nabyciem przez roślinę odporności. W związku z powyższym biopreparaty indukujące odporność roślin przed fitopatogenami mogą być oparte na ekstraktach z grzybów wielkoowocnikowych zawierających w swoim składzie związki fenolowe. Grzyby Ascomycetes i Basidiomycetes, wytwarzające egzopolisacharydy (EPS), mogą pomagać roślinom $\mathrm{w}$ ochronie przed stresem środowiskowym lub niepożądanymi interakcjami $\mathrm{z}$ innymi organizmami. Badania potwierdzają ich zdolność do indukowania odporności roślin [Tamm i in. 2011].

\section{Mykoremediacja}

Mykoremediacja jest odmianą bioremediacji, w której do poprawy stanu środowiska wykorzystuje się technologie oparte na aktywności degradacyjnej grzybów. Niektóre grzyby białej zgnilizny są w stanie jednocześnie degradować ligninę, celulozę $\mathrm{i}$ hemicelulozy, podczas gdy inne atakują ligninę selektywnie przez wydzielanie enzymów, zwanych łącznie „ligninazami” [Zerva i in. 2021]. Oprócz enzymów ligninolitycznych wydzielają one także celulazy, ksylanazy i inne hemicelulazy [Zerva $i$ in. 2021]. Badania potwierdzają, iż preparaty na bazie kompleksów enzymatycznych (dioksygenazy, reduktazy, dehalogenazy, monooksygenazy cytochromu P450, lakazy, peroksydazy ligninowe, peroksydazy manganu, transferaza glutationu, hydrolaza epoksydowa) lub biokatalizatorów mogą być wykorzystane do zmniejszenia szkodliwości danych zanieczyszczeń, m.in. wielopierścieniowych węglowodorów aromatycznych (WWA), fenoli, insektycydów chloroorganicznych, pestycydów fosforoorganicznych, fungicydów, barwników syntetycznych, mykotoksyn, a nawet do ich całkowitego zneutralizowania [Pieper i in. 2004, Ramos i in. 2005, Alcade i in. 2006, Akhtar i Amin-ul Mannan 2020]. Dodatkowo w porównaniu z innymi metodami ochrony środowiska, zastosowanie preparatów z lakazą daje możliwość rozkładu dużo szerszej gamy zanieczyszczeń trudno biodegradowalnych, takich jak: węglowodory aromatyczne i alifatyczne, chlorowane związki organiczne, barwniki, pozostałości materiałów wybuchowych, antybiotyki, ropa naftowa, olej napędowy [Reddy i Mathew 2001, Hou i Ma 2007, Vigueras i in. 2008, Tiso i in. 2015, Ghosal i in. 2016]. Według Zerva i in. [2021]. Grzyby z gatunków: Pleurotus citrinopileatus, Abortiporus biennis, Ganoderma resinaceum były w stanie usunąc $80 \%$ zanieczyszczeń spowodowanych przez produkty uboczne przemysłu i rolnictwa (fenole, DPPH (2,2-difenylo-1-pikrylo-hydrazyl), ścieki z olejarni). Przyjazna środowisku mykoremediacja może być więc jedynym rozwiązaniem do usuwania trudno degradowalnych zanieczyszczeń.

\section{Mykoremediacja wód}

Spośród grzybów wielkoowocnikowych zdolność biodegradacji w wodzie wykazują grzyby białej i brunatnej zgnilizny drewna należące do takich gatunków, jak Phanerochaete chrysosporium, Trametes versicolor, Pleurotus ostreatus, Funalia trogii, Phlebia tremellosa, Irpex lacteus, Dichomitus squalens czy Bjerkandera adusta [Jarosz-Wilkołazka 2002, Przystaś i in. 2013, Rybczyńska i Korniłłowicz-Kowalska 2015]. Strzępki grzybni Pleurotus ostreatus są w stanie usunąć metale ciężkie, takie jak ołów, cynk, chrom, kobalt, miedź i nikiel obecne w ściekach [Vaseem i in. 2017]. Co więcej 
według Purnomo i in. [2017] dzięki reakcji enzymów epoksydowych i hydroksylacji $P$. ostreatus potrafi neutralizować także aldrynę (silnie trujący składnik wielu insektycydów). Trametes versicolor neutralizuje cyjanotoksyny i hamuje zakwit glonów [Du i in. 2015, Gao i in. 2017, Dai i in. 2018]. Oprócz grzybów poliporoidalnych istotne znaczenie w remediacji ścieków mają także grzyby Ascomycetes, które dzięki zdolności adsorpcji z łatwością usuwają z wód szkodliwe barwniki [Verma i in. 2010]. Badacze udowodnili natychmiastowe działanie remediacyjne workowców i podstawczaków, które usunęły razem $80 \%$ mieszaniny barwników ze ścieków w 6 dni, a także całkowicie wyeliminowały z wody fenole. Skuteczność badań była tak duża, że naukowcy przewidują możliwość stosowania tych grzybów w ochronie wód na skalę przemysłową [Verma i in. 2010].

\section{Mykoremediacja gleb}

Obok metali ciężkich i radionuklidów grzyby są zdolne do degradacji wielopierścieniowych węglowodorów aromatycznych (WWA) [Wang i in. 2016]. Badania wykazały, że przydatny w eliminacji WWA z gleby może być kompost pogrzybowy pochodzący z produkcji pieczarek dwuzarodnikowych (Agaricus bisporus) i grzybów shiitake (Lentinula edodes) [Wang i in. 2016]. Inne badania potwierdzają również, że grzyby białej zgnilizny drewna należące do rodzajów Phanerochaete, Polyporus, Stereum, Lentinus, Bjerkandera, Irpex, Pleurotus, Phlebia oraz Trametes, Schizophyllum, Pycnoporus, Coprinus czy Ganoderma [Matsubara i in. 2006, Rodrigues-Couto 2017] biorą także aktywny udział w rozkładzie WWA, głównie dzięki takim enzymom jak lakaza, nadoksydaza ligniny i peroksydaza manganowa [Bhattacharya i in. 2014]. Biorą także bezpośredni udział w biodegradacji benzenu, toluenu czy styrenu [Vigueras i in. 2008]. Niektóre z grzybów należących do rodzajów Bjerkandera, Anthracophyllum, Phanerochaete, Trametes dzięki enzymymom lignolitycznym, estryfikacji, dioksygenacji, dehydrogenacji są zdolne do neutralizacji polichlorofenoli, częstego występujących w fungicydach, herbicydach i insektycydach [Zeng $\mathrm{i}$ in. 2008]. Inne badania potwierdziły, że popularny fungicyd trójbromofenol (TBP), stosowany do konserwacji drewna, może być skutecznie neutralizowany przez Trametes versicolor i Agaricus augustus [Monrroy i in. 2006]. Te dwa grzyby potrafią skutecznie zmniejszać zawartość TBP, przeprowadzając proces biotransformacji do odpowiednich metabolitów, takich jak trójbromoanizol (TBA). Inne grzyby stosowane do degradacji TBP to Laetoporeus sulfureus, Gloeophyllum trabeum i Ganoderma australe [Monrroy i in. 2006].

\section{Mykoremediacja powietrza}

Stale rosnąca liczba ludności, szybkie tempo urbanizacji i industrializacja przyczyniają się do wzrostu zanieczyszczenia powietrza. Ma to negatywny wpływ nie tylko na życie i zdrowie człowieka, ale także na wiele ekosystemów naturalnych. Do najważniejszych zanieczyszczeń powietrza należą: dwutlenek siarki $\left(\mathrm{SO}_{2}\right)$, tlenki azotu $\left(\mathrm{NO}_{\mathrm{x}}\right)$, pyły węglowe, lotne związki organiczne (LZO), tlenek węgla (CO), dwutlenek węgla $\left(\mathrm{CO}_{2}\right)$, ozon troposferyczny $\left(\mathrm{O}_{3}\right)$, ołów $(\mathrm{Pb})$ i pyły zawieszone [Kostrz i Satora 2017]. Szczególnie niebezpieczne są wielopierścieniowe węglowodory aromatyczne (WWA). Grzyby mogą stanowić podstawę do budowy innowacyjnych biofiltrów. Wykonuje się je ze szczepu danego gatunku grzyba, materiału organicznego (np. kompostu czy torfu) lub niedegradowalnego (np. pianki poliuretanowej, perlitu, wermikulitu, kształtki z materiałów syntetycznych), fazy wodnej (nieruchomej lub recyrkulowanej) zawierającej substancje biogenne do odżywienia szczepu i jego nawodnienia [Devinny i in. 1999, Revah i in. 2005, Kołwzan i in. 2018]. Zasada działania biofiltrów polega na tym, że związki che- 
miczne obecne w oczyszczanych gazach przenikają do fazy ciekłej, w której znajduje się szczep danego grzyba, a następnie do wnętrza komórek grzybowych, gdzie stają się substratem pokarmowym. Dalej zanieczyszczenia są usuwane przez grzyby poprzez przekształcenie ich w związki mniej toksyczne i bezzapachowe [Revah i in. 2011]. Grzyby wykorzystywane są również do oczyszczania gazów z organicznych związków hydrofobowych zarówno aromatycznych, jak i alifatycznych, a także cyklicznych monoterpenów [Devinny i in. 1999]. Badanie Esteves i in. [2004] dowodzą, że skutecznym biofiltrem zanieczyszczeń powietrza, a dokładniej szkodliwego toluenu, są grzyby z gatunków Exophiala oligosperma oraz Scedosporium apiospermum.

\section{Podsumowanie}

Badania nad wykorzystaniem grzybów przeżywają swoisty renesans, gdyż obecnie stosowane substancje syntetyczne nie są w stanie rozwiązać wielu problemów. Jako naturalny rezerwuar substancji biologicznie aktywnych są na szczycie zainteresowania naukowców $\mathrm{z}$ różnych dziedzin. Pomimo poznania tak ogromnej liczby gatunków, wiele z nich wciąż pozostaje nieodkrytych dla nauki lub też nie są zdefiniowanie ich właściwości.

Badania nad grzybami wielkoowocnikowymi są szczególnie ważne w zakresie identyfikacji substancji biologicznie aktywnych o potencjalnym działaniu remediacyjnym w ochronie środowiska. Grzyby wielkoowocnikowe to potencjalnie skuteczne środki remediacyjne, mogące stanowić podstawę do nowych, multifunkcyjnych preparatów stosowanych w biokontroli oraz przyczyniających się do przywrócenia równowagi w środowisku naturalnym.

\section{Bibliografia}

Akhtar N., Amin-ul Mannan M., 2020. Mycoremediation: Expunging environmental pollutants. Biotechnol. Rep. 26, https://doi.org/10.1016/j.btre.2020.e00452.

Alcade M., Ferrer M., Plou F.J., Ballesteros A., 2006. Environmental biocatalysis: from remediation with enzymes to novel green processes. Trends Biotechnol. 24, 281-287.

Alves M.J., Ferreira I.C.F.R., Dias J., Teixeira V., Martins A., Pintado M.R.B., 2013. A review on Antifungal Acitvity of Mushroom (Basidiomycetes) Extracts and Isolated Compounds. Curr. Top. Med. Chem. 13, 2648-2659.

Bhattacharya S., Das A., Prashanthi K., Palaniswamy M., Angayarkanni J., 2014. Mycoremediation of Benzo[a]pyrene by Pleurotus ostreatus in the presence of heavy metals and mediators. Biotechnology 4, 205-211, https://doi.org/10.1007/s13205-013-0148-y.

Chang S.T., Miles P.G., 2004. Mushrooms: Cultivation, Nutritional Value, Medicinal Effect and Environmental Impact. Second Edition CRC Press, Boca Raton, Fla. 480.

Dai W., Chen X., Wang X., Xu Z., Gao X., Jiang C., Deng R., Han G., 2018. The algicidal fungus Trametes versicolor $\mathrm{F} 21$ a eliminating blue algae via genes encoding degradation enzymes and metabolic pathways revealed by transcriptomic analysis. Front. Microbiol. 9, https://doi.org/10.3389/fmicb.2018.00826.

Devinny J.S., Deshusses M.A., Webster T.S., 1999. Biofiltration for Air Pollution Control. CRC Press, Boca Raton.

Domański S., Orłoś H., Skirgiełło A., 1967. Flora Polska. Grzyby (Mycota). Tom III. Żagwiowate II (Polyporaceae pileatae), Szczeciniakowate II (Mucronoporaceae pileatae), Lakownicowate (Ganodermataceae), Bondarcewowate (Bondarzewiaceae). Boletkowate (Boletopsidaceae), Ozorkowate (Fistulinaceae). PWN. Warszawa. 
Du J., Pu G., Shao C., Cheng S., Cai J., Zhou L., Jia Y., Tian X., 2015. Potential of extracellular enzymes from Trametes versicolor F21a in Microcystis spp. Degradation. Mater. Sci. Eng. C, 48, 138-144, https://doi/org/10.1016/j.msec.2014.11.004.

Esteves E., Veiga M.C., Kennes C., 2004. Fungal biodegradation of toluene in gas-phase biofilters. In: W. Verstraete [ed.]: European Symposium on Environmental Biotechnology, Taylor \& Francis Group, London, 337-340.

Gałązka A., 2013. Przemiany związków fenolowych a rola amoniakoliazy L-fenyloalaninowej (PAL) w indukcji mechanizmów obronnych rośliny, Pol. J. Agron. 15, 83-88.

Gao X., Wang C., Dai W., Ren S., Tao F., He X., Han G., Wang W., 2017. Proteomic analysis reveals large amounts of decomposition enzymes and major metabolic pathways involved in algicidal process of Trametes versicolor F21a. Sci. Rep. 7, https://doi.org/10.1038/s41598017-04251-1.

Ghosal D., Ghosh S., Dutta T.K., Ahn Y., 2016. Current state of knowledge in microbial degradation of polycyclic aromatic hydrocarbons (PAHs): A review. Front. Microbiol., 7, Art. 1369.

Hou C., Ma G., 2007. Performance experiment on aerobic biodegradation of benzene, toluene and xylene by fungus Trichoderma viridae Pers. ex Fr. Huanjing Gongcheng 25(3), 45-47.

Jarosz-Wilkołazka A., Kochmańska-Rdest J., Makarczyk E., Wardas W., Leonowicz A., 2002. Fungi and their ability to decolourize azo and anthraquinonic dyes. Enzyme Microbial. Technol. 30, 566-572.

Kołwzan B., Adamiak W., Dziubek A.M., 2018. Możliwości zastosowania grzybów w technologiach oczyszczania i remediacji wybranych elementów środowiska. Ochrona Środ. 40(1), 3-20.

Kostrz M., Satora P., 2017. Związki odpowiedzialne za oczyszczanie powietrza. Inż. Ekol. 18(6), 89-95, https://doi.org/10.12912/23920629/79820.

Matsubara M., Lynch J., de Leij F.A.A.M., 2006. A simple screening procedure for selecting fungi with potential for use in the bioremediation of contaminated land. Enzyme Microbial. Technol. 39(7), 1365-1372.

Miettinen O., 2011 Taxonomy and phylogeny of white-rot polypores: case studies in Hymenochaetales and Polyporales (Basidiomycota). Uniw. Helsiński. Helsinki.

Monrroy M., Freer J., Baeza J., Rodriguez J., 2006. Degradation of tribromophenol by wood-rot fungi and Hamilton system. Electr. J. Biotechnol. 9(3), 253-257.

Pieper D.H., Martins dos Santos V.A., Golyshin P.N., 2004. Genomic and mechanistic insight into the biodegradation of organic pollutants. Curr. Opinion Biotechnol. 15, 215-224.

Przystaś W., Zabłocka-Godlewska E., Grabińska-Sota E., 2013. Effectiveness of dyes removal by mixed fungal cultures and toxicity of their metabolites. Water, Air Soil Poll.2 24, 1534-1543.

Purnomo A.S., Nawfa R., Martak F., Shimizu K., Kamei I., 2017. Biodegradation of Aldrin and Dieldrin by the white-rot fungus Pleurotus ostreatus. Curr. Microbiol. 74, 320-324, https://org/10.1007/s00284-016-1184-8.

Ramos J.L., Mar González-Pérez M., Caballero A., van Dillewijn P., 2005. Bioremediation of polynitrated aromatic compounds: plants and microbes put up a fight. Curr. Opin. Biotechnol. $16,275-281$.

Reddy C.A., Mathew Z., 2001 Bioremediation potential of white rot fungi. In: G. M. Gadd [Ed.]: Fungi in Bioremediation, Cambridge Univ. Press, Cambridge.

Revah S., Morgan-Sagastume J.M., 2005. In: Shareefdeen Z, Singh A, Eds. Methods for odor and VOC control in Biotechnology for odour and air pollution. Heidelberg: Springer-Verlag, pp. 29-64.

Revah S., Vergara-Fernandes A., Hernandes S., 2011. Fungal biofiltration for the elimination of gaseous pollutants from air. In: A. L. Leitão (Ed.): Mycofactories, Bentham Science Publishers Ltd., 109-120.

Rodriguez-Couto S., 2017. Industrial and environmental application of white-rot fungi. Mycosphere 8(3), 456-466.

Rybczyńska K., Korniłłowicz-Kowalska T., 2015. Evaluation of dye compounds' decolorization capacity of selected $H$. haematococca and $T$. harzianum strains by principal component analysis (PCA). Water, Air, Soil Poll. 226, 228. 
Spremo R.N., Tesanović D.K., Rakić S.M., Janjušević N.J., Ignjatov V.M., Bjelić D.D., Karaman A.M., 2017. Antifungal activity of macrofungi extracts on phytopathogenic fungal genera Fusarium sp. and Alternaria sp. Matica Srpska. J. Nat. Sci. Novi Sad. 133, 231-240, https://doi.org/10.2298/ZMSPN1733231S.

Szczepkowski A., 2012. Grzyby nadrzewne w innym świetle - użytkowanie owocników. Studia i Materiały CEPL w Rogowie, 14. 32/3.

Tamm L., Thürig B., Fliessbach A., Goltlieb A.E., Karavani S., Cohenb Y., 2011. Elicitors and soil management to induce resistance against fungal plant diseases. NJAS Wagen J. Life Sci. 58, 131-137, https://doi.org/10.1016/j.njas.2011.01.001.

Tiso N., Mikasauskaite J., Stankevicius M., Snieskiene V., Stankeviciene A., Polcaro C., Galli E., Donati E., Zacchini M., Levišauskas D., Tekorius T., Ragažinskienè O., Drevinskas T., Bartkuvienè V., Kornyšova O., Kaškonienè V., 2015. Isolation and identification of fungi tolerant to polycyclic aromatic hydrocarbons and coal tar from different habitats in Lithuania. Toxicol. Environ. Chem. 98(1), 77-89.

Vaseem H., Singh V.K., Singh M.P., 2017. Heavy metal pollution due to coal washery effluent and its decontamination using a macrofungus, Pleurotus ostreatus. Ecotoxicol. Environ. Saf. 145, 42-49, https://doi.org/10.1016/j.ecoenv.2017.07.001.

Verma A.K., Raghukumar C., Verma P., Shouche Y.S., Naik C.G., 2010. Four marine-derived fungi for bioremediation of raw texitile mill effluents. Biodegradation 21(2), 217-233.

Vigueras G., Shirai K., Martins D., Franco T.T., Fleuri L.F., Revah S., 2008. Toluene gas phase biofiltration by Paecilomyces lilacinus and isolation and identification of a hydrophobic protein produced thereof. Appl. Microbiol. Biotechnol. 80(1), 147-154.

Wang C., Dong Y., Shi W., Xu H., 2016. Application of spent mushroom (Lentinula edodes) substrate and acclimated sewage sludge on the bioremediation of polycyclic aromatic hydrocarbon polluted soil. RSC Adv. 6(43), 37274-37285.

Zeng B., Ning D.L., Wang H., 2008. Preliminary study on biodegradation of pentachlorophenol by white-rot fungus. Huanjing Huaxue (Environmental Chemistry) 7(2), 181-185.

Zerva A., Tsafantakis N., Topakas E., 2021. Evaluation of Basidiomycetes Wild Strains Grown in Agro-Industrial Residues for Their Anti-Tyrosinase and Antioxidant Potential and for the Production of Biocatalysts. Fermentation 7(19), 1-12, https://doi.org/10.3390/fermentation7010019.

Zjawiony J.K., 2004. Biologically Active Compounds from Aphyllophorales (Polypore) Fungi. J. Nat. Prod. 67(2), 300-310, https://doi.org/10.1021/np030372w. 